UNIVERSIDADE DE SÃO PAULO

FACULDADE DE EDUCAÇÃO

BRIGITTE URSULA STACH-HAERTEL

\title{
A Constituição \\ DE SUBJETIVIDADES LEGITIMADORAS \\ DAS DESIGUALDADES DE GÊNERO: \\ Um estudo a partir de referenciais da \\ Psicologia e Educação
}




\section{A CONSTituição \\ DE SUBJETIVIDADES LEGITIMADORAS \\ DAS DESIGUALDADES DE GÊNERO: \\ Um estudo a partir de referenciais da \\ Psicologia e Educação}

Dissertação apresentada à Faculdade de Educação da Universidade de São Paulo como parte dos requisitos para a obtenção do título de Mestre em Psicologia e Educação.

Área de concentração: Psicologia e Educação

Orientadora: Profa. Dra. Valéria Amorim Arantes 


\section{Brigitte Ursula Stach-Haertel}

A constituição de subjetividades legitimadoras das desigualdades de gênero: Um estudo a partir de referenciais da Psicologia e Educação.

Dissertação apresentada à Faculdade de Educação da Universidade de São Paulo como parte dos requisitos para a obtenção do título de Mestre em Psicologia e Educação.

Área de concentração: Psicologia e Educação

Orientadora: Profa. Dra. Valéria Amorim Arantes

Aprovada em:

\section{BANCA EXAMINADORA}

Prof. Dr.

Instituição: Assinatura:

Prof. Dr.

Instituição: Assinatura:

Prof. Dr.

Instituição: Assinatura: 


\section{RESUMO}

Este trabalho se insere na área da Psicologia Moral buscando investigar crenças e valores referentes à socialização de gênero, pautados nas representações de adolescentes, de camadas populares urbanas. Pesquisa realizada com pouco mais de duzentos jovens, entre onze e quinze anos de idade, de ambos os sexos, em uma unidade escolar da rede pública municipal na zona norte da cidade de São Paulo. Utilizou como ferramenta um questionário contendo dez afirmações incompletas que em sua primeira parte sugeriam associações aos papéis sociais, tanto em relação às feminilidades, quanto às masculinidades, complementados por conflitos de interesses, primeiramente entre pares do sexo oposto e posteriormente por parceiros de mesmo sexo. Aplicada a análise a partir dos referenciais dos modelos organizadores de pensamento às respostas dadas, foi possível identificar a idéia central a partir da qual se ancoraram as percepções dos jovens nas diferentes afirmativas. Os resultados obtidos demonstram que, ainda que meninas e meninos reconheçam, desde muito cedo, o mundo composto por seres sexuados, o fazem sem estabelecer juízo de valor. Entretanto, em certo estágio da puberdade, especialmente a partir dos treze anos, parcela das jovens e dos jovens, introduz variáveis que suspendem, de algum modo, a igualdade natural

entre os sexos estabelecendo hierarquias e subordinações que denunciam uma valoração, gradativa e díspar, dos papéis sociais relativos ao gênero.

Expressões chave: Psicologia Moral - Modelos Organizadores de Pensamento - Socialização de Gênero - Adolescentes das camadas populares urbanas. 


\begin{abstract}
This work falls in the area of Moral Phychology. We investigated beliefs and values that support teenager sex-role socialization, more specifically, social gender representations of young people from popular urban communities. Our research carried out with a little more than two hundred boys and girls, between eleven and fifteen years old, in a public municipal school, at the north zone of the city of São Paulo. We choose as research tool a questionnaire containing six incomplete statements that suggested associations to social roles, in relation to femininity or masculinity. It was supplemented by four different conflicts of interest, first among partners of the opposite sex and later on by the same-sex peers. Applied an analysis to the answers from the "Organizing Thought Models" references, it was possible to us to identify the central perception ideas in which, young people, anchored their representations for each one of the ten different statements. The results show that, although girls and boys recognize that the world is gendered at a very young age, they do not establish value judgments. However, from some stage during puberty, especially after thirteen years old, young women and young men introduce some variables that suspend, in some way, the natural equality between the sexes and established subordinations down hierarchies which complain the valuation, gradual and uneven, regarding to social gender roles.
\end{abstract}

Key words: Moral Psychology - Organizing Thought Models Gender Socialization - Teenagers of the urban popular classes. 
Há muitos a quem agradecer. Qualquer das formas, que eu aqui escolhesse, poderia trazer-me o risco de cometer alguns deslizes.

Em função disso, não ouso agradecer a todos aqueles que tenham feito por merecê-lo; seriam páginas e mais páginas tecendo comentários a respeito de cada um daqueles que contribuiu, a seu modo, para que eu pudesse, de fato, materializar esta etapa...

Os nomes a quem faço referência, de certa forma, representam, também, todos aqueles que sabem da sua importância para que chegássemos aonde chegamos. Decidi mencionar apenas seus representantes. Faço-o em ordem cronológica, apenas para definir alguma, porque nenhuma das formas que eu aqui adotasse seria isenta de possíveis lapsos.

Gratidão não se mede... Para o benefício que geraram a única medida cabível é observar os frutos que ajudaram a "adubar" com seu cuidado e atenção.

Primeiramente a Deus, pela benção da vida!

Ao Mestre, Jesus Cristo, cujos ensinamentos me fizeram acreditar que somos verdadeiramente seres de potencial infinito... "Vós sois luzes. Fazei brilhar a vossa luz!"

A Hans e Ruth, que me trouxeram à maravilhosa aventura chamada existência e, cujo exemplo de luta e determinação fizeram-me uma pessoa melhor.

A Dagmar, com quem aprendi a importância das nossas opções. Quantas travessuras! As conseqüências nos fizeram ver que, escolhas, têm necessariamente um preço...

Ao Walter, meu companheiro, parceiro e tantas vezes cúmplice. Sem o seu apoio, e por que não dizer, o seu arrimo, esta teria sido uma empreitada impossível. Obrigada pela compreensão das horas de convívio "roubadas". Agradeço pelos bilhetinhos espalhados pela casa com as suas mensagens de apoio. Compartilho apenas um deles: "Até que tentes, não saberás do que és capaz de realizar..."

À Karina, Daniela e Bianca que me inspiraram a desejar um mundo melhor para as futuras gerações. Dedico este trabalho especialmente a vocês, amadas filhas!

À Neusa - comadre querida - pelas palavras de incentivo. À Isabel - Bebel - por sua preciosa e estimulante "torcida". E especialmente à minha inseparável parceira Deílza, que cuidou de todos os detalhes para que eu pudesse concretizar mais este estágio.

À Susi e Carmem pelas substituições empreendidas em nossa jornada voluntária...

À Lúcia e Sônia pela tolerância e compreensão com minhas ausências, indisposições e atrasos no cumprimento de meus compromissos na Escola Estadual Ministro Salgado Filho. À Angélica e Rosana, da Diretoria de Ensino Sul 1, pela "sustentação" em momentos decisivos. 
Aos docentes da Faculdade de Educação da Universidade de São Paulo que em 2002 me acolheram na retomada estudantil.

Ao Prof. Dr. Romualdo Portela de Oliveira que me abriu as portas da pesquisa acadêmica junto ao CEPPPE/FE/USP.

Ao Prof. Dr. Vitor Henrique Paro cuja orientação ainda na graduação, durante projeto de Iniciação Científica, me guiou os primeiros passos pelas premissas do território investigativo.

À Profa. Dra. Marilia Pinto de Carvalho cuja contribuição inestimável, durante a qualificação, provocou a abordagem de novas perspectivas no aprofundamento de nossa análise. Ao Prof. Dr. Rogério Lerner, que na mesma oportunidade, por intermédio de seus questionamentos, me instigou a buscar no referencial teórico, tantas outras respostas, para muito além, daquelas anteriormente previstas.

Ao Prof. Dr. Ulisses Ferreira de Araújo pelas incontáveis e valiosas oportunidades oferecidas nas mais distintas frentes de trabalho, especialmente aquela que me permitiu a monitoria junto aos alunos da EACH - USP Leste - e, cujas observações de docente extraordinário, sempre pertinentes, me tornaram uma mestranda mais engajada.

À Profa. Dra. Valéria Amorim Arantes por ter depositado em mim a confiança que viabilizou cada pequena conquista deste longo trabalho; por sua competência acadêmica e seu entusiasmo contagiante com os quais orientou a minha trajetória na pós-graduação; por ter me instigado a buscar nas subjetividades, nuances para muito além das mais evidentes, o estímulo indispensável aos propósitos educativos. E especialmente por ter transformado a nossa relação orientadora/orientanda em algo absolutamente inesquecível... 
Não fomos preparados para compartilhar nem para resolver com agilidade e de forma não violenta os problemas que iam surgindo em nossas relações pessoais.

Não desenvolvemos a sensibilidade necessária para saber interpretar a linguagem de nossos sentimentos.

Nossa razão não foi exercitada na resolução de conflitos

e tampouco dispúnhamos de um repertório de atitudes e comportamentos práticos que nos permitissem sair dignamente de uma situação.

Em síntese, nossa formação nos tornou mais hábeis para lidar com o mundo fisico do que com o social; aprendemos mais coisas do mundo exterior que de nossa própria intimidade conhecemos mais os objetos que as pessoas de nosso convívio.

Sabemos, por ter experimentado os déficits de nossa própria formação, que é necessário mudar os processos de socialização das novas gerações...

Sabemos que a educação formal tem limites, que os(as) professores(as) não podem atenuar todos os déficits de um sistema social, que aumenta, lenta e progressivamente, a competitividade e a agressividade, inclusive no seio das instituições educacionais.

Apesar disso... Acreditamos que são [os(as) professores(as)] um dos estamentos sociais mais dispostos a prestar a sua generosa ajuda...

...às novas gerações. 
Se eu pudesse deixar algum presente a você, deixaria aceso o sentimento de amar a vida dos seres humanos. A consciência de aprender tudo o que foi ensinado pelo tempo afora. Lembraria os erros que foram cometidos para que não mais se repetissem. A capacidade de escolher novos rumos. Deixaria para você, se pudesse, o respeito àquilo que é indispensável: Além do pão, o trabalho. Além do trabalho, a ação.

E quando tudo mais faltasse, um segredo: o de buscar no interior de si mesmo a resposta e a força para encontrar a saída. 


\section{SUMÁRIO}

I. Introdução

13

\section{Fundamentação teórica}

II. 1 - Psicologia Moral

II. 1. A - Moral e ética

II. 1. B - Origem dos pressupostos teóricos da moralidade no Ocidente

II. 1. C - Psicologia e moral

a) Origens

b) Contribuições posteriores

II. 2 - Gênero

II. 2. A - Definições preliminares

II. 2. B - Contextualização histórica da temática de Gênero

II. 2. C - Evolução conceitual da temática de Gênero

II. 2. D - Concepções adotadas

52

II. 2. E - Socialização de gênero

II. 3 - Modelos organizadores de pensamento

II. 3. A - Origem das idéias de estruturas, esquemas e modelos

II. 3. B - A concepção dos modelos organizadores de pensamento

II. 3. C - Modelos organizadores do pensamento e psicologia moral

\section{Pesquisa de campo}

III. 1 - Definições preliminares

III. 1. A - Apresentação

III. 1. B - Definição da questão central de pesquisa

III. 1. C - Antecedentes

III. 1. D - Recorte adotado

III. 1. E - Pressupostos metodológicos

III. 2 - Resultados obtidos

III. 2. A - Descrição dos agrupamentos

III. 2. B - Descrição dos modelos da primeira fase

III. 2. C - Descrição complementar dos dados da primeira fase

III. 2. D - Descrição dos modelos da segunda fase 
IV. Análise dos dados

IV. 1 - Análise dos modelos da primeira fase 153

IV. 2 - Análise complementar da primeira fase

IV. 3 - Análise dos modelos da segunda fase

V. Considerações finais

162

VI. Referências bibliográficas

176 


\section{INTRODUÇÃO}

Formalmente, este é um trabalho que se insere no programa de pós-graduação oferecido pela Faculdade de Educação da Universidade de São Paulo; (espera-se) que deva atender às prerrogativas exigidas para a obtenção do título de Mestre em Educação.

Pessoalmente, vai ao encontro das inquietações que me acompanharam, desde que me entendo por gente, tentando compreender o que faz um ser humano se tornar mais humano.

Ou nas palavras de nosso querido mestre Paulo Freire, o que "faz gente se tornar mais gente?" O que as "encharca" da mais genuína especificidade humana?

Estas questões me trouxeram à Educação.

Durante anos peregrinei entre diferentes campos do saber. Não havia encontrado até então motivação suficiente para chegar ao final de um curso superior. Foram muitas as tentativas... E em número ainda maior, as desistências...

Simultaneamente, uma carreira bem sucedida pautada em muito empenho e dedicação pessoal me afastava ainda mais dos "bancos" escolares. Ironia! Foram anos dedicados ao "mercado financeiro".

Até que um incidente profissional me provasse o contrário, acreditava, sinceramente, que títulos pudessem garantir uma "boa formação"... Que recursos financeiros seriam necessariamente direcionados com o objetivo de construirmos um mundo melhor...

Achava eu que quanto mais estudo tivesse, mais ética tenderia uma pessoa a ser. Descobri, no entanto, que não há garantias de uma relação direta entre ambas...

De origem muito modesta sempre tivera a firme convicção de que, se "o trabalho dignifica o homem", o estudo certamente deveria “divinizá-lo".

Esta trajetória nasce, portanto de um "diálogo" - que estabeleci de mim para comigo mesma - entre o meu histórico e a academia.

Em 2002 me foi possível retomar os estudos.

Cheguei à Faculdade de Educação como "caloura" da Licenciatura Plena em Pedagogia decidida a "descobrir" o que poderia ter "dado errado" na formação daqueles que haviam demonstrado um efeito "colateral" tão indesejado dos processos institucionalizados da educação.

Foi um longo percurso!

Todas as nossas acaloradas discussões acadêmicas foram indispensáveis.

Diferentes perspectivas, opiniões a convergir com nossos ideais faziam-nos divergir em nossos posicionamentos pessoais. 
Simultaneamente foram surgindo outras oportunidades acadêmicas. Projetos de pesquisa dentro da academia iam permitindo um aprofundamento da reflexão a respeito das questões educativas, em suas múltiplas perspectivas.

A participação no projeto de pesquisa "Acompanhamento da trajetória escolar e profissional dos alunos da Universidade de São Paulo - Ingressantes de 1995 e 1998"1 em 2002, além de outro, intitulado "A administração escolar e a condição política da educação"2 no exercício 2003/2004, como parte de um programa de Iniciação Científica, financiado pelo $\mathrm{CNPq}$, abriram-me as possibilidades de conhecer outros tantos aspectos que perpassam a Educação.

Muitos foram os docentes inesquecíveis...

Citá-los seria redundância frente a uma carreira reconhecida e premiada.

Parecia que, enfim, estaria encontrando na Educação algumas pistas para as questões que sempre haviam me inquietado.

Foi, no entanto no segundo semestre de 2004 que teve início o percurso que me traz ao presente estágio.

Uma disciplina intitulada "Temas transversais da Educação" mediada pela Profa. Dra. Valéria Amorim Arantes abriu-me caminhos inimagináveis...

Quantas questões antes desconhecidas...

Quantas indagações lançadas...

As interrogações pareciam não ter respostas... Ou deveriam ser construídas?

Foi, inegavelmente, um "divisor de águas".

Uma parceria iniciada com o Trabalho de Conclusão de Curso - TCC - de título "Questões de gênero na resolução de conflitos interpessoais: um estudo com adolescentes" traz-me também ao programa de pós-graduação.

De minha parte um registro se faz indispensável...

"En-signare", deixar marcas.

A orientação sempre presente e assertiva, além de tantos outros ensinamentos no currículo institucionalizado, bem como naquele denominado "oculto", deixaram os seus próprios sinais transformando a "caloura" em mestranda; sonho que jamais ousara imaginar...

Descobri que a "boniteza" do ser humano não é condição previamente dada, nem tampouco garantida por esta ou aquela oportunidade que se venha a ter.

Mas, construída a partir de uma "prática reflexiva"...

Da coragem em recomeçar um pouco, a cada dia...

\footnotetext{
${ }^{1}$ Sob coordenação do Prof. Dr. Romualdo Luiz Portela de Oliveira (EDA/FE/USP)

${ }^{2}$ Sob coordenação do Prof. Dr. Vitor Henrique Paro (EDA/FE/USP)
} 
De olhar em todas as direções, buscando reconhecer a legitimidade em todas as manifestações da nossa mais genuína especificidade humana.

Este é, portanto, um trabalho fundamentado na quebra de paradigmas, especialmente os pessoais.

Quanto aos demais, lenta e gradativamente, têm se desvelado em estudos e pesquisas envolvendo o fenômeno educativo.

A hipótese que norteou a nossa investigação, inicialmente, foi a possibilidade de haverem mecanismos sociais que, de maneira subliminar, tenham a função de garantir a manutenção de desigualdades historicamente legitimadas e que possam, de algum modo, afetar a forma como as individualidades dão sentido à constituição de sua própria subjetividade.

Interessava-nos aprofundar as reflexões a respeito de possíveis crenças e valores, fortemente arraigadas a uma visão de mundo cosmopolita ocidental, que pudessem estar, de algum modo, sendo assumidas como referencial para as noções de pertencimento, especialmente entre os jovens. Se este fato viesse a se confirmar o fenômeno talvez estivesse implicando em uma série de adaptações e ajustamentos, em uma complexa teia de relações, que terminasse por naturalizar possíveis desigualdades, fator este que, no presente trabalho, se assentaria em questões de gênero.

A perspectiva androcêntrica que institui uma organização social bipolar, de extremos hierarquizados, estaria de fato presente, permitindo a desvalorização do elemento feminino? Uma vez identificada essa lógica patriarcal, seria possível que as próprias meninas estivessem assumindo, como legítima, uma visão de mundo subordinada aos interesses masculinos?

O resultado que apresentamos tem início com uma introdução na qual se pretende traçar, em linhas gerais, a origem e o encaminhamento dado às questões centrais que acabaram por gerar o presente trabalho.

O segundo capitulo apresenta uma discussão teórica que pretende fundamentar os eixos temáticos a partir dos quais entendemos que um direcionamento coerente com os nossos pressupostos iniciais poderia ser encaminhado. Percorrendo as prerrogativas da "Psicologia Moral" buscamos salientar alguns parâmetros centrais da origem deste campo de estudos e pesquisas apontando as suas principais conquistas e os desafios atuais. Um segundo aspecto abordado foram as questões de "Gênero" e as discussões às quais os(as) especialistas têm dedicado uma maior atenção, pautando seus esforços na identificação e denúncia de sua lógica e redes de influências. Apresentamos ainda, no mesmo capítulo, os fundamentos e preceitos de uma análise a partir dos "Modelos Organizadores de Pensamento", possibilidade 
esta, a partir da qual encaminhamos a nossa apreciação a respeito dos dados obtidos, durante a pesquisa de campo.

No terceiro capítulo dedicamo-nos a explorar o desenvolvimento da investigação, propriamente dita, e dos pressupostos a ela aplicados. Partimos das definições preliminares que nortearam os trabalhos apresentando o projeto que a inspirou, a unidade escolar na qual se realizou e o recorte adotado. Em item posterior detalhamos a metodologia utilizada, sua aplicabilidade aos fins a que nos propusemos e as principais implicações que destas derivaram, no decorrer do nosso trabalho, sustentando os resultados obtidos. Apresentamos os dados efetivamente encontrados, bem como gráficos e tabelas deles decorrentes de acordo com os critérios estabelecidos a partir da definição do objeto central da presente pesquisa.

O quarto capítulo, por sua vez, apresenta a análise e a discussão dos resultados efetivamente encontrados e tabulados, bem como as evidências que pudessem vir a sustentar os nossos comentários.

Couberam ao quinto capítulo as considerações finais cabíveis a partir do fenômeno investigado, de acordo com as premissas recomendadas a um trabalho acadêmico.

Acreditamos ter sido este um trabalho que se propôs a identificar uma das variáveis, entre milhares possíveis, que possa afetar a constituição das subjetividades, especialmente daquelas que se constroem em condições de vulnerabilidade social, geracional, afetiva ou ainda psíquica e que deva ser um compromisso coletivo refletir sobre a lógica social instituída, resgatando a nossa verdadeira "boniteza" no convívio pacifico e harmonioso entre semelhantes, que se reconhecem e se legitimam reciprocamente como tal, detentores das possibilidades de serem sujeitos da construção de um “outro mundo possível”... 


\section{FUNDAMENTAÇÃO TEÓRICA}

\section{1 - PSICOLOGIA MORAL}

\section{1. A - Moral e ética:}

Historicamente a espécie humana tem procurado pela felicidade.

Individual ou coletivamente, esta busca tem permeado as maiores e mais profundas reflexões. Na trajetória que os homens traçam visando alcançar esta conquista, muitos preceitos se fizeram presentes; na tentativa de estabelecer parâmetros mínimos que pudessem oferecer garantias para que se tornasse um patrimônio minimamente comum a todos os humanos, algumas questões se fizeram muito mais freqüentes.

Neste sentido é que moral e ética têm a sua importância destacada.

Para além de sua concepção, adotada como princípio ou teoria, tais termos têm estado presentes na discussão de muitos estudiosos.

Entre os pesquisadores do tema há claramente duas vertentes, uma que defende que moral e ética se equivalem e outra, que entende que ambas se complementam.

Entre aqueles que defendem não haver uma clara distinção, a argumentação fundamenta-se no fato de ser a ética uma tradução grega e a moral uma tradução latina de uma mesma idéia. Nesse sentido "ethos" do grego, e "morale" do latim significam algo relativo aos costumes, à conduta humana. Etimologicamente seriam, portanto, sinônimos.

Segundo o dicionário de Filosofia ${ }^{3}$, ética é a ciência que tem como objeto o estudo a respeito dos juízos de valor que distinguem o bem e o mal de forma praticamente atemporal. A moral é datada e suas normas e sanções mudam de acordo com cada sociedade, refletindo de alguma maneira a sua visão própria de mundo.

Um dos precursores da distinção entre os termos é Immanuel Kant, filósofo alemão, que influenciou profundamente os principais teóricos da abordagem com a qual se pretende fundamentar o presente trabalho, dentre eles Piaget.

Para Kant, a ética é algo universal, aplicável a todos independentemente do contexto sócio cultural no qual o indivíduo está inserido. Está associada à noção do "bem supremo”, da "felicidade". A moral por sua vez estaria vinculada aos costumes e valores dos grupos aos quais se pertence. É possível pensar, portanto que possa haver diferentes condutas consideradas morais de acordo com as tradições de cada povo, relacionadas àquilo que cada grupo associa com a possibilidade de alcançar a felicidade.

\footnotetext{
${ }^{3}$ In Rattner, 2004.
} 
A ética estaria associada aos ideais humanos.

A moral seria contextualizada e diria respeito a um sujeito histórico que baliza as suas ações em parâmetros de uma conduta considerada adequada, em benefício da maioria.

A ética está no campo do ideal de humanidade no qual se acredita e a moral na prática que impele à coerência com tal crença. De acordo com tal lógica, a moral é a conduta daquele que age de acordo com os seus princípios éticos.

Para Henrique Rattner, em artigo publicado na Revista Espaço Acadêmico, a ética

\begin{abstract}
...se refere a um devir, uma visão futura da humanidade que tem inspirado inúmeras gerações durante o processo histórico, cujos sujeitos 'desejantes' e ativos criariam comunidades de cidadãos ativos, fontes de liberdade que transformaram a História. Essa ética não é ficção ou sonho, mas uma visão do futuro construída por meio de um discurso em que se confrontam os valores por seus impactos reais e prováveis na existência humana. Ela surge como um amálgama e a recriação de aspirações e valores cultuados em todos os tempos, levando a uma síntese imaginária à luz das experiências políticas e práticas acumuladas.
\end{abstract}

RATTNER, 2004.

Ainda na corrente que distingue a moral da ética, De La Taille (2005b) propõe que a moral estaria situada no campo do dever e se proporia a responder à pergunta: “- como devo agir?", enquanto a ética estaria no âmbito daquilo que se busca alcançar como ideal e a resposta à qual se proporia responder seria: “- que vida quero levar?”.

Este mesmo autor afirma que ética é uma questão filosófica e moral uma questão prática.

Seja qual for a opção a ser feita, distinguir ou não moral de ética, fica claro que ao aplicar os seus pressupostos à Psicologia trata-se de investigar um sujeito posicionando-se frente a preceitos de conduta, sejam eles universais ou contextualizados. Desta maneira, Psicologia Moral é a área do conhecimento que se dedica ao estudo dos processos psicológicos, intelectuais ou afetivos, que sustentam os juízos e as ações morais.

\title{
II. 1. B - Origem dos pressupostos teóricos da moralidade no Ocidente:
}

A questão fundamental da moralidade, aqui assumida, está baseada na busca das ações humanas cujo efeito - ou conseqüências identificáveis - é desejável, não apenas no âmbito individual, mas especialmente no âmbito das relações que se estabelecem coletivamente.

Neste sentido é relevante lembrar que a moral sobre a qual refletimos não está de forma alguma associada àquilo que, no senso comum, acaba sendo confundido com moralismo. Moralismo é um entendimento restrito da questão dos deveres de um determinado sujeito, no contexto de uma coletividade que impõe normas e preceitos para uma conduta que seja considerada adequada. Essas recomendações de caráter, quase sempre, exclusivamente 
prescritivo, limitam a ação do sujeito, servindo especialmente para atribuir juízos de valor àqueles que ousem contrariá-las.

A moral no sentido adotado é antes que uma condição dada, um ideal a ser alcançado. Está profundamente enraizada no conceito piagetiano de autonomia, que vem a ser o resultado de um longo processo de construção de relações interpessoais que incentivam a busca da cooperação, fruto da reciprocidade e de acordos mútuos a serem continuamente construídos e reconstruídos.

A essência da moralidade adotada é a possibilidade de alcançar a condição de se colocar no lugar do outro, de perpassar o próprio julgamento dos fatos com o olhar daquele que também está envolvido em determinada circunstância - majoritariamente um conflito ainda que à custa dos próprios interesses.

A moral proposta dentro de tais preceitos só se constitui - se e somente se - o sujeito da ação está em condições de seguir a norma por uma opção livre e consciente de sua parte, alinhada com os princípios que ele mesmo adotou como norteadores de sua conduta, não apenas acatando-os, mas, acima de tudo, legitimando-os como adequados a seu projeto de mundo.

Alguns preceitos surgem em quase todas as teorias da moralidade. Uns estão explícitos como as questões do dever, do respeito e da justiça. Outros aparecem de uma forma implícita como a busca da "felicidade", do "bem comum" - ou "bem supremo" - e da "virtude". Permeiam suas proposições a investigação da natureza e das tendências humanas.

A discussão em torno da moralidade pode tomar diferentes direções, mas atribui, ainda que de forma subliminar, importância determinante aos fins a que atende e, principalmente, aos meios que emprega para justificar a ação humana.

Um dos pioneiros em tais questões é Aristóteles em sua obra "Ética a Nicômaco".

Em seu tratado preocupa-se com o "bem" humano e propõe uma ética normativa - e prescritiva - sugerindo que os "amantes da sabedoria" renunciem a seus próprios interesses e se distanciem o suficiente de tudo aquilo que de muito perto os afete, buscando salvaguardar a "verdade" e a isenção.

Em suas proposições entende que na busca da felicidade haveria certa hierarquia de fins, alguns fundamentais, outros menos relevantes. Os fins fundamentais de qualquer ação humana seriam indiscutivelmente superiores a qualquer outro propósito; estando os últimos necessariamente subordinados aos primeiros. Dentro de tal raciocínio defende a idéia de ser "absoluto e incondicional aquilo que é sempre desejável em si mesmo e nunca no interesse de outra coisa". (referência) 
$\mathrm{Na}$ visão aristótelica os fins de toda a ação humana deveriam conduzir ao bem coletivo, um "bem maior", instância acima dos interesses individuais e imediatos. O bem voltado ao coletivo é superior àquele que atende aos interesses de um indivíduo. $\mathrm{O}$ bem humano só o pode ser em sua relação de interdependência com os demais, sempre plural.

Entende que o "bem humano" é determinado por dois fatores, a natureza humana e as circunstâncias concretas - ou ocasiões - da vida. É no cruzamento desses dois fatores que a "boa vida" é alcançável. Quando seguidas as normas coerentes com a excelência humana, independentemente das circunstâncias concretas nas quais se encontra o indivíduo, as condições da "boa vida" são alcançáveis.

Para Aristóteles, as normas serviriam para harmonizar tendências opostas da natureza humana. Teriam um caráter de equilíbrio das próprias contradições, caminho único que permitiria alcançar a "felicidade".

O hábito de lidar com as contradições, submetendo a própria índole a regras e critérios cujo objetivo seja alcançar prioritariamente o bem comum, é o que Aristóteles chama de "virtude".

Há uma virtude que faz desejar viver conforme as leis, conforme a eqüidade, que torna os homens capazes de desejar e realizar atos pautados na imparcialidade. Essa virtude é a justiça.

A justiça, no pensamento aristotélico, é a mais importante das virtudes, virtude maior.

A questão da justiça torna-se tão relevante que estará presente, de algum modo, em todas as teorias posteriores a respeito da moralidade e seus pressupostos, dificilmente, serão superados, enquanto ideal norteador para a ação humana.

Outra influência indiscutível nos estudos da moralidade surge das idéias do filósofo Immanuel Kant.

Kant defende que alguns princípios universais seriam indispensáveis no sentido de instituir uma moralidade "apriorística", independente de circunstâncias ou interesses imediatos e/ou individuais.

Nesse sentido, a educação assumiria a função de permitir aos homens alcançar a liberdade e a felicidade, havendo um compromisso dos mais experientes em formar os mais jovens dentro das mesmas premissas. E pergunta-se: "Como poderíamos tornar os homens felizes, se não os tornamos morais e sábios?",

\footnotetext{
${ }^{4}$ KANT, 1999.
} 
Ainda que seja predominantemente reconhecida como referência, no que diz respeito à formulação de uma lei universal da moralidade e, portanto da noção dos imperativos categóricos, a posição de Kant atribuiu importância fundamental à natureza humana e à história particular de cada sujeito, como fatores constituintes de sua moral.

Para o filósofo alemão o homem é afetado por inúmeras inclinações que serão determinantes para a formação de seu caráter. O pensador afirma que as "inclinações naturais são um contrapeso à razão moral”.

Acredita que os homens são freqüentemente vencidos por inclinações menos desejáveis, sendo necessário fortalecer, pela educação, pelo exercício e pela vivência, as máximas de um comportamento "nobre".

Kant defende que a disciplina deveria ser imposta às crianças, atribuindo-lhe o sentido de "arrancar o homem de sua selvageria".

Há claramente a intenção de torná-lo cidadão por intermédio de preceitos morais buscando a formação para o convívio social. Afirma que o homem não é, por natureza, um ser moral.

Ainda que Kant entenda que a moral é um fenômeno cultural, no sentido de ser resultado de processos de desenvolvimento moral que ocorrem em uma coletividade, afirma categoricamente que a educação das leis da razão prática para alcançar o ânimo humano, enquanto índole, só pode ser feita individualmente. Forma-se primeiramente o caráter moral do indivíduo para melhorar, ou transformar, posteriormente a sociedade.

A ética estaria assim arraigada no uso da razão e o indivíduo seria estimulado a abstrair de suas próprias ações as regras a serem adotadas. Surge, portanto, uma ética mais reflexiva que prescritiva.

Essa condição é entendida como um atributo do desenvolvimento da inteligência. Aqui a virtude aparece como fortaleza moral decorrente da vontade; é a vontade, portanto, impondo-se à própria índole.

Kant profundamente influenciado pelas idéias de Rousseau ${ }^{5}$ afirma que crenças pessoais, não educadas pelo filtro de um princípio universal, são a origem das desigualdades.

Em seus tratados aparece a preocupação com a questão da autonomia, que tal como a justiça aristotélica, perpassará praticamente todas as teorias posteriores.

Pensar por si mesmo significa procurar em si próprio (isto é, na sua própria razão) a suprema pedra de toque da verdade... muitas vezes quem é excessivamente rico de conhecimentos é muito menos esclarecido no uso dos mesmos. Servir-se da própria razão, quer apenas dizer que, em tudo o que se deve aceitar, se faz a si mesmo esta

\footnotetext{
${ }^{5}$ Em "Como Gertrudes ensina a seus filhos" defende uma educação dos ideais humanos como forma de garantir a socialização dentro de preceitos "desejáveis".
} 
pergunta: será possível transformar em princípio universal do uso da razão aquele pelo qual se admite algo, ou também a regra que se segue do que se admite? Qualquer um pode realizar consigo mesmo semelhante exame e bem depressa verá, neste escrutínio, desaparecerem a superstição e o devaneio, mesmo se está muito longe de possuir os conhecimentos para a ambos refutar com razões objetivas.

KANT, 1995, p. 55.

Muitos aspectos do pensamento de Aristóteles e de Kant convergem, e alguns são especialmente relevantes por terem se transformado no eixo central de investigações posteriores das questões relacionadas à ética e/ou à moral.

Os dois atribuem à educação um papel fundamental na formação do caráter.

Tanto Aristóteles quanto Kant fazem suas reflexões pressupondo uma dualidade humana, na polaridade razão/emoção. Atribuem à razão, a força, o poder de controlar as emoções, o "ânimo". Enquanto Aristóteles defende o desenvolvimento da virtude para equilibrar tendências contraditórias, Kant defende que a moral seria fruto da ação da vontade, exercendo o seu controle sobre as demais tendências.

Vale apontar que tais pressupostos sobre a moralidade, como campo de embate entre razão e afetividade, ainda influenciam muitos autores contemporâneos.

Os precursores da discussão, ainda que defendam que a idéia da autonomia seja trazida para as questões morais como uma possibilidade de garantir às ações humanas uma ética universal, entendem que a disciplina é um atributo indispensável à educação, como desenvolvimento da noção do dever.

O “dever" será imposto, portanto, ao aprendiz como forma de disciplinar aquilo que motiva todas as suas ações.

Atribuem à questão dos fins, importância fundamental. Aparece fortemente a defesa de fins que sejam, por si mesmos, justificáveis, não devendo estar em hipótese alguma subordinados a qualquer outro tipo de interesse. Para Kant, o homem deve ser o fim em si mesmo e jamais o meio para alcançar determinados fins. Todos os fins devem, segundo o filósofo, convergir para um bem maior, a liberdade e a felicidade do homem.

Aristóteles e Kant acreditam que essa condição possa ser alcançada por intermédio da ação moral.

As concepções aristotélicas de moral, ainda hoje, estão profundamente arraigadas no pensamento ocidental.

A teoria kantiana, por sua vez, parece ter sido aquela que mais herdeiros deixou no campo do pensamento a respeito da Ética influenciando, inclusive, vários estudiosos da Psicologia Moral.

Influência, portanto, inegável... 


\title{
II. 1. C - Psicologia e moral:
}

\section{a) Origens:}

Como nas demais atividades humanas, toda e qualquer área do conhecimento será, irremediavelmente, influenciada por seus precursores.

Historicamente as raízes da Psicologia Moral remontam aos estudos e pesquisas feitos por Piaget com o público infantil. $\mathrm{O}$ autor buscava identificar a gênese do desenvolvimento cognitivo humano.

Para a Psicologia Moral é fundamental, então, tomar como ponto de partida os preceitos elaborados por Jean Piaget. Entender a moral, no sentido piagetiano do termo, implica buscar compreender a gênese da moralidade humana.

Para Piaget essa condição precisa ser desenvolvida, posto não serem inatas as disposições morais do indivíduo.

\begin{abstract}
O que é dado pela constituição psico-biológica do indivíduo como tal são as disposições, as tendências afetivas e ativas: a simpatia e o medo - componentes do "respeito" -, as raízes instintivas da sociabilidade, da subordinação, da imitação etc., e sobretudo certa capacidade indefinida de afeição, que permitirá a criança amar um ideal como amar a seus pais e tender ao bem como à sociedade de seus semelhantes. Mas, deixadas livres, essas forças puramente inatas permaneceriam anárquicas: fonte dos piores excessos como de todos os desenvolvimentos, a natureza psicológica do indivíduo como tal permanece neutra do ponto de vista moral.
\end{abstract}

PIAGET, 1996, p.9/10.

O teórico suíço concentrou suas pesquisas no estudo da constituição da moralidade, no universo infantil, evidenciando os primórdios do raciocínio moral.

Estruturou toda a sua teoria observando a atuação de crianças de diferentes faixas etárias em situações de jogos. Segundo de La Taille, "para Piaget, os jogos coletivos são paradigmáticos para a moralidade humana", 6

Os jogos são entendidos por Piaget como extremamente representativos, na gênese da moralidade humana, uma vez que o exercício de seguir as regras que regulam a atividade lúdica - e que deveriam, a princípio, ser seguidas por todos os seus participantes - desenvolve a habilidade do indivíduo em respeitar normas.

Ainda que tenham as suas normas estabelecidas sem a participação direta de nenhum de seus jogadores, os jogos infantis oferecem relativa flexibilidade a ponto de permitir alterálos desde que haja, para tanto, algum tipo de regulação. Importa que o desenvolvimento do respeito a essas regras sirva como parâmetro da conduta moral de um indivíduo, uma vez que envolve questões de justiça e de honestidade.

\footnotetext{
${ }^{6}$ De LA TAILLE, 2005a, p. 76.
} 
Piaget, na elaboração das bases de suas teorias sobre a moralidade, parece, de algum modo, dialogar com algumas das proposições feitas anteriormente por Durkheim e Bovet. (De La Taille, 2005a)

Os três autores convergem ao atribuir a moralidade ao resultado da conjunção de noções relacionadas ao dever e ao bem. Há, no entanto, distinções evidentes.

As restrições que Piaget faz aos demais autores citados estão centradas no fato de que, ainda que com matrizes diferentes, ambos estabelecem uma hierarquia subordinando o bem ao dever. Tanto para Durkheim quanto para Bovet, a obediência às regras, às leis, tornaria o sujeito moral enquanto Piaget defende que seja uma conseqüência do exercício da razão.

Em Durkheim, o dever tem caráter de obrigatoriedade e o bem, caráter de desejabilidade. $\mathrm{O}$ autor acredita que, tal como o sentido do sagrado, presente nas questões religiosas, a dualidade natural entre obrigatoriedade e desejabilidade, na conduta moral, é passível de ser regulada. O objeto que despertaria, simultaneamente, dever e desejo, e que regularia a moralidade humana seria a sociedade, instância infinitamente superior à realidade individual, dentro de sua concepção.

Nesse sentido a sociedade teria o caráter da autoridade, sendo identificada como coletivo superior, fonte única tanto para a noção do dever quanto para a noção do bem.

Enquanto Durkheim atribui à sociedade o papel da autoridade, capaz de fazer o ser humano agir moralmente, Bovet entende que essa autoridade é resultado de uma legitimação, fruto de interações significativas, nas relações interpessoais.

Bovet sugere que o respeito aos demais é condição prévia de toda lei moral.

Tentando esclarecer as condições indispensáveis à conquista da consciência de obrigação em um indivíduo, defende Bovet que seja possível querer agir de uma ou de outra forma em função de dois fatores. O primeiro é que seja dado aquilo que chama de comando de "consigne" - uma espécie de ordem ou proibição - e o segundo é que essa mesma “consigne" seja emitida por alguém que tenha prestígio ou autoridade aos olhos de quem irá acatá-la.

Para Bovet, o respeito seria fruto de uma relação muito especial, de natureza afetiva, onde amor e medo, em diferentes proporções, são seus constituintes.

Piaget defende que apenas o exercício da consciência torna o homem verdadeiramente moral.

Piaget diverge de Bovet e de Durkheim, pois estes últimos entendem a moralidade como decorrência, obrigatoriamente, de algum tipo de restrição, de desprazer, fruto de uma obrigação ou da renúncia a um desejo. 
Piaget, por sua vez, defende que a moralidade superior seja uma conquista que gere satisfação pelo fato de se agir no bem.

Em Durkheim a obediência é devida a um ser coletivo, superior - a sociedade - cujas premissas para uma conduta saudável devem ser seguidas pelo indivíduo. Em Bovet, a obediência é devida a um outro significativo, uma autoridade respeitada, seja por medo ou por amor.

Para Piaget ainda que a obrigação ou o dever sejam indispensáveis, não são condição suficiente para o desenvolvimento da moralidade. Em seu entender a moralidade não pode ser limitada a uma questão de interiorização de padrões impostos de fora para dentro. Seria preciso superar a condição de obediência, para alcançar o respeito.

$\mathrm{O}$ autor situa o respeito como fundamento das noções morais de um indivíduo. Esse sentimento, fundamental, para Piaget é o resultado das interações entre indivíduos, em uma relação interpessoal singular e suficientemente significativa.

Considera haver dois tipos distintos de respeito. Ao primeiro nomeia unilateral e ao segundo, mútuo ou recíproco. Ao respeito unilateral associa o conceito da coação, uma vez que há uma desigualdade natural, decorrente de uma forma de submissão, de uma criança frente a um adulto, de um ser menos experiente em relação a alguém mais experiente, resultante da primeira forma de interação social.

Bovet e Durkheim, em suas teorias, parecem não ter ultrapassado o primeiro estágio de desenvolvimento do respeito - unilateral ou de coação - como estruturante da moralidade.

Ao segundo tipo de respeito, Piaget associa o conceito da cooperação. Moralidade mais desenvolvida, uma vez que os indivíduos consideram-se pares, iguais em condições, para o exercício de seus direitos e para estabelecer acordos mútuos de reciprocidade.

$\mathrm{Na}$ teoria piagetiana o respeito unilateral geraria a noção do dever, uma moral "imposta", enquanto o respeito mútuo desenvolveria o sentimento do "bem", moral essa “mais desenvolvida" e desejada pelo próprio indivíduo.

A primeira está fundamentada na prática de determinações previamente estabelecidas e que, teoricamente, se é obrigado a cumprir, a segunda na consciência da função social das regulações.

Uma, é externamente orientada, regulada pelos outros; a outra é internamente centrada, e construída e regida pelo próprio indivíduo.

No primeiro estágio a regra é aceita como imutável, sagrada, acima do "bem" e do “mal”, portanto inquestionável, “exterior” ao indivíduo que a pratica. No segundo é possível 
construir as próprias regras - situação evidenciada pelos jogos infantis - em acordos que se estabelecem, entre iguais, havendo uma espécie de "contrato moral".

A cooperação em Piaget, exige segundo de La Taille, "que os sujeitos se descentrem para poder compreender o ponto de vista alheio. No que tange à moral, da cooperação derivam o respeito mútuo e a autonomia. Para Piaget, as relações entre crianças promovem a cooperação, justamente por se configurarem como relações a serem constituidas entre iguais.", 7

O sentimento da cooperação gera no indivíduo a tendência a observar as regras “justas” estabelecidas, seguindo-as voluntariamente.

Os dois tipos de respeito, unilateral e recíproco, têm efeitos bem distintos na constituição da personalidade, sendo apenas o último considerado estruturante para alcançar a condição desejável da autonomia ${ }^{8}$.

As concepções de Piaget a esse respeito parecem derivar de uma grande influência de Kant, para quem a moral seria conseqüência da necessidade humana de seguir regras. A natureza dessa obediência pode ser distinta, estando associada a "imperativos hipotéticos" ou “imperativos categóricos”.

Araújo (1996b) entende que a moral conquistada à custa de uma pressão externa, imposta, estaria sob a regência daquilo que Kant chamava de imperativos hipotéticos representando a necessidade prática de uma ação possível como meio de alcançar algo que se queira - e nos faça permanecer na condição da heteronomia.

A moral conquistada pela reelaboração interna das regulações sociais que pareçam justificáveis ou, dito de outra forma, pela capacidade que o homem adquire de escolher uma ação que esteja de acordo com o dever pelo exercício da própria vontade, ocorreria por intermédio dos imperativos categóricos - aqueles que nos representem uma ação como objetivamente necessária por si mesma, sem relação com qualquer outra finalidade - e nos levariam a atingir a autonomia.

De alguma forma, seria possível inferir que, na teoria de Piaget, a condição da ação, conforme prescrita pelo julgamento moral, conseqüência de um raciocínio moral relativamente independente, só se torna de fato possível a partir de um estágio em que o próprio indivíduo é capaz de discernir quanto às regras que sejam de fato consideradas "boas", havendo a necessidade de uma espécie de "validação".

\footnotetext{
${ }^{7}$ De LA TAILLE, 2005a, p. 83.

${ }^{8}$ Adotamos a autonomia aqui no sentido da consciência que o sujeito tem de que deva haver regras que regulem a convivência social e que sejam adotadas por vontade própria no intuito do bem comum.
} 
Um último ponto a ser lembrado é a questão da responsabilidade9. Também a responsabilidade na teoria piagetiana pode ser classificada em dois tipos. Uma objetiva e outra subjetiva sendo que o que as distingue é o fato de se considerar, ou não, a intenção intrínseca ao ato. A primeira atribui responsabilidade ao ato conforme sua gravidade aparente, evidente. A responsabilidade subjetiva, por sua vez, tenta identificar aspectos menos concretos, mais relacionados a uma possível intenção do indivíduo. Remete-se, ainda que implicitamente, à noção de justiça, pressuposto clássico em praticamente todas as teorias que se propuseram a discutir questões da moralidade.

Ainda quase que exclusivamente pautado no preceito da justiça, posteriormente, Lawrence Kohlberg lançou novas luzes à questão, defendendo que a moralidade humana passa por diferentes etapas, segundo ele, também, divididas em três níveis, cujo desdobramento, leva a seis estágios.

Ainda profundamente influenciado pelas teorias de Piaget, Kohlberg associa o desenvolvimento moral a estágios de desenvolvimento intelectual.

As afirmações de Kohlberg são resultado de pesquisas realizadas com crianças, adolescentes e adultos entre as décadas de 60 e 80 do século XX, em que pretendia identificar o raciocínio que sustenta o julgamento de um indivíduo diante de um dilema moral.

De um estágio primitivo em que "bom" é aquilo que se quer - ou se deseja - ao mais elevado, regido por princípios éticos universais, o indivíduo iria alcançando nova condição moral, em decorrência de seus avanços intelectuais.

Para Kohlberg a moralidade humana seria constituída pela passagem por três níveis. Cada um desses níveis teria por sua vez dois estágios.

Ao primeiro nível denominou pré-convencional. Nessa etapa o indivíduo não é regulado pelas convenções sociais. Age de acordo com seus próprios interesses, fazendo somente o que tem vontade ${ }^{10}$.

O nível pré-convencional está subdividido em dois estágios. O primeiro estágio é aquele em que apenas os interesses pessoais são levados em consideração. O segundo estágio apresenta os interesses pessoais, eventualmente, regulados por um medo pela punição.

O segundo nível é considerado convencional. Nessa etapa o indivíduo passa a dar grande importância às convenções sociais e às aparências. O princípio de regulação moral é a

\footnotetext{
${ }^{9}$ As concepções de respeito e responsabilidade aqui apresentadas estarão bastante presentes na análise dos dados obtidos em nossa pesquisa de campo.

${ }^{10} \mathrm{O}$ termo não está aqui empregado no sentido que lhe atribui Kant como força capaz de dominar os nossos instintos. Representa impetuosidadde, vontade totalmente indomada.
} 
"obediência cega" ao que está determinado, sendo extremamente significativo o desempenho "correto" de um papel social.

O nível convencional também está subdividido em dois estágios. O terceiro estágio, dentro da seqüência, é aquele em que as ações são reguladas pelas aparências. É o estágio em que se age fazendo aquilo que os outros esperam que seja feito; a prioridade é atender às expectativas alheias. No entanto não há, ainda, nenhuma garantia de que na ausência de um outro regulador a ação seja moral. O quarto estágio é o de obediência incondicional às leis, às regras e às convenções. As normas são tomadas como sagradas, imutáveis, inquestionáveis.

O terceiro nível de julgamento moral, dentro da mesma concepção, é o chamado nível pós-convencional. É a etapa em que a ação é regulada não por imposições externas, mas por princípios morais universais. Só tem valor moral aquilo que possa vir a ser aplicado a todos indistintamente, independentemente de interesses pessoais ou convenções sociais.

O terceiro nível, tal como os anteriores, tem duas subdivisões: o quinto e o sexto estágios. O quinto estágio representa a condição em que o indivíduo considera norteador de sua conduta moral o contrato social. Moral é aquilo que é fruto de acordos que seguem princípios de um código comum estabelecidos coletivamente. O sexto e último estágio seria a condição da moralidade mais elevada. Representada pela condição do indivíduo que considera as suas ações tomando como referência princípios éticos universais - os imperativos categóricos de Kant - orientados pela própria consciência.

Sua teoria baseia-se na perspectiva de haver um caráter universal para o desenvolvimento do juízo moral humano, também baseado no princípio da justiça.

Tanto a teoria de Piaget quanto a de Kohlberg, a respeito da moralidade, parecem ainda continuar muito influenciadas pelos preceitos aristotélicos da hierarquia dos fins, nas ações humanas.

Tanto a orientação da justiça para a moral e a ética, quanto a questão da subordinação de alguns preceitos a outros, parecem continuar norteadoras das propostas mais defendidas pelos teóricos da Psicologia Moral até a atualidade.

\section{b) Contribuições posteriores:}

Avançando na questão da gênese da moralidade humana, outras contribuições mais recentes se fizeram relevantes.

Uma das mais discutidas vem de Carol Gilligan, cujas pesquisas demonstraram que, para além do eixo da justiça no raciocínio moral dos indivíduos, parece haver outros atributos 
que podem intervir na análise da conjuntura de uma situação que o indivíduo considera para elaborar os seus juízos morais.

Suas primeiras hipóteses levantaram questionamentos em relação às afirmações de Kohlberg quanto ao juízo moral, centrado apenas na justiça, especialmente em função do fato de que haveria uma constatação subseqüente no sentido de que apenas os homens alcançariam o estágio superior de entendimento da justiça e, consequentemente, o estágio mais elaborado de desenvolvimento da moralidade.

A justiça conforme adotada por estas teorias estaria predominantemente pautada em concepções derivadas do convívio no espaço público, instância esta historicamente freqüentada de forma predominante pelos indivíduos do sexo masculino.

Seria possível inferir que o amadurecimento moral dentro dos pressupostos da teoria de Kohlberg estaria atrelado a uma espécie de desenvolvimento da capacidade de analisar os fatos dentro dos princípios de justiça, enquanto sistema de direitos e deveres, que regulam a convivência social.

Para além do caráter dos direitos e deveres estabelecidos por contratos sociais pautados nos princípios da justiça há, segundo Gilligan, uma instância menos abrangente e que poderia estar centrada em características singulares de uma dada situação, peculiar aos envolvidos, introduzindo uma análise mais voltada ao "cuidado" com questões específicas.

A autora acredita haverem dois eixos que norteiam a moralidade humana; acrescenta ao princípio da justiça, o cuidado, ou "care”. Nesse sentido, defende que o eixo da justiça seria priorizado nos juízos morais dos homens e o cuidado, ou responsabilidade, nos juízos morais de mulheres, em função de suas experiências bastante específicas de socialização.

\footnotetext{
Apesar de a autora não ter elaborado uma teoria do desenvolvimento moral, foi ela quem introduziu de forma mais sistemática uma discussão das diferenças de gênero no campo da psicologia moral.
}

MONTENEGRO, 2003.

Gilligan propõe como especificidade feminina uma identidade baseada em conexões e relacionamentos. A seu ver essa especificidade, confundida com atrofia do desenvolvimento moral por alguns autores, seria na verdade um caráter mais relacional, confundido com parcial, do juízo moral.

Ao desenvolver seu conceito de ética do cuidado, Gilligan elabora uma nova concepção de ética e efetua uma crítica de aspectos das teorias de autores consagrados no campo do desenvolvimento moral e da psicologia cognitiva, como Jean Piaget e Lawrence Kohlberg, assim como Freud. Esses autores, de diferentes maneiras, compartilham a idéia de que as mulheres apresentam uma parada ou atrofia no desenvolvimento moral. Segundo Gilligan, incorre-se nesse tipo de 
interpretação do desenvolvimento moral das mulheres quando se assume implicitamente a experiência dos homens como regra, utilizando-a como lente na observação do comportamento feminino.

MONTENEGRO, 2003.

Ao atentar para a evidente distorção de que as mulheres, de forma generalizada, não teriam condições de alcançar o patamar mais elevado da moralidade, Gilligan observou que o sujeito, ainda que impregnado pela influência daquilo que o constitui socialmente, pode recorrer a mecanismos particulares de julgamento constituídos a partir de uma experiência individual, carregada de sentimentos e emoções próprios à singularidade de cada indivíduo, tão legítimos quanto a "justiça" dos direitos e deveres.

Los trabajos de Gilligan ponen en evidencia el carácter reduccionista del modelo
androcéntrico de Kohlberg, ya que para él no existia más modelo que el de la
justicia, producto de tener en cuenta únicamente la mitad de la población y de
considerar como anomalía el no adecuarse a este único modelo lineal. Pero aun hay
más. Esta forma de actuar no sólo excluye el pensamiento de la mitad de la
población humana, pretendiéndose universal, sino que además solo considera un
ámbito social, el de lo público, ignorando el de lo privado en el cual tienen lugar
la mayor parte de las interacciones afectivas entre los individuos humanos. (grifos nossos) SASTRE \& MORENO, 2000, p. 128.

Ainda que Gilligan tenha tido como objetivo alertar para o fato de que a moralidade demanda de outros princípios para além da justiça, ao concentrar os seus esforços em evidenciar uma possível distinção entre os preceitos éticos, predominantemente adotados por mulheres e aqueles preferencialmente adotados por homens, parece ter fomentado a defesa de uma "natureza tipicamente feminina".

Ao pretender ampliar a compreensão do desenvolvimento ético humano contribuiu para interpretações parciais, dessa vez sob uma ótica essencialmente feminina.

No entanto, a mesma autora alerta para o fato de que a "ética do cuidado", forma como têm sido nomeados ao longo dos anos os seus estudos e investigações, é uma maneira simplista de abordar uma denúncia frente às diferentes condições e circunstâncias em que se constituem as singularidades, em um cenário marcadamente patriarcal.

Neste sentido, durante suas pesquisas, atentou para a questão de ocorrerem certas "rupturas psíquicas" durante a socialização de meninos e de meninas, em momentos e estágios distintos, cujas conseqüências também se manifestam diferentemente.

Para a autora a crise de Édipo dos estudos freudianos, uma dissociação psíquica que ocorreria na infância masculina, teria seu "equivalente feminino" durante a adolescência.

In studies of girl's psychological development, my colleagues and I have witnessed the onset of dissociative processes at adolescence (Brown and Gilligan, 1992; Gilligan, Brown, and Rogers, 1990; Rogers, 1993). Girls at this time face a relational crisis or developmental impasse which has its parallel in the relational crisis of boys early childhood. Freud called this crisis the Oedipus complex and theorized it as a turning point in psychological development, making a definitive 
intersection between psychological development and the requisites of civilization. The resolution of the Oedipus Complex structures the connection between inner and outer worlds.

I have come to theorize a similar crisis in girl's lives at adolescence as a crisis of voice and relationship, also making a definitive joining between psychological development and civilization. This is the time when girls are pressed from within and without to take on the interpretative framework of patriarchy and to regulate their sexuality, their relationships, their desires and their judgments in its terms. As for boys in early childhood this internalization of a patriarchal voice leads to a loss of relationship or a compromise between voice and relationships, leaving a psychological wound or scar. The asymmetry I have posited between boy's and girl's development finds confirmation in the considerable evidence showing that boys are more psychologically at risk than girls throughout the childhood years and that girl's psychological strengths and resilience are suddenly at risk at adolescence (see Gilligan n.d.a.; Debold, 1994)

GILLIGAN, 2003, p. 158.

No caso feminino esta dissociação psíquica que, conforme a autora, ocorreria durante a puberdade acarreta para as meninas, em uma negação das próprias conquistas, causando a impressão de que elas "não soubessem o que sabem, não pensassem o que pensam, não sentissem o que sentem" afetando a sua auto-estima e a maneira de se posicionar no mundo, em uma dissociação que exclui parte da sua história e da sua memória da lógica social.

O fenômeno para o qual nos alerta Gilligan parece ter sido amplamente reconhecido por várias estudiosas feministas, especialmente entre as historiadoras.

A título de ilustração remetemo-nos a uma entrevista concedida por Michelle Perrot ${ }^{11}$, ao $\mathrm{OESP}^{12}$, que de maneira informal dialoga com esta temática abordando a "invisibilidade" feminina na história da humanidade.

$\mathrm{Na}$ oportunidade a entrevistada reafirmava que, tradicionalmente, as mulheres tiveram a sua atuação quase que exclusivamente limitada ao espaço privado, reservado "às senhoras do lar", o que, segundo ela, teria contribuído de maneira relevante para o desaparecimento da história das mulheres "sem deixar vestígios" e acrescenta:

... Fora isso, a História com "h" maiúsculo preferiu registrar a passagem pelo mundo de mulheres notáveis ou excepcionais. Como Catarina de Médici (1519-1589), a soberana sempre lembrada para exemplificar os inconvenientes das mulheres no poder.

PERROT, 2007, p. J4.

Em seu raciocínio apontou outros fatores extremamente significativos presentes na raiz das dificuldades de reverter o quadro de discriminação, quase sempre velada, em relação às mulheres.

Posso afirmar o seguinte: a construção da história das mulheres depende delas próprias, mesmo que não estejam diretamente vinculadas a isso. $\mathrm{O}$ ponto de partida dessa construção pressupõe uma certa autonomia e acesso à cultura. No fundo, as

\footnotetext{
11 Michelle Perrot, historiadora feminista francesa autora do livro Minha história das Mulheres (Contexto:2007)

${ }^{12}$ Caçadora de memórias femininas. São Paulo: O Estado de São Paulo. Caderno Aliás, 04/07/2008, p. J4/J5.
} 
mulheres tomam sua história nas mãos da mesma maneira como tomam seu destino nas mãos. Daí o avanço das ocidentais. Mais emancipadas, elas puderam recuperar uma trajetória. Isso significa que estamos 'nem aí' para as mulheres de outras partes do mundo? Desprezamos o que não seja nosso? Não é isso, porém, honestamente, não poderemos substituir as mulheres africanas na construção de sua história. Seria como colonizá-las de novo.

PERROT, 2007, p. J4.

Para esta autora um dos maiores desafios a serem superados para a conquista da eqüidade entre os gêneros é uma tendência a privilegiar uma história predominantemente pública, referendada em conquistas e feitos masculinos, sem atentar para a contrapartida feminina.

Ao que tudo indica "romper o silêncio", expressão recorrente na obra da precursora Gilligan, parece ser um dos passos indispensável para avançar em questões atávicas, especialmente, se aplicadas à relevância que toma a autonomia na conquista de um patamar mínimo de igualdade e equidade de direitos e oportunidades.

Apesar da grande contribuição trazida à discussão teórica da moralidade, para muitos, ao que tudo indica, Gilligan não conseguiu, ainda, superar a tradicional dicotomia entre razão e emoção. Traduziu tal dicotomia para uma oposição entre justiça e cuidado ou, dito de outra forma, entre universal e pessoal, entre público e privado.

De La Taille defende que a maior contribuição de Gilligan teria sido acrescentar aos estudos e pesquisas do objeto moral das investigações psicológicas uma nova variável, que desta feita considerou pertinente o fator gênero, atribuindo-lhe peso equivalente e trazendo-o à discussão.

No entanto, o fato de se considerar tais questões não garante que uma efetiva transformação se concretize de fato e de direito.

$\mathrm{Na}$ esteira de tais discussões, outras estudiosas, no Brasil, debruçaram-se sobre questões pertinentes à autonomia moral da mulher.

Silva (1995) abordou o tema a partir de costumes e tradições de significação profunda:

Quem não tem poder de decisão sobre o seu destino não é livre, logo é um ser sem autonomia, deslocado do tempo da história, apenas uma imagem captada pelo espelho retrovisor...

As mulheres, pelo próprio condicionamento cultural, são conduzidas a uma concepção de si mesmas em autodepreciação, em que avulta a busca de identidade. Até bem pouco tempo, ao casar, a mulher perdia um ou até dois sobrenomes oriundos de sua família, o que nos lembra o escritor Alex Hailey, em seu romance Raízes, no qual o principal personagem Kunta-Kentee, ao chegar na América, cativo, perde seu sobrenome e recebe um outro, atribuído por seu dono, e percebe, com esse fato, que é uma forma de destruição de sua identidade.

SILVA, 1995, p. 112. 
Saffioti (2002), outra estudiosa da questão, afirmou que a própria concepção da autonomia, fundamental para o desenvolvimento moral, no caso da mulher, é distinta em seu entendimento quando vinculada ao papel masculino.

Segundo a pensadora feminista, a autonomia, quando legítima, é fruto de uma cessão de direitos entre pares de representatividade equivalente, em que ambos têm paridade para estabelecer "as regras do jogo" ". No entanto, a posição relativa da mulher teria sido e continuaria sendo, até os dias atuais, de uma autonomia apenas consentida. Dentro desta lógica, o elemento masculino, estaria "cedendo" parte de seu espaço de participação nos espaços públicos, sem que fosse efetivamente legitimada uma igualdade concreta de direitos e conquistas tanto sociais quanto políticas, fenômeno este que, portanto não garantiria a conquista da equidade nos espaços privados.

Afirma que esta concepção de autonomia "consentida" é relativa e afeta significativamente o "empoderamento" das mulheres que demandariam de um instrumental de emancipação e de libertação mais centrado na elevação de sua auto-estima.

É inegável que muito daquilo que ainda se vê no cotidiano de milhares de meninas e de mulheres, especialmente nas camadas menos favorecidas da população, está profundamente arraigado em modelos hegemônicos ${ }^{14}$ de valorização do elemento masculino.

$\mathrm{O}$ aprofundamento gradativo de estudos com o olhar voltado unicamente às variáveis mais defendidas pelas feministas, no entanto, mais uma vez, demonstrou que há uma tendência ocidental de posicionamentos extremados, ora em um pólo, ora em outro.

Em oposição à "moldura" androcêntrica da ciência, estabeleceu-se um olhar excessivamente centrado apenas nas experiências das mulheres sem relativizar que as experiências das masculinidades e das feminilidades estão em constante interação; tensões e conflitos são próprios deste território.

Seja como for, de uma base pautada unicamente na justiça e atribuída como habilidade exclusiva da conduta moral masculina, Gilligan ainda que não tenha superado a dualidade tão profundamente arraigada no pensamento ocidental -, instituiu-a, derrubando o império da unicidade do juízo moral humano a partir de uma perspectiva exclusivamente androcêntrica.

\section{c) Tendências atuais:}

As contribuições são inúmeras e não constituíram o objeto central de estudo do presente trabalho que buscou fundamentar o quadro teórico nos clássicos da área entendidos como basilares para as nossas etapas futuras.

\footnotetext{
${ }^{13}$ Remetemo-nos aqui à concepção de "respeito mútuo" de Piaget que pressupõe a cooperação e a reciprocidade entre "pares" de poder equivalente conforme vimos anteriormente.

${ }^{14}$ Assumimos modelos hegemônicos como padrões e parâmetros adotados cuja primazia inibe a sua contestação.
} 
Ampliando as concepções no campo da moralidade, especialmente quanto à crítica referente à dualidade das questões morais propostas por seus precursores, Benhabib (1992) propõe que a verdadeira constituição moral é construída a partir da introdução de um novo fator, a possibilidade de reconhecimento da legitimidade da existência de um outro sujeito, tão real e material quanto aquele que tem sido o objeto central de todas as teorias da moralidade.

Introduz a noção do "outro generalizado" e do "outro concreto". O "outro generalizado" estaria fundamentado em princípios de igualdade formal - meramente jurídica - enquanto o "outro concreto" estaria baseado em critérios menos genéricos e abstratos, tendo uma história própria, reconhecida e legitimada, caracterizando-o como sujeito de desejos e vontades, ou nas palavras de Lévinas ${ }^{15}$ um outro "assumindo um rosto”.

Ao adotar a perspectiva de um "outro concreto" seria possível considerar diferentes pontos de vista para analisar as variáveis que compõem um dilema moral. Para muito além da justiça, e até mesmo de um possível "cuidado" com o interesse alheio, seria alcançar a condição de considerar aspectos não evidentes - pautados nas aparências - na análise de uma determinada situação.

Posição semelhante adotam Campbell e Christopher para quem este campo de estudos apenas conseguiu alcançar os patamares iniciais das discussões sobre a complexidade do raciocínio moral humano.

\begin{abstract}
A principal premissa de Campbell e Christopher ${ }^{16}$ é a de que os estudos sobre desenvolvimento moral em psicologia não conseguiram desvencilhar-se da herança dualista kantiana, que traduziu a oposição razão-emoção na oposição universalpessoal. Nessa oposição, o universal tem prevalecido, propiciando uma dominância de pesquisas voltadas para o estudo da moral como justiça. Essa oposição significa, pois, não só uma cisão no ser humano, mas, no plano metodológico, a exclusão de certas questões do campo dos estudos da moral, especialmente aquelas referentes à individualidade. Nesse contexto, um dos méritos reconhecidos dos trabalhos de Gilligan foi o de ampliar o campo de estudo da moral, introduzindo a concepção de moral como cuidado - embora retomando a díade razão-emoção, universal-pessoal.

Para Campbell e Christopher, o que tem caracterizado o pensamento moral é a rígida separação entre o que é considerado moralidade e o que é considerado busca de objetivos particularistas. Quanto mais o comportamento moral se aproxima de um objetivo pessoal, mais ele se descaracteriza. Essa separação entre moralidade e interesse particular, que constitui um dos princípios da filosofia kantiana, limita a concepção de moralidade. Tal limitação se expressa na restrição do número de problemas morais estudados e na incapacidade de explicar como outras formas de conduta moral podem se desenvolver.
\end{abstract}

MONTENEGRO, 2003.

Ainda que partindo de diferentes pressupostos, cada um desses pensadores a seu modo - historicamente situado e limitado a seu próprio contexto - pretendeu encontrar meios de

LÉVINAS, 2005.

16 CAMPBELL \& CHRISTOPHER (1996). 
compreender como se forma, como se educa, como se incentiva uma personalidade, singular, moral e ética, viabilizando a prática e o usufruto da mais genuína especificidade humana.

Ultrapassando a condição de ideais humanos utópicos, acreditaram poder encontrar a gênese de um "bem supremo", alcançável por juízos e ações morais pautados na justiça, no cuidado, na responsabilidade e outros atributos "virtuosos" como forma de garantir " a tal felicidade" não apenas para si mesmos, mas acima de tudo para todos os "outros" significativos e "concretos", entendidos e tratados como semelhantes.

A complexidade humana permite aventar a necessidade de, continuamente, aparecerem novas questões, com a inserção de variáveis que admitam a ampliação dos horizontes de análise introduzindo, ainda, outras questões.

Interessa-nos aqui, particularmente, a possibilidade de imputar à questão do respeito importância suficiente para tomá-lo como um dos possíveis pressupostos da moralidade, especialmente se retomarmos uma das premissas da teoria piagetiana que defendia o respeito como estruturante para a autonomia moral.

Considerando ter sido o respeito um dado especialmente relevante em nossa pesquisa de campo, associado tanto a mulheres quanto a homens, ainda que com significados razoavelmente distintos, entendemos ter encontrado uma possibilidade de investigação da moralidade, para além dos atributos mais clássicos e polarizados na oposição razão-emoção, universal-pessoal, abstrato-concreto, entre tantos que possam permitir outras indagações e questionamentos, abrindo novos espaços para a nossa investigação e pesquisa.

\section{2 - GÊNERO:}

A adoção do conceito de gênero, historicamente construído, é um passo importante para sairmos das explicações das desigualdades a partir de fundamentações que se baseiam nas diferenças físicas, biológicas. As relações entre os sexos são construídas socialmente e, portanto, podem ser mudadas, assim como a hierarquia entre homens e mulheres.

VIANNA, 2003, p.47.

Entre as inúmeras possibilidades de fazermos um recorte para a realização de uma investigação acadêmica, pautada em preceitos que possam fomentar uma lógica da desigualdade, algumas têm se mostrado particularmente frutíferas, para a análise de um fenômeno cultural que acaba por influenciar profundamente as subjetividades em construção.

Crenças e valores amplamente arraigados em práticas do cotidiano parecem contribuir, significativamente, para a extensão e continuidade de algo hegemonicamente legitimado na coletividade, em relações que se estabelecem particularmente, entre os indivíduos, e que acabam, muitas das vezes, por naturalizar diferenças como forma de banalizar a desigualdade. 


\section{2. A - Definições preliminares:}

O único modelo cultural capaz de oferecer nova vida a um Ocidente agora disseminado sobre grande parte do globo é aquele que opõe à polarização de um tipo de modernização, hoje em declínio, o movimento inverso, o da recomposição e da recombinação dos elementos que haviam sido separados para que um dominasse o outro. Modelo que propõe também a idéia de que o novo é criado e administrado por aquelas que haviam sido a principal figura da dependência e que agora tentam superar a oposição homens/mulheres em vez de substituir a dominação masculina pela dominação feminina.

TOURAINE, 2006, p.214.

Ainda que as observações da epígrafe possam merecer inúmeras críticas pela forma simplista com que abordam o "modelo" cultural do Ocidente é preciso considerar que há uma lógica inerente à forma com que apreendemos o mundo em que vivemos.

Como seres sociais que somos, modelamos nossa subjetividade em um contexto de possibilidades construídas pela trajetória daqueles que conosco compartilham a experiência de humanos.

Esse percurso, individual e simultaneamente coletivo, gerador de um movimento singular, semelhante ao pêndulo que oscila (entre as extremidades), permeia a constituição da subjetividade de cada um.

Não nos constituímos psiquicamente de representações ou percepções descontextualizadas. Traduzimos as nossas impressões por intermédio de um repertório construído coletivamente.

Pertencemos a grupos que, historicamente, construíram suas maneiras de definir e delimitar o mundo, influenciando sobremaneira os nossos próprios princípios. Todas as nossas concepções fundamentam-se, de algum modo, de maneira mais ou menos explícita, em construções histórico-sociais que permeiam nossa visão de mundo.

As sociedades complexas contemporâneas tecem as possibilidades a partir das quais um sujeito se constitui em múltiplas facetas, influenciando sobremaneira a rede de significações que o envolvem e das quais participa, irremediavelmente, de forma, mais ou menos, consciente, reproduzindo ou rompendo com os "modelos" que estão postos.

São formas de hierarquização do pensamento ocidental e que vigoram há séculos, mas esgotam-se hoje diante da urgência de repensar a lógica que nos trouxe aos impasses atuais, de desordem e desequilíbrio de todos os matizes.

As mudanças que temos demandado para a implantação de uma coletividade mais justa, mais democrática e igualitária, intentando viabilizar a convivência pacífica e digna entre semelhantes, passam pela identificação e denúncia de possíveis variáveis que possam estar contribuindo para a manutenção de privilégios historicamente construídos. 
É incontestável que as variáveis, classe e raça, têm justificado arbitrariedades de toda ordem, em instâncias as mais diversas, especialmente quando atentamos para os aspectos mais evidentes da vida pública.

É inegável, também, que por intermédio de ações afirmativas e legislações específicas, muito se tem avançado nesta direção.

E que há muito, ainda, a se fazer...

No entanto, foi, nas relações de gênero que buscamos identificar os aspectos mais significativos daquilo que aqui identificamos como variáveis relevantes para certa continuidade em um "modelo" cultural de desigualdade.

Permeadas das sutilezas próprias do que se constitui na esfera do privado, muitas das vezes reforçadas por mecanismos inconscientes, algumas destas variáveis parecem se estender e influenciar outras dimensões das relações de poder inerentes às questões de gênero.

Neste sentido, é importante a contribuição de Crawford \& Chaffin (1997), que didaticamente abordam as questões de gênero como uma construção daquilo que seria "fazer o gênero" enquanto processo contínuo, indeterminado e inacabado, que se constituiria basicamente de três níveis.

Tais níveis são entendidos como distintos apenas no escopo de estudos que se proponham aos planos mais específicos de investigação que estão, no entanto, intimamente associados quando da dinâmica de suas influências no cotidiano das individualidades.

Um primeiro trata das questões socioculturais e, portanto, abarcaria aquilo que é próprio do coletivo mais amplo, como hábitos, costumes e práticas de cada sociedade, em um determinado tempo histórico.

Um segundo estágio seria aquele que os autores chamam de estágio interativo, próprio dos intercâmbios que se fazem entre os sujeitos, no qual se enquadram as relações que estabelecemos, uns para com os outros, nas mais distintas instituições às quais nos associamos por escolhas ou inserções, mais ou menos, voluntárias.

O último, e especialmente relevante, para a análise à qual nos propusemos, seria um nível mais individual, mais específico à forma como cada subjetividade percebe e dá sentido à construção de seu papel de gênero, sempre singular, "traduzindo" as demais instâncias em crenças, valores e condutas individuais.

Para o fim de explorarmos mais atentamente o último nível proposto por Crawford \& Chaffin recorremos à contribuição de Oliver y Valls (2004) que, buscando fazer um recorte mais específico em mecanismos de atração e escolhas do próprio indivíduo, muitas das quais 
não conscientes, propuseram uma análise mais profunda das diferentes significações e representações que a questão assume, individualmente, a partir de quatro níveis.

O primeiro intitulado "microsistema" seria um "sistema" de práticas e condutas associadas à família. A família, por intermédio de comportamentos instituídos, estabelecidos no núcleo familiar como sendo desejáveis, contribuiria para transformar tais práticas em crenças e valores que tenderiam a ser mantidos.

Um segundo, denominado "mesosistema" diz respeito aos contextos, ou instituições, nos quais cada um de nós está inserido, onde buscaríamos referenciais para as nossas ações. Os grupos tenderiam a definir certos padrões de conduta, decisivos para as noções de pertencimento, especialmente relevante no caso dos adolescentes.

$O$ "exosistema", correspondente às influências das estruturas sociais, entre as quais, especialmente os meios de comunicação, nos dias atuais, constituiriam o terceiro nível. "Ideais" promovidos coletivamente, extremamente poderosos, "consumidos" de forma quase que inconsciente influenciariam de maneira significativa as escolhas que fazemos.

Por último, o quarto nível, "macrosistema”, constituído a partir dos valores culturais, seria aquele que, enquanto cultura, traria um legado histórico cujo alcance atingiria a dimensão do consciente e do inconsciente, referendando o que cada sujeito estaria disposto a dar continuidade, acatando ou arriscando, reproduzindo ou transgredindo.

Esses quatro "sistemas" em profunda e constante interação seriam decisivos para as questões relacionadas ao gênero uma vez que contribuiriam para dar sentido às nossas representações sociais e mentais, permeando praticamente todas as nossas relações.

Na conjunção destas perspectivas é que buscamos refletir a respeito dos mecanismos instituídos que sustentam a socialização de gênero dos adolescentes e que nos pareceu ser uma questão bastante pertinente, especialmente a partir da complexidade de significados que estão em jogo.

Assumimos, portanto, que gênero é uma construção extremamente complexa, permeada de expectativas e prescrições praticadas nas mais diversas instituições, ainda que de formas distintas, que acabam por definir certo perfil de "papel" ${ }^{, 17}$ esperado de cada sujeito perante a coletividade.

Dentro do recorte específico deste trabalho buscamos nos aproximar das formas de legitimação dos papéis de gênero entre adolescentes e, de forma ainda mais delimitada,

\footnotetext{
${ }^{17}$ Ainda que possamos concordar, parcialmente, com críticas feitas ao risco da utilização desta terminologia (Lopes Louro, 1997a) enquanto uma possível forma reducionista de análise, que estaria focada apenas nos indivíduos e/ou relações interpessoais, restringindo-se as desigualdades ao âmbito do face a face, ela se aplica para os fins deste trabalho uma vez que o recorte feito para as investigações de campo teve como objetivo identificar os seus aspectos "formativos" durante a adolescência.
} 
daquelas que se constituem, no âmbito das crenças e valores das subjetividades em formação, por intermédio de expectativas e prescrições deles para consigo mesmos e perante seus pares, que nos pareceram significativas para a construção do papel social de gênero.

\section{2. B - Contextualização histórica da temática de gênero}

Como em toda e qualquer manifestação humana, o sujeito sócio-histórico que a empreende está inserido em um contexto que lhe dá parâmetros e referenciais para nortear suas ações.

Também aconteceu assim com a conjunção de fatores que deflagrou o movimento feminista.

Tem-se notícia de insurgências contra a dominação masculina, contra a organização patriarcal $^{18}$ da sociedade, muito anteriores aos anos que compreendem especialmente as décadas de 50 e 60 , no século XX.

No entanto, na conjunção de fatores que reordenaram uma lógica social do elemento masculino como único provedor e definidor dos laços familiares, especialmente no que tange à possibilidade de reprodução fora da organização familiar formal, que se constituiu o momento histórico fundante do movimento feminista e que inaugurou as discussões relativas às questões de gênero.

Até então "ser homem" ou "ser mulher" era simplesmente uma questão determinada em função do sexo biológico.

A partir das primeiras legislações que abriram espaço para a dissolução do casamento, teve início um amplo movimento que instalou a primeira crise explícita dos modelos de famílias patriarcais. Foi esse o primeiro indicador expressivo e público de insatisfação.

Surgiram, então, alternativas aos modelos familiares, distintos dos mais tradicionais, especialmente aqueles em que as mães assumem a responsabilidade por sua prole, por seu arrimo financeiro e pelo apoio emocional da mesma.

Em decorrência desta reorganização, alterando uma lógica estritamente patriarcal, abriu-se espaço para a formação de relacionamentos fora do casamento e, também para a mulher, por iniciativa de interesses especificamente femininos, para o adiamento da formação de casais. Aumentou, significativamente, o número de nascimentos fora da família legalmente instituída e enquadrada dentro dos padrões formais conhecidos.

\footnotetext{
${ }^{18}$ Segundo MACHADO, L. Z. (2000) a organização patriarcal é a presença e a prática da dominação masculina em determinada coletividade.
} 
A instabilidade familiar e a crescente autonomia das mulheres inseriram no viver coletivo uma variável de reivindicações até então desconhecida.

Praticamente no mesmo período, a medicina e a biologia introduziram possibilidades de libertação do corpo feminino do aspecto estritamente reprodutivo de sua sexualidade.

Estas possibilidades de liberação contribuíram para a ratificação das novas demandas e inauguraram, em paralelo, também em relação às oportunidades de trabalho, fronteiras para muito além das "domésticas", praticamente dobrando a contribuição das mulheres na dimensão econômica coletiva.

Assim, a participação das mulheres no mercado de trabalho pode ser entendida como mais um dos importantes fatores constituintes da conjuntura favorável à deflagração do movimento feminista, mesmo porque algumas circunstâncias contribuíram para a explosão da contratação da mão de obra feminina.

Em função do interesse das mulheres em alcançar uma participação coletiva mais representativa há espaços favoráveis para a sua contratação: recebem menos por seu trabalho; há uma maior flexibilidade em relação a esta nova opção de força produtiva. Elas não só estão dispostas, quanto lhes interessa participar de condições de trabalho um tanto quanto diferenciado, admitem e aceitam horários distintos, expedientes flexíveis e trabalho temporário, introduzindo um caráter inusitado ao trabalho formal.

À medida que cresce sua participação, elas passam a colaborar, também, para o orçamento doméstico, dando sua contribuição ao sustento da família, fazendo crescer seu poder de barganha no espaço privado.

Institui-se, assim, a primeira verdadeira rebelião contra a autoridade patriarcal, que Castells (2000) nomeou acertadamente de "sementes feministas". A intensa pressão sobre as variáveis que, historicamente, regeram as sociedades patriarcais foi uma espécie de compromisso público assumido para por fim à dominação masculina. Uma verdadeira tentativa de afirmar-se a igualdade entre homens e mulheres, evidenciando-se a especificidade feminina.

A categoria "gênero" passou, então, a ser uma instância de discussão específica, desvinculada, até certo ponto, das simples determinações biológicas e, portanto assumidas como "naturais", discussão esta relevante e significativa para a história humana, criando espaço para o "feminino".

Esta primeira grande ruptura da "diferença natural entre os sexos", entretanto, ainda que buscando afirmar uma equiparação, permanece basicamente fundamentada sobre a perspectiva de sexo, e continua, portanto, bastante polarizada. 
Um segundo momento especialmente relevante da discussão das questões de gênero, desta vez, como possibilidade de algo não previamente determinado e, portanto, necessariamente "estável" diz respeito à forma como se "faz o gênero", na dimensão da singularidade.

Haveria uma forma única de ser homem ou de ser mulher?

Constata-se aí a insuficiência das discussões de gênero desvinculadas daquilo que se entende pelas variáveis associadas à sexualidade e, portanto, bastante singular a cada individualidade.

A constatação à qual nos referimos, e que didaticamente é aqui tomada como segundo momento das discussões de gênero, é deflagrada pela pandemia da AIDS trazendo novo fôlego às discussões em áreas que se debruçavam sobre questões de gênero, ganhando força em tópicos especialmente relacionados à importância da sexualidade na constituição de uma subjetividade, demonstrando "as limitações de nossos conhecimentos sobre uma ampla gama de tópicos", especialmente "de nosso conhecimento transcultural referente ao comportamento sexual'. (Parker, 1999)

Uma das áreas de discussão que assume tal perspectiva é o "construcionismo social" e que se constitui em campo de debate teórico a partir da articulação de um ensaio de Mary McIntosh, na tentativa de enfrentar questões de identidades sexuais, bastante específicas, que até então não haviam sido contempladas. (Vance, 1995).

Abarca reivindicações de movimentos ativistas, de estudiosos das histórias de vida de gays e de lésbicas, que pretendiam valorizar as manifestações de vida inerentes aos relatos das experiências, também, destes sujeitos.

Os relatos e registros que compõem as narrativas dos indivíduos, em tal ensaio, deixavam evidente que comportamento e identidade não são um único e mesmo fato.

A partir daí abre-se espaço para admitir que atos físicos equivalentes, portanto associados ao sexo e até então em associação direta com o gênero, poderiam ter significados subjetivos bastante distintos. Assim, aquilo que, a princípio, poderia parecer universal para uma cultura e para uma época, demonstrava, no entanto, ter um sentido bastante distinto de sujeito para sujeito.

A sexualidade, sabemos, hoje, envolve simbolismos particulares, significados atribuídos individualmente, e só pode ser compreendida em sua diversidade se, e somente se, dada a devida atenção à pluralidade de opções e escolhas possíveis a cada sujeito.

A institucionalização da heterossexualidade sagrou uma divisão legitimada como padrão de normalidade, gerando uma excessiva polarização da sexualidade, dividindo o 
mundo entre "machos" e "fềmeas". Essa mesma excessiva polarização binária, tipicamente ocidental, marcada nesse caso por uma justificativa biológica, instituiu a homossexualidade como identidade em contraposição ao padrão social esperado, de heterossexualidade, situando a homossexualidade como categoria identitária e, da mesma forma, seu pólo oposto, a heterossexualidade. (Weeks, 2001)

Em um campo propício às disputas ideológicas justificadas por algo tomado como natural "a priori”" corríamos o risco de estabelecer parâmetros identitários rígidos por demais. Diferentes discursos, especialmente de cunho higienista, com raízes em uma possível origem biomédica, adotaram a heterossexualidade como "natural", "normal", tendendo a valorizar excessivamente os atos em detrimento de seu significado, representando uma ameaça no sentido de repatologizar a sexualidade.

Identificou-se então que atos sexuais não poderiam ser equiparados a identidades sexuais.

Essas novas perspectivas fundamentavam, também, as primeiras tentativas feministas de abordar as relações de gênero a partir de uma gama maior de possibilidades.

Compreender como se constitui o intricado jogo social em um contexto cultural específico, freqüentemente justificado a partir de um dado biológico, que se transforma em complexas redes de poder, hierarquias, significados e significações foi um dos desafios ao qual se propôs o "construcionismo social".

A tentativa de simplificar as manifestações das singularidades sempre contou com fortíssimos aparatos de poder e de dominação.

Estas foram conquistas históricas do estudo da sexualidade que contribuíram para a ampliação da discussão.

Foi necessária uma revisão crítica das teorias que se baseavam meramente na reprodução, ou no determinismo biológico, como fator decisivo da constituição da sexualidade; a sexualidade passou a ser admitida como uma variável indispensável às discussões das relações de gênero.

\section{2. C - Evolução conceitual da temática de gênero}

Estudos sobre as vidas femininas - formas de trabalho, corpo, prazer, afetos, escolarização, oportunidades de expressão e de manifestação artística, profissional e política, modos de inserção na economia e no campo jurídico - aos poucos vão exigir mais do que descrições minuciosas e passarão a ensaiar explicações. Se para algumas as teorizações marxistas representarão uma referência fundamental, para outras as perspectivas construídas a partir da Psicanálise poderão parecer mais produtivas. Haverá também aquelas que afirmarão a impossibilidade de ancorar tais análises em quadros teóricos montados sobre uma lógica androcêntrica e que buscarão produzir explicações e teorias propriamente feministas, originando o 
"feminismo radical". Em cada uma dessas filiações teóricas usualmente se reconhece um móvel ou causa central para a opressão feminina e, em decorrência, se constrói uma argumentação que supõe a destruição dessa causa central como o caminho lógico para a emancipação das mulheres.

LOPES LOURO, 1997a, p.20.

Gênero, como campo de estudos e investigações, é uma discussão relativamente recente considerando que são pouco mais de quatro décadas frente às discussões epistemológicas mais tradicionais.

Disto decorre, em parte, o fato de haver enfoques bastante diversos e entendimentos distintos para uma questão em si mesma tão polêmica.

A adoção de um termo, relativamente novo no meio científico, pressupõe um recorte suficientemente específico.

Scott (1995) afirma que um termo, tem em si mesmo, uma história:

Mais recentemente - demasiado recente para que pudesse entrar nos dicionários ou na Encyclopedia of Social Sciences - as feministas começaram a utilizar a palavra "gênero" mais seriamente, num sentido mais literal, como uma maneira de se referir à organização social da relação entre os sexos. (...)

Na sua utilização mais recente, o termo "gênero" parece ter feito sua aparição inicial entre as feministas americanas, que queriam enfatizar o caráter fundamentalmente social das distinções baseadas no sexo. A palavra indicava uma rejeição do determinismo biológico implícito no uso de termos como "sexo" ou "diferença sexual".

O termo "gênero" enfatizava igualmente o aspecto relacional das definições normativas da feminilidade.

(grifos no original) SCOTT, 1995, p. 72.

Gênero foi, portanto, um termo que começou a ser adotado para apontar uma alternativa relacional frente à oposição binária homem/mulher; teve como enfoque central a possibilidade de incluir a experiência feminina na perspectiva histórica da humanidade. Dentro dessa concepção, gênero passou a ser admitido como categoria de estudo, de ordem equivalente à classe e à raça.

Cabe salientar que, enquanto o conceito de classe tem raízes mais evidentes em matrizes de teorias marxistas, cuja sustentação se dá em definições associadas à causalidade econômica, raça e gênero parecem ser categorias menos explícitas.

Gênero, como objeto analítico de estudos específicos, acabou se tornando um terreno de múltiplas perspectivas. Do ponto de vista histórico, as primeiras concepções estiveram mais próximas de "correntes" de pensamento permeadas por questões filosóficas.

Dentro desta linha algumas tendências se fizeram mais influentes.

Como primeira alternativa teórica admitiu-se o conceito de gênero de uma maneira essencialmente descritiva. Scott (1995) afirma que a palavra "gênero" começou a ser empregada pelas feministas como uma forma de se referir à organização social da relação 
entre os sexos, buscando enfatizar um caráter de relativismo frente às distinções baseadas apenas no sexo (estritamente biológico). Nesse sentido pretendiam rejeitar o "determinismo biológico" implícito ao uso de termos como "sexo" ou "diferença sexual".

No seu uso descritivo, o termo "gênero" é, então, um conceito associado ao estudo de coisas relativas às mulheres. "Gênero" é um novo tema, um novo domínio da pesquisa histórica, mas não tem poder analítico suficiente para questionar (e mudar) os paradigmas existentes.

(grifos no original) SCOTT, 1995, p. 76

Uma concepção menos simplificada, ainda dentro da linha descritiva, admitia que gênero, para além de ser um simples termo substitutivo para a expressão "mulher", enquanto a "fêmea" da nossa espécie, incluiria concepções de apreciação relacional, próprias à interação que se estabelece entre homens e mulheres.

Essa abertura teórica, atribuída também às historiadoras feministas, acabou por ampliar as possibilidades da questão, atentando para o fato de que uma abordagem meramente descritiva não teria influência suficiente para alterar nenhuma das lógicas dominantes, presentes às condições sociais.

No segundo estágio do gênero, especialmente significativo entre 1960 e 1970, o biológico foi admitido como a "base" sobre a qual se constroem significados culturais. Diferenças físicas são compreendidas como o eixo a partir do qual se estabelecem as relações de gênero.

Neste sentido, o termo "gênero" passa a ser empregado como complementar à noção de "sexo" e não apenas como seu substituto. Esse seria o período denominado por Nicholson de "fundacionalismo biológico", uma vez que "fundamentos biológicos" coexistem, teoricamente, com as considerações a respeito da influência da construção coletiva de significados a partir do "dado biologicamente".

De acordo com tal perspectiva, corpo, personalidade e comportamento têm certa continuidade; a partir de "constantes" da natureza são admitidas, conseqüentemente, algumas variáveis sociais, que são entendidas como uma espécie de "extensão" daquilo que é "naturalmente fixo".

Há uma tentativa de conciliar perspectivas deterministas com uma abordagem mais abrangente que leva em consideração as conseqüências inevitáveis de uma diferença assumida como inquestionável.

Para esta última tendência houve três possíveis inclinações. 
A primeira, inteiramente feminista, associou as relações de poder inerentes ao gênero exclusivamente a questões do patriarcado ${ }^{19}$. Essa abordagem tendeu a simplificar o tema em uma associação direta com as diferenças meramente físicas e biológicas, historicamente arraigadas em uma lógica de dominação sem atentar para as construções simbólicas.

Outra situa as suas concepções em estreita correlação com a tradição marxista, associando seus pressupostos em fundamentos das relações de poder estabelecidas a partir do trabalho. Tentando encontrar uma explicação "material" sempre associada aos "modos de produção" tem restringido a possibilidade de outras perspectivas, menos arraigadas, nas estruturas sócio-econômicas.

Por fim, uma terceira tendência de abordagem, possivelmente mais abrangente, está inspirada na teoria psicanalítica e busca compreender os processos pelos quais a identidade de um sujeito é constituída.

Esta última, inspirada nos pressupostos da Psicanálise, subdividiu-se em duas correntes, uma da escola anglo americana mais fundamentada na possibilidade de atribuir à experiência concreta do sujeito a significação de seu papel social, como mulher ou como homem, e outra da escola francesa, que entende que tal constituição se dê fundamentalmente por intermédio da linguagem.

No caso dos estudos da Psicologia Moral, foi a escola anglo-americana que demonstrou ter uma maior influência sobre tais estudos, uma vez que Gilligan, considerada pertencente a essa corrente feminista, trouxe importantes contribuições ao inaugurar as discussões que romperam com as concepções de moralidade, baseadas unicamente no princípio masculino da justiça ${ }^{20}$.

Partindo de investigações que se propuseram a superar os impasses dos estudos clássicos a respeito da moralidade, e que, ainda segundo Gilligan, estariam "emolduradas" pelos pressupostos do patriarcalismo vigente, a proposta foi identificar outras variáveis que pudessem afetar a formação moral das singularidades, especialmente naquilo que ela chamou de "voice in relationships". (Gilligan, 2003)

Considerando haver um consenso mínimo de que gênero seja substancialmente uma noção relacional, "conter", por intermédio de mecanismos conscientes ou inconscientes, a relevância de uma de suas "vozes", nas mediações próprias das relações interpessoais, seria,

\footnotetext{
${ }^{19}$ Segundo NARVAZ, M. G. \& KOLLER, S. H. (2006), o patriarcado é uma forma de organização social na qual as relações são regidas por dois princípios básicos: 1) as mulheres estão hierarquicamente subordinadas aos homens; e, 2) os jovens estão hierarquicamente subordinados aos homens mais velhos. A supremacia masculina ditada pelos valores do patriarcado atribuiu um maior valor às atividades masculinas em detrimento das atividades femininas; legitimou o controle da sexualidade, dos corpos e da autonomia femininas; e, estabeleceu papéis sexuais e sociais nos quais o masculino tem vantagens e prerrogativas (Millet, 1970; Scott,1995).

${ }^{20} \mathrm{O}$ princípio da justiça como pressuposto da moralidade é tema de discussão no item II.1.C
} 
segundo esta concepção, uma forma de instituir um desequilíbrio na origem das interações entre os indivíduos, extremamente significativo para a experiência e constituição do psiquismo feminino que acabaria, de algum modo, se estendendo para o coletivo, como parâmetro na constituição da legitimidade de sua representatividade social.

Para Nicholson (2000), no entanto, as diferenças nas perspectivas de abordagem das questões de gênero estariam unicamente arraigadas no quociente de diferenciação biológica considerado. De um estágio inicial, muito próximo àquilo que conceitua o masculino e o feminino como mero atributo decorrente da própria constituição física (biologicamente assentado) nomeado por "determinismo biológico" a estágios mais elaborados de significação dos corpos a partir das construções simbólicas, as teorias de gênero estariam buscando dentro desta concepção a sua independência de qualquer tipo de determinismo (ou "apriorismo") na formulação das suas linhas teóricas.

Resumidamente poderíamos recorrer às considerações de Negueira (2001) para explicitar as principais tendências teóricas assumidas como uma forma de "naturalização" da diferença entre os gêneros.

\begin{abstract}
A primeira abordagem essencialista, que prevaleceu entre os psicólogos, na primeira metade do século XX, sugere a existência de diferenças inatas e estáveis entre os sexos, conceituando o gênero (ou sexo, que, nessa perspectiva, são praticamente equivalentes) como uma propriedade estável, inata e bipolar de diferenciação sexual, tendo um caráter eminentemente determinista. As visões essencialistas além de entenderem o gênero como uma propriedade estável, consideram-no como um traço que descreve as personalidades, os processos cognitivos, o julgamento moral etc. (Bohan, 1997). Dessa maneira, os modelos essencialistas concebem o gênero em termos de atributos fundamentais, concebidos como internos, persistentes (Burr, 1998) e, geralmente, separados das experiências quotidianas de interação com outros contextos sociopolíticos. Desse modo, muitas vezes o essencialismo é interpretado e compreendido como determinismo biológico (Bohan, 1997), pois, no que diz respeito ao gênero, advoga um posicionamento que define a natureza feminina e masculina expressas em diferenças de personalidade, preferências profissionais, desejo de paternidades etc. (Burr, 1998).
\end{abstract}

A segunda abordagem desse programa empiricista pode ser considerada como a da socialização, que dominou a psicologia social durante os anos 60 e 70; aqui move-se o foco de atenção, relativo ao gênero, da biologia para a socialização. $O$ gênero passa a ser concebido, não como inato, mas como o resultado de forças sociais e culturais, aprendido por intermédio dos processos de modelagem e imitação (Bandura, 1977). As crianças, ao aprenderem a internalizar prescrições apropriadas para o ser masculino ou feminino de acordo com as normas da sociedade, formam personalidades e padrões de comportamento enquadrados no gênero. Depois de formada, a personalidade é concebida como característica individual estável e inerente aos indivíduos. Assim, a masculinidade e a feminilidade passam a ser características socialmente aprendidas pelo desenvolvimento cognitivo e emocional.

(grifos no original)

NEGUEIRA, 2001, p. 140.

Ainda segundo Negueira, apoiando-se na postura "essencialista", das diferenças inatas ou aprendidas, foi sendo instituída uma "potente retórica da verdade” que, gradativamente, "foi construindo a 'verdade' sobre gênero". 
A perspectiva determinista, em sua vertente socializante, admitiu gênero como um aprendizado de papéis sociais; homens e mulheres por não ter representatividade social equivalente acabariam por adquirir competências sociais distintas.

Dentro de tais concepções, denominadas por algumas de seus críticas (Scott, 2005; Negueira, 2001; Nicholson, 2000) de "essencialismo", correr-se-ia o risco de permanecer no "papel de simples cronista da realidade" em um distanciamento tipicamente cartesiano no âmbito daquilo que não ultrapassa o diagnóstico e que se exime de toda "responsabilidade e de todo o compromisso".

Continuando com as considerações de Negueira, essa proposição apesar de considerar a possibilidade de assumir aquilo que as mulheres têm em comum, parece não ter contemplado aquilo que as distingue em sua singularidade.

No entanto, ao retomar as discussões propostas por Gilligan haveria uma possibilidade de considerar que, ainda que as representações coletivas pudessem ter um ponto de partida comum para meninas e meninos, de difícil comprovação na prática, cada individualidade, em função das experiências pelas quais passa, durante a constituição de sua subjetividade, faria uma espécie de "leitura" singular destas "prerrogativas".

Para muitos estudiosos da temática, esta concepção foi considerada ainda muito limitada para dar conta da diversidade de uma forma mais ampla, especialmente entre aqueles que pretenderam incluir em suas reflexões o entendimento de que a sexualidade de cada indivíduo pode permitir distintas formas de agir e de atuar, de acordo com o contexto e as circunstâncias.

\begin{abstract}
Através da crença comum de que a "identidade sexual" representa o ponto comum entre várias culturas, freqüentemente generalizamos o que é específico da cultura moderna ocidental ou de certos grupos dentro dela. Mais do que isso, tem sido difícil identificar essa generalização equivocada como tal, por causa da aliança de todas as formas de fundacionalismo biológico com o construcionismo social. As feministas há muito vêm percebendo como argumentos relativos a explicações biológicas para personalidade e comportamento generalizam equivocadamente aspectos específicos da personalidade.
\end{abstract}

De acordo com esta visão, as concepções anteriores assumiriam que as relações de gênero seriam fundamentadas em diferenças "naturalizadas", determinadas ou aprendidas, razão pela qual muitos autores as consideram pertencentes a uma mesma tendência teórica.

Negueira faz uma crítica a esta forma de fundamentar as questões de gênero, pois entende que a mesma não chega a superar o "dualismo clássico", mantendo "conceitos convencionais de masculinidade e feminilidade" muito próximos às explicações naturais.

(...) essa abordagem enfatiza que o gênero é aprendido e não inato, mas continua a definir gênero em termos de diferença dicotômica. Dessa forma, a distinção entre 
inato e aprendido, em certa medida, é meramente semântica, já que a socialização de gênero é concebida como algo específico e persistente ao longo do ciclo da vida. Assim, em termos práticos, o gênero continua a ser visto como interno e imutável. Por esta razão Janis Bohan (1997) designa por essencialistas ambas as abordagens, considerando como asserção básica da perspectiva essencialista a idéia do gênero como característica permanente e estável dos indivíduos.

NEGUEIRA, 2001, p.141.

Entendemos, no entanto, que há espaço para compreender a socialização de gênero como um processo extremamente significativo em alguns momentos mais específicos da formação das novas gerações e que nestes períodos os modelos vigentes ou predominantes têm um caráter de influência muito mais marcante. Não são modelos determinantes, necessariamente fixos, mas subsidiam as percepções das individualidades em sua leitura de mundo, dialogando com as mais distintas e possíveis perspectivas que possam surgir.

A vertente mais crítica a este posicionamento entendeu que a partir das evidências de que ainda que houvesse "determinações orgânicas primitivas", e mesmo que coletivamente fossem criadas e admitidas condições específicas de acordo com o "dado biologicamente", cada sujeito poderia criar simbolismos particulares de sua "constituição" e "condição social", alertando para o fato de que abordagens complementares se fariam necessárias.

De um lado, o "gênero" foi desenvolvido e é sempre usado em oposição a "sexo", para descrever o que é socialmente construído, em oposição ao que é biologicamente dado. Aqui, "gênero" é tipicamente pensado como referência a personalidade e comportamento, não ao corpo; "gênero" e "sexo" são portanto compreendidos como distintos. De outro lado, "gênero" tem sido cada vez mais usado como referência a qualquer construção social que tenha a ver com a distinção masculino/feminino, incluindo as construções que separam corpos "femininos" de corpos "masculinos".

(grifos no original)

SCOTT, 2005, p. 9.

O desafio passou a ser, então, superar o entendimento de gênero em associações diretas, fosse por intermédio do "determinismo biológico" ou do "fundacionalismo biológico" e buscar outras perspectivas.

Tais discussões permitiram que a temática fosse abordada por algumas áreas distintas do conhecimento tais como a Psicologia, a Sociologia, a Antropologia, entre outras.

No caso da Psicologia Social, o "construcionismo social" foi uma das vertentes que buscou explorar a diversidade enfocando-a a partir das variáveis da sexualidade, nas relações de gênero.

Uma de suas prerrogativas seria, buscando superar a tendência do pensamento ocidental de polarizar os sujeitos necessariamente em dois extremos, romper com a lógica de que os sujeitos sejam necessariamente vítimas ou algozes em suas relações; mais uma vez em uma distinção bastante polarizada. 
Para tal corrente somos detentores de possibilidades de escolhas, ainda que sejam estas, fruto de um repertório de opções constituído coletivamente.

Mais do que uma questão de determinismo biológico ou social a abordagem que se propõe dentro desta linha teórica é a de que o gênero seja uma construção "performática" do sujeito, que supera a dicotomia entre homem/mulher, "machos" ou "fêmeas" da espécie.

Esta "performance" ${ }^{21}$, segundo os teóricos, resulta de escolhas feitas pelo sujeito a partir de um repertório de opções, que não são, necessariamente, apenas aquelas estabelecidas no coletivo e portanto, socialmente determinadas.

Como sujeitos histórico-culturais somos seres mutantes, em permanente estado de transformação, construtores e construções inacabadas de nossa própria individualidade. O construcionismo social permite que se coloquem novas questões (Crawford, 1995;
Hare-Mustin, Marecek,1990), tais como: como é que o gênero é produzido e
sustentado pelos agentes humanos em interação uns com os outros? por meio de que
estruturas institucionais, práticas sociais e representações culturais, códigos
lingüísticos e padrões de inter-relação social o gênero torna-se um fato social?
quando é que determinada definição de gênero exerce um mecanismo de controle
social? por que é que só algumas definições de gênero são incorporadas à nossa
identidade? o que leva os indivíduos a resistirem a determinadas definições de
gênero em circunstâncias particulares?

NEGUEIRA, 2001, p149.

Segundo a autora, rompe-se com os "estudos das mulheres" que simplesmente apelam para uma "potente retórica da verdade" muito fundamentada no mito da objetividade, introduzindo inúmeras possibilidades de compreender o fenômeno sob a ótica da diversidade e da complexidade intrínseca a cada subjetividade.

Dessa forma admite-se uma possibilidade de superação da perspectiva tradicional positivista que procurou estabelecer parâmetros sempre fixos, imutáveis, para a análise de fenômenos complexos, rompendo também com algumas "teorias psicológicas" que "freqüentemente excluem as mulheres ou distorcem as suas experiências" (Negueira, 2001).

Passa-se a considerar, também, a possibilidade de que cada sujeito possa fazer uma espécie de "apropriação" particular das circunstâncias próprias às suas interações, sempre singulares, no lugar social que ocupa, permitindo introduzir a perspectiva de uma “interpretação" subjetiva de cada indivíduo que não caberia, obrigatoriamente, em categorias únicas e necessariamente fixas.

Defendo que a população humana difere, dentro de si mesma, não só em termos das expectativas sociais sobre as quais pensamos, sentimos e agimos; há também diferenças nos modos como entendemos o corpo. Conseqüentemente, precisamos entender as variações sociais na distinção masculino/feminino como relacionadas a diferenças que vão até o fundo - aquelas diferenças ligadas não só aos fenômenos limitados que muitas associamos ao "gênero" (isto é, a estereótipos culturais de personalidade e comportamento), mas também a formas culturalmente variadas de se

\footnotetext{
${ }^{21}$ Terminologia freqüente na linguagem do "construcionismo social" na Psicologia Social.
} 
entender o corpo. Essa compreensão não faz com que o corpo desapareça da teoria feminista. Com ela o corpo se torna, isto sim, uma variável, mais do que uma constante, não mais capaz de fundamentar noções relativas à distinção masculino/feminino através de grandes varreduras da história humana, mas sempre presente como elemento potencialmente importante na forma como a distinção masculino/feminino permanece atuante em qualquer sociedade.

(grifos no original)

NEGUEIRA, 2001, p. 145.

Gênero seria, portanto, uma concepção complexa da qual participariam inúmeras variáveis, não se esgotando apenas nos atributos mais evidentes.

As implicações daquilo que defendem autoras como Negueira, Nicholson, entre outras, permitem atentar para o fato de que o reconhecimento das diferenças inerentes às constituições corporais assuma significações distintas, de grupo para grupo, cuja representação afetará a constituição das singularidades de forma bastante específica.

Compreender as diferentes concepções que permeiam as interpretações e representações individuais e coletivas pode abrir caminhos, especialmente, quando se pretende ir além do diagnóstico e da atuação a partir das conseqüências, para buscar causas que possam contribuir para o "modelo cultural" da desigualdade no Ocidente e que, de algum modo, se manifestam por intermédio da naturalização de disparidades, presentes também nas representações de gênero.

Há, porém, que se evidenciar que, em muitos casos, as questões de gênero não deixam de ser um discurso das ciências, ainda muito influenciado por raízes positivistas, e que, é preciso estabelecer como ponto de partida um distanciamento de qualquer caráter de questões de gênero enquanto uma temática limitada apenas a uma perspectiva feminina uma vez que este caráter permanece enviesado pelos "princípios positivistas da objetividade".

As linhas teóricas de vanguarda entendem que a superação ao "determinismo essencialista" vem ocorrendo por intermédio do que chamam de "terceira abordagem" ou "terceira vaga". Desta forma, por um lado, sexo e gênero não são aqui tomados como opostos e nem
mesmo como complementares, pois 'a sociedade não apenas forma a personalidade
e o comportamento, ela também determina as maneiras nas quais o corpo é
percebido. Mas se o corpo é ele próprio sempre visto por meio da interpretação
social, então o sexo não é alguma coisa separada do gênero, mas, ao contrário, é algo
subsumido no gênero' (NICHOLSON, 1994: 79). Uma tal compreensão nos permite
perceber variações históricas e culturais tanto no que se refere a padrões culturais de
personalidade e comportamento, quanto na compreensão do corpo, da sexualidade e
daquilo que significa ser um homem ou uma mulher.

CARVALHO, 2008, p. 92.

A terceira via, como bem nos aponta Carvalho, traz à discussão a relevância de reconhecermos a fluidez com que se constrói o gênero, sempre cultural, social, temporal e historicamente situado. 
Por outro lado, potencializa-se a utilização do gênero na análise da sociedade como um todo, não apenas no que se refere às mulheres, ao parentesco e à sexualidade, mas também à dimensão econômica e política e às vidas dos homens tanto quanto das mulheres. Esse enfoque provém especialmente das estudiosas do pós estruturalismo, tais como Joan Scott (1990: 1992; 1994) e Linda Nicholson (1994), que enfatizam a necessidade de uma atenção às linguagens e ao papel das diferenças percebidas entre os sexos na construção de todo sistema simbólico, especialmente na significação das relações de poder.

CARVALHO, 2008, p. 92/93.

Há que se considerar, ainda, que, ao introduzir estas variáveis aos estudos e pesquisas que pretendam se dedicar ao tema, variáveis das questões de gênero passam a permear praticamente todas as questões cotidianas das relações que se estabelecem entre os indivíduos.

\begin{abstract}
Para essas autoras, os significados seriam construídos a partir da observação da diferença e do contraste; e a diferença sexual seria 'um modo principal de dar significado à diferenciação’ (SCOTT, 1990: 16). A partir da observação da diferença sexual na natureza, diversos significados culturais são construídos, as diferenças entre masculinidade e feminilidade sendo utilizadas como um meio de decodificar o sentido e compreender o universo natural e humano observado: 'Estabelecidos como um conjunto objetivo de referências, os conceitos de gênero estruturam a percepção e a organização concreta e simbólica de toda a vida social' (SCOTT, 1990: 16).
\end{abstract}

CARVALHO, 2008, p. 93.

Entendida como um "projeto psicológico feminista pós-moderno" a proposta desta linha teórica situa-se no sentido de recomendar que "o conhecimento científico necessita ser compreendido como poder social, não como leis universais ou parcelas de afirmação da verdade." (Negueira, 2001)

Se, por um lado, estas possibilidades enriquecem as reflexões de seus especialistas, trazendo novas variáveis às discussões, podem, por outro lado, gerar uma espécie de "rigidez às avessas" ao sugerir que outras formas de leitura da temática sejam por demais simplistas, de algum modo, suplantadas. As criticas mais pertinentes a essa abordagem, a meu ver, apontam os perigos de
uma análise restrita às linguagens, incapaz de abranger igualmente as práticas
sociais; e certa tendência a tomar as estruturas das linguagens como um sistema de
controle $a$ priori, inacessível à intervenção dos agentes (VARIKAS, 1994). Acredito
ser possível, contudo, absorver as contribuições postas em primeiro plano pelas
feministas pós-estruturalistas - como a atenção ao gênero como construção mutante
de significados - sem perder a referência às práticas sociais e às possibilidades de
ação dos sujeitos.

CARVALHO, 2008, p. 94.

As concepções por nós adotadas tiveram por pressuposto o fato de que gênero seria uma questão sem resposta fixa, estável, em si mesma, mas fruto de um processo de construção contínua e interminável do sujeito para consigo mesmo, em interação com as demais instâncias que influenciam a sua forma peculiar de se relacionar consigo mesmo e com os demais.

Há, portanto, uma infinidade de perspectivas a adotar para as investigações que se pretendam legítimas e que permitam ampliar as questões que, por ora, estão postas. 
(...) Numa perspectiva construcionista social é importante a desconstrução, a democratização e a reconstrução de novas realidades e práticas para a transformação cultural (Gergen, 1994).

NEGUEIRA, 2001, p.149.

Entendemos que as diferentes propostas de abordagem para as questões de gênero não são obrigatoriamente irreconciliáveis, mas permitem um diálogo na conjunção daquilo que trouxeram como contribuição mais significativa para a discussão, abrindo espaços para a revisão e a reconstrução constante daquilo que está em permanente transformação, próprio das subjetividades, inerente à diversidade em si mesma.

Estudos relacionados ao gênero se constituem em um território acadêmico que viabiliza a inovação e a transformação, a revolução própria daqueles que buscam as questões subjacentes àquelas mais evidentes e óbvias de fenômenos tão complexos quanto as próprias singularidades em questão.

\section{2. D - Concepções adotadas}

O uso do conceito de gênero ultrapassou seu âmbito acadêmico e multidisciplinar (antropologia, sociologia, história, ciência política, lingüística, literatura, filosofia, psicologia...), e seu âmbito de utilização nos estudos feministas. Ganhou espaço legítimo e consolidado na circulação internacional no campo dos direitos humanos e na formulação de projetos de políticas públicas nos mais diversos âmbitos. Como conceito presente no campo político, suas referências se tornam mais flutuantes, conforme o contexto. Críticas começam a ser feitas, ora por não ser exclusivamente acadêmico e analítico mas também político, ora por estar sendo banalizado e enfraquecido no campo político.

MACHADO, 2000, p. 2.

As palavras, tanto quanto os conceitos que delas decorrem, fazem parte de um sistema abrangente que integra toda a nossa comunicação.

São recursos de significação compartilhada de mundo que nos permitem socializar nossa interpretação particular dos fenômenos e, na medida do possível, oferecem alternativas de adotarmos novas perspectivas e ampliar as nossas representações.

Se é fato que possam gerar e mediar o entendimento, abrem outras tantas possibilidades para múltiplas interpretações. Por vezes até, um tanto quanto distorcidas...

Palavras poderão ser empregadas para elaborar conceitos, delimitando recortes adotados ou para a banalização de concepções que demandariam definições mais específicas. Poderão subsidiar um sentido genérico para uma primeira aproximação de um termo ou permitirão sua aplicação a áreas de conhecimento que exigem uma demarcação das fronteiras aceitáveis para a discussão. Poderão requintar ou vulgarizar o emprego que delas fazemos... 
Neste sentido, compreender o seu uso, traduzido em termos específicos de determinadas áreas do conhecimento, é fundamental para delimitar o campo conceitual a partir do qual falamos.

A terminologia que adotamos, a partir da nossa discussão temática central, pautada nas questões de gênero pressupõe que nos aproximemos das possibilidades de significação das expressões mais utilizadas pelos especialistas desta área, remetendo-nos, portanto, especialmente ao significado adotado para os termos gênero, sexualidade e sexo.

Optamos por iniciar a discussão a partir daquele que nos pareceu permitir uma aproximação mais clara e mais direta - sexo -, seguido por aquele que, ainda que seja tão fluido quanto o terceiro não configurou o eixo central de nosso trabalho - sexualidade -, finalizando o presente item com a concepção que de fato foi e tem sido o foco das nossas inquietações - gênero - e a partir das quais se originou a presente pesquisa.

Uma primeira aproximação para quem pretende compreender um termo desconhecido anteriormente - e talvez a forma mais legítima - será por intermédio dos sinônimos oferecidos pelos dicionários de nossa língua.

Sexo: 1 no Homem, conformação física, orgânica, celular, particular que permite distinguir o homem e a mulher, atribuindo-lhes um papel específico na reprodução 2 nos animais, conjunto de características corporais que diferenciam, numa espécie, os machos e fêmeas e que lhes permite reproduzir-se.

Dicionário Houaiss da Língua Portuguesa.

Este entendimento inicial, por demais abrangente, oferece um significado tanto mais influente quanto maior a distância das condições efetivas de superação de suas restrições, exigindo de nossa parte uma exploração complementar e possibilitando-nos remeter às discussões feitas anteriormente.

Assim, optamos por citar algumas das definições atinentes ao termo de autores consagrados, na discussão temática referente às questões de gênero.

Vance (1995) define sexo como um sistema simplificado de evidências, facilmente identificável, associado à reprodução e ao determinismo biológico.

Madeira (1996a) associa sexo a uma condição biológica, ou seja, à diferenciação entre um macho e uma fêmea.

Weeks (2001) entende que sexo é um termo descritivo, associado a diferenças anatômicas básicas que permitem a distinção entre homens e mulheres.

Adotamos, portanto "sexo" como sendo o termo descritivo de características orgânicas, constituídas a partir de uma determinação genética.

Esta conformação física permite, no entanto, que cada individualidade assuma este corpo de maneiras distintas inferindo-lhe significados próprios. 
Sexualidade: 1 qualidade do que é sexual $\mathbf{2}$ conjunto de caracteres especiais, externos ou internos, determinados pelo sexo do indivíduo 4 PSICN conjunto de excitações e atividades, presentes desde a infância (de um indivíduo) ligados ao coito, assim como aos conflitos daí decorrentes.

Dicionário Houaiss da Língua Portuguesa.

Também este termo, que nos apresenta um caráter bastante genérico e aparentemente determinante em nossa língua, permite aproximações conceituais com o recorte específico do objeto central de nosso trabalho.

Moore (1997) afirma que muitas das distinções empregadas no campo da sexualidade têm se utilizado de um modelo nativo ocidental, baseado na reprodução humana que assume como natural a diferença entre homens e mulheres.

Para esta autora "sexo", enquanto condição meramente física, é entendido como característica comum a seres organicamente equivalentes enquanto "Sexo" (aqui tomado como a sexualidade) é o "sexo" que se torna próprio de cada subjetividade. São sistemas distintos profundamente interdependentes. Construções de sentido cultural tornam impossível a existência do "sexo" sem "Sexo". "Sexo" seria um sistema simbólico que nos permite vivenciar e compreender o "sexo" como parte da constituição de um corpo marcado por diferenças físicas, cujo significado é atribuído socialmente.

O conceito de sexualidade adotado é derivado das ciências sociais, expresso em um
conjunto de regras sócio-culturais que modelam a experiência íntima dos sujeitos no
ocidente moderno. Sua articulação com o conceito de gênero é essencial, visto ser
um sistema de classificação social que organiza contrastivamente os atributos
masculinos e femininos em diferentes sociedades. Assim, as experiências
particulares de homens e mulheres no tocante à sexualidade e à reprodução só
podem ser consideradas à luz das diferenças de gênero que conformam as
representações e práticas masculinas e femininas em cada cultura. BRANDÃO \& HEILBORN, 2006, p.1422.

Weeks (2001) afirma que a sexualidade é um construto social, historicamente modelado, que abrange crenças, comportamentos, relações e identidades, socialmente construídas.

Complementando, para Parker (1994) "a vida sexual molda-se menos no singular do que no plural - é moldada por diversas instituições, bem como por seus discursos culturais, múltiplos e freqüentemente contraditórios".

Para os fins deste trabalho assumimos, portanto a sexualidade como sendo o significado atribuído por cada individualidade a uma condição definida geneticamente, moldada por representações coletivas e carregada de simbolismos e interpretações singulares. São opções individuais legitimadas por códigos de pertencimento que subsidiam mecanismos de atração e de escolhas traduzidas em atos, condutas, comportamentos e relações. 
A sexualidade é entendida, portanto, como uma dimensão particular de atribuição de sentido às experiências e vivências do sujeito que não são previamente determinadas e, muito menos definitivas.

As mesmas representações coletivas que afetam as formas de se posicionar perante as possibilidades de se estar "sexuado" no mundo é que sustentam lógicas sociais que tendem a generalizar a expressão daquilo que é único, de forma marcadamente normatizante.

Gênero: 1 conceito geral que engloba todas as propriedades comuns que
caracterizam um dado grupo ou classe de seres ou de objetos 2 p. ext. conjunto de
seres ou objetos que possuem a mesma origem ou que se acham ligados pela
similitude de uma ou mais particularidades $\mathbf{2 . 1}$ p. ext. tipo, classe, espécie, estilo 9
GRAM LING categoria das línguas que distingue classes de palavras a partir de
contrastes como masculino/feminino/ neutro, animado/inanimado, contável/não
contável etc; nas línguas a distribuição das palavras nessas classes pode coincidir em
parte com uma distinção semântica como p. ex. a distinção de sexos, pela qual a
classe de palavras designando machos é gramaticalmente masculina, e a classe de
palavras designando fêmeas é gramaticalmente feminina (p. ex. cavalo e égua) mas
as palavras podem tb. entrar numa ou noutra classe gramatical por critérios
convencionais, como se vê, p. ex. em garfo (masculino) e faca (feminino) onde não
é pertinente a distinção natural entre os sexos.

Dicionário Houaiss da Língua Portuguesa.

Especificamente, a concepção de gênero, no escopo deste trabalho, assume seu caráter relacional e político reafirmando a sua complexidade.

(...) No conceito de gênero inclui-se a dimensão psicológica e social do sexo (isto é, as características atribuídas à feminilidade e à masculinidade e os papéis que desempenham homens e mulheres em uma determinada sociedade).

MADEIRA, 1996c, p. 75.

Vance (1995) afirma que sexo e gênero são sistemas distintos. Sexo traz em si mesmo um sistema referencial fixo, enquanto o gênero é um sistema relacional, baseado em questões que envolvem aquilo que, supostamente, pertenceria a um universo feminino ou a um universo masculino.

A autora afirma, ainda, que "gênero" é um sistema que envolve relações de hierarquia e de poder que partem da naturalização de distinções, cuja raiz primária é biológica. De acordo com este entendimento, tal fenômeno decorre da confusão conceitual da sexualidade como categoria secundária em relação ao gênero e mesmo que gênero e sexualidade estejam muitas vezes "entrelaçados em muitos pontos", são distintos.

Embora os membros de uma cultura vivenciem esse entrelaçamento como natural, sem costuras e orgânico, os pontos de conexão variam historicamente e nas diversas culturas. Para os pesquisadores da sexualidade, a tarefa não consiste apenas em estudar as mudanças na expressão do comportamento e atitudes sexuais, mas em examinar a relação dessas mudanças com alterações de base mais profunda no modo como o gênero e a sexualidade se organizam e inter-relacionam no âmbito de relações sociais mais amplas.

VANCE, 1995, p. 12. 
Em uma linha de raciocínio similar, Moore (1997) alerta para a importância de se distinguir além das concepções de "sexo" (comum) e "Sexo" (próprio), também "gênero". Nesta complexa rede de significações é fundamental considerar que, em nossa cultura ocidental, tipicamente binária e polarizada, o conceito de um está a sustentar o outro.

Para esta autora, a importância de se distinguir o sistema "Sexo" do sistema "gênero" seria uma das formas de denúncia da naturalização das diferenças cuja origem é socialmente instituída. Segundo a mesma autora, "gênero" é uma construção simbólica, coletiva que inclui as relações de poder desta decorrente e que de algum modo sustentam desigualdades. Entende que ao pontuar as muitas nuances da distinção entre os dois sistemas possamos contribuir para denunciar hierarquias estabelecidas, naturalizadas por intermédio de justificativas biológicas, que permitem a continuidade de possíveis interesses subjacentes à manutenção de um "status quo".

Weeks (2001) entende gênero como um conceito cuja referência é a diferenciação social que se faz entre homens e mulheres, e a partir da qual se instalam mecanismos sociais geradores da igualdade ou da desigualdade.

Dentre as muitas concepções possíveis de gênero parece haver um consenso de que este seja uma construção relacional que instituiu o masculino e o feminino como forma de estabelecer parâmetros e hierarquias para a lógica social.

Mais recentemente, o entendimento de gênero tem incorporado outras perspectivas que apontam para sua extensão em diversas instâncias das interações, na coletividade, permeando, praticamente, todo o tecido social.

\begin{abstract}
Para as autoras ligadas ao pós-estruturalismo, portanto, o gênero não é um conceito que apenas descreve as interações entre homens e mulheres, mas uma categoria teórica referida a um conjunto de significados e símbolos construídos sobre a base de percepção da diferença sexual e que são utilizados na compreensão de todo o universo observado, incluindo as relações sociais e, mais particularmente, as relações entre homens e mulheres. Esse código pode também servir para interpretar e estabelecer significados que não têm relação direta com o corpo, com a sexualidade, nem com as relações entre homem e mulher, categorizando, em termos de masculino e feminino, as mais diversas relações e alteridades da natureza e da sociedade, conforme cada compreensão cultural e histórica (CARVALHO, 1999).
\end{abstract}

CARVALHO, 2008, p. 93/94.

Alinhavando estas diversas concepções entendemos que gênero deva ser compreendido como uma das formas mais embrionárias de subsidiar a leitura de mundo e que acabou por estabelecer estatutos assumidos como determinantes e deterministas, instituindo a polaridade entre os elementos femininos e masculinos.

Assumir este caráter para as questões de gênero exige uma constante vigilância no sentido de denunciar a relativa "naturalização" das distinções que, historicamente, tem permitido uma série de distorções, considerando a possibilidade de que possam ser revistas e 
reconstruídas, constante e continuamente, buscando efetivamente a sua superação, especialmente no que tange à discriminação e/ou desigualdade delas decorrentes.

Gênero é, portanto aqui tomado como uma forma de compreender e interpretar o mundo a partir das relações que se estabelecem entre o feminino e o masculino, subsidiado ou não, por orientações genéticas, tanto quanto pelas interações cuja origem está nas opções singulares de cada sujeito ao se posicionar de forma sexuada, perante a coletividade influenciada pelas formas como se construíram e se estruturaram, historicamente, as diversas instituições na sociedade.

Adotamos em nosso trabalho que, ainda que na instância do subjetivo nada seja definitivo, fixo e imutável, há momentos em que as opções e as escolhas dos indivíduos, e em nosso recorte falamos das preferências de gênero, são mais fortemente influenciadas em estatutos legitimados pela coletividade, especialmente como uma forma de inserção e aceitação entre pares, tanto mais significativa quanto menor seja o repertório de possibilidades que permita navegar com autonomia diante de estatutos e modelos vigentes.

A vulnerabilidade social e geracional, são, portanto variáveis a serem consideradas quando do recorte em investigações com jovens de camadas populares urbanas que acabam por afetar as nossas "verdades científicas".

\section{2. E - Socialização de gênero}

Segundo a enciclopédia "Gender and Education", diferentes teorias, em diversos campos do saber legitimado, têm se constituído a partir das relações de gênero, mas nem todas podem, de fato, ser aplicadas às questões educacionais.

Embora tenha sido na convergência dos estudos de gênero e educação que tenhamos buscado os referenciais para subsidiar a fundamentação teórica e a análise dos dados obtidos, durante a nossa pesquisa de campo, há que se considerar que, mesmo entre as discussões acadêmicas que têm se mostrado mais apropriadas aos estudos e pesquisas, centrados na confluência de ambos os campos de interesse, encontramos alguns pontos de divergência.

Not every theory of education concerns itself with gender, and some theories of gender have nothing to say about education. (...) This does not mean that they all define education and gender in the same way or that they give equal attention to education and gender. Instead, what makes these theories important and exciting are the different ways in which they conceptualize education and gender and their relationships. These differences, in turn, have implications for how gender inequalities are understood, for the role of education in maintaining or undermining those inequalities, and for the ways in which equity or equality without gender might be achieved.

${ }^{22}$ BANK, Barbara J. ed., 2007. 
Entre as teorias consideradas relevantes na abordagem da interface educação/gênero, no recorte adotado interessaram-nos especialmente as da socialização de gênero e do construcionismo social em virtude de suas vertentes, focadas nos processos de aprendizagem e/ou construção de significados e representações individuais e coletivos.

A primeira em função de sua convergência com os preceitos da Psicologia Moral, outro eixo temático da nossa discussão teórica, por assumir que os processos de aprendizagem, formal ou não, apresentam-se como estruturantes para as interações entre os indivíduos e destes para com as instituições às quais aderem; enquanto a segunda por ter se demonstrado extremamente frutífera, no que tange às discussões da constituição das subjetividades como uma construção singular de significados relativos às relações de gênero na instância da(s) identidade(s).

Ainda que, para alguns estudiosos, a socialização de gênero e o construcionismo social adotem posições aparentemente incompatíveis, com relação à rigidez ou fluidez, respectivamente, das posições assumidas perante o feminino e o masculino, entendemos que seja possível adotar suas contribuições no diálogo de perspectivas que permeiam a forma como cada singularidade dá sentido à sua própria trajetória.

Vale ressaltar que adotamos aqui a "impermanência", defendida pelo construcionismo social como uma forma de imputar flexibilidade à aparente rigidez dos preceitos da socialização de gênero. Consideramos, portanto a socialização como um processo interminável de interação entre os indivíduos e as instituições, passível de transformações, muito mais significativo, no entanto, em alguns ciclos da experiência humana bem como para determinados grupos sociais para os quais a sua aceitação perante a coletividade possa parecer indispensável às relações que se estabelecem socialmente.

Considerando que a teoria do construcionismo social tenha sido extensamente premiada durante toda a discussão temática a respeito do conceito de gênero, especialmente quando tratamos da indissociabilidade entre gênero e sexualidade na instância identitária, optamos por aprofundar neste item a discussão sobre a importância da socialização de gênero como fundamento para o nosso trabalho.

The term socialization refers how individuals learn about the roles and expectations that they play within a society and the way in which they develop a sense of self. (...)

Sex role socialization, also termed gender socialization, involves beliefs about gender roles, the expectations associated with each sex group, and, also, gender identity, an understanding of what it means to be a male or female. Gender socialization is probably one of the most basic aspects of the general socialization process. Research suggests that children learn that the world is gendered at a very young age and, soon after, develop a sense of their own gender identity.

STOCKARD, 2007, p. 79. 
Os trabalhos focados em pesquisas voltadas à investigação dos processos de socialização de crianças, nos primeiros anos de sua vida, tornaram possível identificar que algumas das condutas "genderizadas" surgiam praticamente sem a interferência dos agentes socializadores adultos constituindo-se em uma forma bastante peculiar de reconhecimento das distinções de origem biológica. Esse processo poderia, portanto, ser compreendido como uma forma elementar de dar sentido a uma diferenciação percebida como "natural" ao organizar as informações recebidas do ambiente.

In terms of gender socialization in education, it is important to note that these sex
differences occur long before children enter elementary school and even before they
enter nursery school. Even more important, the focus of cognitive development
theory on children's interpretations and understandings of their environment and the
social world shifts attention away from the focus of much of the popular literature,
such as teachers' actions and the content of school curricula.
In more recent years, scholars have used the notion of 'schemas', or cognitive
frameworks, to help understand the very early appearance of gender differences and
gender-typed behavior. Schemas are cognitive structures that people use to organize
and process information in which they are exposed. Psychologists believe that
people use schemas as an efficient way to organize new knowledge and information;
they help us maintain consistency and predictability in new situations. Gender
schemas are used to organize information on the basis of gender categories.
As children come across information or new situations that pertain to gender, they
tend to use gender schemas as a guide for interpreting this information. This can
help them simplify information and decisions. Research suggests that children can
discriminate males and females and link characteristics such as hair and clothing
styles to these differences by one year of age, indicating that rudimentary gender
schemas have developed by that point. Research also suggests that children use this
gender schema as an 'in-group/out-group' model. (...)

STOCKARD, 2007, p. 81.

Os esquemas cognitivos, cuja função é extremamente relevante na construção do conhecimento do sujeito, afetam profundamente as relações que este estabelece com o meio uma vez que referendam a sua forma de ler e compreender o mundo, contribuindo simultaneamente para criar parâmetros, padrões, regras e normas, tanto no âmbito de seu conhecimento abstrato quanto no que diz respeito a referenciais para a sua conduta e seu comportamento, muitas das vezes de forma praticamente inconsciente.

Estes esquemas subsidiam a construção dos modelos a partir dos quais se interpretam as informações que nos chegam do ambiente, que, ainda que sejam suficientemente estáveis para subsidiar a nossa compreensão dos fatos, não são necessariamente permanentes e imutáveis.

A forma como cada sujeito "monta" seus próprios modelos pressupõe uma interação com o repertório que estiver à sua disposição no espaço em que está inserido, de maneira extremamente ativa, sendo mais ou menos influenciada pelos outros significativos com os quais interage, fator este que se potencializa em determinados momentos da sua existência. 
Há, portanto, inegavelmente, alguns referenciais que estão postos e que servirão de subsídios para a construção dos modelos de interpretação de mundo de cada sujeito. Alguns deles são extremamente influentes e perpassam instâncias que passam praticamente despercebidas.

A conquista da condição de superação desse relativo "automatismo" de padrões estabelecidos pressupõe uma conscientização gradativa quanto à lógica que os sustenta.

Neste sentido é importante que seja crescente a preocupação de teóricas e teóricos da área em identificar as suas redes de influência, em sua maioria veladas e, as formas como possam estar se perpetuando,

(...) aponta a necessidade de quebrar a indiferença (...) em relação às diferenças sexuais entre crianças e adolescentes. Tal comportamento é no mínimo surpreendente (...) já que isto se passa numa sociedade em que tanto a educação informal (...) como a formal (...) apontam sinais transparentes de um alto grau de diferenciação sexual no tratamento dado às crianças. (...)

De fato, é muito provável que uma análise que passe ao largo destas diferenças socialmente construídas não capte a diversidade das relações sociais e portanto oriente de forma distorcida quaisquer ações intervencionistas. Só é possível entender a indiferença e o desinteresse com relação ao fato óbvio de as crianças terem dois sexos diferentes se lembrarmos que a discriminação costuma estar tão calcada em nós, passa a ser tão corriqueira que não nos damos conta dela. Aliás, com relação a este aspecto basta lembrar que até bem pouco tempo havia também uma total indiferença com relação ao papel diferenciado que a mulher ocupa na sociedade. Acontece que uma pessoa não se transforma em mulher ou homem somente na etapa adulta da vida. Ao contrário, (...), esse processo é extremamente longo, tendo início antes mesmo do nascimento. A situação específica em que se desenvolve a meninice em geral, e a pobre em especial, permanece ainda invisível exatamente porque a perspectiva de gênero tem sido deixada de fora das análises sobre a infância.

(grifos nossos)

MADEIRA, 1996a, p.8.

Assim, entendemos, que considerar as condições que afetam, especialmente, a infância, a puberdade e a adolescência será tanto mais relevante em nossos estudos e pesquisas quanto maior a urgência de repensar uma lógica social que tem privilegiado a poucos e cobrado um alto preço de muitos.

Se por um lado, assumir que a trajetória das subjetividades, na construção dos significados que elabora, esteja perpassada de influências das mais diversas implica em admitir que tal constituição seja tanto mais sensível aos modelos conhecidos possíveis de serem adotados quanto o é a sua vulnerabilidade em todas as direções; por outro lado, há que se considerar que esse processo de percepção e interpretação das informações que o sujeito tem à sua volta vai se tornando gradativamente mais complexo à medida que avança cronológica e intelectualmente fazendo com que novos fatores - sejam de ordem interna e/ou de ordem externa - passem a ser considerados exigindo-lhe uma organização muito mais elaborada das referências que são percebidas a partir do meio. 
Este será, também, um dos momentos propícios para empreender rupturas...

Há determinadas circunstâncias que aprofundam ainda mais a necessidade de buscar coordenar elementos, muitas vezes contraditórios e controversos, neste universo específico e que demandam que o sujeito busque uma coerência lógica entre as mais diversas variáveis que constituem as relações de gênero.

Conseqüentemente, as relações de gênero, situadas sempre em contextos sociais
específicos demarcam espaços, delimitam possibilidades e configuram matrizes ou
modelos de interação entre as pessoas, implicando pressões sobre aquelas que as
transgridem ou subvertem. E inegável, por exemplo, a diferença entre as
possibilidades de que dispõem os adolescentes de classe operária em relação a
outros dos estratos médio ou alto de uma mesma sociedade. Com tão limitadas
perspectivas de vida e educação, não surpreende que as desigualdades de gênero
possam ter um peso maior nas camadas de baixa renda. TRAVERSO-YÉPEZ \& PINHEIRO, 2005, p. 148 e 149.

Gênero na instância da socialização é, portanto uma dimensão que estabelece seus próprios estatutos de validação gerando potencialmente desvios e distorções em função dos recursos de que disponha cada individualidade para "construir" seus próprios modelos e que podem acabar por instituir uma lógica própria para o feminino e para o masculino muito frequentemente hierarquizada.

$\mathrm{O}$ conceito de gênero consolidado na expressão relações de gênero representa a aceitação de que a masculinidade e a feminilidade transcendem a questão da anatomia sexual, remetendo a redes de significação que envolvem diversas dimensões da vida das pessoas. Comporta a permanente interdependência entre o biológico e o psicossocial em cada cultura específica. Como destacado por Vaitsman, 'Homens e mulheres distinguem-se enquanto sexos, pois dotados de corpos físicos diferentes, e enquanto gêneros, uma vez que incorporam normas e valores sócio-culturais que dizem, como um homem ou uma mulher devem se comportar".

É a esse processo de incorporação que se aplica a expressão socialização de gênero. Considerando o processo de socialização como permanente e sempre inconcluso, diríamos que as categorias de gênero são permanentemente reconstruídas pelas pessoas em suas interações e com elas os valores, papéis, atribuições e normas de interação entre os sexos.

Nessa perspectiva, as relações de gênero permeiam, dinamicamente, todo o tecido social, manifestando-se de formas específicas nos diferentes grupos sociais, ainda que mantendo, geralmente, a hierarquização como marca. Nas palavras de Lavinas, '...o sexo social - portanto, o gênero - é uma das relações estruturantes que situa o sujeito no mundo e determina ao longo de sua vida, oportunidades, escolhas, trajetórias, vivências, lugares, interesses'. É nos espaços de convivência cotidiana, mais particularmente a família e a vizinhança, 'que meninos e meninas aprendem e internalizam seu gênero, de acordo com aquilo que a sociedade local exige que sejam...'(...) Assim, a hierarquização de gênero perpassa tempos e rotinas, jogos e brincadeiras, perspectivas e projetos de futuro, reproduzindo os papéis de gênero vigentes no grupo social ao qual pertencem os sujeitos implicados.

TRAVERSO-YÉPEZ \& PINHEIRO, 2005, p. 149.

Neste contexto é que buscamos compreender como se estabelecem os modelos de legitimação para os padrões de gênero, intencionalmente polarizados, no intuito de identificar a sua relevância no grupo dos adolescentes investigado. 
Retomando as considerações do capítulo sobre a socialização de gênero na enciclopédia "Gender and Education" que apontavam para o fato de que a grande maioria das pesquisas atuais que consideram a socialização para a análise das relações de gênero pouco tem atentado para a relevância que assumem os pares na apropriação de preceitos e códigos adotados pelos grupos, e que segundo Stockard são consideravelmente importantes durante a infância e a adolescência, focamos nossa atenção especialmente neste aspecto. A legitimação coletiva dos padrões por eles admitidos interessou-nos particularmente no que diz respeito à forma como os jovens reconhecem seus pares em relação àquilo que foi entendido por feminino e/ou masculino.

(...) o feminino e o masculino são construídos, interpretados e internalizados, portanto personalizados, dependendo das características específicas da sociedade em que homens e mulheres vivem, do ciclo de suas vidas e de suas vivências subjetivas como homens e mulheres que pertencem a uma raça, etnia e classe social determinadas. (...)

TRAVERSO-YÉPEZ \& PINHEIRO, 2005, p.148.

Diante disso, há, portanto, que se considerar que, em toda e qualquer interação humana, existem forças que são exercidas pelos mais diferentes agentes de socialização, desempenhando maior ou menor pressão sobre os sujeitos de acordo com as alternativas de que dispõem, contribuindo ou ameaçando suas possibilidades de superação e transformação.

Como afirmamos anteriormente, estes "modelos" não assumem o caráter de definitivos, mas são centrais para a inserção em um mundo extremamente sexuado, especialmente no momento em que cada individualidade faz suas primeiras escolhas em relação a um(a) parceiro(a) com quem deseja compartilhar descobertas, paixões, prazeres...

Influenciarão, profundamente, as representações anteriormente instituídas, especialmente aquelas constituídas em sua primeira instância de socialização, a família, criando as condições necessárias para uma completa transformação nos pressupostos dos modelos estabelecidos, abrindo espaço para outras tantas "revoluções".

A adolescência pode ser entendida não mais como uma forma evolucionista, linear e teleológica de subjetividade, mas como uma fase de experiências marcadas por corpos e gêneros, como um conjunto de múltiplas referências situadas socioculturalmente.

Tal perspectiva teórica propicia maior sensibilidade e abertura do/a pesquisador/a para com as distintas manifestações juvenis e suas formas de contestação das normas reguladoras vigentes nas sociedades que vivem, sem cair no risco de caracterizar suas ações práticas como progressivas ou regressivas, como irracionais ou de caráter apenas consumista. As distintas concepções de juventude e de viver a juventude serão compreendidas quando analisadas sob a perspectiva de gênero e quando realizadas com base na realidade empírica, que implica todo um trabalho de reconstrução e interpretação das ações concretas dos jovens-adolescentes nos contextos sociais em que estão inseridos. 
Inegavelmente cada grupo, em função da conjunção das variáveis sexo, faixa etária, etnia e classe social terá seus próprios desafios a enfrentar para superar modelos obsoletos de interação social, notadamente hierarquizados, e que, historicamente, têm privilegiado o ideal grego de supremacia do homem, branco e livre ainda que, muitas vezes, de forma velada ou inconsciente.

Se por um lado, tais estatutos, muitas das vezes legitimados por intermédio de esquemas cognitivos de interpretação do mundo, contribuem para a naturalização do "modelo cultural ocidental" da desigualdade pautado na polaridade, as contradições traduzidas por tais binômios, quase que exclusivamente hierarquizados, favorecerão, por outro lado, uma melhor identificação dos seus extremos.

Certamente, reproduzem-se, também, as contradições e dissonâncias existentes, abrindo-se margem para possíveis rupturas ou subversões... Parte-se, portanto, de uma visão sistêmica dos processos de socialização, considerando não apenas os diferentes espaços e trocas interpessoais onde tais processos acontecem, mas também a influência que o indivíduo (seja criança, adolescente ou adulto) exerce sobre o grupo social.

TRAVERSO-YÉPEZ e PINHEIRO, 2005, p. 149.

A socialização de gênero foi por nós assumida, portanto, como uma das possibilidades de investigar a complexidade das relações de gênero que se constituem por intermédio das interações que o sujeito estabelece nas mais diversas instâncias, conjugando o que há de social, interpessoal e intrapessoal, para subsidiar a sua construção de padrões e referenciais de entendimento do mundo.

Tais modelos são entendidos por nós como esquemas cognitivos aos quais o sujeito recorre para dar sentido às suas experiências, tanto ao conhecido quanto ao novo, ao inesperado, como uma espécie de referencial, um repertório de representações que lhe permitirão perceber-se inserido no mundo.

A questão do gênero, no recorte de nossa investigação, apresenta-se também, como caminho para investigar uma lógica de interpretação de papéis a partir da qual se estabelecem redes de influência na constituição das singularidades. Assim adotamos, para a análise dos dados, a perspectiva de um levantamento de crenças e valores, subjacentes às relações de gênero, que contribuem para as "prescrições" feitas pelos jovens, quando da noção de pertencimento do indivíduo a determinado grupo.

Ainda que estejamos convictos da possibilidade das escolhas e performances de cada sujeito, entendemos que tais escolhas e performances, sejam permeadas, muitas das vezes, pelas expectativas dos outros significativos que, de algum modo, referendam a conduta do sujeito, fator tanto mais significativo quanto maior a distância da conquista da autonomia moral. 
Este fenômeno constitui-se especialmente relevante, a nosso ver, na faixa etária à qual nos dedicamos, indispensável para um possível distanciamento que permita assumir, questionar ou romper com os comportamentos "recomendados", de maneira minimamente consciente.

Neste sentido qualquer tipo de vulnerabilidade, seja ela social, geracional, emocional, ou afetiva será assumida como uma séria ameaça à conquista plena de uma possível autonomia moral.

A socialização de gênero, de forma sistêmica, perpassa as singularidades como uma rede de influências sobre a qual se estabelece o entendimento de diversas relações, desde as mais elementares até as mais complexas, criando referenciais a partir dos quais o sujeito possa se situar no mundo, permitindo-lhe perceber-se legítimo detentor de escolhas e opções na instância da subjetividade e cujo efeito pode vir a alçar o grupal, o coletivo, o social, o planetário...

\section{3 MODELOS ORGANIZADORES DE PENSAMENTO}

Para entender a realidade, as pessoas observam os fatos e os encaixam em "esquemas", como números numa calculadora. No cérebro, a realidade corresponde aos números, e a calculadora são os chamados modelos mentais, esquemas criados pelas pessoas para compreender o que acontece no mundo. Estão presentes em todo o conhecimento que se adquire ao longo da vida - da infância, com as primeiras influências familiares, à fase adulta, com experiências sociais e profissionais.

Época, ed. 393, p. $89^{23}$

A tendência à simplificação, na atualidade, é tão significativa que frequentemente nos deparamos com explicações excessivamente superficiais que pretendem aplicar uma suposta regularidade a uma infinidade de fenômenos.

O paradigma da simplificação pretende "encaixar" a realidade que percebemos em modelos precisos e previsíveis, preferencialmente matemáticos...

Morin (1997), o teórico da complexidade, defende a idéia de que tenhamos adquirido uma nova forma de "cegueira", semelhante à medieval, desta feita em função do uso desmedido da razão, para dar conta de todas as circunstâncias.

Segundo o autor, o maior problema do conhecimento atual seria o modo como se busca organizar os saberes em princípios ideais, traduzidos ora em teorias, ora em ideologias. A ignorância contemporânea seria fruto do próprio desenvolvimento da ciência de uma maneira excessivamente compartimentada, perdendo-se em parte a visão do todo.

\footnotetext{
${ }^{23}$ O desafio de mudar. Rio de Janeiro: Editora Globo, Rev. Época, no. 393, 28 novembro 2005, p. 88-93.
} 
Entende o pensador que a organização "mutiladora" do conhecimento gera a incapacidade de apreender a complexidade do real.

Partindo da lógica cartesiana, de postular como verdades absolutas idéias simples e claras, perderam-se os meios que pudessem vir a dar conta de conceber a complexidade dos fenômenos. Ainda que reconheça os benefícios alcançados por intermédio dos princípios centrais do modelo cartesiano de ciência, afirma Morin que, sob sua regência, ficou instituído o império da simplificação, que reiteradamente recorre às disjunções, reduções e abstrações, para dar conta de explicar o mundo.

O modelo científico tradicional, simplificador, reducionista, buscou generalizações tão abrangentes que chegaram a transformar as possíveis diferenças - fruto em nosso caso da diversidade - em exceções à regra. Tem-se que o pressuposto central do mundo das idéias ocidental fundamentou-se no uso exclusivo da razão, pois o atributo de pensar, racionalmente, é visto como capaz de dar conta de todas as instâncias do psiquismo humano.

Araújo (1999) a partir de considerações sobre outras instâncias de nossa maneira singular de pensar e elaborar significados apresenta-nos uma alternativa a tal visão.

\begin{abstract}
Em busca de uma melhor explicação para a complexidade da natureza humana e das relações intra- e interpsíquicas que caracterizam as relações de cada ser humano com seu mundo interno e o mundo externo, nos últimos anos venho desenvolvendo um modelo explicativo complexo e sistêmico em que diferentes dimensões se articulam na constituição do psiquismo. Tal modelo pressupõe, além de dimensões da consciência e do inconsciente, outras dimensões, como a cognitiva, a sociocultural, a biológica e a afetiva. Todas elas estão inter-relacionadas entre si de maneira sistêmica de tal forma que sua separação só é possível para efeitos de estudo e para facilitar sua compreensão.

$\mathrm{Na}$ realidade da vida cotidiana de cada ser humano essas dimensões estão de tal forma indissociadas que não é possível diferenciá-las. Assim, do ponto de vista intrapsíquico, nossos pensamentos, sentimentos e ações são organizados pela articulação dos elementos cognitivos, afetivos, biológicos e socioculturais, mediados simbolicamente ou não pela consciência e pelo inconsciente.
\end{abstract}

ARAÚJO, 1999, p. 154/155

A interação das diferentes dimensões constitutivas do psiquismo humano entra em ação para interpretar e significar os fatos com os quais o sujeito se defronta em seu dia a dia e traz a necessidade de buscar outras possibilidades que pretendam ampliar a questão.

As considerações iniciais do presente item têm por objetivo apontar que nenhuma das maneiras encontradas de conceber o pensamento e o raciocínio traz em si mesma a totalidade das possibilidades inerentes à complexidade da mente humana. 


\section{3. A - Origem das idéias de estruturas, esquemas e modelos mentais}

A psicologia genética ${ }^{24}$ esteve, tradicionalmente, pautada em compreender a construção de conhecimento do sujeito a partir de pressupostos do raciocínio lógico-formal.

Neste sentido, uma grande variedade de pesquisas e investigações tiveram por propósito tentar identificar como se parte de estágios de conhecimento menos elaborados para etapas mais complexas e encadeadas.

Postulou-se que buscando dar sentido aos fenômenos à sua volta o sujeito idealizado do conhecimento, a partir da infância, iria desenvolvendo estruturas, ou formas de pensamento, que lhe permitiriam gradativamente dar sentido aos fatos para compreender o mundo.

De uma etapa extremamente sensorial fundamentada apenas nas sensações e nos sentidos até atingir estágios mais articulados de abstração, o conhecimento, pouco a pouco, iria se constituindo e criando determinados padrões que serviriam de fundamento para novas aprendizagens.

Piaget, um dos precursores desta área de estudos, centrou sua teoria nas estruturas do conhecimento focando seu interesse no raciocínio lógico matemático. Interessava-lhe, especialmente, entender como as crianças construíam padrões que lhes permitissem atingir etapas futuras de conhecimento mais elaborado. Tais padrões seriam estruturas de conhecimento geral, normativo, elaboradas por um sujeito ideal, o chamado sujeito "epistêmico" que conhece.

O estudioso pretendia identificar as estruturas mentais comuns ao desenvolvimento, independentemente do tempo e da cultura, cuja função cognitiva seria o de estabelecer as regras gerais para a resolução dos problemas de uma mesma ordem. Essas estruturas, de concepção próxima às estruturas biológicas orgânicas, uma vez desenvolvidas seriam permanentes.

Os conceitos de assimilação e acomodação ${ }^{25}$ no processo “interacionista" de conhecimento foram revolucionários demonstrando que nenhum conhecimento está latente nem no próprio sujeito nem no objeto, decorrendo, a bem da verdade, da interação entre ambos. A relação estabelecida do sujeito para com os fenômenos apreensíveis do objeto

\footnotetext{
${ }^{24}$ A psicologia genética propõe-se à investigação da gênese da construção do conhecimento.

${ }^{25}$ Assumimos a assimilação como sendo a habilidade do sujeito cognoscente em identificar, no fenômeno a ser apreendido, as suas possibilidades de exploração permitindo-lhe "absorver" as características que lhe permitirão identificá-lo, mapeando-o. A acomodação, por sua vez, é por nós entendida como sendo a "incorporação" deste fenômeno ao repertório do sujeito passando a fazer parte das estruturas de conhecimento constituídas permitindo que o objeto venha a ser reconhecido futuramente. Lembramos que muitos dos termos adotados por estas concepções remetem-se à terminologia específica do campo da Biologia em função das influências do próprio Piaget. Vale salientar ainda, que assimilação e acomodação são conceitos amplamente abordados na extensa obra de Jean Piaget sobre a epistemologia genética.
} 
permitiria a formação de estruturas mentais que garantiriam a sua aplicabilidade em outras circunstâncias semelhantes.

A teoria "piagetiana" é considerada uma teoria estruturalista, porém, o próprio Piaget chegou a admitir que tal teoria não contempla todas as formas de entendimento e apreensão dos fenômenos. Percebeu que um sujeito capaz de aplicar uma estrutura mental específica em determinado contexto pode não ser capaz de fazê-lo em outro. $O$ princípio da não generalização, atribuído inicialmente à exceção, pareceu-lhe poder ser muito mais freqüente do que havia suposto.

Vale salientar que, em suas investigações, não foram prioridade outras instâncias do psiquismo humano, para além das estruturas intelectuais, enquanto atributo racional, ainda que não as tivesse, a princípio, negado.

Estava posto, no entanto, que as estruturas de construção do conhecimento eram uma das estratégias mentais para o entendimento e explicação dos fenômenos.

Em linha de investigação similar àquela empreendida clinicamente por Piaget, Bärbel Inhelder (1996) dedicou-se a contemplar as condutas cognitivas, singulares, dos sujeitos quando de seus conflitos de aprendizagem.

Conscientes da fecundidade do ponto de vista construtivista no estudo da gênese das categorias gerais do conhecimento, procuramos perseguir os mecanismos funcionais subjacentes aos procedimentos da criança em vias de resolver problemas específicos. Esperamos, assim, contribuir para uma concepção construtivista da psicologia, complementar àquela da Epistemologia Genética.

INHELDER, 1996, p. XI.

Inhelder afirma categoricamente que a sua proposta para as estratégias utilizadas pelo sujeito na resolução de conflitos não contradiz os princípios estruturais piagetianos, mas que permite avançar em relação a eles.

(...) a psicologia genética havia descrito notavelmente a epistemologia espontânea do sujeito cognoscente e as estruturas organizadoras de seus conhecimentos, mas não realizara uma verdadeira análise do "saber-fazer" (savoir faire) de cada sujeito em sua individualidade. Não estaríamos certos em supor que a psicologia genética vinha definindo assim uma arquitetura geral do conhecimento, em suma, estruturas de um sujeito epistêmico, mas que permanecia inexplorado um vasto domínio de condutas que faziam intervir toda uma variedade de esquemas cognitivos mais heurísticos do que os das estruturas gerais do conhecimento?

INHELDER \& CAPRONA, 1996, p. 8.

Complementando a noção da macrogênese "piagetiana" do conhecimento - das organizações estruturais universais, ou grandes noções constitutivas de explicação para os fenômenos - Inhelder traz a idéia da microgênese - dos procedimentos individualizados pragmática e empiricamente elaborados diante de um objetivo específico - igualmente relevante para o entendimento da complexidade do raciocínio humano. 
A atenção de Inhelder voltou-se à apreensão dos aspectos funcionais cognitivos e focando-se na identificação das condutas intencionais do sujeito frente a seu objeto de conhecimento e, neste sentido, para além daquilo que é apreensível de modo genérico, por intermédio das estruturas anteriormente formadas (ou não), os procedimentos individuais visando compreender um determinado fenômeno seriam uma maneira de individualização do conhecimento.

Introduziu-se, então, a questão dos procedimentos como uma maneira singular de apropriação do conhecimento universal.

\begin{abstract}
A identificação dos processos seqüenciais (isto é, comportando sucessões e desenvolvimentos não contínuos) assume, em conseqüência, extrema importância, e coloca todo o problema dos respectivos recortes (découpages), próprios do sujeito e do observador. Cremos que só sucessivamente podemos identificar os recortes que o sujeito faz para desvelar seus procedimentos ou encadeamentos de ações (...)
\end{abstract}

INHELDER \& CAPRONA, 1996, p. 12.

Segundo a autora, o sujeito psicológico entra em ação, na apreensão do objeto de conhecimento, recorrendo à elaboração de processos peculiares de entendimento, visando alcançar um objetivo, específico, acontecem aí sucessões possíveis, de tentativas e erros, passíveis das alterações necessárias, avaliando e reavaliando constantemente a pertinência do conhecimento aplicado, que permitirão alcançar a resolução de uma tarefa específica. A seqüência das estratégias adotadas, no cumprimento de um intento evidencia os procedimentos práticos do sujeito cuja importância, na organização mental do processo cognitivo, se equivale à construção das estruturas universais, segundo Inhelder.

Os esquemas, ou procedimentos de aprendizagem, não têm, necessariamente, uma relação direta com as estruturas anteriormente desenvolvidas. Cada seqüência de procedimentos poderá, ou não, gerar novos conhecimentos, novas estruturas e poderá refletir, ou não, uma estrutura já desenvolvida.

Os esquemas são temporais e têm por função realizar adequadamente uma determinada tarefa. São condutas do sujeito que poderão ser validadas como um percurso a ser retomado em outras circunstâncias ou uma trajetória a ser rejeitada. Um meio para atingir um fim específico. Poderão se tornar permanentes, integrando-se a outros esquemas mais abrangentes ou serão substituídos por outros mais eficientes.

Há, portanto, um processo, anterior à constituição efetiva de uma possível estrutura, que revela parte do processamento psíquico do sujeito e que assume extrema relevância no modo particular de apreender os fenômenos.

O sujeito psicológico nos interessa enquanto sujeito cognoscente, mas com suas intenções e valores. Somos levados a atribuir um papel importante às dimensões teleonômicas e axiológicas da atividade cognitiva, isto é, às finalidades e avaliações 
produzidas pelo próprio sujeito. Trata-se, pois, de visualizar o sujeito com os fins a que se propõe e os valores que atribui.

INHELDER \& CAPRONA, 1996, p. 9.

Às estruturas espontâneas integram-se os esquemas intencionais, conforme nos propõe a autora.

Outro conceito relevante para a psicologia cognitivista, também fundamental para o entendimento dos processos cognitivos, é a dos modelos mentais, conforme Moreno Marimón 2002.

\begin{abstract}
Os trabalhos de Johnson-Laird baseiam-se fundamentalmente no estudo dos modelos mentais que os sujeitos elaboram a partir de enunciados verbais. Os resultados que obtém levam-no a expor o problema da insuficiência da lógica formal para explicar como se extrai uma conclusão particular de algumas premissas em uma situação diferente da que se dá nos clássicos silogismos, já que, se os princípios lógicos podem determinar se uma conclusão é ou não válida, são incapazes de determinar que conclusão se extrairá de uma situação concreta que admite múltiplas conclusões, pois, para poder derivar uma conclusão específica a partir das premissas, é necessário um princípio extralógico que as guie (Johnson-Laird, 1981). Nesses trabalhos assinala o fato de que a teoria de Piaget - entre outras teorias do raciocínio - não tenha considerado a incapacidade da lógica para proporcionar por si só, uma formulação de uma teoria da inferência.
\end{abstract}

MORENO MARIMÓN, 2002, p. 36.

Concepção elaborada por Johnson-Laird (1983; 1992), a partir de uma idéia anteriormente sugerida por outros autores (Wittgenstein, 1922; Craik, 1943; Gentner e Stevens, 1983; Rogers, 1992), um modelo mental se constitui em uma forma peculiar de organizar os dados do mundo real - ou objetos do conhecimento - decorrente da percepção própria do sujeito.

Para tal linha de estudos, ao tentar apreender seu objeto de conhecimento o sujeito cria correspondências entre o objeto e a representação mental que dele faz, elemento a elemento, elaborando modelos da realidade.

Essa característica não pressupõe, no entanto que todo elemento presente no objeto "real" esteja necessariamente representado no modelo mental.

Um modelo mental é composto de elementos ("tokens") e relações que representam
um estado de coisas específico, estruturados de uma maneira adequada ao processo
sobre o qual deverão operar. Ou seja, cada modelo já é construído de uma maneira
coerente com o uso previsto (STAF 11,1996). MOREIRA, 1997.

Decorre desta peculariedade o fato de que alguns modelos possam ser aplicáveis única e exclusivamente a uma determinada finalidade, com uma utilidade específica, não sendo aplicáveis a nenhuma outra situação.

Há, no entanto um eixo central de coerência interna que rege um modelo garantindo sua aplicabilidade. 
O modelo mental de avião, por exemplo, possui distintas versões conforme os diferentes usos que se possa fazer de um avião: reconhecê-lo, construí-lo, pilotá-lo, embarcar nele, falar sobre ele. O modelo varia também segundo outras dimensões: a competência aeronáutica do sujeito, sua idade, sua cultura, etc. Representar um avião em vôo ou um avião aberto para mostrar os lugares aos passageiros também corresponde a diferentes versões do modelo mental de avião. Cada versão, no entanto, deve incluir o núcleo central que identifica o modelo com sendo de avião. Deve também incluir proposições e procedimentos de manipulação diversificados, visto que, conforme o uso, são outros os aspectos do modelo que são acionados. É possível que dois exemplares do mesmo modelo pouco ou nada tenham em comum se forem construídos com finalidades totalmente diferentes (ibid.). (STAF 11, 1996).

MOREIRA, 1997.

Modelos mentais são entendidos, assim, como uma estratégia de elaboração de significados com uma função específica.

Para Johnson-Laird, ao invés de uma lógica mental, as pessoas usam modelos mentais para raciocinar. Modelos mentais, (...), são como blocos de construção cognitivos que podem ser combinados e recombinados conforme necessário. $\mathrm{O}$ aspecto essencial do raciocínio através de modelos não está só na construção de modelos adequados para captar distintos estados de coisas, mas também na habilidade em testar quaisquer conclusões a que se chegue usando tais modelos. A lógica, se é que aparece em algum lugar não está na construção de modelos e sim na testagem das conclusões pois esta implica que o sujeito saiba apreciar a importância lógica de falsear uma conclusão, e não apenas buscar evidência positiva que a apóie. (Hampson e Morris, 1996, p. 243 apud Moreira, 1997)

MOREIRA, 1997.

Compreender, dentro de tais princípios, seria elaborar modelos mentais do mundo e raciocinar, a capacidade de manipulação e combinação destes mesmos modelos.

Outra consideração relevante que poderia ser acrescentada à discussão seria uma possível distinção na origem da construção dos modelos mentais (Gentner e Clement, 1988; Holoyak, 1984, 1985; Gentner e Stevens, 1983; Norman, 1983; Williams, Hollan e Stevens, 1983; McCloskey, 1983; Lakoff e Jonhson, 1980, 1987; Champagne, Kopfer e Anderson, 1980; Clement, 1982; Minstrell, 1982; Trowbige e MsDermott, 1980; Viennot, 1979; entre outros) em razão das necessidades a que atende.

Ainda que não haja unanimidade na maneira de classificar as distintas possibilidades de elaboração dos modelos mentais, assumimos a perspectiva de Moreno Marimón (2002) que adota uma diferença entre modelos mentais causais e modelos mentais analógicos.

Conforme a distinção apresentada, entende-se por modelo causal, um modelo de função conceitual que se aplica quando da apreensão de sistemas físicos, concretos, que tenham leis que os ordene. Os modelos causais vão se construindo a partir de hipóteses sucessivas que possam vir a explicar os fenômenos apreendidos da "realidade". Esta categoria de modelos apresenta-se como similar a uma sistematização de dados do "mundo físico" para compreender os fatos. 
Modelos analógicos, por sua vez, poderiam ser entendidos como uma maneira de buscar referenciais na própria experiência para compreender os novos desafios. Ainda, segundo Moreno Marimón (2002), "o uso de analogias para explicar e até mesmo descrever os fenômenos, situações ou objetos observados está presente tanto na vida cotidiana como no pensamento científico". Dito em outras palavras, é possível diante do desconhecido, encontrar padrões e/ou relações que possam estabelecer parâmetros de associação com alguma experiência prévia. Dentro desta concepção, a construção de modelos, recorrendo a representações analógicas, seria uma das estratégias cognitivas à qual recorre o sujeito, quando existe a possibilidade de aplicação de alguma espécie de conhecimento anterior.

Quando o sujeito deve interpretar um fenômeno da realidade emprega para isso, conhecimentos anteriores que possui. Se estes forem adequados, poderá usá-los e compô-los, se necessário, para obter uma boa representação do fenômeno que lhe permita elaborar um modelo pertinente. Mas, se seus conhecimentos não forem adequados, recorrerá a modelos analógicos extraídos de seus conhecimentos anteriores, armazenados em sua memória a longo prazo.

MORENO MARIMÓN, 2002, p. 50.

Inúmeros estudos (Young, 1983; Waern, 1987; Rutherford e Wilson, 1992; Rogers, 1992; Sasse, 1992; O’Malley e Draper, 1992; Rogers e Rutherford, 1992; Johnson-Laird, 1993) acabaram por demonstrar que os modelos mentais se constituem em um dos recursos que sustentam a construção do conhecimento, dentre as mais diversas estratégias mentais às quais o sujeito recorre para resolver os impasses diante das situações que demandam sua compreensão, para muito além das estruturas do raciocínio lógico matemático.

A partir desta estratégia de apreensão e compreensão de mundo, um dos aspectos que assume maior relevância é o papel das representações na elaboração de um modelo.

(...) Esses modelos mentais constituem uma forma de representação dos conhecimentos por meio dos quais o ser humano constrói a realidade e isso the permite, quando realiza um processo de simulação mental, conceber alternativas e verificar hipóteses. O papel da representação, dentro dessa teoria, é fundamental para explicar tanto a elaboração de modelos como sua manipulação pelo pensamento.

MORENO MARIMÓN, 2002, p. 37.

Se, anteriormente, as estruturas previstas por Piaget concentravam-se, predominantemente, na forma e nas estruturas, os esquemas de Inhelder, priorizando os procedimentos adotados e os modelos mentais de Johnson-Laird, focando as relações que o sujeito estabelece a partir do objeto, revelaram a importância dos aspectos funcionais e das representações do sujeito, respectivamente, na construção do conhecimento.

Não nos interessam aqui as possíveis críticas posteriores feitas a esta ou aquela forma de reconhecer as estratégias mentais de construção de conhecimento, mas validar o interesse que nos despertaram tais considerações, enquanto subsídios para compreender os pressupostos 
a partir dos quais se constituiu a possibilidade de uma análise, adotando os modelos organizadores de pensamento.

Considerar os aspectos operatórios da teoria de Piaget, os aspectos procedimentais de Inhelder e os aspectos representacionais do pensamento de Johnson-Laird, entre tantos outros possíveis e não contemplados em nossa reflexão nos permite reafirmar a complexidade do pensamento humano que continua a desafiar pesquisadores e estudiosos do tema.

Amparados por Arantes (2003), Lemos de Souza \& Vasconcelos (2003), Lemos de Souza (2008), entre outros, assumimos que os pressupostos apontados acima tenham servido como "inspiração" para a origem dos Modelos Organizadores de Pensamento, metodologia de análise de dados à qual recorremos para subsidiar a apreciação de nossa pesquisa de campo.

\section{3. B - A concepção dos modelos organizadores de pensamento}

A origem dos pressupostos dos modelos organizadores do pensamento remete-se especialmente aos estudos piagetianos sobre a gênese do desenvolvimento cognitivo em crianças, considerando outras contribuições que levantaram hipóteses complementares relevantes, conforme visto anteriormente.

A grande contribuição de Piaget, mais que o estudo dos estágios de desenvolvimento cognitivo definidos, segundo Moreno Marimón foi demonstrar "o papel do sujeito como organizador da realidade" e a maneira como descreve "as formas que os sistemas organizadores adquirem, cada um deles gerando um precedente, em uma sucessão genética que lhes concede uma continuidade graças às quais se tornam compreensíveis." (Moreno Marimón, 2002, p. 75)

Há que se considerar, portanto que um dos maiores aportes das propostas piagetianas, além dos tradicionalmente mais reconhecidos, é o papel do próprio sujeito na organização particular que infere a um fenômeno atribuindo-lhe significado; sua compreensão de mundo será uma construção progressiva cuja complexidade crescente decorre da elaboração das etapas anteriores.

Um mesmo sujeito, entretanto, ainda que tenha alcançado as estruturas formais mais elaboradas de seu raciocínio lógico matemático poderá vir a ser confrontado com o imprevisto, com o desconhecido o que lhe demanda predisposição e abertura para o novo. $\mathrm{O}$ sujeito do conhecimento se transforma no contato com o mundo, no entanto as transformações do mundo também devem ser consideradas. Diante da apreensão dos fenômenos do cotidiano aos quais não seja aplicável, de imediato, uma estrutura formal, previamente desenvolvida, a 
mente buscará estratégias para apreender aquilo que possa vir a dar conta de construir uma explicação minimamente plausível para tal acontecimento.

Piaget centrou seus estudos nas estruturas permanentes do raciocínio humano, sem abordar aspectos do conteúdo, ou seja, da "impermanência" das informações e estímulos do próprio meio e nesse sentido, as estruturas possíveis de serem constituídas serão sempre finitas em função das próprias limitações humanas, enquanto os conteúdos são da ordem de um universo infinito de possibilidades.

É esta a questão central que introduz a necessidade de abordar a temática, a partir de uma nova perspectiva.

Se abordamos a atividade cognitiva do sujeito a partir dos "dados" ${ }^{26}$ que ele considera em uma situação concreta, isto é, dos elementos da realidade aos quais confere significado e dos que desconsidera, surge para nós uma nova série de problemas que obrigam a importantes reformulações teóricas. Para dar conta desses problemas, convém recorrer à idéia de "modelo", que, como vimos, foi utilizada com êxito por outros autores e à qual vamos dar uma orientação particular, capaz de contemplar simultaneamente os dados e as relações ou operações que organizam.

MORENO MARIMÓN, 2002, p. 78.

Assim, a perspectiva dos modelos organizadores de pensamento foi concebida como uma "prolongação sobre as origens da representação e a extração das conseqüencias que se seguem". 27

Elaborada pelas professoras Montserrat Moreno e Genoveva Sastre da Universidade de Barcelona, Magali Bovet do Centro Internacional de Epistemologia Genética de Genebra e Aurora Leal da Universidade Autônoma de Barcelona, coloca-se como uma busca por dar conta da complexidade do psiquismo humano, atentando para as dimensões cognitivas, afetivas e sócio-culturais de sua dinâmica.

\begin{abstract}
A complexidade dos modelos organizadores pressupõe relações entre estrutura e conteúdo e é composta pela realidade objetiva e subjetiva do sujeito. Segundo Moreno e col. (1999), os modelos são elaborados na interação do indivíduo com o meio, que atua como regulador da atividade cognitiva. O sujeito - ativo nesse processo - assimila os dados de uma situação concreta e atribui significado e uma função a eles, construindo um modelo para explicar a situação.
\end{abstract}

LEMOS DE SOUZA \& VASCONCELOS, 2003, p. 50.

Segundo a proposição, cada indivíduo institui uma lógica que lhe é própria para nortear os julgamentos que faz da realidade, dessa forma, a abordagem dos modelos organizadores de pensamento pressupõe a importância da singularidade da representação de cada sujeito, diante daquilo que possa lhe parecer significativo, nas situações com as quais se

\footnotetext{
${ }^{26}$ Vale salientar que a terminologia "dados" adotada pelas precursoras desta área de pesquisa posteriormente é substituída por "elementos" por recomendação das próprias autoras, entendendo que o termo "elemento" se aplique mais adequadamente aos fins a que se propõem. Portanto, sugerimos que onde se vê "dados" no presente texto leia-se, a partir desta nota, "elementos".

${ }^{27}$ ARANTES, 2003.
} 
depara em seu cotidiano, sejam elas da ordem do conhecimento formal, de sua vida prática ou relacionadas às suas experiências afetivas, sensoriais, sentimentais, emocionais... A partir desta lógica é que podemos, juntamente com as autoras, afirmar que "o indivíduo constrói modelos da realidade que lhe permitem orientar-se e conhecer grande parte do mundo que o rodeia”. (Moreno Marimón, 2002)

A construção de um modelo é a reconstrução mental de uma situação. Alguns elementos serão abstraídos diretamente do objeto para que seja estabelecida uma correspondência.

Diante de uma determinada situação ou fenômeno, um observador não retém todos e cada um dos elementos que é possível considerar para representar essa situação ou fenômeno, mas somente alguns, aqueles aos quais, por diferentes razões, atribui significado. Estes passam a fazer parte do que denominamos "dados" no conseqüente modelo que o sujeito constrói sobre tais situações. Disso deriva que nem todos os dados* que é possível abstrair de um fato estão presentes no modelo organizador do sujeito, mas somente alguns, aqueles que para ele resultam mais significativos.

(observações nossas) MORENO MARIMÓN, 2002, p. 78/79.

Da afirmação acima podemos, ainda, inferir que os elementos retidos por um sujeito poderão não ser retidos por outro. Em razão dos aspectos funcionais que atendem determinados fins, próprios à construção dos modelos é que o sujeito não abstrai do objeto todos os elementos presentes, mas apenas aqueles que lhe pareçam mais significativos para resolver uma questão específica, assim, um modelo organizador é, portanto, um "sistema organizado econômico". Esta característica permite que haja uma compreensão sintética do mundo, cuja função é "agilizar" a apreensão dos fatos. Disso decorre que, ainda que na origem de um fenômeno haja uma suposta objetividade, a forma de apreendê-lo será sempre parcial, seletiva e até certo ponto subjetiva. Os elementos ignorados não são necessariamente desconhecidos; podem ter sido negligenciados por serem considerados menos relevantes que os demais, no entanto, é possível que os elementos não apreciados sejam fundamentais para o entendimento adequado de algumas situações.

É importante salientar, ainda, que os elementos abstraídos, de acordo com os pressupostos dos modelos organizadores de pensamento, não têm necessariamente correspondência direta com o objeto, uma vez que "dados* procedem das percepções, das ações (tanto físicas como mentais) e do conhecimento em geral que o sujeito possui sobre uma certa situação, assim como das inferências que a partir de tudo isso realiza." (Moreno Marimón, 2002) Em contrapartida, de forma semelhante aos elementos desconsiderados, existem aqueles que são inferidos pelo sujeito como pertinentes, ou subentendidos, ao fenômeno em questão. 
Embora haja muitos dados* da realidade que não aparecem no modelo organizador do sujeito, também figuram nele dados* que não existem na realidade e que são produto de inferências - nem sempre pertinentes - a partir de outros dados* ou da compensação pela ausência de algum dado* considerado necessário pelo sujeito e que este não hesita em acrescentar. Esses dados*, que podem ter ou não correlatos na realidade, tem, no entanto, dentro do modelo, o mesmo status daqueles que se originam de observáveis e têm, para quem os constrói, o mesmo caráter de 'reais' que aqueles.

(observações nossas) MORENO MARIMÓN, 2002, p. 79.

A conjunção das "informações" consideradas pertinentes a uma determinada tarefa é que estabelece os fundamentos de seu modelo correspondente.

Uma vez selecionados, os elementos abstraídos ou inferidos, serão a base sobre a qual se construirá o modelo que representa a situação para o sujeito.

Aos elementos serão aferidos significados de forma a garantir a sua coerência; um modelo só será validado pelo sujeito se este lhe parecer compatível com a situação que percebe. Outros elementos poderão ser acrescentados ou retirados até que pareça haver uma lógica intrínseca ao modelo elaborado. Da mesma forma, poderão ser "resignificados" sempre que surgirem novas demandas.

Imputados significados aos elementos, será possível estabelecer conexões, relações de causa e efeito, justificativas, entre tantas outras possibilidades. Assim, "o significado atribuido a um dado* determina suas implicações, ou seja, as conseqüências que dele derivam, ainda que estas não tenham de ser necessariamente as mesmas para diferentes sujeitos.” (Moreno Marimón, 2002)

Os dados*, seu significado e suas implicações estão religados em um sistema de conjunto constituído exatamente pelo que denominamos modelos organizadores; dentro desse conjunto todos os elementos estão inter-relacionados graças a um jogo de relações cujo nível também é variável segundo os indivíduos.

(observações nossas)

MORENO MARIMÓN, 2002, p. 83.

Um modelo é, portanto, uma estratégia mental funcional que decorre das representações às quais o sujeito recorre para dar sentido a uma situação. De forma consciente ou inconsciente, diante de determinada situação, é uma forma singular de interpretar os fatos.

O conjunto de representações que o sujeito realiza a partir de uma situação determinada, constituído pelos dados* que abstrai e retém como significativos entre todos os possíveis, aqueles que imagina ou infere como necessários, os significados e as implicações que lhes atribui, e as relações que estabelece entre todos eles. Os Modelos Organizadores do Pensamento constituem aquilo que é tido por cada sujeito como "realidade", a partir do qual elabora pautas de conduta, explicações ou teorias.

(observações nossas)

SASTRE et al, apud ARANTES, 2003, p. 118.

Como toda e qualquer forma de "ler" e interpretar o mundo, os modelos adotados em um dado momento podem ser revistos ou substituídos por outros, mais adequados, em função 
das demandas do meio, tanto quanto pelas solicitações ou transformações próprias das singularidades. A atribuição de significados e de valores é passível de alterações e modificações.

Se, por um lado, é compreensível que os sujeitos tenham condições de reconstruir seus próprios modelos, ou as suas formas personalizadas de significar o mundo é de se esperar, por outro lado, que da interação do sujeito com o objeto - preceito indispensável ao construtivismo - possam surgir evoluções e revoluções coletivas, para modelos de representação social.

Os modelos individuais evoluem com o desenvolvimento cognitivo do sujeito, como também o fazem os modelos coletivos, dentre os quais figuram, como um caso particularmente privilegiado, os modelos científicos cuja evolução percorre a ampla paisagem da história do pensamento humano.

MORENO MARIMÓN, 2002, p. 79

De acordo com a afirmativa acima, inegavelmente, os modelos coletivos, especialmente os científicos, evoluem e, parece-nos, de forma equivalente, que outros tantos modelos que nos influenciam coletivamente têm avançado, entre eles as próprias representações sociais às quais recorremos, enquanto referencial para as nossas crenças e os nossos valores.

\title{
II. 3. C - Modelos organizadores do pensamento e psicologia moral
}

\begin{abstract}
A Teoria dos Modelos Organizadores (MORENO MARIMÓN et al., 1999), produzida no esteio dos novos paradigmas, torna-se um referencial relevante na compreensão do funcionamento psíquico do sujeito na resolução de conflitos. Nessa proposta o conceito de modelo organizador é um conjunto de representações elaboradas pelo sujeito e composta por elementos, significados e implicações que organizam formas de interpretação possíveis do cotidiano.
\end{abstract}

LEMOS de SOUZA, 2008, p. 2.

A origem dos pressupostos dos modelos organizadores do pensamento remete-se aos estudos piagetianos, sobre a gênese do desenvolvimento cognitivo em crianças. Paralelamente, durante suas pesquisas, Piaget identificou algumas estratégias utilizadas pelos sujeitos, para a resolução das tarefas, especialmente durantes jogos que lhes eram propostos.

Estudos e pesquisas do campo da psicologia moral, também influenciados de alguma forma pelos estudos de Piaget, têm buscado ao longo do tempo identificar o complexo processo de constituição da moralidade humana.

Tradicionalmente as buscas dos estudiosos se concentraram em definir um princípio regente universal que pudesse permitir, a partir do fato de se ter ou não alcançado a sua plenitude, a classificação da moralidade do sujeito, partindo de etapas previamente definidas, que deveriam ser atingidas até o seu grau máximo, alcançando o "desenvolvimento moral pleno" ou dito de outra forma, uma "perfeição moral" idealizada. 
Nesse sentido, muitos foram os teóricos que fundamentaram as suas pesquisas em princípios gerais de atendimento a certos pressupostos, quase que em sua maioria associados à justiça, tais como as clássicas teorias de Jean Piaget e Lawrence Kohlberg. Posteriormente, Carol Gilligan, introduziu uma forma de contrapor a uma moralidade tipicamente masculina, o princípio do cuidado, como uma lógica que regeria a moralidade feminina ${ }^{28}$, ou a "outra metade do mundo".

Outra importante contribuição advém de Seyla Benhabib que defende ser a moralidade regida por uma possibilidade de incluir a dimensão singular do outro. Essa perspectiva se encontra fundamentada em formas de admitir a existência de um "outro generalizado" ou um "outro concreto" permitindo transcender do primeiro sujeito, meramente jurídico, dos direitos e deveres, para um sujeito real, vivo, que existe, também, no campo da legitimação de suas emoções e sentimentos.

Diante das diversas abordagens teóricas a que tivemos acesso, podemos inferir que diferentes perspectivas de uma mesma situação influenciam de algum modo a forma como julgamos as situações de nosso dia-a-dia, especialmente aquelas que eventualmente impliquem circunstâncias conflituosas. As informações que obtemos dos fatos que o meio nos permite perceber são analisadas pelo nosso "juízo moral" e organizadas de modo a lhes dar sentido a partir de nossos próprios referenciais.

A proposta dos modelos organizadores do pensamento, que nasceu na Espanha a partir dos estudos especialmente de quatro pesquisadoras, Montserrat Moreno Marimón, Genoveva Sastre, Magali Bovet e Aurora Leal, pretende, para muito além de priorizar a busca de estágios (ou estádios) de desenvolvimento moral que estabeleçam previamente as categorias de análise determinando uma "evolução moral ideal" e, portanto, desejável, identificar estratégias utilizadas pelo sujeito para dar conta das circunstâncias de seu cotidiano, construindo os seus julgamentos, sejam eles regidos, ou não, por princípios éticos. Esta metodologia de investigação da moralidade humana tem, de certa forma, um caráter funcional, pois pretende reconhecer o funcionamento mental, os recursos a que recorreu um determinado sujeito e que permitiram a organização dos fatos, de modo a permitir-lhe a sua compreensão. De algum modo tais modelos são uma síntese do resultado a que a mente chegou, em sua trajetória de apreensão e compreensão dos fatos, e o que se busca por intermédio deste recurso metodológico é alcançar evidências do percurso da mente em sua construção psíquica própria procurando organizar o pensamento, relacionando forma e conteúdo, estruturas cognitivas e fatos da realidade.

\footnotetext{
${ }^{28}$ A temática foi aprofundada no presente capítulo, no item II.1. C
} 
Fundamental dentro desta proposta é, então, como dito acima, identificar como o sujeito elabora elementos apresentados em determinadas, ou diante das mais diferentes, situações $^{29}$, e, para além dos atributos racionais e intelectuais, pretende-se, com a mesma, adotar a possibilidade de considerar o impacto de sentimentos, emoções e outros aspectos da afetividade que subsidiam os juízos de valor e julgamentos que o indivíduo apresenta.

$\mathrm{Na}$ apreciação que se torna possível fazer, a partir dessa metodologia, fundamentais são a seleção e abstração dos elementos apresentados, a atribuição de significados feita a partir daqueles de fato identificados, na análise do sujeito, e as relações estabelecidas entre estes dois aspectos. Há que ser considerado aquilo que de fato é observado a partir de uma situação apresentada, de como se deu sentido aos fatores selecionados e que implicações se entende haver de um para com outro.

Torna-se relevante entender que cada sujeito pode ter uma forma distinta de organizar tais elementos e que além de reconhecer as informações de fato apresentadas, poderá, também, vir a inferir outras tantas em função de sua forma própria de organização.

Mas, dentro dos pressupostos dessa teoria, o sujeito abstrai da realidade apenas os fatos para os quais lhe é possível atribuir significado e que, de algum modo, se relacionacem à sua experiência, mediante uma organização mental.

Arantes (2003) acrescenta que essa metodologia pretende reconhecer a natureza funcional das atividades da mente elaboradas ao organizar o próprio pensamento, similar a um mecanismo que "economiza" o esforço mental no processamento das informações. (Arantes, $2003 ; 2007^{30}$ ) e afirma:

Tentando esclarecer tais processos funcionais, no processo de abstração de dados*, o sujeito psicológico, diante de determinada situação, certamente não retém todos os dados* da realidade. Faz uma seleção: são retidos aqueles que, para ele, são significativos, e rechaçados aqueles que não considera significativos ou pertinentes. Os dados excluídos não intervêm no juízo desenvolvido pelo sujeito uma vez que foram por ele desconsiderados. (grifos no original)

(observações nossas) ARANTES, 2003, p. 118.

\footnotetext{
${ }^{29}$ Como recurso de aplicação desta metodologia, é comum a utilização de um instrumento narrativo que retrate um conflito entre dois ou mais personagens, onde o sujeito investigado é convidado a se posicionar avaliando a situação conflituosa narrada. A partir desse relato o entrevistado é solicitado a se posicionar diante das informações que lhe foram passadas. As questões que lhe são feitas estão associadas àquilo que se pretende identificar de um conflito de ordem moral, podendo ir desde questões deontológicas, da instância do dever a ser cumprido, até a identificação da influência de pilares da construção da moralidade humana especialmente a justiça, a felicidade e a solidariedade, na constituição de julgamentos do sujeito diante de uma situação apresentada.

${ }^{30}$ Arantes 2007: Observações feitas em sala durante as aulas para a disciplina "Psicologia da Educação I" oferecida aos alunos do curso de Licenciatura em Pedagogia pela Faculdade de Educação da Universidade de São Paulo no segundo semestre letivo de 2007.
} 
A própria Arantes, em sala de aula afirmou: "não nos é possivel reter tudo de tudo... Nós somos de fato seletivos e isso tem a ver com o funcionamento e não com a estrutura. Eu abstraio um "elemento" e ao fazê-lo acabo por atribuir-lhe um significado! Nos modelos organizadores de pensamento alguns elementos são inseridos e eles são tão importantes quanto aqueles que são abstraídos."

A realidade é "traduzida" pelo sujeito de acordo com filtros constituídos a partir de sua experiência. Estruturas, esquemas e modelos se inter-relacionam para tentar "absorver" os conteúdos apresentados. O psiquismo aciona uma espécie de "transformador" em que os estímulos externos ativarão o manancial dos recursos internos para dar conta de explicar a realidade.

Nesse sentido é conferida grande importância à experiência singular e ao conhecimento formal e informal prévios do sujeito, visto que os mesmos influenciarão a seleção dos elementos que serão abstraídos, o significado que lhes será atribuído, e aqueles que serão inferidos, contribuindo para a percepção geral do fenômeno.

Toda percepção pressupõe uma interpretação; a interpretação é uma concepção fundamental na teoria dos modelos organizadores de pensamento.

A partir desta "construção" pessoal abrem-se possibilidades para fantasias, desejos... Estas organizações têm a "função" de dar lógica ao pensamento de cada um... Para dar um mínimo de coerência interna é preciso inferir certos elementos. Essas atribuições de significados estão profundamente relacionadas com os nossos valores. Os modelos têm também uma dimensão cultural. Se este é um modelo teórico que permite identificar a singularidade, permite também identificar a dimensão cultural... Citando Einstein: "Eu só posso ver aquilo que o meu modelo teórico me permite ver".

ARANTES, 2007

Ao reconhecer a importância daquilo que possa ser inferido pelo sujeito, estudos ligados à Teoria dos Modelos, abrem espaço para se considerar outros recursos do psiquismo humano, tais como os desejos, os sentimentos, os afetos, as representações sociais e os valores do indivíduo. Evidencia-se, pois, a hipótese de Arantes (2002) de que os afetos têm também um papel organizador para o pensamento.

E o reconhecimento da relevância do desejo nesse mecanismo é fundamental para se compreender as representações que são feitas a partir das informações recebidas.

Uma das grandes conquistas da teoria dos modelos organizadores do pensamento é a possibilidade de contemplar a diversidade do raciocínio humano considerando a singularidade com que cada sujeito elabora um modelo único de organização mental, e mais, ao mesmo tempo em que se reconhece o que é único - a singularidade - existe a possibilidade de identificar o que há de comum - representações sociais coletivas - entre os diferentes sujeitos.

Há uma particularidade no todo, e uma totalidade no singular. 
Outra possibilidade que se abre diz respeito à idéia da transformação.

Arantes (2000) ao apontar as conquistas dessa teoria no campo das pesquisas em psicologia moral afirma:

Do ponto de vista metodológico, o que nos atrai nessa teoria, e que constitui um grande avanço conceitual, é o fato de não trabalharmos com categorias prédeterminadas de modelos organizadores. Eles são extraídos a partir das respostas dos sujeitos e não por inferências prévias do pesquisador. Isso significa que os modelos encontrados não se repetem necessariamente em outras situações e com outra amostra.

ARANTES, 2000, p. 144.

É a partir das inovações e possibilidades desse novo recurso de análise e investigação do psiquismo humano, em toda a sua complexidade e riqueza, que está fundamentada a parte prática do presente trabalho. 


\section{PESQUISA DE CAMPO}

\section{1. DEFINIÇÕES PRELIMINARES}

\section{1. A - Apresentação:}

O objeto central definido para o presente trabalho, foi identificar em adolescentes, submetidos a circunstâncias diversas de vulnerabilidade social, as possíveis representações que sustentam uma lógica coletiva de subordinação e hierarquização e que, de algum modo, ameaçam sua condição de legítimos detentores das garantias de igualdade e eqüidade, constitucionalmente afirmados.

Como objetivo específico buscou-se reconhecer crenças e valores que podem exercer influência na constituição subjetiva destes adolescentes e servir de parâmetro nas relações que estabelecem, envolvendo seus papéis sociais de gênero, especialmente as afetivas, entendendo que sua possível identificação contribua, de algum modo, para o aprofundamento de estudos que procurem reconhecer a influência das representações sociais de gênero, em sujeitos adolescentes, na resolução de seus conflitos de ordem "intra" e "inter" pessoal.

A variável com a qual se pretendeu subsidiar a investigação, no escopo do presente trabalho, foi identificar as idéias centrais que sustentam juízos de valor cuja lógica fomenta disparidades, associadas às feminilidades e/ou às masculinidades, em um momento expressivo da construção dos significados que inferem aos papéis de gênero.

\section{1. B - Definição da questão central de pesquisa:}

Assumindo a igualdade de direitos como prerrogativa das sociedades democráticas, o objetivo central da presente pesquisa foi identificar variáveis que pudessem ameaçar um dos pressupostos primários da convivência pacífica e equânime entre todos os seres humanos.

Partindo das afirmações da Declaração Universal dos Direitos Humanos de que todos os seres humanos são iguais em direitos e deveres e que devem ter garantido o direito às condições para o exercício pleno das prerrogativas da sua liberdade, que instâncias da formação dos sujeitos podem estar ameaçando esta condição inalienável?

O que gera a ruptura da igualdade "natural" que existe entre meninos e meninas na infância? Existem, de fato, modelos patriarcais ou outras formas hierárquicas de subordinação sendo naturalizados e banalizados?

Entendendo a Educação e a socialização como formas privilegiadas de intervenção para garantir a igualdade entre os gêneros, definimos como objetivos específicos investigar 
junto a jovens pré-adolescentes, entre 11 e 15 anos, de ambos os sexos, estudantes de uma escola pública localizada na periferia de um grande centro urbano, os atributos de gênero, associados aos sexos, que eventualmente ameaçam a igualdade e a eqüidade entre os gêneros.

Partimos da hipótese de que pode haver alguma espécie de estatuto a definir padrões socialmente aceitos para as questões de gênero e que, durante a formação de nossos jovens, os sujeitos têm uma relativa tendência a "acatá-los" como norma para as noções de pertencimento a este ou aquele grupo, fenômeno este que contribui para a banalização da subordinação e hierarquização de certos atributos, associados às feminilidades e às masculinidades.

Compreender como os jovens se vêem em seu próprio papel de gênero, como são vistos e como reconhecem o outro, foi uma das prerrogativas da nossa pesquisa de campo. De maneira complementar a tais questões, instituímos, na interação entre os papéis, a iminência de um conflito como subsídio para tentar identificar as variáveis que podem reger relações interpessoais a partir da lógica dos papéis sociais de gênero.

\section{1. C - Antecedentes}

A presente pesquisa, especialmente naquilo que tange à definição do recorte a ser investigado, foi, até certa medida, influenciada por pesquisa anterior realizada no primeiro semestre de 2005.

Naquela ocasião, em função do interesse em aprofundar os conhecimentos acadêmicos no campo da Psicologia Moral, participamos de projeto coordenado pela Professora Doutora Valéria Amorim Arantes, orientadora tanto do nosso Trabalho de Conclusão de Curso (Licenciatura Plena em Pedagogia) - TCC -, quanto do atual programa de Mestrado, ocasião na qual pesquisávamos, junto a jovens adolescentes, a influência de algumas das representações coletivas que permeariam a constituição psíquica daqueles que vivenciavam um momento decisivo da construção de seus papéis sociais, especialmente naquilo que tange ao gênero.

Até então não nos havia ocorrido a relevância dos estudos desta área.

No entanto, à medida que o trabalho foi avançando, foi possível perceber que a maior parte dos mecanismos sociais, instituídos historicamente, parece de fato estabelecer uma lógica social de privilégios, dominação e subjugação que, não só parece estar de algum modo sendo legitimada por algumas das práticas do cotidiano de nossas escolas, tanto quanto o possa ser em qualquer outra instituição, mas que, de forma ainda mais alarmante, vem sendo mantida pelos próprios sujeitos, por intermédio de reproduções, quase sempre inconscientes, 
de valores, muitas das vezes, não condizentes com as demais conquistas humanas alcançadas e, neste caso específico, das sociedades patriarcais mais tradicionais.

A questão central que, então, se buscou identificar foi a forma como, adolescentes de ambos os sexos, percebiam, respectivamente, os papéis de gênero em um momento de significação profunda para a sua constituição psíquica, e de maneira especial como poderiam aqueles, eventualmente, interferir nas interações entre o sexo feminino e o sexo masculino, no confronto de interesses distintos.

O instrumento utilizado, na ocasião, foi a narrativa de um conflito, vivenciado por uma jovem que, ainda que não tivesse declarado a sua idade, em seu relato conduzia à impressão de ser próxima àquela dos entrevistados. Tratava-se de um conflito de interesses entre a protagonista e um rapaz.

No desenvolvimento de sua argumentação, Laura, a narradora, deixa claras as suas necessidades e a forma impositiva com que Bruno, o rapaz, impõe os seus próprios objetivos.

A certa altura Laura é agredida por Bruno.

$\mathrm{Na}$ seqüência do trabalho de pesquisa, foi solicitado que os entrevistados se colocassem no lugar da jovem e sugerissem a melhor atitude a ser tomada.

Alguns dos nossos resultados merecem destaque.

De modo geral as meninas apresentaram uma tendência a respostas menos agressivas que os meninos. Não esboçaram reações em sua defesa. Não aventaram o revide ou qualquer outro tipo de violência, sequer pensaram na hipótese da "legítima defesa", elemento esse que só apareceu nas respostas masculinas.

Outro aspecto relevante encontrado foi o fato de que a indignação frente à agressão do rapaz teve uma tendência decrescente inversamente proporcional à variável idade, fenômeno particularmente marcante na amostra feminina, especialmente a partir dos catorze anos, período em que a tendência efetivamente se inverteu.

Também pareceu merecer aprofundamento a questão referente à hipótese de que o problema teria surgido em conseqüência da falta de diálogo entre os protagonistas e de que a responsabilidade, pela busca de entendimento, caberia única e exclusivamente à Laura.

Pareceu crescente a tendência à naturalização da violência à medida que as jovens se apropriavam, efetivamente, das expectativas relacionadas a seu papel de gênero.

Evidenciou-se, entre as meninas uma tendência crescente, diretamente proporcional à variável idade, em naturalizar a agressão. O desprezo pela atitude de Bruno que fora manifestado aos doze anos não foi encontrado nas respostas da amostra feminina aos dezesseis anos. 
As meninas pareceram mais propensas à dúvida moral, especialmente quando se tratou de questionar os motivos que poderiam ter levado Bruno a cometer a agressão, aparentemente dando uma chance para que ele pudesse se justificar. Esses índices demonstraram que aos dezesseis anos havia uma tendência maior a considerar que as razões de Bruno pudessem, de algum modo, amenizar a agressão sofrida inclusive possibilitando a reconciliação, alternativa que também não foi encontrada na amostra masculina.

Os dados coletados pareceram confirmar a hipótese de que há, de fato, uma formação social voltada para a submissão feminina aos interesses do papel masculino e que é possível ocorrer algum tipo de "adaptação" desse papel, assumido pelas jovens do sexo feminino, especialmente a partir dos catorze anos, aos interesses expressos nas atitudes masculinas, ainda que os mesmos possam ameaçar os seus direitos ou a sua integridade física.

Em função da tendência identificada anteriormente, definimos para a presente investigação um recorte com adolescentes cuja faixa etária antecedesse àquela da pesquisa precedente de maneira a confirmar a hipótese levantada de que poderia ser crescente, de maneira diretamente proporcional à idade, a tendência à naturalização da subordinação dos interesses das jovens do sexo feminino, em relação aos jovens do sexo masculino.

\section{1. D - Recorte adotado}

A escola selecionada para a presente pesquisa é, também, uma instituição pública, desta feita, vinculada à rede municipal de ensino da cidade de São Paulo, e está jurídica e legalmente subordinada à Coordenadoria de Ensino Jaçanã/Tremembé.

Nos últimos meses de 2006 integrou-se a um projeto que teve por eixo temático a questão da "Educação comunitária e a construção de valores de Democracia e de Cidadania”, uma pesquisa financiada pela Fundação de Amparo à Pesquisa do Estado de São Paulo - FAPESP -, na categoria "Melhoria do Ensino Público", fruto da parceria de professores pesquisadores vinculados à Faculdade de Educação (FE - USP) e à Escola de Artes, Ciências e Humanidades da Universidade de São Paulo (EACH - USP Leste), que se mobilizaram na iniciativa de buscar contribuir para a melhoria do ensino público, especialmente em seu nível básico, entendendo que o processo democrático e a educação para a cidadania são prerrogativas indispensáveis para superar as dificuldades educacionais brasileiras, especialmente no enfrentamento da desigualdade social.

Foram três subprojetos articulados, cada um com sua especificidade, de acordo com o coordenador $^{31}$ que os liderou, em torno da concepção de uma educação de qualidade, baseada

\footnotetext{
${ }^{31}$ Professore(a)s Dr(a)s. Ulisses Ferreira Araújo, Patrícia Junqueira Grandino e Valéria Amorim Arantes.
} 
em princípios da educação comunitária e da construção de valores democráticos, para a conquista efetiva da cidadania, e que se propuseram a incentivar, nas escolas parceiras, processos que estimulassem o protagonismo discente, na superação dos impasses educacionais vivenciados, especialmente nas periferias dos grandes centros urbanos.

Tais projetos tinham, como central, a proposta de desenvolver a conscientização dos pressupostos da cidadania e propunham uma concepção mais ampla que viria a envolver: "ética, convivência democrática, direitos humanos e inclusão social".

Esta escola, em particular, tornou-se parceira de um projeto coordenado pela Professora Doutora Valéria Amorim Arantes, sob o título "Educação comunitária e a construção de valores de Democracia e de Cidadania: questões de gênero na resolução de conflitos interpessoais". O projeto deste grupo de trabalho, iniciado efetivamente em janeiro de 2007 com duração de um ano, centrou-se na resolução de conflitos interpessoais em questões de gênero e se deu junto à equipe pedagógica da Escola Municipal de Ensino Fundamental João Ramos - Pernambuco - Abolicionista, situada à Rua João Nicolau Chamma, 239, Vila Albertina, São Paulo.

Ficou acordado que a escola parceira seria palco da aplicação de algumas pesquisas de campo de alunos da pós-graduação uma vez que a sua realização abriria a possibilidade de investigação dos reflexos de intervenções como proposta.

Para a presente pesquisa foram aplicados duzentos e cinqüenta e sete questionários em catorze turmas de quinta a oitava séries do Ensino Fundamental II dos quais foram efetivamente analisados duzentos e onze.

Os demais questionários foram desconsiderados por terem apresentado respostas incompletas, inconsistentes, ilegíveis, deliberadamente anuladas, ou pelo fato de seus respondentes estarem fora da faixa etária definida para o atual trabalho.

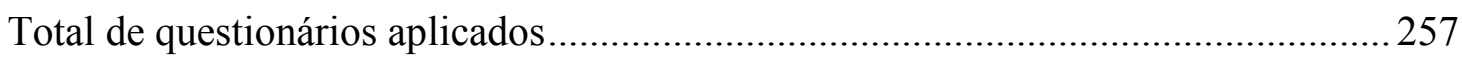

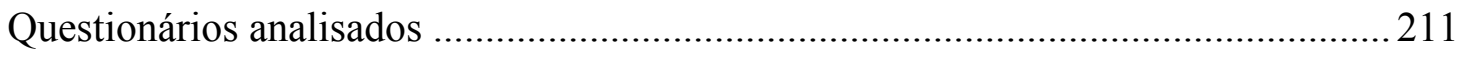

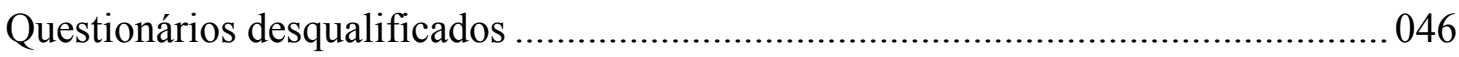

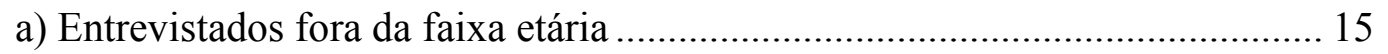

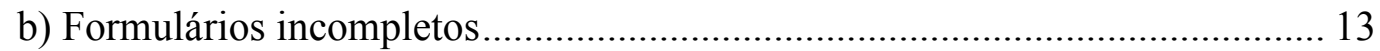

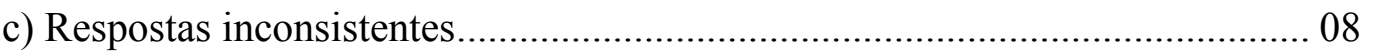

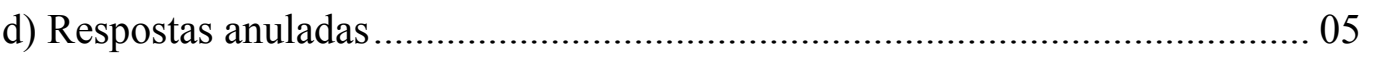

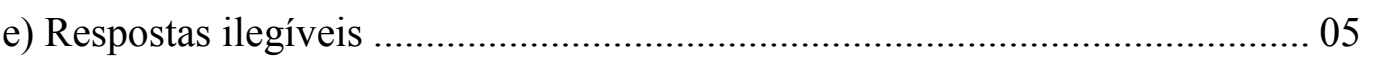

Resumidamente apresentamos um quadro em que estão detalhadas as condições de aplicação dos questionários: 


\begin{tabular}{|c|c|c|c|c|c|}
\hline \multirow[t]{2}{*}{ IDADE } & \multicolumn{4}{|c|}{ SEXO } & \multirow{3}{*}{$\begin{array}{c}\text { TOTAL } \\
57\end{array}$} \\
\hline & \multicolumn{2}{|c|}{ FEMININO } & \multicolumn{2}{|c|}{ MASCULINO } & \\
\hline \multirow[t]{2}{*}{11 anos } & $5^{\text {a }}$. S: 18 & \multirow[t]{2}{*}{29} & $5^{\text {a. }}$ S: 20 & \multirow[t]{2}{*}{28} & \\
\hline & 6. S: 11 & & 6a. S: 08 & & \\
\hline \multirow[t]{3}{*}{12 anos } & $5^{\text {a. }}$ S: 08 & \multirow[t]{3}{*}{30} & 5a. S: 09 & \multirow[t]{3}{*}{24} & \multirow[t]{3}{*}{54} \\
\hline & $6^{\text {a }}$ S: 19 & & $6^{\text {a }} . \mathrm{S}: 12$ & & \\
\hline & $7^{\text {a }}$. S: 03 & & $7^{\mathrm{a}}$. S: 03 & & \\
\hline \multirow[t]{4}{*}{13 anos } & $5^{\text {a }}$. S: 03 & \multirow[t]{4}{*}{20} & $5^{\text {a. }}$. S: 07 & \multirow[t]{4}{*}{27} & \multirow[t]{4}{*}{47} \\
\hline & 6. S: 05 & & 6a. S: 08 & & \\
\hline & $7^{\text {a. }}$ S: 09 & & $7^{\mathrm{a}}$. S: 12 & & \\
\hline & $8^{\text {a. }}$ S: 03 & & $8^{\text {a }}$. S: 00 & & \\
\hline \multirow[t]{4}{*}{14 anos } & $5^{\text {a }}$. S: 00 & \multirow[t]{4}{*}{22} & 5. S: 08 & \multirow[t]{4}{*}{17} & \multirow[t]{4}{*}{39} \\
\hline & 6. S: 03 & & 6. S: 02 & & \\
\hline & $7^{\text {a }}$. S: 03 & & $7^{\text {a. }}$ S: 03 & & \\
\hline & $8^{\text {a. }}$ S: 16 & & $8^{\text {a }}$. S: 04 & & \\
\hline \multirow[t]{3}{*}{15 anos } & $6^{\text {a. }}$ S: 02 & \multirow[t]{3}{*}{04} & $6^{\text {a. }}$. S: 01 & \multirow[t]{3}{*}{10} & \multirow[t]{3}{*}{14} \\
\hline & $7^{\text {a }}$. S: 00 & & $7^{\mathrm{a}}$. S: 03 & & \\
\hline & $8^{\text {a. }}$ S: 02 & & 8a S: 06 & & \\
\hline TOTAIS & \multicolumn{2}{|c|}{105} & & & 211 \\
\hline
\end{tabular}

Os sujeitos cujas respostas fizeram parte da presente análise foram distribuídos conforme proporção detalhada no quadro acima.

Todos os entrevistados contribuíram voluntariamente, após ter sido feito o convite para a participação, sendo permitida a retirada da sala para aqueles que não o quisessem. 


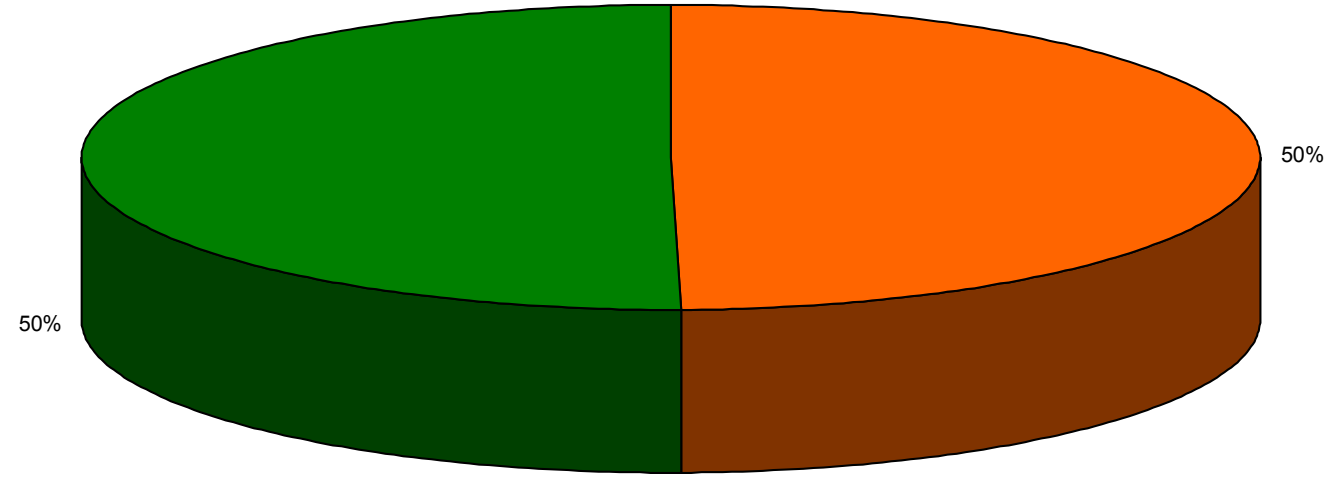

$\square$ Sexo Feminino $\square$ Sexo masculino

REPRESENTATIVIDADE DOS SUJEITOS - Faixa Etária/Sexo

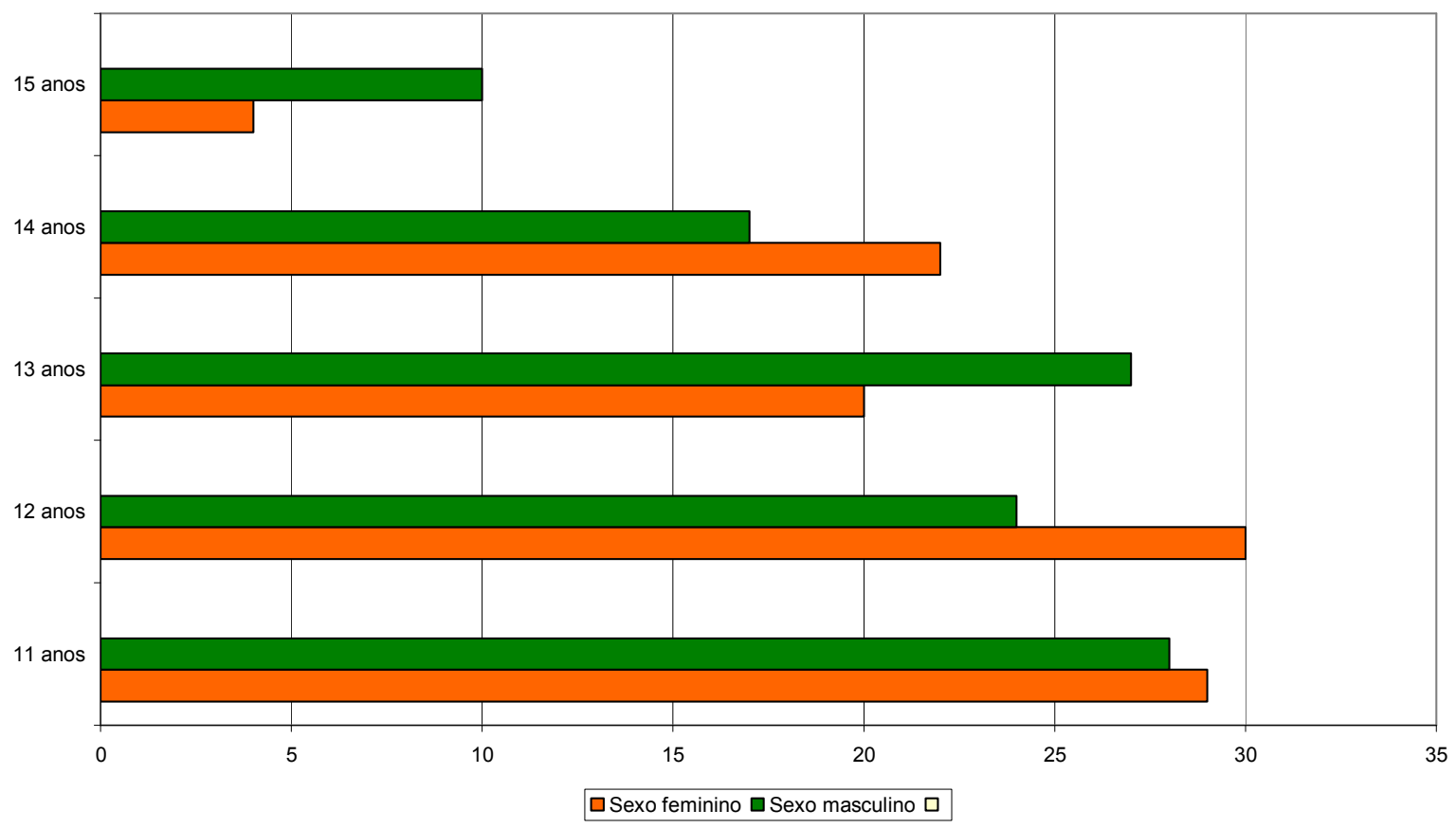




\section{1. E - Pressupostos metodológicos}

O objetivo central da presente pesquisa foi investigar a lógica inerente à legitimação de papéis sociais, relacionados ao gênero, na visão de adolescentes brasileiros, acatando possíveis vieses em relação a questões pertinentes ao sexo ou à sexualidade.

Adotamos como recorte uma amostra de jovens menos favorecidos, de ambos os sexos, com idade entre 11 e 15 anos, alunas e alunos regularmente matriculados em uma escola pública da cidade de São Paulo.

A opção pela escola na qual aplicamos a nossa pesquisa, se deveu, em parte, ao fato de estar a mesma participando, naquela ocasião, de um projeto de pesquisa mais abrangente ${ }^{32}$, patrocinado pela Fundação de Amparo à Pesquisa do Estado de São Paulo - FAPESP - o que possibilitaria, futuramente, uma análise cruzada a partir de diferentes perspectivas.

Foram aplicados 257 questionários a alunas e alunos, presentes às atividades letivas da primeira semana do mês de junho de 2007, dos períodos matutino e vespertino, em uma unidade escolar pública municipal que atende a uma das comunidades das camadas populares urbanas da Zona Norte da cidade de São Paulo.

O questionário aplicado apresentou aos jovens dez afirmações incompletas sendo cinco delas relacionadas ao papel masculino e as outras cinco ao papel feminino.

A metodologia de pesquisa adotada é especialmente indicada para investigações que, como a nossa, se proponham a identificar valores subliminares que possam sustentar uma lógica intrínseca às manifestações mais explícitas do sujeito uma vez que permite direcionar a opinião expressa em suas respostas para o foco das questões centrais definidas pelo objeto da pesquisa.

A opção por coletar as respostas por intermédio de um questionário com perguntas semidirecionadas, a partir de afirmações incompletas a serem concluídas pelos respondentes, favoreceu que houvesse uma definição de atributos associados aos papéis de gênero procurando identificar padrões socialmente instituídos e que, eventualmente, possam estar sendo legitimados pelos jovens e, ainda, naturalizando a desigualdade e a hierarquização destes atributos.

O formulário aplicado teve a seguinte estrutura:

"Complete as frases abaixo com aquilo que você $\mathrm{acha}^{33}$ :

1) Homem que é homem é

\footnotetext{
${ }^{32}$ Conforme detalhado anteriormente no item III. 1. D.

${ }^{33}$ A orientação foi reforçada verbalmente explicando aos entrevistados que não haveriam respostas certas ou erradas e que lhes seria permitida emitir toda e qualquer opinião
} 
2) Mulher que é mulher é

3) Homem só é homem se

4) Mulher só é mulher se.

5) Todo homem para ser homem tem que

6) Toda mulher para ser mulher tem que

7) Homem quando briga com mulher é porque

8) Mulher quando briga com homem é porque.....

9) Homem quando briga com homem é porque

10) Mulher quando briga com mulher é porque

Propositadamente, as perguntas foram formuladas de maneira a acirrar uma possível distinção entre os sexos. Também, de maneira intencional, as perguntas relacionadas aos homens antecediam àquelas apresentadas em relação às mulheres de tal maneira que, intrinsecamente, pudéssemos sugerir haver de nossa parte, uma relativa preferência dos atributos masculinos em relação aos femininos, mais uma vez visando estimular evidências de uma possível diferença nas representações dos adolescentes.

Dos 257 questionários distribuídos 211 puderam ser validados. Entre as respostas não analisadas havia questionários cujas respostas eram ilegíveis, incompletas ou ainda aquelas que intencionalmente não atendiam aos objetivos centrais propostos ${ }^{34}$ para a presente pesquisa.

A primeira parte do questionário (perguntas de 1 a 6) apresentava uma relativa insistência em perguntas, aparentemente, muito próximas umas das outras, cuja formulação atendeu ao nosso objetivo de validar as afirmações e associações feitas pelos respondentes ${ }^{35}$. A segunda parte (perguntas de 7 a 10) visava identificar a maneira como os jovens interpretam situações de conflito de interesses relacionados aos papéis de gênero.

Cada respondente foi identificado em seu respectivo formulário de acordo com as características consideradas mais relevantes para a nossa análise. Este mesmo critério foi adotado como referência ao sujeito, sempre que houvesse citação de uma de suas respostas ${ }^{36}$.

Em primeiro lugar a identificação do sujeito é feita pelas letras "F" ou "M", de modo que fique explicitado pertencer, quer ao grupo de sexo feminino, quer ao grupo de sexo masculino, respectivamente. A referência seguinte diz respeito à idade do respondente. $\mathrm{Na}$

\footnotetext{
${ }^{34}$ Referimo-nos aqui a termos inadequados usados propositadamente.

${ }^{35}$ Conforme proposto nas pesquisas de Barbël Inhelder para identificação dos processos a que o sujeito recorre ao ser exposto a uma seqüência de desafios crescentes, conforme detalhado no item III.3.A.

${ }^{36}$ Considerando que o objeto central de nosso trabalho tenha sido investigar atributos relacionados pelos jovens à legitimação dos papéis de gênero não nos ativemos a possíveis questões da ordem da utilização imprópria dos recursos da nossa língua; no entanto, no intuito de explicitar a lógica intrínseca ao afirmado pelo respondente em algumas das citações apresentadas poderão ter sido feito ajustes ortográficos.
} 
seqüência aparece a série e a turma que o(a) jovem freqüentava por ocasião da pesquisa. Segue-se uma referência às condições específicas, semelhantes àquele adolescente, detalhando sua posição relativa frente aos demais. A última referência diz respeito à quantidade total de alunos(as) naquela condição, ou seja, participantes do mesmo sexo e da mesma faixa etária.

Assim sendo o sujeito F14.8B(1.7)16 é portanto uma estudante do sexo feminino, de catorze anos, freqüentadora da oitava série do Ensino Fundamental II, tendo sido encontradas dezesseis jovens em condições semelhantes. Está vinculada à turma B, onde foram obtidos sete formulários nas mesmas condições (sexo/faixa etária) e esta jovem, especificamente, foi a primeira a ser registrada das sete cujos questionários foram considerados.

Aos questionários obtidos foi aplicada a análise a partir do referencial dos modelos organizadores de pensamento.

Inicialmente para a tabulação dos dados foram avaliadas as respostas de 1 a 6 do questionário que propunham associações diretas e, posteriormente, as questões de 7 a 9 que pretendiam identificar juízos de valor dos jovens nas situações hipotéticas apresentadas.

Desta maneira, a nossa análise das respostas está dividida em duas etapas. A primeira dedicada aos atributos que os jovens associaram àquilo que entendiam por ser ou ter atitude de "homem" bem como ser ou ter atitude de "mulher", enquanto a segunda esteve focada na análise do julgamento inerente a uma possível justificativa, apresentada pelos jovens, para situações fictícias de um embate entre pares do mesmo sexo ou do sexo oposto.

Durante a análise das respostas da primeira etapa ficou evidenciado que a sua tabulação em pares de respostas, 1 e 2, 3 e 4, 5 e 6, respectivamente poderia trazer resultados mais instigantes em função daquilo que havíamos nos proposto a investigar. A opção de as questões serem avaliadas aos pares favoreceu surgirem, de forma mais marcante, atributos hierarquizados em relação aos papéis de gênero.

Este direcionamento remete-se à nossa intenção de pesquisar a possível influência de modelos desiguais de legitimação dos papéis pautados em atributos ou responsabilidades distintos, associados ao universo masculino e/ou ao universo feminino, cuja valoração freqüentemente tende a considerar superior ou priorizar o primeiro em detrimento do segundo, banalizando a desigualdade e naturalizando distinções e disparidades historicamente constituídas, a partir de justificativas as mais diversas, especialmente aquelas que se remetem a questões biológicas.

Tendo em vista o nosso interesse central para esta pesquisa em investigar crenças e valores associados à naturalização de possíveis desigualdades, na legitimação dos papéis 
sociais de gênero, na visão de adolescentes brasileiros menos favorecidos, ao final da primeira etapa da pesquisa dedicamo-nos a aprofundar a análise das afirmações feitas pelos jovens que haviam evidenciado algum tipo de hierarquização de atributos, apontados ao responder ao primeiro bloco de questões. Foram, portanto, apreciados, mais detalhadamente, 98 questionários para as considerações específicas da primeira etapa da análise. $\mathrm{O}$ aprofundamento em questão pretendeu identificar valores explicitados nas respostas e que pudessem apresentar significações distintas quando aplicados a um a outro papel de gênero.

A formulação das hipóteses de conflitos apresentadas nas questões de 7 a 10 atendeu a nosso objetivo de investigar a forma como os jovens interpretariam as situações propostas envolvendo conflito de interesses entre pares e acabou por favorecer a inferência dos respondentes a partir dos referenciais que aplicariam ao tentar justificar a situação que lhes fora apresentada.

Considerando que havíamos identificado anteriormente ${ }^{37}$ uma tendência crescente diretamente proporcional ao avanço da faixa etária - da banalização da agressão feita por um jovem do sexo masculino a uma jovem do sexo feminino, na presente pesquisa para além de buscar identificar tal fenômeno, quando aplicado a diferente faixa etária (neste caso iniciando e encerrando a amostra com adolescentes um ano mais jovens) interessava-nos incluir a possibilidade de identificar a tendência, quando de um conflito promovido por um agressor do sexo feminino em relação ao par do sexo masculino. Identificadas estas tendências, de maneira idêntica, pretendíamos buscar evidências da maneira como seriam interpretados conflitos entre pares do mesmo sexo, verificando se a lógica aplicada à primeira hipótese, de um agressor de sexo oposto seria reaplicada, de forma equivalente, nas hipóteses em que agressor e agredido pertencessem ao mesmo sexo.

A análise inicial desta segunda etapa, mais uma vez, apontou para a tendência de encontrarmos disparidades mais evidentes nas inferências dos jovens ao analisarmos as suas respostas em pares.

De maneira idêntica à primeira etapa de tabulação dos dados, a tabulação das respostas foi, portanto, feita em pares que, desta feita, foram novamente subdivididos para viabilizar as tabulações que evidenciassem a lógica específica de cada modelo. As questões 7 e 8 foram tabuladas e comparadas visando identificar a lógica inerente a cada uma das questões propostas. Posteriormente, na análise dos dados obtidos, as respostas obtidas nas afirmações dos respondentes foram confrontadas.

\footnotetext{
${ }^{37}$ Pesquisa realizada em 2005 para o Trabalho de Conclusão de Curso - TCC - do curso de Licenciatura Plena em Pedagogia junto à Faculdade de Educação da Universidade de São Paulo, conforme detalhado no item III.1.C.
} 
A mesma metodologia foi aplicada ao par subseqüente, questão 9 e questão 10 , visando obter resultados significativos em todas as suas combinações.

Em função de nosso interesse em avaliar um possível paralelismo na lógica aplicada às diferentes questões da segunda etapa de análise, definimos modelos cujo eixo poderia ser aplicado às quatro questões da segunda série de perguntas do questionário apresentado aos respondentes, em nossa pesquisa de campo. Neste sentido, os submodelos de cada um dos modelos resultantes de nossa análise poderão ter ou não incidências em uma ou outra questão específica. Este tipo de evento é decorrência do fato de poder haver uma lógica aplicada a uma das questões e não aplicada em outra.

Os resultados encontrados em cada um dos grupos de questões foram confrontados de forma a identificar os possíveis conflitos, inerentes à legitimação de papéis de gênero, durante a adolescência, pautada em preceitos distintos.

\section{2. RESULTADOS OBTIDOS}

\section{2. A - Descrição dos Agrupamentos}

Ainda que a opção de análise, a partir dos modelos organizadores de pensamento, tenha como pressuposto não partir de categorias pré-determinadas para organizar as respostas, ficou evidente que estas categorias pareciam pré-estabelecidas pelos próprios sujeitos respondentes com origem, possivelmente, em crenças e valores significativos de sua socialização.

Tais tendências orientaram os eixos centrais que acabaram sendo decisivos para o agrupamento das diferentes respostas obtidas.

A primeira etapa da pesquisa aplicada às questões de 1 a 6 nos permitiu agrupar as respostas em dois grandes grupos. Uma primeira tendência identificada foi o raciocínio dos sujeitos em associações indiretas da legitimação de papéis a partir de valores independentes das questões de gênero e que foi classificada como "Grupo A"; uma segunda tendência identificada foi aquela em que os sujeitos aplicaram associações diretas interdependentes às questões de gênero em si mesmas, que por sua vez ficou definida como sendo o "Grupo B".

Uma tendência, ainda mais marcante identificada no "Grupo B" foi o reconhecimento que, de fato, no escopo desta pesquisa, ficou evidenciado que a percepção dos sujeitos entrevistados, no que se refere às questões de gênero, estava, de algum modo, influenciada pela compreensão destes papéis em consonância com as linhas teóricas adotadas pelos clássicos da temática, ou seja, o papel de gênero esteve predominantemente ligado ao 
determinismo biológico em uma associação direta com o sexo ou a fatores relacionais, em que o papel de um se define na relação ao outro, em uma clara referência aos aspectos da interdependência da concepção de um para com o outro. Poucas foram as respostas que fizeram uma associação direta com a sexualidade.

A leitura das respostas de 7 a 10 do grupo de respondentes permitiu observar que havia, claramente, nesta série de questões a tendência de um grupo de adolescentes em assumir "um dos lados" do embate, de defesa do agressor ou do agredido, imputando-lhe um caráter de juízo de valor construído a partir das próprias referências e representações. A este tipo de respostas denominamos "Com juízo de valor" tendo sido as mesmas reunidas, para efeito de tabulação dos dados, no "Grupo A". Quando por outro lado, os jovens não evidenciavam ter assumido a defesa direta de nenhum dos envolvidos, ou ainda se, a sua afirmação não indicava uma concretização efetiva da atitude suposta, as afirmações foram denominadas "Sem juízo de valor" e agrupadas no "Grupo B”. Portanto, para a classificação adotada "Com juízo de valor", foi possível reconhecer explicitamente uma lógica intrínseca assumindo uma das posições, quer seja de defesa dos interesses do agressor ou do agredido, enquanto a denominação "Sem juízo de valor" foi empregada quando das respostas daqueles sujeitos que não evidenciavam ter assumido partido de nenhum dos personagens envolvidos, ou quando atribuíam a ambos a responsabilidade pelo acontecido.

Cabe alertar que, no caso das afirmações do "Grupo B", em algumas das respostas obtidas poderia ter sido inferida uma posição intrínseca ao proposto pelo respondente, posição esta que optamos em não adotar.

\section{2. B - Descrição dos modelos da primeira fase:}

\section{Primeira fase da análise}

\section{Respostas $1 / 2,3 / 4$ e $5 / 6$}

Conforme definido anteriormente a organização dos modelos encontrados para as respostas obtidas, para a primeira série de questões, foi reunido em dois grandes grupos.

O primeiro grupo de respostas foi aquele em que os respondentes priorizaram, em suas associações, alguma espécie de valor ${ }^{38}$, ao que tudo indica inerente às suas crenças, quanto ao que entendiam significar "ser mulher" ou "ser homem", em nossa sociedade.

\footnotetext{
${ }^{38}$ Segundo Araújo (2007, p. 19/20) um valor "é resultado, é construído com base nas projeções afetivas que o sujeito faz sobre objetos ou pessoas." Mais adiante esclarece que "do ponto de vista psicológico, é possivel o ser humano construir valores que não sejam morais." (p. 22) e complementa "entendemos que os valores $e$
} 
O segundo grupo de respondentes foi aquele que apontou atributos diretamente associados ao sexo, à sexualidade ou ao gênero para identificar aquilo que representaria para elas, ou eles, ser "uma mulher" ou ser "um homem".

Os dois grupos, "A" e "B", tiveram por sua vez subdivisões que acabaram por gerar os modelos organizadores de pensamento 1 e 2, e os modelos 3, 4 e 5 respectivamente. As respostas que não apresentaram evidências claras de uma coerência interna, na lógica adotada, são objeto do agrupamento "Outros".

\section{Grupo A - Associação indireta}

\section{Modelo 1: TRABALHO}

Total geral de respostas para este modelo: 36

$17 \%$ do total

Os sujeitos que aplicaram este modelo às perguntas propostas tiveram por prioridade o trabalho na legitimação dos papéis de gênero ${ }^{39}$.

Neste modelo foram obtidas respostas em que o trabalho era constituinte tanto para homens quanto para mulheres, submodelo $1 \mathrm{~A}(47,2 \%)^{40}$, apenas para homens, submodelo $1 \mathrm{~B}$ $(50 \%)$ e apenas para mulheres, submodelo $1 \mathrm{C}(2,8 \%)$.

Exemplos de respostas:

Submodelo 1A Sem hierarquia

"Homem que é homem é: trabalhador."

"Mulher que é mulher é: trabalhadora."

"Homem só é homem se: trabalhar."

"Mulher só é mulher se: trabalhar."

"Todo homem para ser homem tem que: ser trabalhador e honesto."

"Toda mulher para ser mulher tem que: ser trabalhadora e honesta."

$\mathrm{M} 11.5 \mathrm{~A}(4.4) 20$

OBS: O atributo do trabalho para a legitimação do papel feminino surgiu também em versões como mulher batalhadora, guerreira ou lutadora.

contravalores construídos vão se organizando em um sistema de valores e se incorporando à identidade das pessoas, às representações que elas fazem de si." (p. 23)

${ }^{39}$ Segundo Guedes (1997, p. 170) o trabalho (especialmente entre os jovens das camadas populares urbanas, do sexo masculino nesta faixa etária) representa um dos fundamentos de seus projetos de futuro. "(...) eles estão vivendo o início do longo (e doloroso) processo de separação da família na qual foram criados para, através da iniciação profissional e do namoro, construir as condições para constituir uma nova família que, de fato, será o fulcro de sua transformação num homem/traballhador."

${ }^{40}$ A representatividade apontada para cada uma das possibilidades de resposta obtida foi relativizada, indicando, portanto seu percentual em relação unicamente a este modelo organizador. 
Modelo 1A Com hierarquia

"Homem que é homem é: trabalhador."

"Mulher que é mulher é: trabalhadora."

"Homem só é homem se: trabalhar e se arrumar."

"Mulher só é mulher se: trabalhar e for limpinha."

"Todo homem para ser homem tem que: trabalhar e ser educado."

"Toda mulher para ser mulher tem que: trabalhar e cuidar da casa."

F13.5D(1.1)03

Submodelo 1B Sem hierarquia

"Homem que é homem é: trabalhador e honesto."

"Mulher que é mulher é: corajosa."

"Homem só é homem se: tiver responsabilidade."

"Mulher só é mulher se: sabe o que quer."

"Todo homem para ser homem tem que: ter as suas obrigações e se virar na vida."

"Toda mulher para ser mulher tem que: ter honestidade."

$\mathrm{F} 12.6 \mathrm{~B}(6.8) 19$

Submodelo 1B Com hierarquia

"Homem que é homem é: trabalhador."

"Mulher que é mulher é: cuida da casa."

"Homem só é homem se: trabalha e respeita a mulher."

"Mulher só é mulher se: respeita o seu homem."

"Todo homem para ser homem tem que: trabalhar e sustentar os filhos e a família."

"Toda mulher para ser mulher tem que: fazer tudo o que o homem quer."

M11.5D(5.6)20

Submodelo 1C Sem hierarquia

"Homem que é homem é: corajoso."

"Mulher que é mulher é: trabalhadeira e guerreira."

"Homem só é homem se: tratar bem os filhos e a esposa."

"Mulher só é mulher se: é batalhadora."

"Todo homem para ser homem tem que: respeitar a sua esposa e respeitar as dos amigos."

"Toda mulher para ser mulher tem que: ter responsabilidade e correr atrás dos seus interesses."

$\mathrm{F} 11.5 \mathrm{C}(2.3) 18$ 
Obs: Não houveram incidências do submodelo $1 \mathrm{C}$ com hierarquia de atributos.

\begin{tabular}{|c|c|c|c|c|c|c|c|c|c|c|c|}
\hline \multicolumn{4}{|c|}{ Submodelo 1A } & \multicolumn{4}{|c|}{ Submodelo 1B } & \multicolumn{4}{|c|}{ Submodelo $1 \mathrm{C}$} \\
\hline \multicolumn{4}{|c|}{17} & \multicolumn{4}{|c|}{18} & \multicolumn{4}{|c|}{1} \\
\hline \multicolumn{2}{|c|}{ Sem hierarquia } & \multicolumn{2}{|c|}{ Com hierarquia } & \multicolumn{2}{|c|}{ Sem hierarquia } & \multicolumn{2}{|c|}{ Com hierarquia } & \multicolumn{2}{|c|}{ Sem hierarquia } & \multicolumn{2}{|c|}{ Com hierarquic } \\
\hline \multicolumn{2}{|c|}{13} & \multicolumn{2}{|c|}{4} & \multicolumn{2}{|c|}{6} & \multicolumn{2}{|c|}{12} & \multicolumn{2}{|c|}{1} & \multicolumn{2}{|c|}{0} \\
\hline$F$ & $\mathrm{M}$ & $F$ & $\mathrm{M}$ & $\mathrm{F}$ & $M$ & $F$ & $\mathrm{M}$ & $F$ & $\mathrm{M}$ & $\mathrm{F}$ & $\mathrm{M}$ \\
\hline 4 & 9 & 2 & 2 & 6 & 0 & 5 & 7 & 1 & 0 & 0 & 0 \\
\hline
\end{tabular}

\section{Modelo 2: VIRTUOSIDADE}

Total geral de respostas para este modelo: 43

$20 \%$ do total

Os sujeitos que aplicaram este modelo às perguntas propostas associaram a legitimação dos papéis de gênero a uma qualidade da excelência humana dentro do princípio das virtudes ${ }^{41}$.

Foram agrupadas as respostas dos sujeitos que empregaram qualquer tipo de adjetivo tanto àquilo que lhes parecia inerente ao que entendiam por "ser mulher" tanto quanto para aquilo que associaram ao "ser homem".

Este modelo permitiu uma subdivisão que acabou sendo classificada em 4 submodelos.

O submodelo $2 \mathrm{~A}(18,6 \%)$ foi resultado do agrupamento das respostas que priorizaram a não violência contra a mulher como atributo decisivo. O submodelo $2 \mathrm{~B}$ ( $30,2 \%$ ) é aquele em que os sujeitos optaram pelo respeito ao outro ou a si mesmo como atributo indispensável. O submodelo 2C $(18,6 \%)$ teve como princípio central o caráter, a lisura, sendo em sua maior parte conseqüência de algum outro atributo. O submodelo 2D (32,6\%) é resultante do agrupamento das respostas daqueles sujeitos que citaram uma espécie de reputação como forma de legitimar um papel social, com freqüência decorrente de algum outro atributo, especialmente associada aquela à responsabilidade como fruto da maturidade.

Exemplos de respostas:

Submodelo 2A Sem hierarquia

"Homem que é homem é: não bate na mulher amada."

"Mulher que é mulher é: sabe se defender sozinha."

"Homem só é homem se: assume os atos dele."

"Mulher só é mulher se: assume os seus atos."

\footnotetext{
${ }^{41}$ A concepção à qual nos referimos tem seu referencial nas obras aristotélicas e especialmente no "Pequeno tratado das grandes virtudes"de André Comte-Sponville.
} 
"Todo homem para ser homem tem que: não brigar com as pessoas que estão a seu lado."

"Toda mulher para ser mulher tem que: pensar antes de agir."

$\mathrm{M} 12.6 \mathrm{~B}(4.5) 13$

Submodelo 2A Com hierarquia

"Homem que é homem é: não bate em mulher."

"Mulher que é mulher é: não provoca o homem."

"Homem só é homem se: não agride mulher."

"Mulher só é mulher se: não faz baixaria."

"Todo homem para ser homem tem que: ser gentil, humilde e honesto."

"Toda mulher para ser mulher tem que: ser bonita, gostosa e ter muita esperança."

F14.8A(4.9)16

Submodelo 2B Sem hierarquia

"Homem que é homem é: aquele que não é machista."

"Mulher que é mulher é: aquela que enfrenta os seus problemas de frente."

"Homem só é homem se: respeitar a mulher."

"Mulher só é mulher se: respeitar o homem."

"Todo homem para ser homem tem que: participar das decisões das mulheres com direito de concordar ou não e respeitando as decisões dos outros."

"Toda mulher para ser mulher tem que: participar das coisas respeitando a opinião dos outros."

$\mathrm{F} 14.8 \mathrm{~B}(3.7) 16$

Submodelo 2B Com hierarquia

"Homem que é homem é: respeita a privacidade dos outros."

"Mulher que é mulher é: leal a seus próximos."

"Homem só é homem se: respeita e é educado."

"Mulher só é mulher se: respeita e é educada."

"Todo homem para ser homem tem que: respeitar o próximo, se cuidar, se respeitar, ser vaidoso porque não é por ser homem que não pode se cuidar."

"Toda mulher para ser mulher tem que: ter honra, não ser barraqueira, ter dignidade e amor ao próximo."

$\operatorname{M1} 1.5 \mathrm{~B}(2.5) 20$

Submodelo 2C Sem hierarquia

"Homem que é homem é: gente fina." 
"Mulher que é mulher é: uma grande pessoa."

"Homem só é homem se: honesto."

"Mulher só é mulher se: honesta."

"Todo homem para ser homem tem que: estudar para ser um grande homem, por isso que eu falo para você estudar também."

"Toda mulher para ser mulher tem que: estudar para conseguir um emprego, se não tem estudo, não tem trabalho."

$\mathrm{M} 12.5 \mathrm{C}(5.5) 09$

Submodelo 2C Com hierarquia

"Homem que é homem é: um homem de palavra."

"Mulher que é mulher é: mulher de caráter."

"Homem só é homem se: trabalha e respeita a mulher."

"Mulher só é mulher se: faz os trabalhos da casa."

"Todo homem para ser homem tem que: trabalhar e cuidar das suas obrigações."

"Toda mulher para ser mulher tem que: não fazer safadeza, chifrar... tem que ser sincera."

F12.6C(5.7)19

Submodelo 2D Sem hierarquia

"Homem que é homem é: responsável."

"Mulher que é mulher é: independente."

"Homem só é homem se: for compreensivo."

"Mulher só é mulher se: é simpática."

"Todo homem para ser homem tem que: honrar o seu nome."

"Toda mulher para ser mulher tem que: assumir o que faz."

$\mathrm{F} 13.7 \mathrm{C}(2.2) 09$

Submodelo 2D Com hierarquia

"Homem que é homem é: não faz criancice."

"Mulher que é mulher é: não faz o que não deve."

"Homem só é homem se: assume o que faz."

"Mulher só é mulher se: sabe onde é o seu lugar."

"Todo homem para ser homem tem que: ser maior de idade."

"Toda mulher para ser mulher tem que: passar da fase da virgindade."

$\mathrm{F} 13.8 \mathrm{~A}(2.3) 03$ 


\begin{tabular}{|c|c|c|c|c|c|c|c|c|c|c|c|c|c|c|c|}
\hline \multicolumn{4}{|c|}{ Submodelo 2A } & \multicolumn{4}{|c|}{ Submodelo 2B } & \multicolumn{4}{|c|}{ Submodelo 2C } & \multicolumn{4}{|c|}{ Submodelo 2D } \\
\hline \multicolumn{4}{|c|}{8} & \multicolumn{4}{|c|}{13} & \multicolumn{4}{|c|}{8} & \multicolumn{4}{|c|}{14} \\
\hline \multicolumn{2}{|c|}{$\mathrm{S} /$ hierarquia } & \multicolumn{2}{|c|}{$\mathrm{C} /$ hierarquia } & \multicolumn{2}{|c|}{ S/ hierarquia } & \multicolumn{2}{|c|}{$\mathrm{C} /$ hierarquia } & \multicolumn{2}{|c|}{ S/ hierarquia } & \multicolumn{2}{|c|}{$\mathrm{C} /$ hierarquia } & \multicolumn{2}{|c|}{$\mathrm{S} /$ hierarquia } & \multicolumn{2}{|c|}{$\mathrm{C} /$ hierarquia } \\
\hline \multicolumn{2}{|c|}{4} & \multicolumn{2}{|c|}{4} & \multicolumn{2}{|c|}{6} & \multicolumn{2}{|c|}{7} & \multicolumn{2}{|c|}{1} & \multicolumn{2}{|c|}{7} & \multicolumn{2}{|c|}{8} & \multicolumn{2}{|c|}{6} \\
\hline $\mathrm{F}$ & $\mathrm{M}$ & $\mathrm{F}$ & $\mathrm{M}$ & $\mathrm{F}$ & $\mathrm{M}$ & $\mathrm{F}$ & $\mathrm{M}$ & $\mathrm{F}$ & $\mathrm{M}$ & $\mathrm{F}$ & $\mathrm{M}$ & $\mathrm{F}$ & $\mathrm{M}$ & $\mathrm{F}$ & $\mathrm{M}$ \\
\hline 2 & 2 & 2 & 2 & 5 & 1 & 2 & 5 & 0 & 1 & 2 & 5 & 7 & 1 & 2 & 4 \\
\hline
\end{tabular}

\section{Grupo B - Associação direta}

\section{Modelo 3: SEXO}

Total geral de respostas para este modelo: 81

$37 \%$ do total

Os sujeitos que aplicaram este modelo ao primeiro bloco de questões priorizaram as associações de ordem biológica.

Foram agrupadas neste modelo tanto as respostas que confirmaram a mesma tendência para as seis perguntas iniciais, quanto aquelas que, à medida em que havia a insistência para a confirmação dos atributos, migraram para opções associadas quer fosse à sexualidade ou às relações de gênero.

Desta característica surgem, portanto, respectivamente os submodelos $3 \mathrm{~A}$ representando $23,4 \%$ do total deste modelo, $3 \mathrm{~B}$ representando $26 \%$ e $3 \mathrm{C}$ com $50,6 \%$ das respostas.

Exemplos de respostas:

Submodelo $3 \mathrm{~A}$ Sem hierarquia

"Homem que é homem é: homem."

"Mulher que é mulher é: mulher."

"Homem só é homem se: for macho."

"Mulher só é mulher se: for fêmea."

"Todo homem para ser homem tem que: ter aquilo que todo homem."

"Toda mulher para ser mulher tem que: ter aquilo que toda mulher tem."

$\mathrm{F} 12.6 \mathrm{~B}(2.8) 19$

Submodelo 3A

"Homem que é homem é: homem."

"Mulher que é mulher é: mulher."

"Homem só é homem se: usar cueca."

"Mulher só é mulher se: usar fio dental." 
"Todo homem para ser homem tem que: ter vontade de fazer sexo."

"Toda mulher para ser mulher tem que: ter um homem."

$\mathrm{M} 13.5 \mathrm{~A}(3.3) 07$

Submodelo 3B Sem hierarquia

"Homem que é homem é: homem."

"Mulher que é mulher é: mulher."

"Homem só é homem se: gostar de mulher."

"Mulher só é mulher se: gostar de homem."

"Todo homem para ser homem tem que: se cuidar, ficar bonito e perfumado para atrair mulher."

"Toda mulher para ser mulher tem que: se cuidar, ficar bem vestida... cuidar de você mesma."

$\mathrm{F} 12.5 \mathrm{~A}(2.2) 08$

Submodelo 3B

Com hierarquia

"Homem que é homem é: macho."

"Mulher que é mulher é: fêmea."

"Homem só é homem se: namorar mulheres."

"Mulher só é mulher se: namorar homens."

"Todo homem para ser homem tem que: ser machão e brincalhão."

"Toda mulher para ser mulher tem que: ser frágil e delicada."

M13.7A(1.3)12

Submodelo 3C

Sem hierarquia

"Homem que é homem é: e ponto final."

"Mulher que é mulher é: já nasce mulher."

"Homem só é homem se: age como um homem."

"Mulher só é mulher se: age como uma mulher."

"Todo homem para ser homem tem que: nascer homem e saber como se trata uma mulher."

"Toda mulher para ser mulher tem que: ser uma mulher e não falar a frase clichê: 'Todo homem é igual'.'

$\mathrm{M} 13.6 \mathrm{C}(4.4) 08$

Submodelo 3C Com hierarquia

"Homem que é homem é: homem."

"Mulher que é mulher é: mulher e sabe o seu lugar." 
"Homem só é homem se: namorar."

"Mulher só é mulher se: souber beijar."

"Todo homem para ser homem tem que: comer uma mina."

"Toda mulher para ser mulher tem que: ser muito mulher na hora do rala-e-rola e não pode trair o cara."

$\operatorname{M15.8A(3.3)06}$

\begin{tabular}{|c|c|c|c|c|c|c|c|c|c|c|c|}
\hline \multicolumn{4}{|c|}{ Submodelo 3A } & \multicolumn{4}{|c|}{ Submodelo 3B } & \multicolumn{4}{|c|}{ Submodelo 3C } \\
\hline \multicolumn{4}{|c|}{19} & \multicolumn{4}{|c|}{21} & \multicolumn{4}{|c|}{41} \\
\hline \multicolumn{2}{|c|}{ Sem hierarquia } & \multicolumn{2}{|c|}{ Com hierarquia } & \multicolumn{2}{|c|}{ Sem hierarquia } & \multicolumn{2}{|c|}{ Com hierarquia } & \multicolumn{2}{|c|}{ Sem hierarquia } & \multicolumn{2}{|c|}{ Com hierarquia } \\
\hline \multicolumn{2}{|c|}{11} & \multicolumn{2}{|c|}{8} & \multicolumn{2}{|c|}{15} & \multicolumn{2}{|c|}{6} & \multicolumn{2}{|c|}{20} & \multicolumn{2}{|c|}{21} \\
\hline $\mathrm{F}$ & $\mathrm{M}$ & $\mathrm{F}$ & $\mathrm{M}$ & $\mathrm{F}$ & $\mathrm{M}$ & $\mathrm{F}$ & $\mathrm{M}$ & $\mathrm{F}$ & $\mathrm{M}$ & $\mathrm{F}$ & $\mathrm{M}$ \\
\hline 7 & 4 & 1 & 7 & 8 & 7 & 2 & 4 & 14 & 6 & 9 & 12 \\
\hline
\end{tabular}

Modelo 4: SEXUALIDADE

Total geral de respostas para este modelo: 02

$1 \%$ do total

A associação estabelecida por estes sujeitos foi uma relação direta com questões da sexualidade.

Encontramos uma única ocorrência da sexualidade mantida como sexualidade, submodelo 4A e outra que, quando da confirmação dos atributos, foi remetida a questões de sexo, submodelo 4B. Em ambos os casos os respondentes deixaram subentendida uma certa hierarquia em suas associações. Não houve ocorrências neste modelo sem que fosse estabelecida alguma hierarquia

Exemplos de respostas:

Submodelo 4A Com hierarquia

"Homem que é homem é: masculino, forte e corajoso."

"Mulher que é mulher é: feminina, linda e simpática."

"Homem só é homem se: gostar de namorar e não ligar para os outros."

"Mulher só é mulher se: gostar de namorar e não ligar para falatório."

"Todo homem para ser homem tem que: namorar, malhar e jogar futebol."

"Toda mulher para ser mulher tem que: ficar bonita e acreditar no homem."

$\mathrm{M} 12.6 \mathrm{~A}(4.5) 13$

Submodelo 4B Com hierarquia

"Homem que é homem é: gosta de mulher."

"Mulher que é mulher é: gosta de sexo." 
"Homem só é homem se: tem pinto."

"Mulher só é mulher se: tem buceta."

"Todo homem para ser homem tem que: gostar de mulher."

"Toda mulher para ser mulher tem que: saber o que é certo e o que é errado."

$\mathrm{M} 13.7 \mathrm{~B}(2.3) 12$

\begin{tabular}{|c|c|c|c|c|c|c|c|}
\hline \multicolumn{4}{|c|}{ Submodelo 4A } & \multicolumn{4}{|c|}{ Submodelo 4B } \\
\hline \multicolumn{4}{|c|}{01} & \multicolumn{4}{|c|}{01} \\
\hline \multicolumn{2}{|c|}{ Sem hierarquia } & \multicolumn{2}{|c|}{ Com hierarquia } & \multicolumn{2}{|c|}{ Sem hierarquia } & \multicolumn{2}{|c|}{ Com hierarquia } \\
\hline \multicolumn{2}{|c|}{0} & \multicolumn{2}{|c|}{1} & \multicolumn{2}{|c|}{0} & \multicolumn{2}{|c|}{1} \\
\hline $\mathrm{F}$ & $\mathrm{M}$ & $\mathrm{F}$ & M & $\mathrm{F}$ & M & $\mathrm{F}$ & $\mathrm{M}$ \\
\hline 0 & 0 & 0 & 1 & 0 & 0 & 0 & 1 \\
\hline
\end{tabular}

\section{Modelo 5: GÊNERO}

Total geral de respostas para este modelo: 45

$21 \%$ do total

Os sujeitos que aplicaram este modelo ao primeiro bloco de perguntas associaram à legitimação do "ser mulher" ou do "ser homem" atributos relacionados a questões de gênero dando um significado indireto às questões propostas. Além destas possibilidades, assumimos, também, em nossa análise, como atributos de gênero qualidades subentendidas freqüentemente ao feminino e ao masculino, no senso comum, tais como associações com propriedades físicas ao primeiro e com virilidade ao segundo.

Este modelo permitiu, em seu aprofundamento, identificar que parte dos respondentes, ao ratificar as suas representações, permaneceu em questões relacionadas ao próprio gênero. Uma parte remeteu-se ao sexo, outros jovens buscaram corroborar o gênero na sexualidade e por último, alguns adolescentes buscaram ancorar no trabalho a legitimação do gênero.

Estas confirmações deram origem aos submodelos $5 \mathrm{~A}$, gênero/gênero com 53,3\% das respostas dentro do modelo, 5B gênero/sexo representando 17,7\%, 5C gênero/sexualidade também com $17,7 \%$ e $5 \mathrm{D}$ gênero/trabalho totalizando $11,3 \%$ das respostas.

Exemplos de respostas:

Submodelo 5A Sem hierarquia

"Homem que é homem é: masculino."

"Mulher que é mulher é: feminina."

"Homem só é homem se: respeitar e cuidar da mulher."

"Mulher só é mulher se: der valor aos outros." 
"Todo homem para ser homem tem que: ser cavalheiro, companheiro, amoroso $e$ carinhoso."

"Toda mulher para ser mulher tem que: ser atenciosa, ter caráter e respeitar os outros."

$\mathrm{F} 11.6 \mathrm{C}(5.7) 11$

Submodelo 5A

Com hierarquia

"Homem que é homem é: corajoso."

"Mulher que é mulher é: peituda."

"Homem só é homem se: pegar mulher."

"Mulher só é mulher se: pegar homem."

"Todo homem para ser homem tem que: ser forte, musculoso e mulherengo."

"Toda mulher para ser mulher tem que: ser um mulherão... gostosa, vaidosa."

$\mathrm{M} 13.5 \mathrm{C}(2.2) 07$

Submodelo 5B

Sem hierarquia

"Homem que é homem é: um cavalheiro."

"Mulher que é mulher é: uma dama."

"Homem só é homem se: tiver pênis."

"Mulher só é mulher se: tiver vagina."

"Todo homem para ser homem tem que: ter coragem para enfrentar qualquer coisa para conquistar a mulher."

"Toda mulher para ser mulher tem que: enfrentar as diferenças para ser feliz ao lado da pessoa amada."

M13. 6A(1.3)08

Submodelo 5B

Com hierarquia

"Homem que é homem é: machão."

"Mulher que é mulher é: sensivel."

"Homem só é homem se: tem o negócio em pé."

"Mulher só é mulher se: arrumar um homem e não broxar."

"Todo homem para ser homem tem que: ser ele mesmo."

"Toda mulher para ser mulher tem que: ter feminilidade."

$\operatorname{M13.7D(2.3)12}$

Submodelo 5C Sem hierarquia

"Homem que é homem é: corajoso e educado."

"Mulher que é mulher é: simpática e inteligente." 
"Homem só é homem se: gostar de mulher."

"Mulher só é mulher se: gostar de homem."

"Todo homem para ser homem tem que: fazer o papel dele."

"Toda mulher para ser mulher tem que: fazer o papel dela."

F12.6C(4.7)19

Submodelo 5C

Com hierarquia

"Homem que é homem é: civilizado."

"Mulher que é mulher é: feminina."

"Homem só é homem se: beijar uma mulher."

"Mulher só é mulher se: beijar um homem."

"Todo homem para ser homem tem que: assumir o que faz."

"Toda mulher para ser mulher tem que: saber se comportar."

$\mathrm{M} 13.5 \mathrm{~A}(1.3) 07$

Submodelo 5D

Sem hierarquia

"Homem que é homem é: forte."

"Mulher que é mulher é: corajosa."

"Homem só é homem se: trabalhar e estudar."

"Mulher só é mulher se: estudar e trabalhar."

"Todo homem para ser homem tem que: ser trabalhador e não se encostar nas mulheres."

"Toda mulher para ser mulher tem que: ser honesta e corajosa."

F11.6C(4.7)11

Submodelo 5D

Com hierarquia

"Homem que é homem é: tem que ser corajoso."

"Mulher que é mulher é: tem que ser responsável."

"Homem só é homem se: ser valentão."

"Mulher só é mulher se: ser muito bela."

"Todo homem para ser homem tem que: trabalhar e ter responsabilidade."

"Toda mulher para ser mulher tem que: saber cozinhar e ser delicada."

$\mathrm{F} 11.5 \mathrm{D}(4.5) 18$ 


\begin{tabular}{|c|c|c|c|c|c|c|c|c|c|c|c|c|c|c|c|}
\hline \multicolumn{4}{|c|}{ Submodelo 5A } & \multicolumn{4}{|c|}{ Submodelo 5B } & \multicolumn{4}{|c|}{ Submodelo 5C } & \multicolumn{4}{|c|}{ Submodelo 5D } \\
\hline \multicolumn{4}{|c|}{24} & \multicolumn{4}{|c|}{8} & \multicolumn{4}{|c|}{8} & \multicolumn{4}{|c|}{5} \\
\hline \multicolumn{2}{|c|}{$\mathrm{S} /$ hierarquia } & \multicolumn{2}{|c|}{$\mathrm{C} /$ hierarquia } & \multicolumn{2}{|c|}{ S/ hierarquia } & \multicolumn{2}{|c|}{$\mathrm{C} /$ hierarquia } & \multicolumn{2}{|c|}{$\mathrm{S} /$ hierarquia } & \multicolumn{2}{|c|}{$\mathrm{C} /$ hierarquia } & \multicolumn{2}{|c|}{ S/ hierarquia } & \multicolumn{2}{|c|}{$\mathrm{C} /$ hierarquia } \\
\hline \multicolumn{2}{|c|}{17} & \multicolumn{2}{|c|}{7} & \multicolumn{2}{|c|}{4} & \multicolumn{2}{|c|}{ 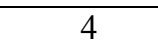 } & \multicolumn{2}{|c|}{5} & \multicolumn{2}{|c|}{3} & \multicolumn{2}{|c|}{2} & \multicolumn{2}{|c|}{3} \\
\hline $\mathrm{F}$ & $\mathrm{M}$ & $\mathrm{F}$ & $\mathrm{M}$ & $\mathrm{F}$ & $\mathrm{M}$ & $\mathrm{F}$ & $\mathrm{M}$ & $\mathrm{F}$ & M & $\mathrm{F}$ & $\mathrm{M}$ & $\mathrm{F}$ & $\mathrm{N}$ & $\mathrm{F}$ & $\mathrm{M}$ \\
\hline 8 & 9 & 3 & 4 & 2 & 2 & 0 & 4 & 0 & 5 & 0 & 3 & 1 & 1 & 1 & 2 \\
\hline
\end{tabular}

\section{Outros}

Outras associações.

Total geral de respostas nesta condição: 08

$4 \%$ do total

Os adolescentes que optaram por fazer associações nas quais não se remetiam diretamente à legitimação de gênero, independentemente do papel sugerido pelo instrumento, tiveram as suas respostas classificadas na categoria "Outros". Este agrupamento não tem subdivisões em função de sua peculariedade.

Exemplo de respostas.

Modelo 6 Sem hierarquia

"Homem que é homem é: aquele que luta por seus direitos sem se importar com o que os outros dizem."

"Mulher que é mulher é: aquela que luta por seus direitos sem se importar com a opinião dos outros."

"Homem só é homem se: fizer o possível para ser honesto, é digno da familia que tem e faz de tudo para cuidar da sua família (se tiver)."

"Mulher só é mulher se: fizer o possível para ser honesta, ser caridosa e amorosa com todos e cuidar bem dos seus filhos (se tiver)."

"Todo homem para ser homem tem que: ser ele mesmo e fazer o que o seu coração mandar."

"Toda mulher para ser mulher tem que: ser ela mesma e fazer o que o seu coração mandar."

$\mathrm{F} 12.7^{\mathrm{a}}(2.2) 03$

Modelo 6 Com hierarquia

"Homem que é homem é: briga pelo que tem."

"Mulher que é mulher é: briga pelo seu homem."

"Homem só é homem se: tem coragem para enfrentar o mundo." 
"Mulher só é mulher se: é corajosa."

"Todo homem para ser homem tem que: lutar contra o mundo."

"Toda mulher para ser mulher tem que: ser fiel ao marido e ser boa dona de casa."

F12. 6B(1.8)19

\begin{tabular}{|c|c|c|c|}
\hline \multicolumn{3}{|c|}{ Outros } \\
\hline \multicolumn{2}{|c|}{8} \\
\hline Com hierarquia & Sem hierarquia \\
\hline \multicolumn{2}{|c|}{2} & $\mathrm{~F}$ & $\mathrm{M}$ \\
\hline $\mathrm{F}$ & 0 & 5 & 1 \\
\hline 2 & & 5 & \multicolumn{2}{c|}{} \\
\hline
\end{tabular}

\section{Comentários sobre os dados obtidos}

De maneira resumida apresentamos os resultados obtidos nas perguntas que foram objeto da nossa análise, na primeira fase de tabulação dos questionários.

As seis perguntas iniciais propunham uma associação com os papéis de gênero de maneira intencionalmente polarizada nas questões apresentadas aos respondentes. Interessavanos sobremaneira desvelar as representações e as prescrições que estes jovens fariam ao completar as afirmações lançadas.

Os dois primeiros gráficos apresentados referem-se à maneira como os jovens entenderam ser possível legitimar os papéis de gênero, demonstrando as principais tendências encontradas nos modelos aplicados, de acordo com a lógica inferida às questões de 1 a 6 . Efetivamente, o primeiro totalizando genericamente as respostas obtidas (Gráfico 1), enquanto o segundo detalha a aplicação da hierarquização de atributos de acordo com o sexo do respondente (Gráfico 2). Em seguida apresentamos o detalhamento dos modelos aplicados, demonstrando as tendências de hierarquização dos atributos dentro de cada modelo (Gráfico 3), complementado pelo apontamento da distribuição daqueles atributos hierarquizados de acordo com o sexo dos jovens participantes de nossa pesquisa (Gráfico 4). É objeto dos gráficos 5 e 6 a hierarquização de atributos, compondo as variáveis sexo e faixa etária, primeiramente das adolescentes do sexo feminino, seguido pelo detalhamento dos jovens do sexo masculino, respectivamente. A distribuição dos atributos hierarquizados de acordo com a faixa etária está detalhada no gráfico 7 . O gráfico seguinte, de número 8 , compõem as variáveis sexo, faixa etária e hierarquização. O gráfico 9 detalha a incidência dos modelos 
aplicados de acordo com a idade, finalizando os gráficos de 10 a 14 com a distribuição relativa dos modelos, aplicados de acordo com a idade dos respondentes.

\section{Gráfico 1}

MODELOS APLICADOS

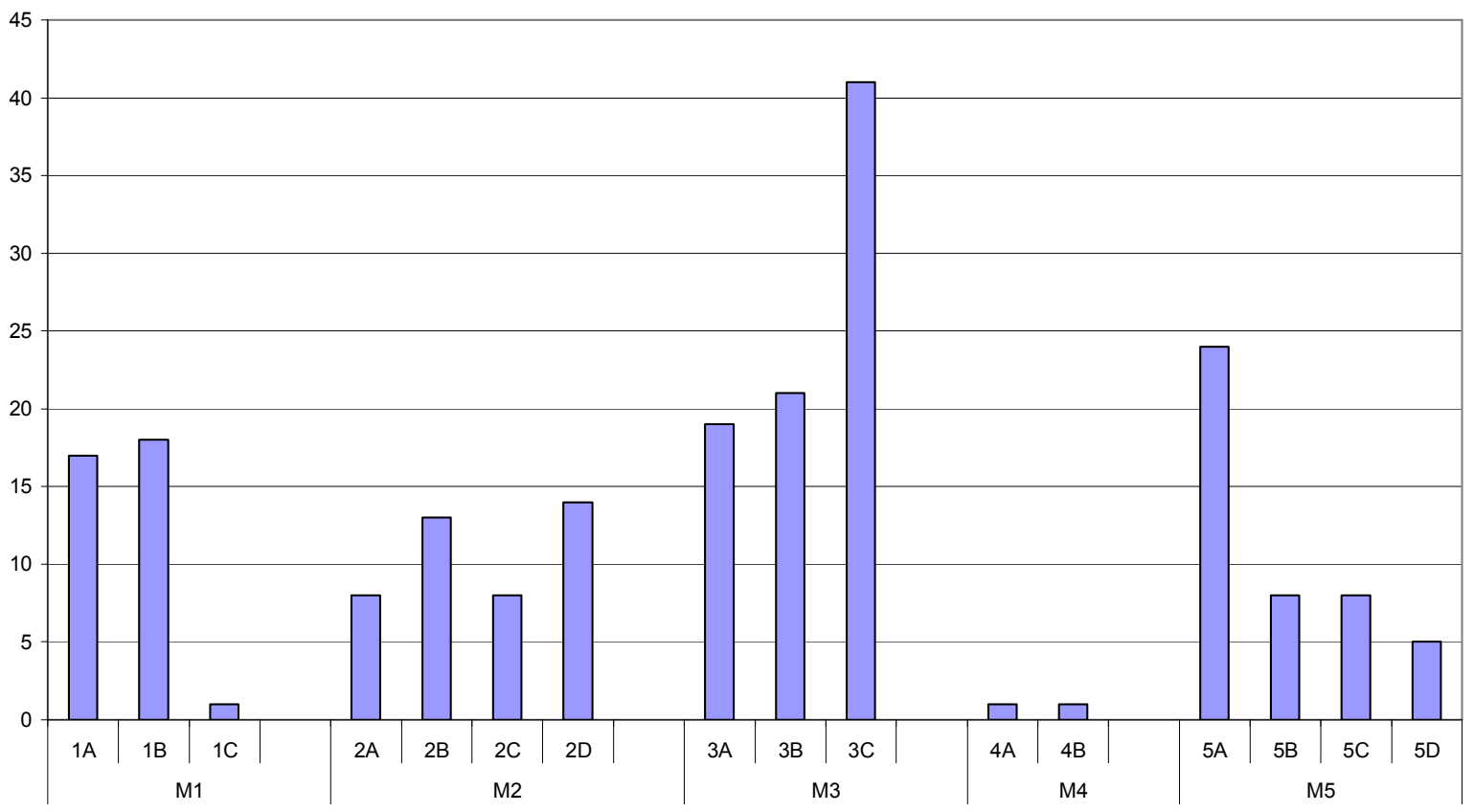

Gráfico 2

MODELOS APLICADOS POR SEXO

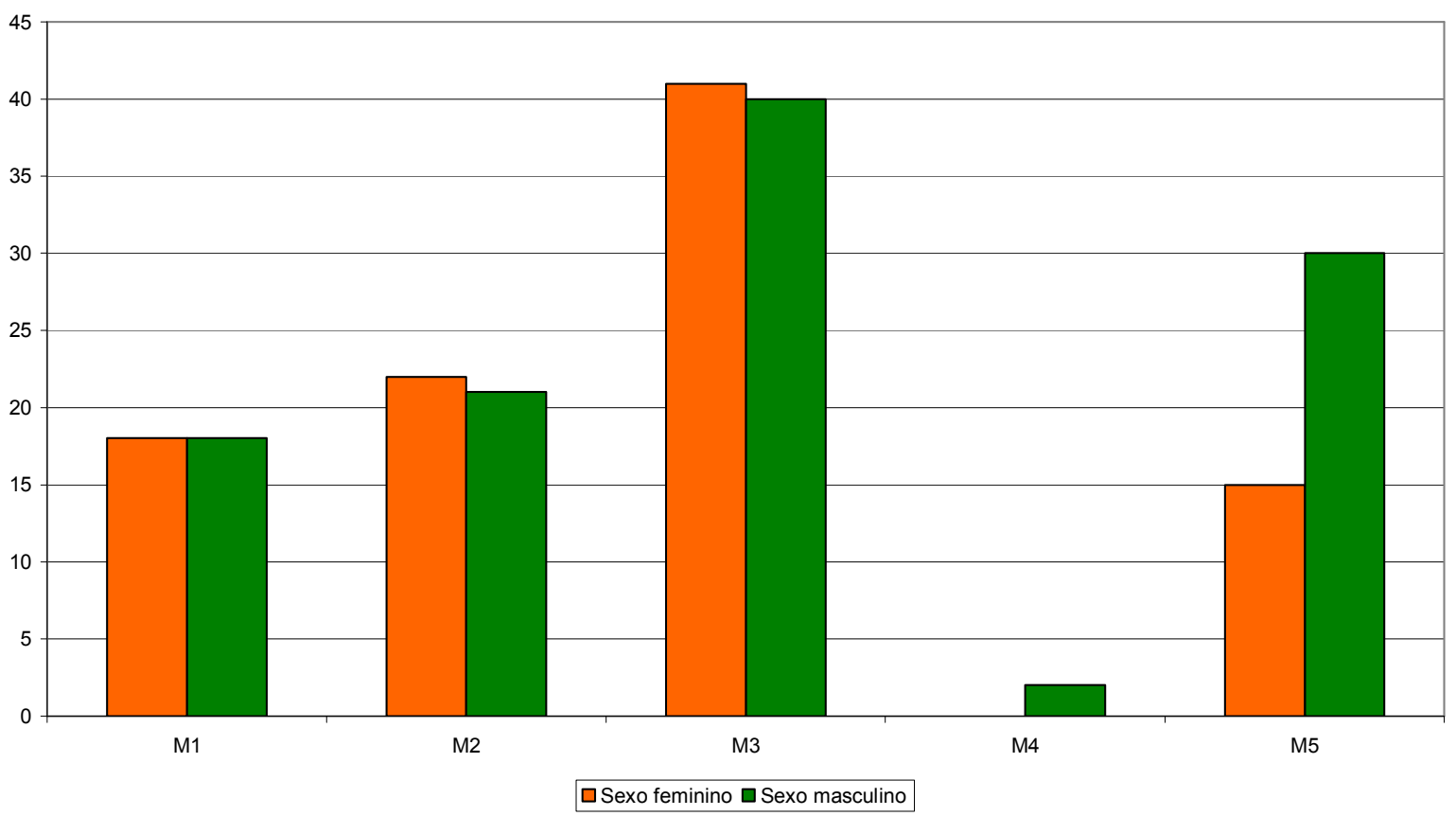

Modelo 1: Trabalho

Modelo 2: Virtudes

Modelo 3: Sexo 


\section{Gráfico 3}

MODELOS APLICADOS

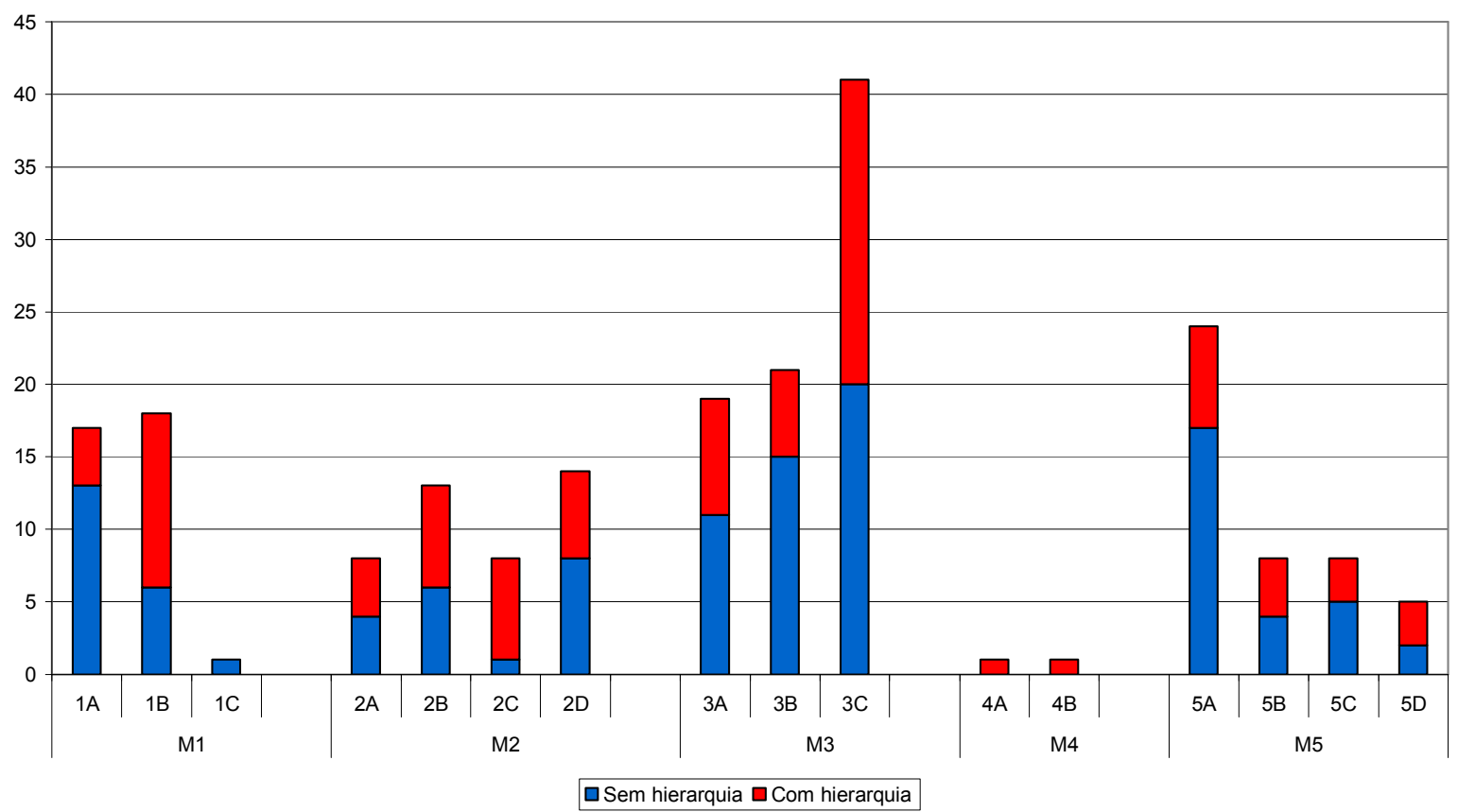

Modelo 1: Trabalho

Modelo 2: Virtude

Modelo 3: Sexo

Modelo 4: Sexualidade

Modelo 5: Gênero

\section{Gráfico 4}

HIERARQUIZAÇÃO POR SEXO

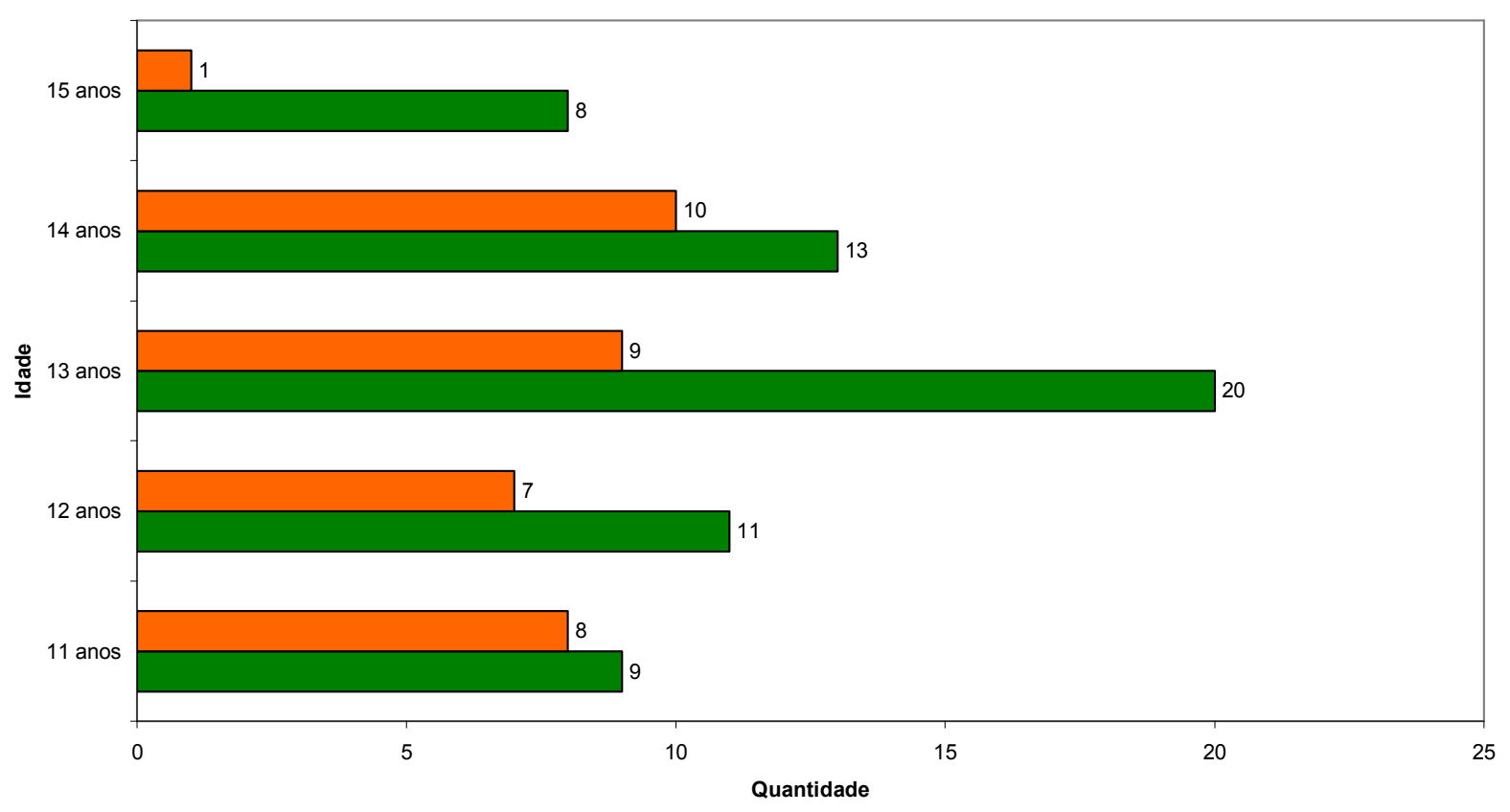

$\square$ Sexo masculino $\square$ Sexo feminino 


\section{Gráfico 5}

Hierarquização sexo feminino

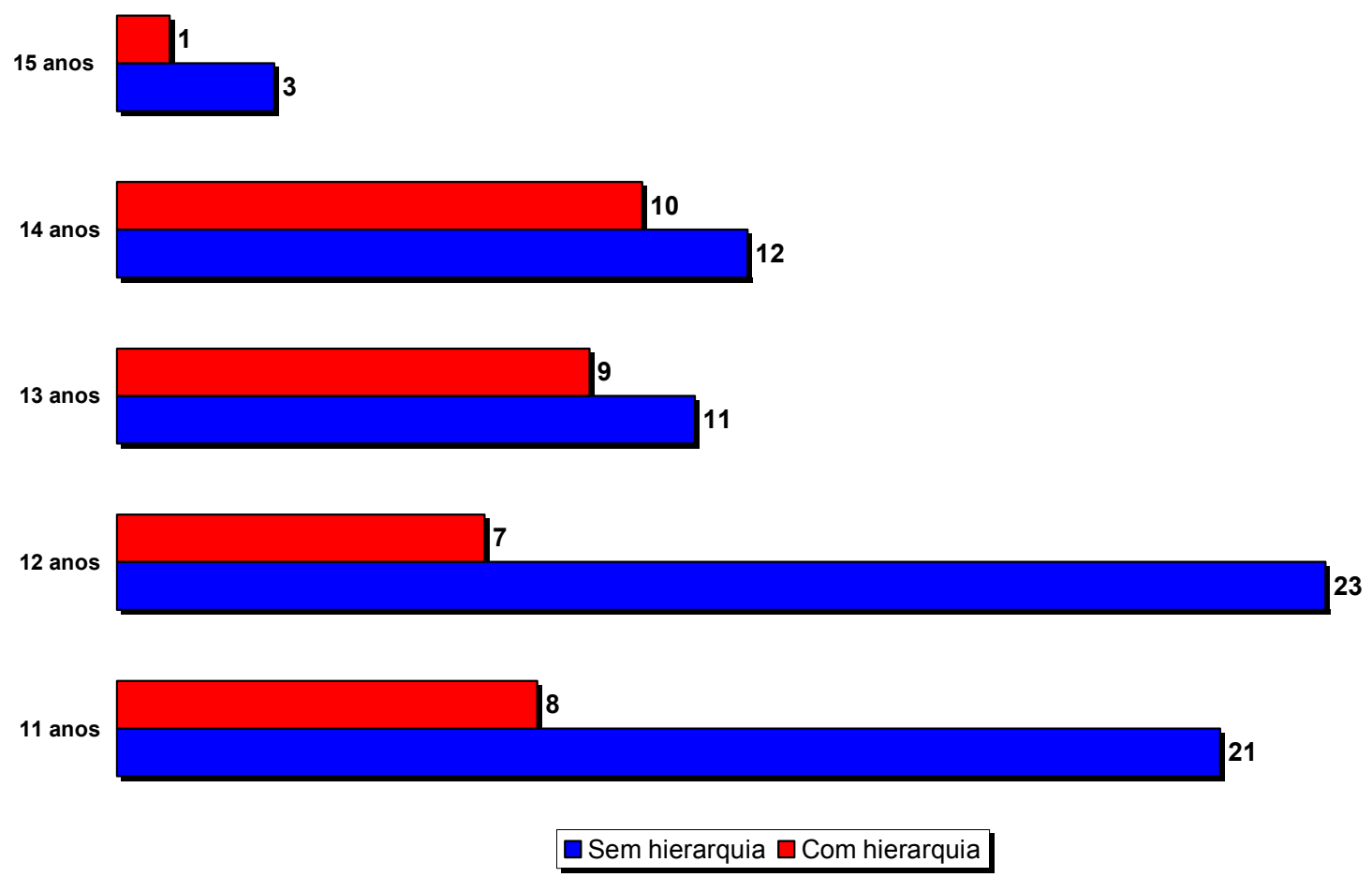

\section{Gráfico 6}

Hierarquização sexo masculino

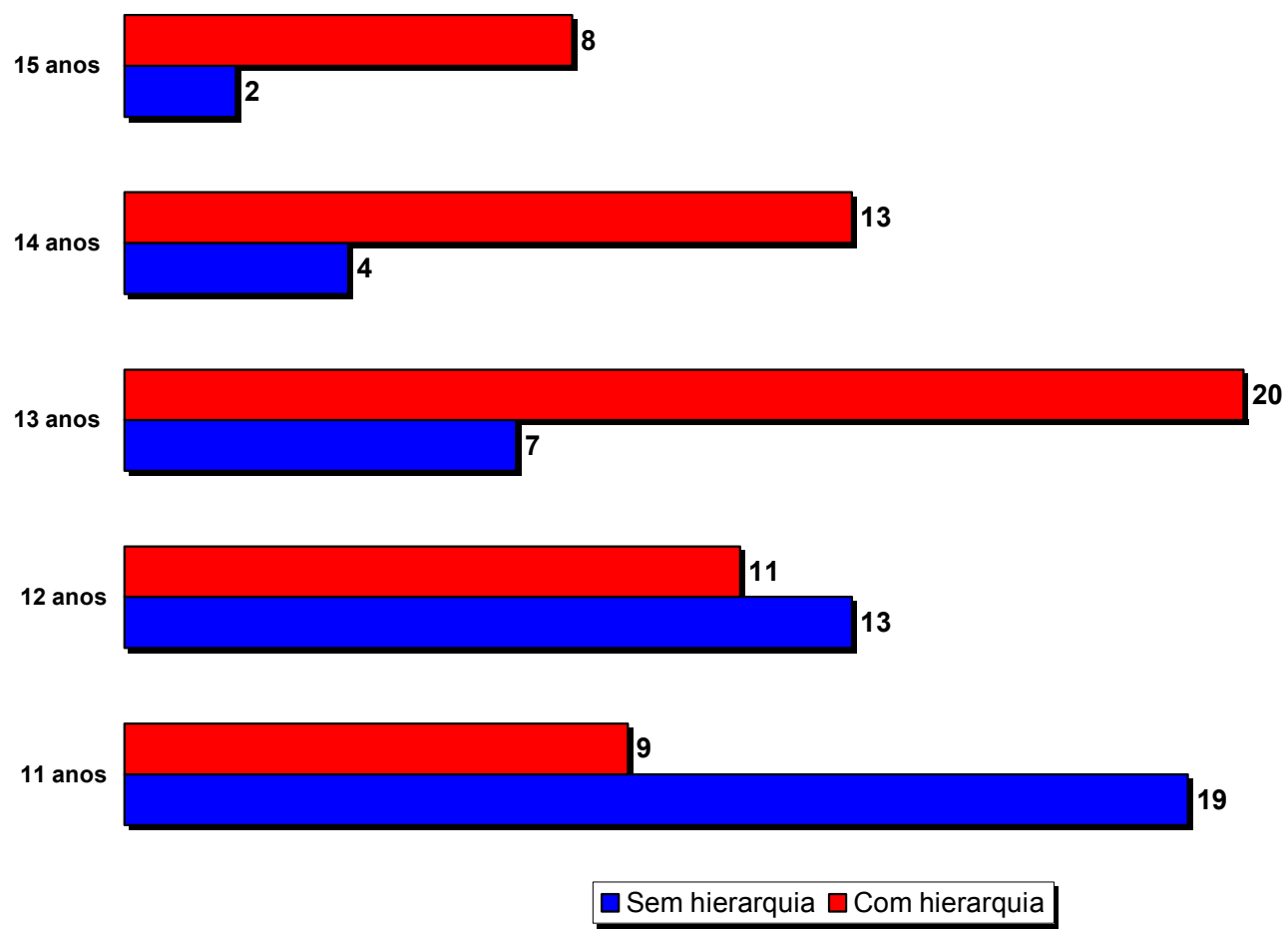




\section{Gráfico 7}

Hierarquização por faixa etária

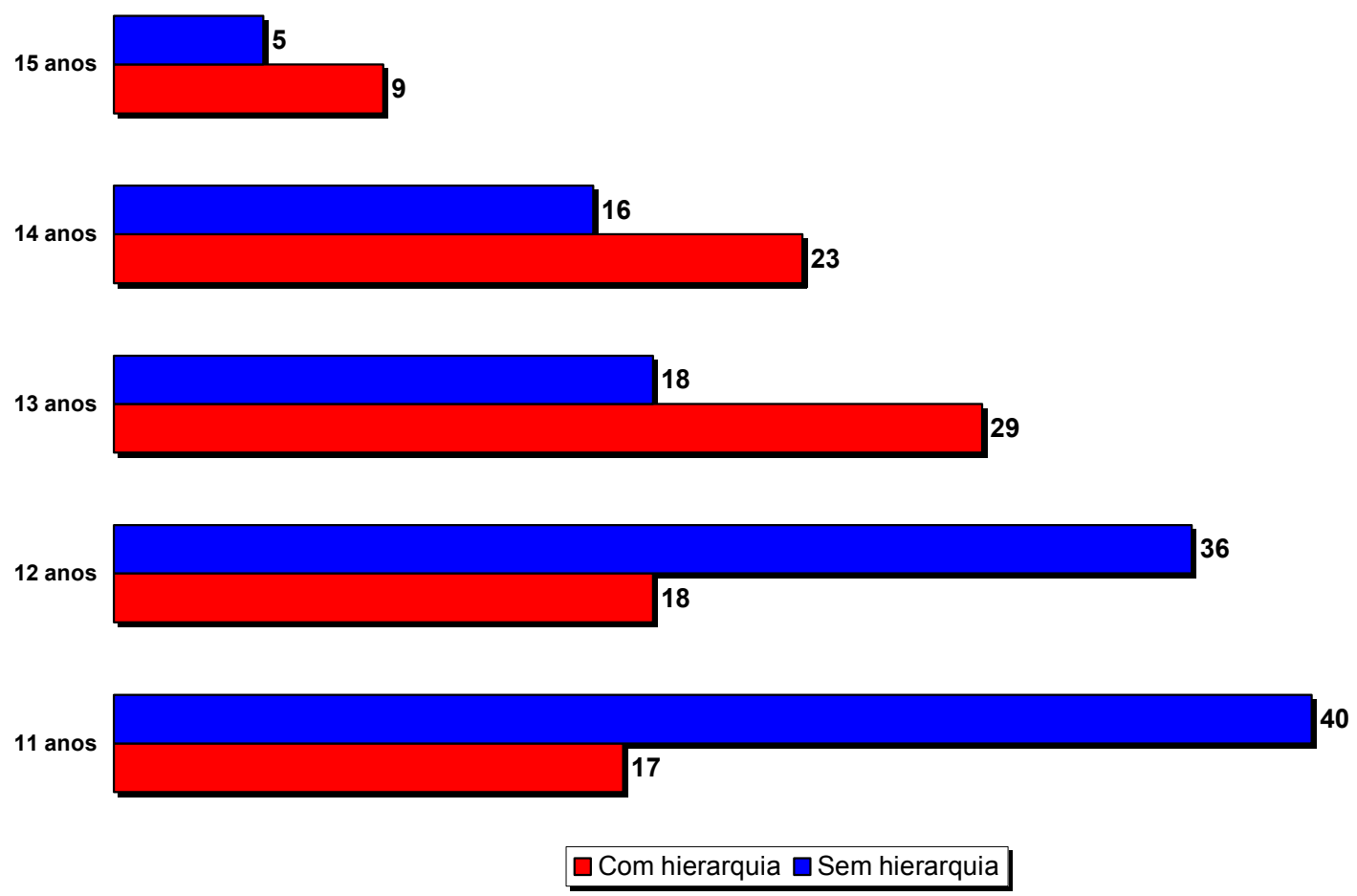

Gráfico 8

HIERARQUIZAÇÃO SEXO/FAIXA ETÁRIA

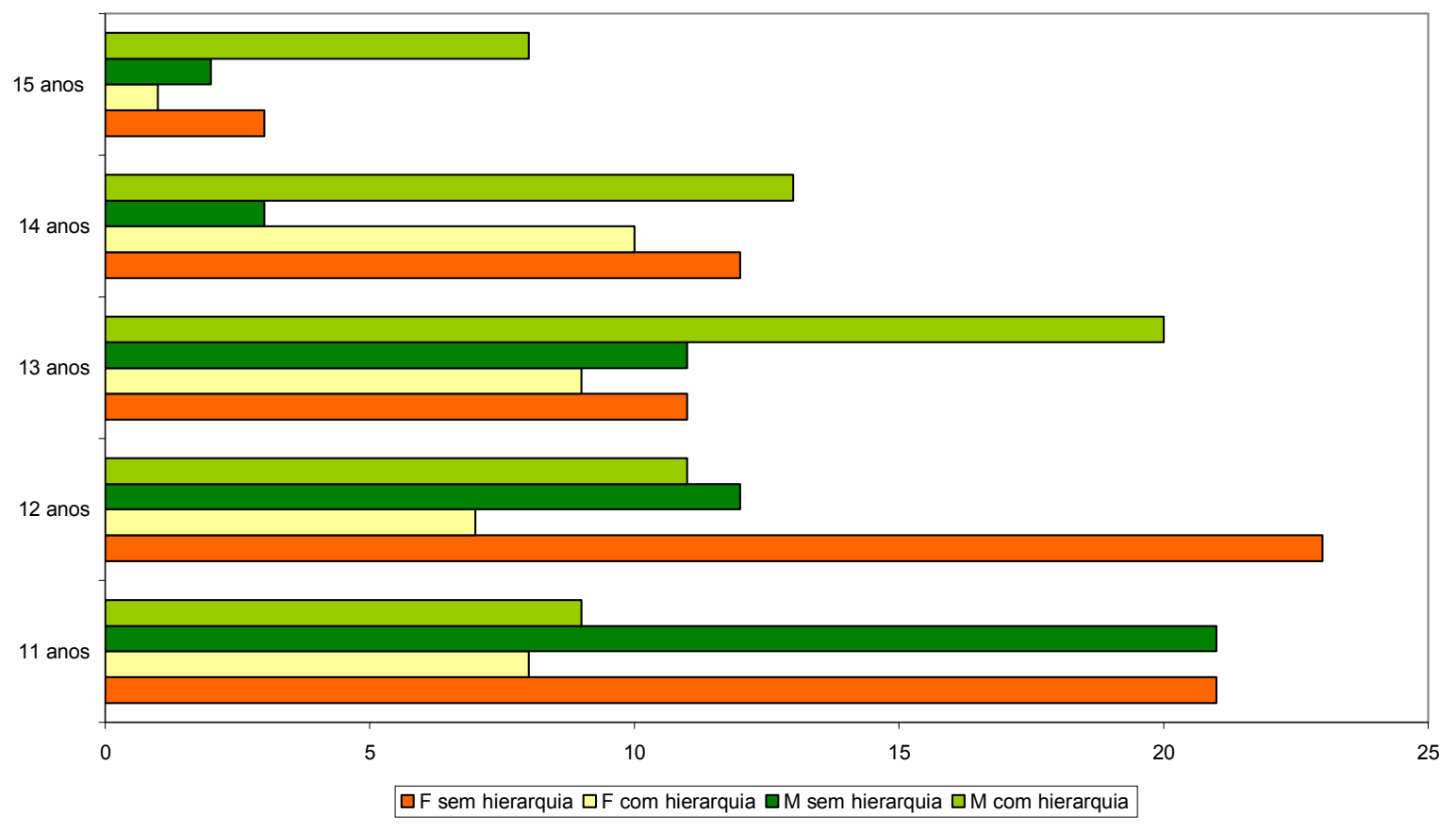




\section{Gráfico 9}

MODELOS APLICADOS POR IDADE

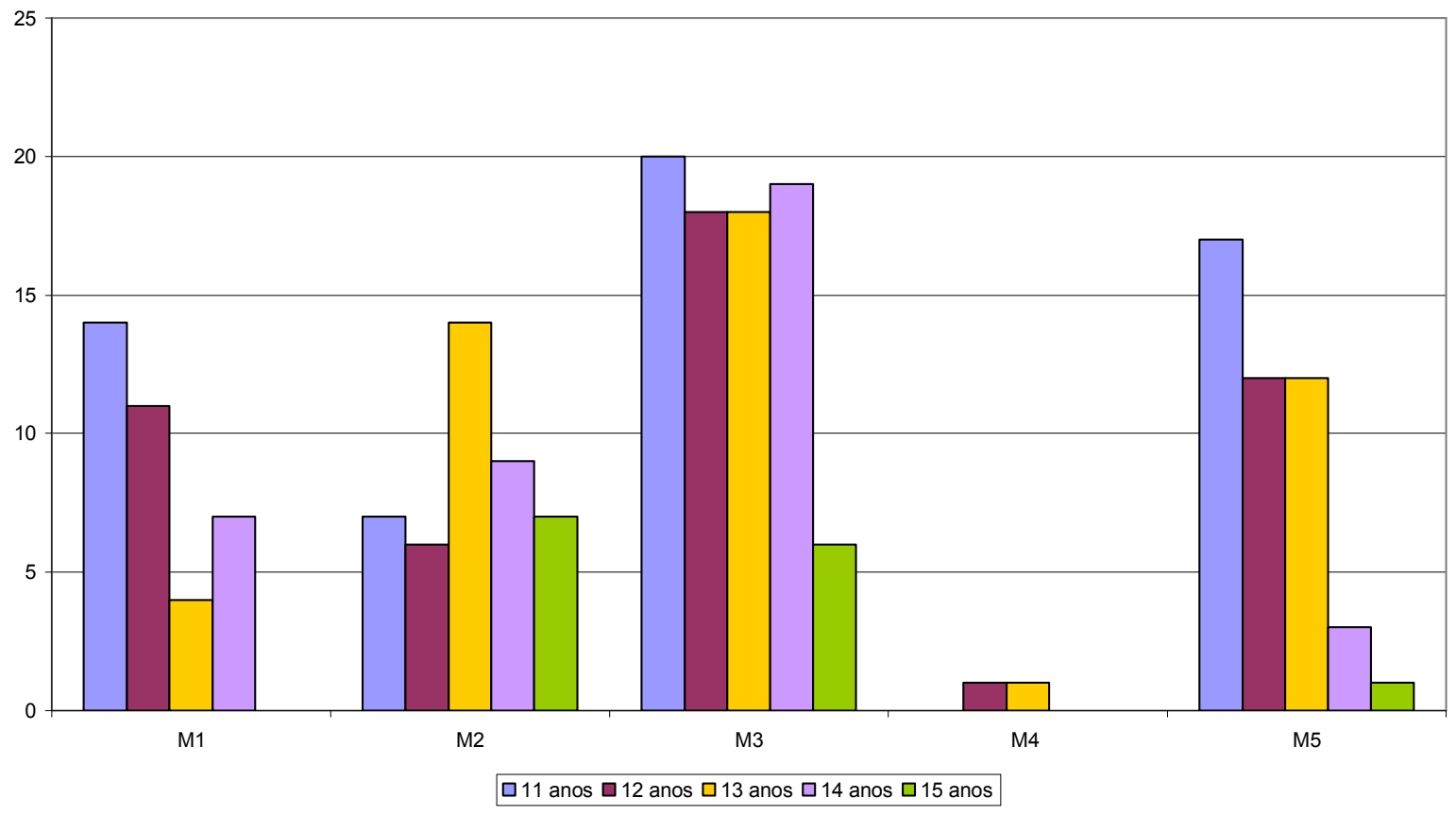

Modelo 1: Trabalho

Modelo 2: Virtude

Modelo 3: Sexo

Modelo 4: Sexualidade

Modelo 5: Gênero

\section{Gráfico 10}

MODELOS APLICADOS - 11 ANOS

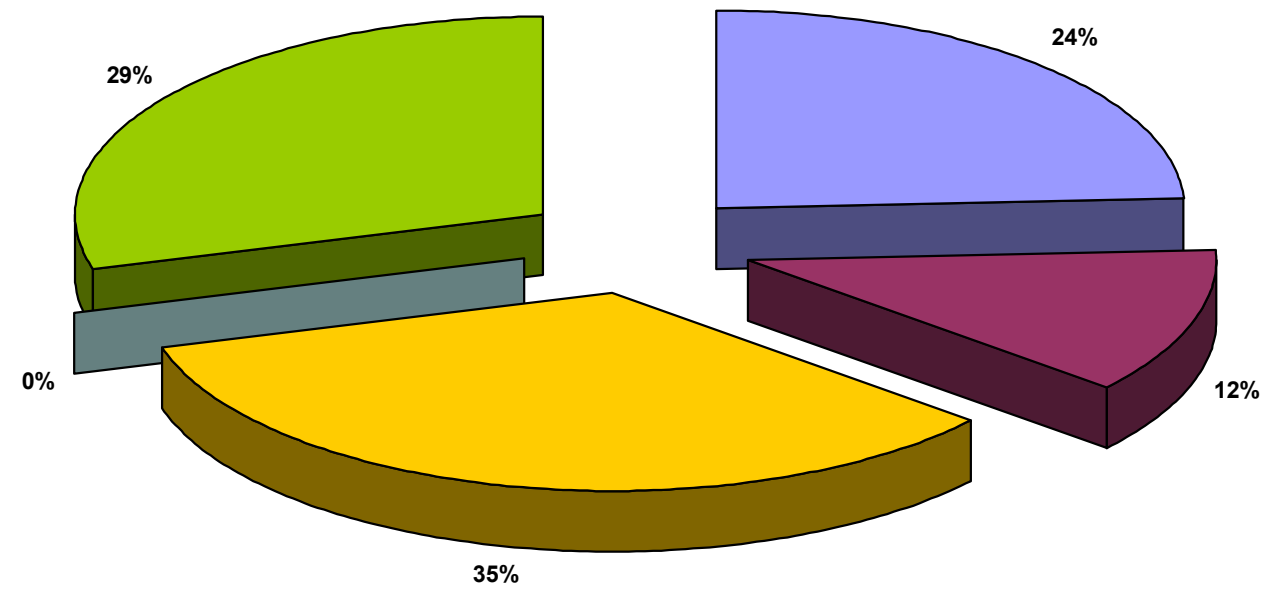




\section{Gráfico 11}

MODELOS APLICADOS - 12 ANOS

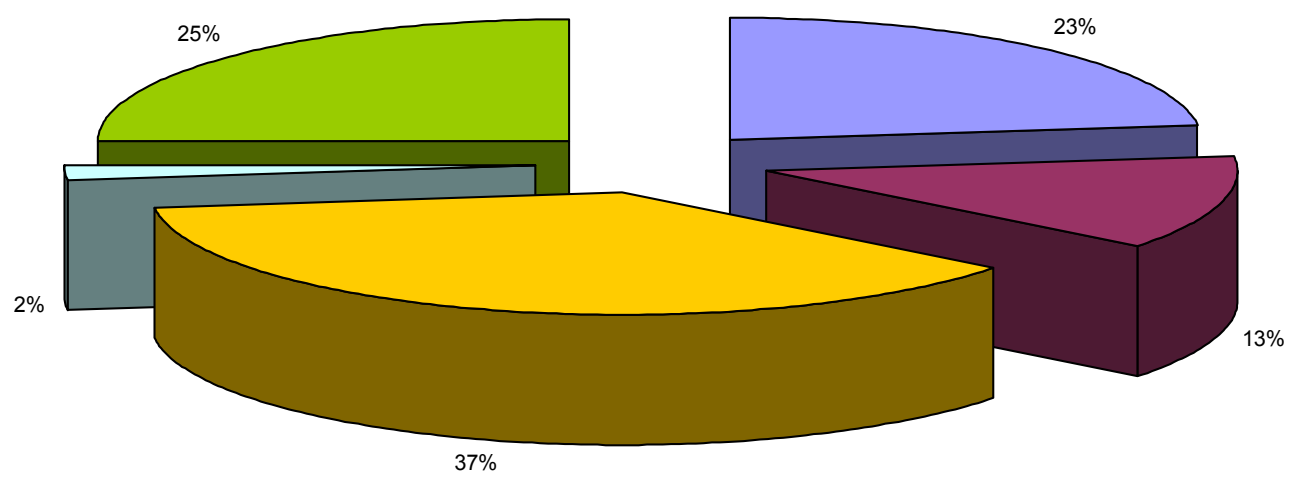

$\square \mathrm{M} 1 \mathrm{MM} 2 \square \mathrm{M} 3 \mathrm{MM} 4 \square \mathrm{M} 5$

\section{Gráfico 12}

MODELOS APLICADOS - 13 ANOS

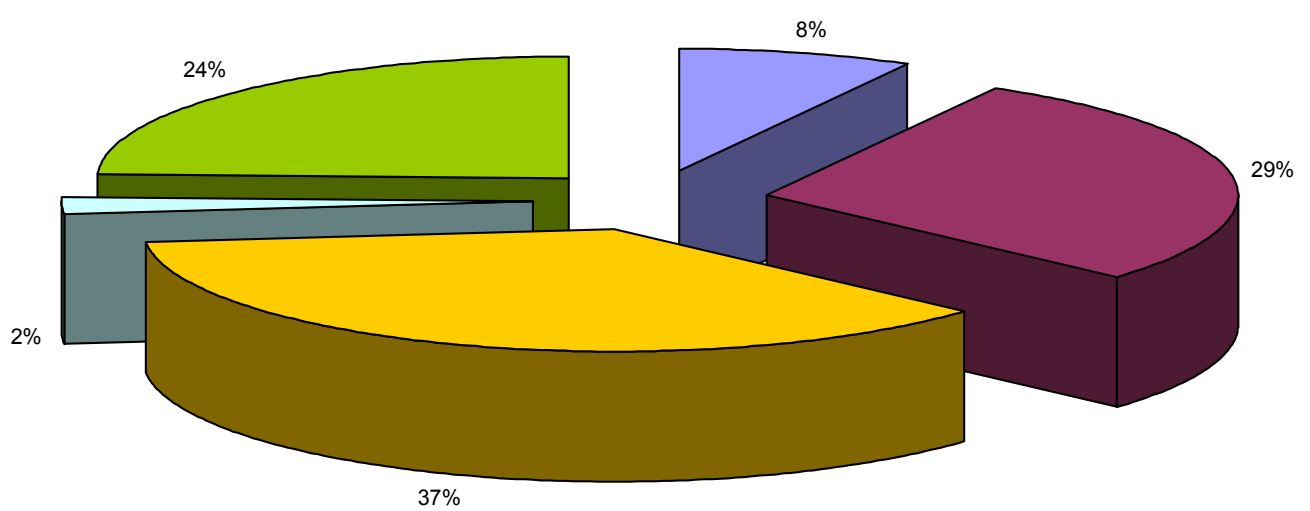

$\square \mathrm{M} 1 \square \mathrm{M} 2 \square \mathrm{M} 3 \square \mathrm{M} 4 \square \mathrm{M} 5$

Modelo 1: Trabalho
Modelo 2: Virtude

Modelo 5: Gênero 


\section{Gráfico 13}

MODELOS APLICADOS - 14 ANOS

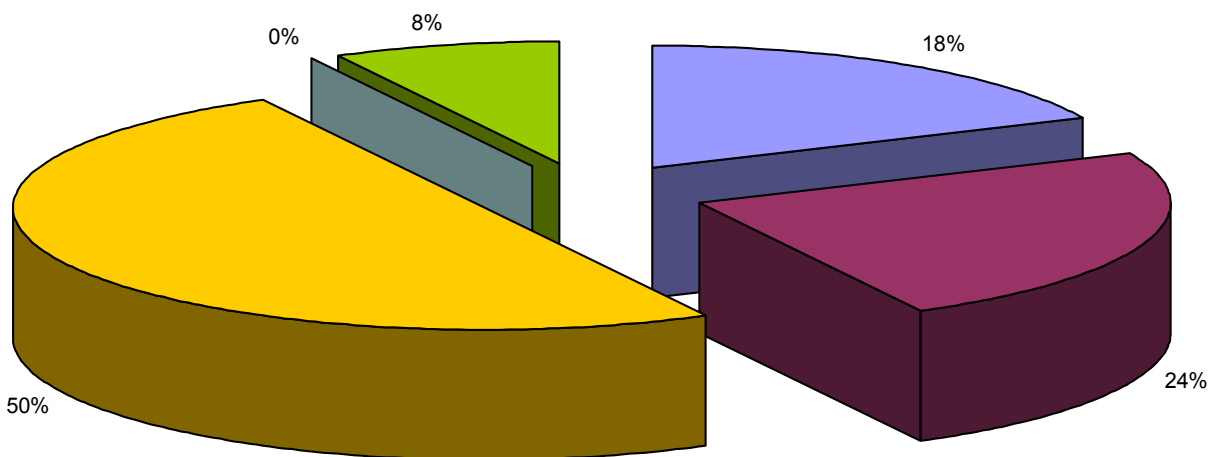

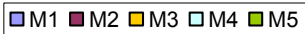

\section{Gráfico 14}

MODELOS APLICADOS - 15 ANOS
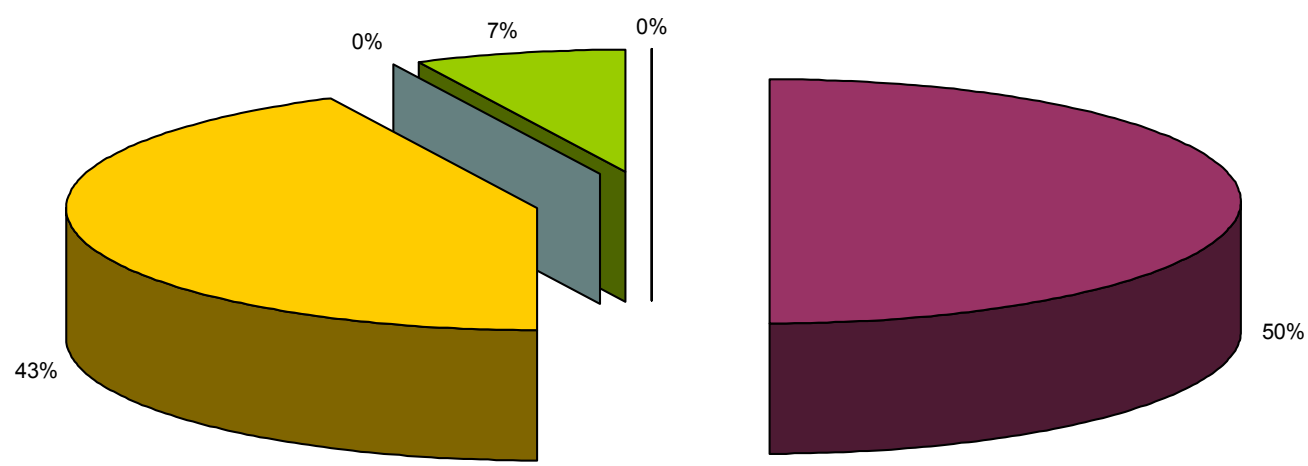

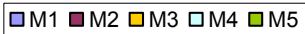

Modelo 1: Trabalho Modelo 4: Sexualidade
Modelo 2: Virtude Modelo 5: Gênero 


\section{2. C - Descrição complementar dos dados da primeira fase:}

\section{(Adjetivação hierarquizada)}

Durante a análise feita para a primeira série de questões foi paulatinamente evidenciada uma hierarquização subliminar, àquela prevista na hipótese inicial de nossa investigação.

Gradativamente surgiam demonstrações, nas afirmações feitas pelos respondentes, que nos levavam a inferir a existência de uma maneira ainda mais sutil de imputar uma certa subordinação dos atributos definidos como inerentes à legitimação dos papéis sociais de gênero.

Uma vez feita a análise central das respostas obtidas para a primeira série de questões, optamos por aprofundar nosso estudo frente àqueles sujeitos que haviam indicado uma clara sujeição dos atributos, associados às feminilidades, em relação aqueles apontados frente às masculinidades.

Dos 211 formulários, 96 deles, representando $46 \%$ do total de adolescentes participantes, foram objeto de uma segunda análise.

Para os fins da análise aprofundada das questões de 1 a 6 optamos por selecionar aqueles sujeitos que associaram esta hierarquização a algum dos valores que possam ser constituintes da moralidade humana, especialmente aqueles considerados como virtudes da excelência humana ${ }^{42}$ e que tenham sido objeto de estudos anteriores a respeito da moralidade .

Foram feitas cento e treze referências ao atributo "Coragem" claramente com conotações distintas quando direcionadas a um ou outro papel. Quando considerado um atributo masculino esteve predominantemente associada a uma qualidade tradicionalmente masculina, da valentia, da força; por outro lado quando associado à condição feminina a qualidade da coragem foi entendido com um caráter de luta para alcançar os próprios objetivos, uma mulher "guerreira" que tem força de vontade. Esta foi uma resposta predominantemente feminina.

O atributo "Respeito" obteve setenta e sete menções, sendo que 75\% destas referências, ou seja, três quartos do total das respostas, foram associadas ao papel feminino quase que em sua maioria sugerindo uma recomendação normativa, prescrevendo posturas consideradas adequadas pelos adolescentes. O respeito masculino esteve predominantemente projetado em relação aos outros enquanto o respeito feminino remetia-se ao auto-respeito.

\footnotetext{
${ }^{42}$ Conforme discussão de Andre Comte-Sponville no "Pequeno tratado das grandes virtudes".
} 
O atributo "Responsabilidade" foi mencionado quarenta e três vezes, sendo que quando inferido ao papel masculino esteve, predominantemente, ancorado em algum tipo de compromisso assumido; quando associada ao papel feminino a responsabilidade teve uma conotação mais próxima ao fato de se cuidar de alguém ou de permanecer coerente ao esperado. Outra observação relevante diz respeito à primeira associação ao papel feminino, nenhum dos respondentes fez esta associação direta.

Neste sentido propusemo-nos a aprofundar nossa reflexão analisando as respostas em que houvesse qualquer referência, explicita ou implícita, a alguma atitude respeitosa ou desrespeitosa associada tanto ao papel feminino quanto ao papel masculino. Para efeito desta análise remetemos o respeito a um direito objetivo ou subjetivo do sujeito.

Da mesma maneira interessou-nos aprofundar a análise quando da menção à "Responsabilidade" associada ou não à maturidade. Neste quesito obtivemos 43 menções nas respostas obtidas com $45 \%$ da representatividade associadas ao papel masculino, distribuídas entre as três perguntas que se remetiam ao papel masculino, enquanto foram obtidos $55 \%$ do total concentrado apenas nas segunda e terceira perguntas feitas com relação às mulheres. Não houve uma associação direta, inicial, do atributo "Responsabilidade" com o papel feminino.

\section{Exemplos de respostas:}

Atributo "Coragem". 113 menções

\section{Pergunta 1: Homem que é homem é...}

"Homem que é homem é: corajoso e galinha."

"Homem que é homem é: forte."

"Homem que é homem é: valente."

M14.5D(4.4)08

\section{Pergunta 2: Mulher que é mulher é...}

"Mulher que é mulher é: aquela que enfrenta os seus problemas de frente."

'Mulher que é mulher é: batalhadora." $\mathrm{F} 11.5 \mathrm{C}(2.3) 18$

"Mulher que é mulher é: corajosa e lutadora." $\mathrm{F} 12.6 \mathrm{~B}(6.8) 19$

\section{Pergunta 3: Homem só é homem se...}

"Homem só é homem se: não levar desaforo para casa."

$\mathrm{M} 11.6 \mathrm{~B}(3.4) 08$

"Homem só é homem se: ele tiver coragem no que faz." M13.5D(1.1)07

"Homem só é homem se: ele luta contra o mundo."

\section{Pergunta 4: Mulher só é mulher se...}

"Mulher só é mulher se: se tiver força de vontade." 
"Mulher só é mulher se: corre atrás do interesse.".

$\mathrm{M} 12.5 \mathrm{~A}(1.2) 09$

\section{Pergunta 5: Todo homem para ser homem tem que...}

“Todo homem para ser tem que: ser corajoso, macho e não estragar a natureza."

$\mathrm{M} 11.5 \mathrm{~A}(2.4) 20$

"Todo homem para ser homem tem que: ter coragem e força e tem que ter vontade de fazer sexo." $\mathrm{M} 13.5 \mathrm{~A}(3.3) 07$

"Todo homem para ser homem tem que: ser corajoso e valente." F12.6C(1.7)19

Pergunta 6: Toda mulher para ser mulher tem que...

"Toda mulher para ser mulher tem que: tem que lutar pela vida." $\mathrm{M} 11.6 \mathrm{~B}(3.4) 08$

“Toda mulher para ser mulher tem que: ser guerreira.” F13.6C(1.1)05

"Toda mulher para ser mulher tem que: tem que ser de coragem."

F11.6C(3.7)11

\begin{tabular}{|c|c|c|c|c|c|c|c|c|c|c|c|}
\hline \multicolumn{12}{|c|}{ Atributo: CORAGEM } \\
\hline \multicolumn{2}{|c|}{ Pergunta 1} & \multicolumn{2}{|c|}{ Pergunta 2} & \multicolumn{2}{|c|}{ Pergunta 3} & \multicolumn{2}{|c|}{ Pergunta 4} & \multicolumn{2}{|c|}{ Pergunta 5} & \multicolumn{2}{|c|}{ Pergunta 6} \\
\hline \multicolumn{2}{|c|}{34} & \multicolumn{2}{|c|}{16} & \multicolumn{2}{|c|}{22} & \multicolumn{2}{|c|}{15} & \multicolumn{2}{|c|}{21} & \multicolumn{2}{|c|}{05} \\
\hline $\mathrm{F}$ & $\mathrm{M}$ & $\mathrm{F}$ & $\mathrm{M}$ & $\mathrm{F}$ & $\mathrm{M}$ & $\mathrm{F}$ & $\mathrm{M}$ & $\mathrm{F}$ & $\mathrm{M}$ & $\mathrm{F}$ & $\mathrm{M}$ \\
\hline 16 & 18 & 14 & 02 & 12 & 10 & 11 & 04 & 11 & 10 & 03 & 02 \\
\hline
\end{tabular}

Atributo "Respeito" .77 menções

Pergunta 1: Homem que é homem é...

"Homem que é homem é: respeitador com as mulheres."

$\mathrm{M} 11.6 \mathrm{~B}(3.4) 08$

"Homem que é homem é: sabe respeitar o próximo e é educado."

F13.6B(3.3)05

Pergunta 2: Mulher que é mulher é...

"Mulher que é mulher é: não provoca homem."

M11.5D(4.6)20

"Mulher que é mulher é: não corre atrás de homem."

F13.7D(3.3)09

Pergunta 3: Homem só é homem se...

"Homem só é homem se: tratar as mulheres como elas merecem."

F14.8A(9.9)16

"Homem só é homem se: não bater mais na pessoa que está ao seu lado."

$\mathrm{F} 14.8 \mathrm{~A}(5.9) 16$

\section{Pergunta 4: Mulher só é mulher se...}

"Mulher só é mulher se: se der ao respeito."

"Mulher só é mulher se: se não ficar com liberdade com homem."

F12.6C(5.7)19

Pergunta 5: Todo homem para ser homem tem que... 
"Todo homem para ser homem tem que: tem que ter respeito com as mulheres, com a esposa, com a namorada, etc."

$\mathrm{M} 13.7 \mathrm{C}(2.3) 12$

"Todo homem para ser homem tem que: se respeitar a ele e as pessoas e saber honrar a si próprio e quem está ao redor dele."

$\mathrm{F} 15.6 \mathrm{~A}(1.1) 02$

“Todo homem para ser homem tem que: respeitar a mulher em todos os sentidos."

$\mathrm{M} 13.7 \mathrm{~B}(3.3) 12$

\section{Pergunta 6: Toda mulher para ser mulher tem que...}

"Toda mulher para ser mulher tem que: ter respeito com os homens e consigo mesma, ter caráter e não falar palavrão."

$\mathrm{F} 14.6 \mathrm{~A}(2.3) 03$

"Toda mulher para ser mulher tem que: respeitar o marido e os amigos do marido."

$\mathrm{F} 11.5 \mathrm{C}(2.3) 18$

"Toda mulher para ser mulher tem que: tem que se valorizar mais." $\quad \mathrm{F} 14.8 \mathrm{~B}(6.7) 16$

"Toda mulher para ser mulher tem que: tem que ter caráter de mulher e não fazer safadeza e não chifrar."

$\mathrm{F} 12.6 \mathrm{C}(5.7) 19$

"Toda mulher para ser mulher tem que: ter dignidade, ter classe, cultura, respeitar e ser respeitada e nunca perder a cabeça."

F14.8A(9.9)16

\begin{tabular}{|c|c|c|c|c|c|c|c|c|c|c|c|}
\hline \multicolumn{12}{|c|}{ Atributo: RESPEITO } \\
\hline \multicolumn{2}{|c|}{ Pergunta 1} & \multicolumn{2}{|c|}{ Pergunta 2} & \multicolumn{2}{|c|}{ Pergunta 3} & \multicolumn{2}{|c|}{ Pergunta 4} & \multicolumn{2}{|c|}{ Pergunta 5} & \multicolumn{2}{|c|}{ Pergunta 6} \\
\hline \multicolumn{2}{|c|}{2} & \multicolumn{2}{|c|}{16} & \multicolumn{2}{|c|}{7} & \multicolumn{2}{|c|}{23} & \multicolumn{2}{|c|}{11} & \multicolumn{2}{|c|}{18} \\
\hline $\mathrm{F}$ & $\mathrm{M}$ & $\mathrm{F}$ & $\mathrm{M}$ & $\mathrm{F}$ & $\mathrm{M}$ & $\mathrm{F}$ & $\mathrm{M}$ & $\mathrm{F}$ & $\mathrm{M}$ & $\mathrm{F}$ & $\mathrm{M}$ \\
\hline 2 & 0 & 6 & 10 & 4 & 3 & 16 & 7 & 6 & 5 & 13 & 5 \\
\hline
\end{tabular}

Atributo "Responsabilidade"

43 menções

Pergunta 1: Homem que é homem é...

"Homem que é homem é: não faz criancice."

F12.6C(5.7)19

"Homem que é homem é: responsável."

$\mathrm{M} 12.5 \mathrm{C}(1.5) 09$

"Homem que homem é: responsável."

F13.7A(3.3)09

Pergunta 2: Não houve incidência.

Pergunta 3: Homem só é homem se...

"Homem só é homem se: não for criança."

F15.6C(1.1)02

"Homem só é homem se: assumir suas responsabilidades."

$\mathrm{F} 12.6 \mathrm{~A}(2.4) 19$

"Homem só é homem se: tem suas responsabilidades e as cumpre."

$\mathrm{F} 11.6 \mathrm{~B}(1.3) 11$

Pergunta 4: Mulher só é mulher se... 
"Mulher só é mulher se: ela assumir os atos dela."

$\mathrm{M} 14.6 \mathrm{~B}(1.1) 02$

"Mulher só é mulher se: cumprir com os seus compromissos."

F12.6A(3.4)19

"Mulher só é mulher se: for capaz de fazer o que fala."

F13.8A(3.3)03

\section{Pergunta 5: Todo homem para ser homem tem que...}

"Todo homem para ser homem tem que: saber se virar sozinho, aprendendo a respeitar o que é do outro e acabar com o preconceito."

F14.8A(7.9)16

"Todo homem para ser homem tem que: ter responsabilidade de si mesmo e não ficar por aí brigando com ninguém."

$\mathrm{F} 11.5 \mathrm{D}(2.5) 18$

"Todo homem para ser homem tem que: largar de besteira."

F11.6C(6.7)11

Pergunta 6: Toda mulher para ser mulher tem que...

"Toda mulher para ser mulher tem que: ter caráter e respeitar os outros."

F11.6C(5.7)11

"Toda mulher para ser mulher tem que: ser primeiramente mulher de assumir seus atos e fazer o papel dela."

$\mathrm{F} 14.8 \mathrm{~B}(4.7) 16$

"Toda mulher para ser mulher tem que: ser responsável pelos seus atos e ter responsabilidade."

F13.7A(3.3)09

"Toda mulher para ser mulher tem que: tem que ser firmeza, respeitar e assumir o que faz."

M11.5D(1.6)20

\begin{tabular}{|c|c|c|c|c|c|c|c|c|c|c|c|}
\hline \multicolumn{12}{|c|}{ Atributo: RESPONSABILIDADE } \\
\hline \multicolumn{2}{|c|}{ Pergunta 1} & \multicolumn{2}{|c|}{ Pergunta 2} & \multicolumn{2}{|c|}{ Pergunta 3} & \multicolumn{2}{|c|}{ Pergunta 4} & \multicolumn{2}{|c|}{ Pergunta 5} & \multicolumn{2}{|c|}{ Pergunta 6} \\
\hline \multicolumn{2}{|c|}{7} & \multicolumn{2}{|c|}{0} & \multicolumn{2}{|c|}{10} & \multicolumn{2}{|c|}{9} & \multicolumn{2}{|c|}{4} & \multicolumn{2}{|c|}{13} \\
\hline $\mathrm{F}$ & $\mathrm{M}$ & $\mathrm{F}$ & $\mathrm{M}$ & $\mathrm{F}$ & M & $\mathrm{F}$ & M & $\mathrm{F}$ & $\mathrm{M}$ & $\mathrm{F}$ & M \\
\hline 4 & 3 & 0 & 0 & 8 & 2 & 4 & 5 & 3 & 1 & 10 & 3 \\
\hline
\end{tabular}

\section{Comentários sobre os dados obtidos}

Dados complementares

(Perguntas 1 a 6)

A tabulação das respostas nas quais encontramos o que aqui denominamos de adjetivação hierarquizada permitiu identificar algumas tendências que mereceram a nossa atenção.

Apresentamos sob a forma de gráficos as evidências de qualificações hierarquizadas no gráfico de número 15. Chamamos especial atenção para o fato do atributo "Coragem" 
surgir de maneira destacada como resposta à questão 1 que se refere à legitimação da masculinidade. A mesma tendência se apresentou nas demais perguntas associadas ao "ser" ou "ter" atitude de homem, questões 3 e 5.

Paralelamente, o atributo "Respeito" tem incidência maior nas questões associadas à legitimação social da feminilidade (questões, 2, 4 e 6).

Os gráficos de números 16 a 18 detalham a distribuição de cada um dos atributos elencados para a nossa análise complementar demonstrando o desempenho de cada adjetivação de acordo com o sexo do respondente cuja seqüência segue uma ordem decrescente em função da quantidade de menções obtidas.

\section{Gráfico 15}

COMPARATIVO ATRIBUTOS INFERIDOS

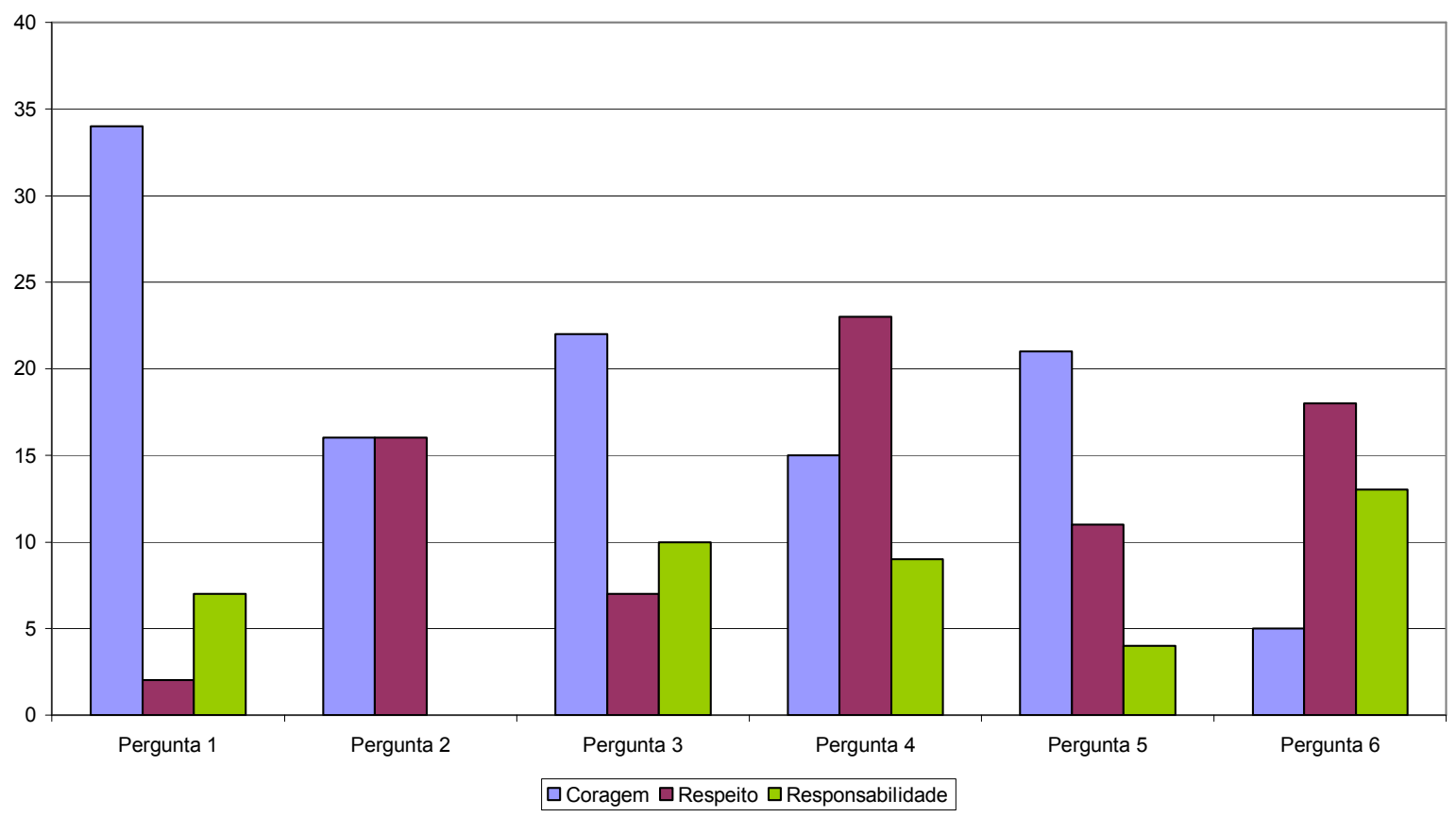


Gráfico 16

ATRIBUTO - CORAGEM

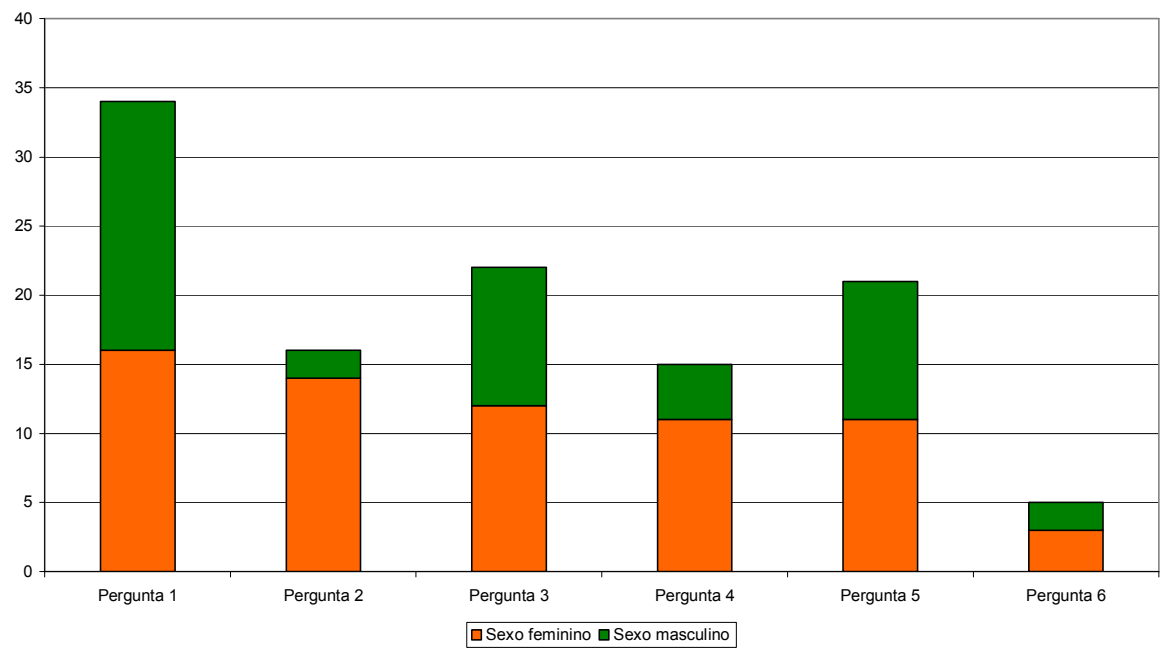

Gráfico 17

ATRIBUTO - RESPEITO

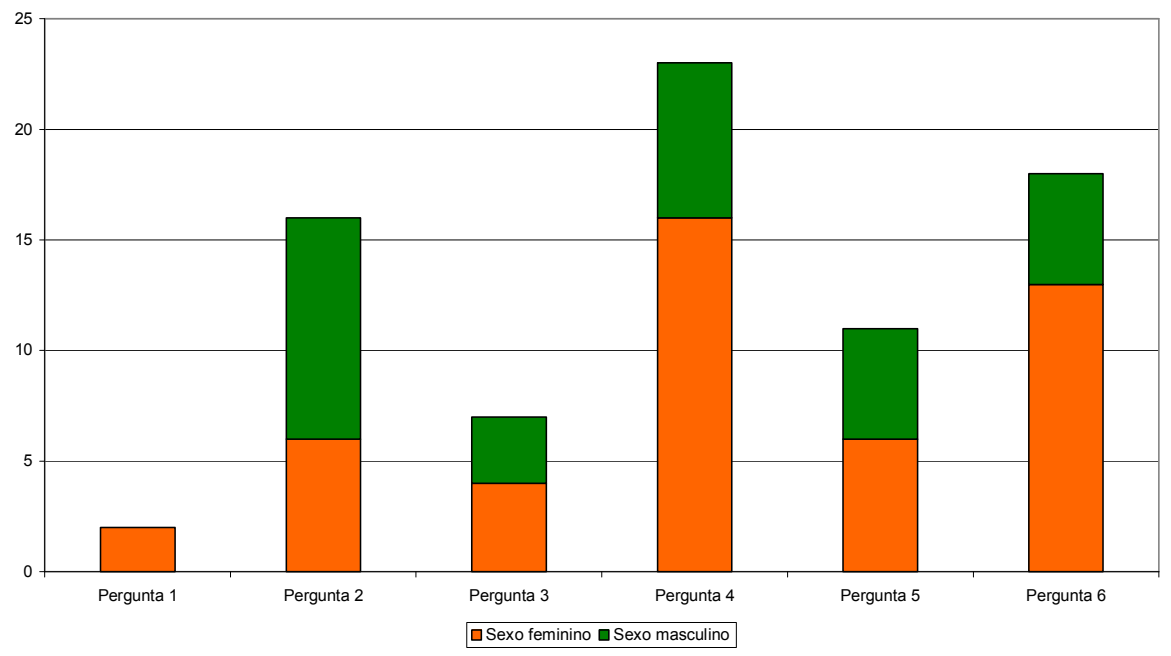

Gráfico 18

ATRIBUTO - RESPONSABILIDADE

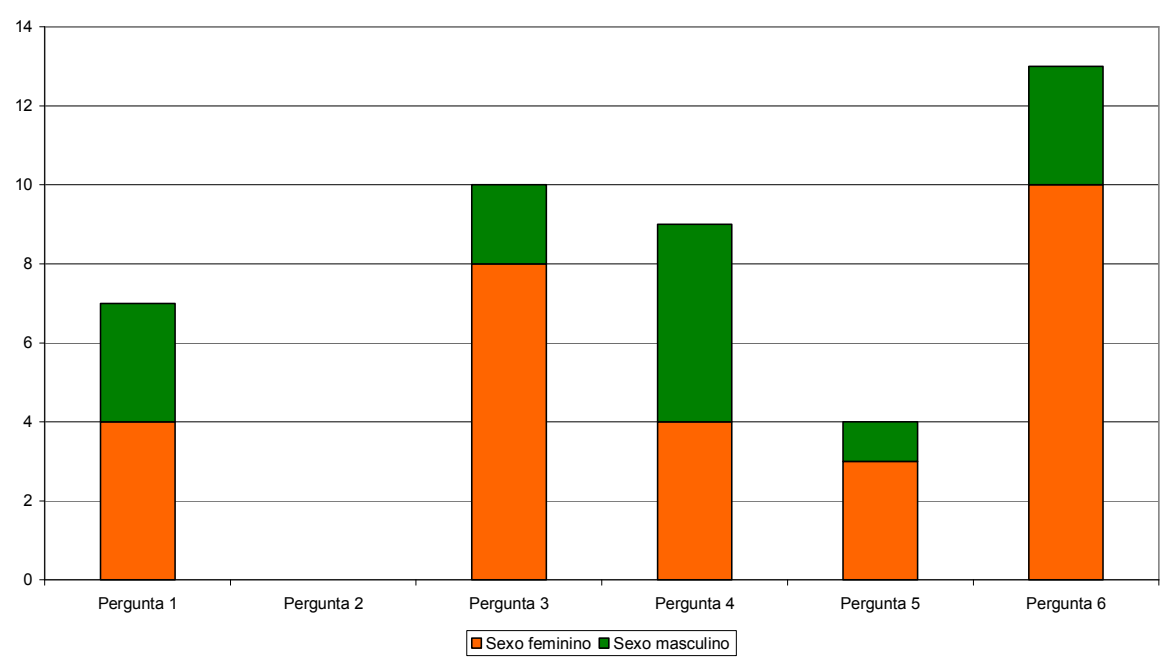




\section{2. D - Descrição dos modelos da segunda fase}

\section{Segunda fase da análise}

A análise das respostas da segunda série de questões sugeriu a existência de duas lógicas predominantes, fato este que acabou gerando a divisão das respostas em dois grupos.

O primeiro grupo de respostas foi aquele em que os respondentes, em suas afirmações, assumiram o partido de um dos envolvidos explicitando as suas inferências. O segundo grupo de respondentes foi aquele que não aplicou nenhum juízo de valor diretamente à questão proposta.

Os dois grupos, "A" e "B", tiveram por sua vez subdivisões que acabaram por gerar os modelos organizadores de pensamento 1 e 2 , e os modelos 3 e 4, respectivamente. Um último agrupamento é resultado das afirmações nas quais os adolescentes sugeriam situações que não se aplicavam diretamente à hipótese apresentada.

Pergunta 7:

"Homem quando briga com mulher é porque:

Grupo A - Com juízo de valor

\section{Modelo 1 - JUSTIFICA A AGRESSÃO}

Total geral de respostas para este modelo: 84

$40 \%$ do total

O modelo 1 das respostas obtidas agrupou todas as respostas em que os sujeitos entendiam ser a agressão justificável a partir de um evento inferido à questão proposta Um primeiro modelo de tomada de partido foi obtido a partir das respostas que justificaram a atitude do agressor a partir de alguma espécie de atitude indevida por parte da agredida. Ao conjunto das questões que seguiam este raciocínio, aplicada uma análise ainda mais detalhada foi possível subdividir o modelo 1 , nos submodelos $1 \mathrm{~A}$ - agressão motivada por traição - com $35 \%$ do total deste modelo, $1 \mathrm{~B}$ - a agressão é resultado de um problema de conduta da agredida - com $28 \%$ das respostas, $1 \mathrm{C}$ - agressão justificada por alguma espécie de decepção 
do agressor - com $24 \%$ e 1D - agressão motivada pela "legítima defesa do sentimento" do agressor - com $13 \%$.

Exemplos de respostas:

Submodelo 1A Traição

"Homem quando briga com mulher é porque: teve um motivo, descobriu que ela o traiu." F14.8A(3.9)16

"Homem quando briga com mulher é porque: a mulher traiu." M14.5D(1.4)08

"Homem quando briga com mulher é porque: ela traiu ele com outro."

$\mathrm{M} 13.5 \mathrm{~A}(3.3) 07$

"Homem quando briga com mulher é porque: ela está traindo ele com outro homem."

M13.5D(1.1)07

"Homem quando briga com mulher é porque: ela chifrou ele, e ele fica uma fera."

$\mathrm{M} 12.5 \mathrm{C}(5.5) 09$

Submodelo 1B Desqualifica a agredida

"Homem quando briga com mulher é porque: a mulher não tem valor, não tem caráter."

$\mathrm{F} 14.8 \mathrm{~B}(1.7) 16$

"Homem quando briga com mulher é porque: a mulher é muito galinha."

$\mathrm{F} 11.5 \mathrm{~B}(2.5) 18$

"Homem quando briga com mulher é porque: ele não se agüenta mais com as coisas erradas que ela faz e acaba batendo e machucando a mulher."

M12.6C(3.3)13

"Homem quando briga com mulher é porque: quer corrigir o seu erro."

$\mathrm{M} 12.6 \mathrm{~B}(3.5) 13$

"Homem quando briga com mulher é porque: ela desrespeitou ele na frente de outro homem."

$13.6 \mathrm{~A}(1.3) 08$

Submodelo 1C Decepção/Provocação

"Homem quando briga com mulher é porque: o homem quer que a mulher faça alguma coisa para ele e ela não quer."

$\mathrm{M} 12.6 \mathrm{C}(2.3) 13$

"Homem quando briga com mulher é porque: ela fica só na rua e não sai vai atrás de emprego."

M13.6C(3.4)08

"Homem quando briga com mulher é porque: ela sai e não dá explicação."

$\mathrm{F} 14.8 \mathrm{~B}(5.7) 16$

"Homem quando briga com mulher é porque: por causa da televisão, ele está vendo o jogo e ela fica querendo ver a novela."

M11.5B(1.5)20 
"Homem quando briga com mulher é porque: a mulher fica enchendo o saco só porque o homem quer sair para se divertir e ela fica reclamando."

$\mathrm{M} 13.5 \mathrm{C}(1.2) 07$

Submodelo 1D .Legítima defesa do sentimento do agressor

"Homem quando briga com mulher é porque: ele ama ela."

$\mathrm{M} 13.7 \mathrm{C}(2.3) 12$

"Homem quando briga com mulher é porque: tem amor por ela."

$\mathrm{F} 11.5 \mathrm{~B}(1.5) 18$

"Homem quando briga com mulher é porque: ele gosta dela."

$\mathrm{M} 12.6 \mathrm{~B}(4.5) 13$

\begin{tabular}{|c|c|c|c|c|c|c|c|}
\hline \multicolumn{2}{|c|}{ Submodelo 1A } & \multicolumn{2}{c|}{ Submodelo 1B } & \multicolumn{2}{c|}{ Submodelo 1C } & \multicolumn{2}{c|}{ Submodelo 1D } \\
\hline \multicolumn{2}{|c|}{29} & \multicolumn{2}{|c|}{24} & \multicolumn{2}{|c|}{20} & \multicolumn{2}{c|}{11} \\
\hline $\mathrm{F}$ & $\mathrm{M}$ & $\mathrm{F}$ & $\mathrm{M}$ & $\mathrm{F}$ & $\mathrm{M}$ & $\mathrm{F}$ & $\mathrm{M}$ \\
\hline 9 & 20 & 12 & 12 & 5 & 15 & 3 & 8 \\
\hline
\end{tabular}

Submodelo 2 - RECRIMINA A AGRESSÃO

Total geral de respostas para este modelo: 62

$30 \%$ do total

O modelo 2 das respostas obtidas é o resultado do agrupamento das respostas em que os sujeitos entenderam que o desentendimento não é justificável e atribuem alguma espécie de responsabilidade ao agressor. Para esta forma de interpretar a questão proposta encontramos duas maneiras predominantes de julgar a hipótese apresentada. O primeiro grupo, submodelo 2A, responsabiliza o agressor, do sexo masculino, pela contenda atribuindo a situação a um abuso das prerrogativas do papel masculino. O segundo grupo, submodelo $2 \mathrm{~B}$, por sua vez interpretou a situação como resultado da falta de habilidade, ou incompetência emocional, do agressor. O submodelo $2 \mathrm{~A}$ representou $90 \%$ do total de respostas obtidas enquanto o submodelo 2 B representou $10 \%$ deste modelo.

Exemplos de respostas:

Submodelo 2A Desqualifica o agressor

"Homem quando briga com mulher é porque: ele é muito sem vergonha porque brigar com uma mulher é covardia."

F11.6C(7.7) 11

"Homem quando briga com mulher é porque: quer ser autoritário, por querer mandar na mulher, por ser um idiota."

$\mathrm{F} 12.6 \mathrm{~B}(6.8) 19$

"Homem quando briga com mulher é porque: ele é um covarde porque não pode agredir uma mulher."

$\mathrm{F} 11.5 \mathrm{D}(2.5) 18$

"Homem quando briga com mulher é porque: é covarde não tem coragem de brigar com homem."

F12.6A(2.4)19 
"Homem quando briga com mulher é porque: é covarde, não é homem de verdade, não honra as calças que veste."

F15.6A(1.1)02

Submodelo 2B Inabilidade emocional

"Homem quando briga com mulher é porque: ele não sabe conversar como homem e ai fica querendo resolver as coisas à força."

F11 .5C(1.3)18

"Homem quando briga com mulher é porque: não sabe amar, não reconhece nada na vida, briga por qualquer bobeira."

F13.6C(1.1)05

"Homem quando briga com mulher é porque: não a entende."

M11.5D(1.6)20

"Homem quando briga com mulher é porque: ele é muito possessivo." F13.7A(1.3)09

"Homem quando briga com mulher é porque: não agüenta levar lição de moral de uma mulher mesmo quando sabe que está errado."

F14.8A(9.9)16

Submodelo 2C Recriminação "moral"

OBS: Não houve incidência desta lógica nas afirmações feitas para esta questão.

\begin{tabular}{|c|c|c|c|c|c|}
\hline \multicolumn{2}{|c|}{ Submodelo 2A } & \multicolumn{2}{c|}{ Submodelo 2B } & \multicolumn{2}{c|}{ Submodelo 2C } \\
\hline \multicolumn{2}{|c|}{56} & \multicolumn{2}{|c|}{6} & $\mathrm{~F}$ & $\mathrm{M}$ \\
\hline $\mathrm{F}$ & $\mathrm{M}$ & $\mathrm{F}$ & $\mathrm{M}$ & 0 & 0 \\
\hline 38 & 18 & 5 & 1 & 0 \\
\hline
\end{tabular}

Grupo B - Sem juízo de valor

Este grupo reúne as respostas dos sujeitos que não deram indícios de terem atribuído a responsabilidade do conflito a nenhum dos personagens envolvidos, preferindo entendê-los como de responsabilidade de ambos ou inferindo que a situação como inerente ao próprio convívio entre os personagens.

\section{Modelo 3 - AGRESSÃO MOTIVADA POR SENTIMENTO}

Total geral de respostas para este modelo: 46

$21 \%$ do total

Para o modelo 3 fizemos um agrupamento das respostas em que se atribui o conflito a algum tipo de sentimento. $\mathrm{O}$ primeiro submodelo $3 \mathrm{~A}$ foi aquele em que os respondentes atribuíram o problema ao ciúme sem explicitar se o sentimento tivera origem no agressor ou na agredida representando $46 \%$ das afirmações obtidas neste modelo. O submodelo $3 \mathrm{~B}$ reuniu 
aquelas respostas que se remeteram a um sentimento, quer fosse pela sua presença ou pela sua ausência atribuído a qualquer dos personagens, com um total de 54\% deste item.

Exemplos de respostas:

Submodelo 3A Ciúme/Desconfiança

"Homem quando briga com mulher é porque: ciúme dos dois lados." $\quad \mathrm{F} 15.8 \mathrm{~B}(1.2) 02$

"Homem quando briga com mulher é porque: há muito ciúme." $\quad$ F14.8A(6.9)16

"Homem quando briga com mulher é porque: a maioria das vezes é por ciúme mesmo e também brigam por besteira."

F14.8A(1.9)16

"Homem quando briga com homem é porque: sentem muito ciúme um do outro."

F13.7C(1.2)09

"Homem quando briga com homem é porque: têm ciúmes demais porque se amam."

$\mathrm{F} 12.7 \mathrm{C}(1.1) 03$

Submodelo 3B Final de relacionamento

"Homem quando briga com mulher é porque: não está mais dando certo, o amor acabou."

$\mathrm{F} 11.5 \mathrm{~B}(3.5) 18$

"Homem quando briga com mulher é porque: não tem mais amor."

$\mathrm{M} 12.5 \mathrm{C}(2.5) 09$

"Homem quando briga com mulher é porque: ele não quer mais saber da mulher."

$\mathrm{F} 11.5 \mathrm{~A}(2.5) 18$

"Homem quando briga com mulher é porque: depende, se forem casados estão naquela fase de discussão, incompreensão... de traição... acabou."

F13.7C(2.2)09

"Homem quando briga com mulher é porque: eles não estão se entendendo mais em nenhum sentido."

$\mathrm{F} 14.8 \mathrm{~B}(4.7) 16$

Submodelo 3C Inerente à convivência

OBS: Não houve incidência desta lógica nas afirmações feitas para esta questão.

\begin{tabular}{|c|c|c|c|c|c|}
\hline \multicolumn{2}{|c|}{ Submodelo 3A } & \multicolumn{2}{c|}{ Submodelo 3B } & \multicolumn{2}{c|}{ Submodelo 3C } \\
\hline \multicolumn{2}{|c|}{21} & \multicolumn{2}{|c|}{25} & F & M \\
\hline F & M & F & M & 0 & 0 \\
\hline 14 & 7 & 11 & 14 & 0 \\
\hline
\end{tabular}

\section{Modelo 4 - AGRESSÃO MOTIVADA POR CONDUTA}

Total geral de respostas para este modelo: 13

O modelo 4 foi o resultado do agrupamento das respostas obtidas em que predominou a responsabilização pelo conflito a algum aspecto relacionado à conduta. 
O submodelo 4A referiu-se a algum tipo de vício com $70 \%$ das respostas. O submodelo $4 \mathrm{~B}$ fez um associação com problemas de origem financeira representando $15 \%$ do total, a mesma representatividade obteve o submodelo $4 \mathrm{C}$ em que a conduta identificada como causadora do conflito foi a falta de respeito.

Exemplos de respostas:

Submodelo 4A Vício

"Homem quando briga com mulher é porque: pela cachaça." F14.7A(1.1)03

"Homem quando briga com mulher é porque: bebeu demais." $\mathrm{F} 11.5 \mathrm{~A}(3.5) 18$

"Homem quando briga com mulher é porque: bebeu no bar e chegou em casa bêbado."

$\mathrm{M} 14.8 \mathrm{~B}(2.2) 04$

"Homem quando briga com mulher é porque: ele bebe muito e chega em casa bêbado."

$\mathrm{M} 13.5 \mathrm{C}(2.2) 07$

"Homem quando briga com mulher é porque: está bêbado ou drogado."

$\mathrm{M} 11.5 \mathrm{C}(5.5) 20$

Submodelo 4B Problemas financeiros

"Homem quando briga com mulher é porque: tem dinheiro na conversa."

$\mathrm{M} 13.5 \mathrm{~A}(1.3) 07$

"Homem quando briga com mulher é porque: tem problemas financeiros."

$\mathrm{F} 11.5 \mathrm{~A}(1.5) 18$

Submodelo 4C Falta de respeito/postura

"Homem quando briga com mulher é porque: eles não se respeitam, o homem trai a mulher, a mulher trai o homem."

$\mathrm{M} 11.6 \mathrm{~A}(3.3) 08$

"Homem quando briga com mulher é porque: eles não se respeitam a si mesmos."

M11.5D(5.6)20

Submodelo 4D Maledicência

OBS: Não houve incidência desta lógica nas afirmações feitas para esta questão.

\begin{tabular}{|c|c|c|c|c|c|c|c|}
\hline \multicolumn{2}{|c|}{ Submodelo 4A } & \multicolumn{2}{c|}{ Submodelo 4B } & \multicolumn{2}{c|}{ Submodelo 4C } & \multicolumn{2}{c|}{ Submodelo 4D } \\
\hline \multicolumn{2}{|c|}{9} & \multicolumn{2}{|c|}{2} & \multicolumn{2}{|c|}{2} & \multicolumn{2}{c|}{0} \\
\hline $\mathrm{F}$ & $\mathrm{M}$ & $\mathrm{F}$ & $\mathrm{M}$ & $\mathrm{F}$ & $\mathrm{M}$ & $\mathrm{F}$ & $\mathrm{M}$ \\
\hline 4 & 5 & 1 & 1 & 0 & 2 & 0 & 0 \\
\hline
\end{tabular}

\section{Outros}


Motivações diversas.

Total geral de respostas nesta condição: $6 \quad 3 \%$ do total

Exemplos de respostas:

"Homem quando briga com mulher é porque: o homem não está dando conta."

$\mathrm{M} 15.8 \mathrm{~B}(3.3) 06$

"Homem quando briga com mulher é porque: ela tem algo para falar."

M15.8A(3.3)06

"Homem quando briga com mulher é porque: não tem nada." $\quad$ F14.8A(7.9)16

\begin{tabular}{|c|c|}
\hline \multicolumn{2}{|c|}{ Outros } \\
\hline \multicolumn{2}{|c|}{6} \\
\hline F & M \\
\hline 3 & 3 \\
\hline
\end{tabular}

\section{Comentários sobre os dados obtidos}

Questão 7

De maneira a facilitar a visualização da representatividade das afirmações feitas pelos adolescentes, diante da proposição de um conflito entre um homem e uma mulher, na qual o agente promotor do embate teria sido o homem, de acordo com a hipótese que lhes foi apresentada no instrumento aplicado, foram preparados os gráficos 19 e 20.

O gráfico 19 apresenta a tendência geral dos resultados sem detalhar aspectos internos à distribuição interna da representatividade relativa em cada um dos submodelos encontrados dentro da lógica aplicada; o gráfico 20 premia a distribuição dos submodelos de acordo com o sexo dos adolescentes respondentes. 


\section{Gráfico 19}

MODELOS APLICADOS

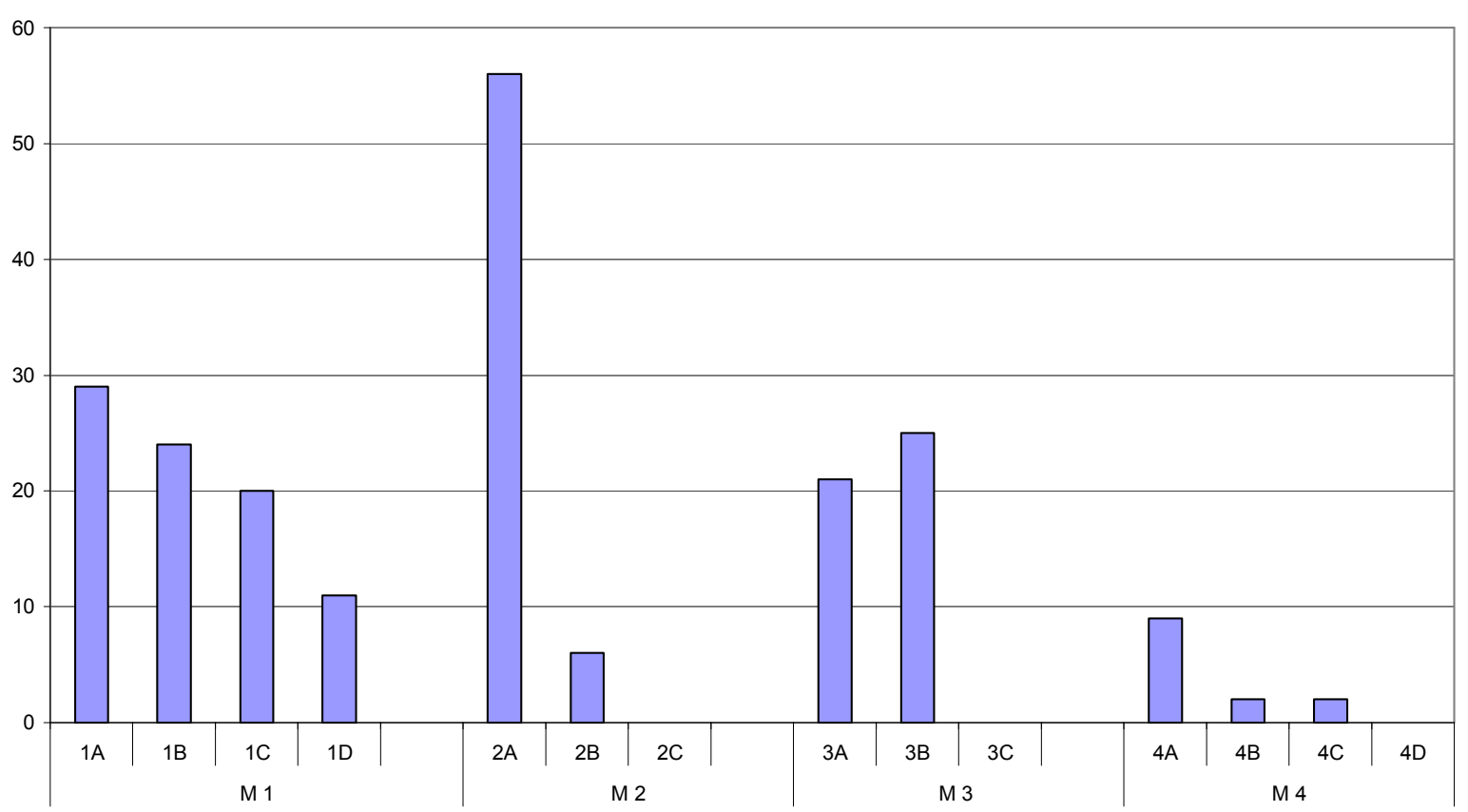

Gráfico 20

MODELOS APLICADOS POR SEXO

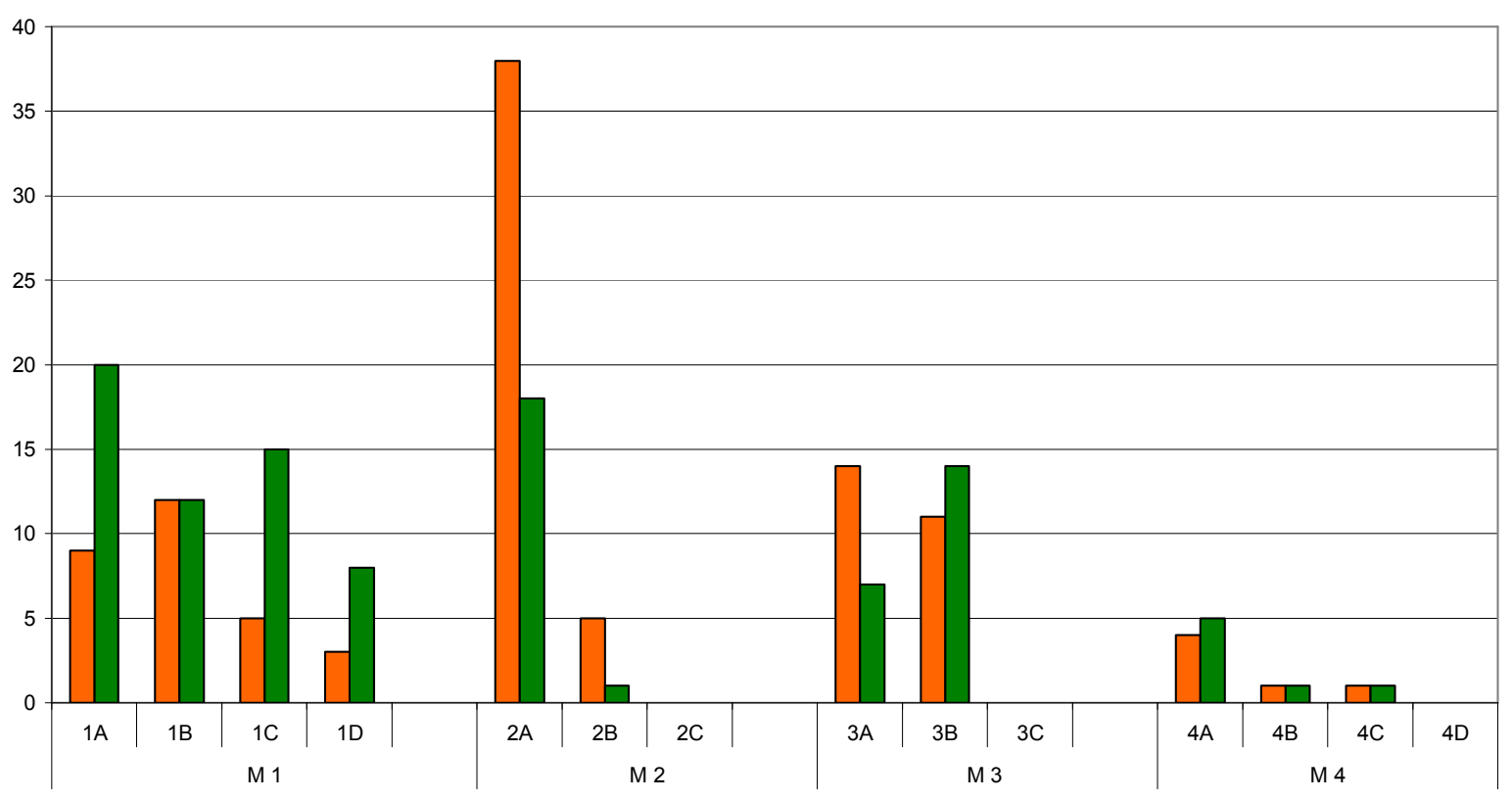

$\square$ Sexo feminino $\square$ Sexo masculino 
Os dados obtidos apontam para a predominância do modelo 2, "Recrimina a agressão" quando do embate entre um homem e uma mulher pautado especialmente em desqualificar o agredido (submodelo 2A) atribuindo, portanto ao personagem "mulher" a responsabilização pelo embate, fenômeno significativamente influenciado pelas respostas das adolescentes do sexo feminino.

Pergunta 8:

"Mulher quando briga com homem é porque:

Grupo A - Com Juízo de Valor

Modelo 1 - JUSTIFICA A AGRESSÃO

Total geral de respostas para este modelo: 93

$44 \%$ do total

O modelo 1 das respostas obtidas para a resposta 8 também foi o resultado do agrupamento das respostas cujos sujeitos interpretaram que a agressão seria justificável a partir de um evento inferido à questão proposta indicando que tais sujeitos haviam tomado o partido do agente provocador do conflito. Um primeiro sub-modelo dentro deste grupo foi obtido a partir de respostas que interpretaram o conflito como tendo sido motivado por traição, sub-modelo $1 \mathrm{~A}$, com $40 \%$ do total deste modelo. O segundo sub-modelo, 1B, é aquele em que os respondentes associaram o conflito a um problema gerado pelo agredido, causando indignação no agressor, perfazendo $8 \%$ do total deste grupo. O sub-modelo $1 \mathrm{C}$ é aquele em que os sujeitos entenderam ter sido o conflito gerado por uma decepção causada pelo agredido à agressora representando $48 \%$ do modelo 1 . O sub-modelo $1 \mathrm{D}$ que obteve $4 \%$ de respostas interpretou o conflito como sendo motivado por uma espécie de revide da agressora.

Exemplos de respostas:

Submodelo 1A Traição

"Mulher quando briga com homem é porque: virou chifruda." $\mathrm{M} 12.6 \mathrm{~B}(5.5) 13$

"Mulher quando briga com homem é porque: chegou em casa tarde todo sujo de batom." M11.5C(5.5)20

"Mulher quando briga com homem é porque: infidelidade e desrespeito dele." 
"Mulher quando briga com homem é porque: ele traiu ela com outra e é por isso que ela briga com o homem."

$\mathrm{M} 12.6 \mathrm{C}(3.3) 13$

"Mulher quando briga com homem é porque: ele chifrou ela com uma amiga ou uma parente."

$\mathrm{F} 15.6 \mathrm{C}(1.1) 02$

Submodelo 1B Desqualifica o agredido

"Mulher quando briga com homem é porque: ele é muito cara-de-pau." F12.6A(2.4)19

"Mulher quando briga com homem é porque: ele é muito safado e só quer se aproveitar."

F13.5A(1.1)03

"Mulher quando briga com homem é porque: porque o homem nunca faz o que deve."

M12.7D(1.1)03

"Mulher quando briga com homem é porque: ele quer dar uma de gostosão, de bonitão, ficar com ela e ficar com outra também."

$\mathrm{F} 14.8 \mathrm{~B}(2.7) 16$

"Mulher quando briga com homem é porque: ele é folgado."

F12.6A(1.4)19

Submodelo 1C Decepção/Provocação

"Mulher quando briga com homem é porque: tem algum motivo porque todo homem traz insegurança para uma mulher."

$\mathrm{F} 14.8 \mathrm{~A}(8.9) 16$

"Mulher quando briga com homem é porque: já não agüenta mais as coisas que ele aprontou e quer discutir a relação, mas nunca dá para ter uma 'DR' sem brigar."

F14.8A.(9.9)16

"Mulher quando briga com homem é porque: ele fez alguma coisa que a magoou."

$\mathrm{F} 14.7 \mathrm{C}(1.1) 03$

"Mulher quando briga com homem é porque: ela está com raiva do que ele fez mas eu acho que nem o homem nem a mulher deveriam brigar por qualquer coisa." $\quad \mathrm{F} 11.5 \mathrm{C}(1.3) 18$

"Mulher quando briga com homem é porque: o homem chegou em casa muito tarde."

$\operatorname{M13.7D(3.3)12}$

Submodelo 1D

Revide/Vingança

"Mulher quando briga com homem é porque: ele aprontou alguma e a mulher também faz alguma coisa para ele."

$\mathrm{F} 11.5 \mathrm{D}(4.5) 18$

"Mulher quando briga com homem é porque: ele brigou com ela e a mulher também briga."

M11.5B(3.5)20

\begin{tabular}{|c|c|c|c|c|c|c|c|}
\hline \multicolumn{2}{|c|}{ Submodelo 1 A } & \multicolumn{2}{|c|}{ Submodelo 1 B } & \multicolumn{2}{c|}{ Submodelo 1 C } & \multicolumn{2}{c|}{ Submodelo 1 D } \\
\hline \multicolumn{2}{|c|}{37} & \multicolumn{2}{|c|}{7} & \multicolumn{2}{c|}{45} & \multicolumn{2}{c|}{4} \\
\hline F & M & F & M & F & M & F & M \\
\hline
\end{tabular}




\begin{tabular}{|l|l|l|l|l|l|l|l|}
\hline 13 & 24 & 5 & 2 & 24 & 21 & 3 & 1 \\
\hline
\end{tabular}

Modelo 2 - RECRIMINA A AGRESSORA

Total geral de respostas para este modelo: 25

$12 \%$ do total

O modelo 2 das respostas obtidas é o resultado do agrupamento das respostas em que os sujeitos entenderam que o desentendimento gerado é de responsabilidade da agressora. Para esta forma de interpretar a questão proposta encontramos duas maneiras predominantes de julgar a hipótese apresentada. O primeiro grupo, submodelo $2 \mathrm{~A}$, responsabiliza a agressora, do sexo feminino, questionando a sua conduta e perfez $80 \%$ das respostas obtidas para este modelo. O segundo grupo, submodelo $2 \mathrm{~B}$, por sua vez, interpretou a situação como sendo resultado da falta de diálogo, atribuindo a responsabilidade à agressora e representou $20 \%$ deste modelo.

Exemplos de respostas:

Submodelo 2A Desqualifica a agressora

"Mulher quando briga com homem é porque: ela é uma rapariga, galinha, etc."

$\mathrm{F} 13.7 \mathrm{D}(2.3) 09$

"Mulher quando briga com homem é porque: é muito rabugenta."

$\mathrm{F} 13.6 \mathrm{~B}(2.3) 05$

"Mulher quando briga com homem é porque: não se dá ao respeito, não se porta adequadamente."

$\mathrm{F} 15.6 \mathrm{~A}(1.1) 02$

"Mulher quando briga com homem é porque: é barraqueira."

$\mathrm{F} 12.6 \mathrm{~B}(4.8) 19$

"Homem quando briga com mulher é porque: é agressiva, mal educada, ignorante."

M14.6B(1.1)02

Submodelo 2B Inabilidade emocional

"Mulher quando briga com homem é porque: não sabe conversar." $\quad \mathrm{M} 14.5 \mathrm{C}(2.2) 08$

"Mulher quando briga com homem é porque: só ela quer ter razão." M14.8A(1.2)04

Submodelo $2 \mathrm{C}$ Recriminação "moral"

OBS: Não houve incidência desta lógica nas afirmações feitas para esta questão.

\begin{tabular}{|c|c|c|c|c|c|}
\hline \multicolumn{2}{|c|}{ Submodelo 2A } & \multicolumn{2}{c|}{ Submodelo 2B } & \multicolumn{2}{c|}{ Submodelo 2C } \\
\hline \multicolumn{2}{|c|}{20} & \multicolumn{2}{|c|}{5} & $\mathrm{~F}$ & $\mathrm{M}$ \\
\hline $\mathrm{F}$ & $\mathrm{M}$ & $\mathrm{F}$ & $\mathrm{M}$ & 0 & 0 \\
\hline 13 & 7 & 0 & 5 & \\
\hline
\end{tabular}


Este grupo reúne as respostas dos sujeitos cujas respostas não explicitaram, diretamente, assumir uma posição clara de defesa dos interesses de qualquer dos envolvidos.

\section{Modelo 3 - AGRESSÃO MOTIVADA POR SENTIMENTO}

Total geral de respostas para este modelo: 71

$34 \%$ do total

O terceiro modelo organizador de pensamento identificado é resultado do agrupamento das respostas nas quais se atribuiu o conflito a algum tipo de sentimento. $\mathrm{O}$ primeiro submodelo $3 \mathrm{~A}$ foi aquele em que os respondentes atribuíram o problema ao ciúme de uma das partes representando $58 \%$ das afirmações obtidas neste modelo. O submodelo $3 \mathrm{~B}$ reuniu, por sua vez as respostas daqueles sujeitos que associaram o conflito a um possível final de relacionamento entre os envolvidos perfazendo $20 \%$ das respostas obtidas. O terceiro submodelo, 3C, é o agrupamento das respostas daqueles que afirmaram que a situação poderia ser entendida como inerente a um relacionamento com um total de $22 \%$ deste item.

Exemplos de respostas:

Submodelo 3A ..Ciúme/Desconfiança

"Mulher quando briga com homem é porque: é uma mulher desconfiada."

F14.6A(1.3)03

"Mulher quando briga com homem é porque: desconfiou de alguma coisa."

M15.7A(1.1)03

"Mulher quando briga com homem é porque: ela desconfia do marido, pensa que está com outra." $\mathrm{M} 15.7 \mathrm{~B}(1.1) 03$

"Mulher quando briga com homem é porque: acha que foi traída." $\quad \mathrm{M} 14.8 \mathrm{~B}(2.2) 04$

"Mulher quando briga com homem é porque: por ciúmes, por cismas mesmo."

$\mathrm{F} 14.8 \mathrm{~A}(1.9) 16$

Submodelo 3B Final do relacionamento

"Mulher quando briga com homem é porque: deve estar pedindo a separação." $\mathrm{M} 13.5 \mathrm{~B}(1.1) 07$

"Mulher quando briga com homem é porque: quer outro homem." $\quad$ M13.7D(1.3)12

"Mulher quando briga com homem é porque: quer o divórcio e não ama mais."

$\mathrm{M} 12.6 \mathrm{~B}(2.5) 13$

"Mulher quando briga com homem é porque: ela não quer saber mais do homem." 
"Mulher quando briga com homem é porque: não quer ele."

M11.5D(1.6)20

Submodelo 3C Inerente à convivência

"Mulher quando briga com homem é porque: briga de casal."

$\mathrm{M} 13.7 \mathrm{~B}(3.3) 12$

"Mulher quando briga com homem é porque: normal."

$\mathrm{M} 12.7 \mathrm{C}(1.1) 03$

"Mulher quando briga com homem é porque: por causa do casamento, do relacionamento."

M12.5A(1.2)09

"Mulher quando briga com homem é porque: estão discutindo as responsabilidades."

$\mathrm{F} 11.6 \mathrm{~B}(3.3) 11$

"Mulher quando briga com homem é porque: é assim mesmo, eles se amam."

F11.5D(1.5) 18

\begin{tabular}{|c|c|c|c|c|c|}
\hline \multicolumn{2}{|c|}{ Submodelo 3A } & \multicolumn{2}{c|}{ Submodelo 3B } & \multicolumn{2}{c|}{ Submodelo 3C } \\
\hline \multicolumn{2}{|c|}{41} & \multicolumn{2}{|c|}{14} & $\mathrm{~F}$ & $\mathrm{M}$ \\
\hline $\mathrm{F}$ & $\mathrm{M}$ & $\mathrm{F}$ & $\mathrm{M}$ & 6 & 10 \\
\hline 23 & 18 & 7 & 7 & 6 \\
\hline
\end{tabular}

\section{Modelo 4 - AGRESSÃO MOTIVADA POR CONDUTA}

Total geral de respostas para este modelo: 14

$6 \%$ do total

O modelo 4 foi o resultado do agrupamento das respostas em que os sujeitos entenderam o conflito como motivado por alguma conduta inadequada da parte do agredido. O submodelo $4 \mathrm{~A}$ referiu-se a algum tipo de vício com $93 \%$ das respostas. O submodelo $4 \mathrm{~B}$ fez uma associação com problemas de origem financeira representando $7 \%$ do total.

Exemplos de respostas:

Submodelo 4A Vício

"Mulher quando briga com homem é porque: ele gasta todo o seu salário com bebida e mulheres."

$\mathrm{F} 14.6 \mathrm{~A}(2.3) 03$

"Mulher quando briga com homem é porque: ele chega em casa completamente bêbado." F12.6C(6.7)19

"Mulher quando briga com homem é porque: ele só bebe." $\mathrm{F} 11.5 \mathrm{C}(2.3) 18$

"Mulher quando briga com homem é porque: por causa da bebida." F11.5A(1.5)18

"Mulher quando briga com homem é porque: por algum vício." F13.7D(3.3)09

Submodelo 4B Problemas financeiros

"Mulher quando briga com homem é porque: o homem não trabalha e não tem dinheiro."

M12.6B(3.5)13 
Submodelo 4C Falta de respeito/postura

OBS: Não houve incidência desta lógica nas afirmações feitas para esta questão.

Submodelo 4D Maledicência

OBS: Não houve incidência desta lógica nas afirmações feitas para esta questão.

\begin{tabular}{|c|c|c|c|c|c|c|c|}
\hline \multicolumn{2}{|c|}{ Submodelo 4A } & \multicolumn{2}{c|}{ Submodelo 4B } & \multicolumn{2}{c|}{ Submodelo 4C } & \multicolumn{2}{c|}{ Submodelo 4D } \\
\hline \multicolumn{2}{|c|}{13} & \multicolumn{2}{|c|}{1} & \multicolumn{2}{c|}{0} & \multicolumn{2}{c|}{0} \\
\hline $\mathrm{F}$ & $\mathrm{M}$ & $\mathrm{F}$ & $\mathrm{M}$ & $\mathrm{F}$ & $\mathrm{M}$ & $\mathrm{F}$ & $\mathrm{M}$ \\
\hline 9 & 4 & 0 & 1 & 0 & 0 & 0 & 0 \\
\hline
\end{tabular}

\section{Outros}

Motivações diversas.

Total geral de respostas nesta condição: 8

$4 \%$ do total

Exemplos de respostas:

"Mulher briga com homem é porque: tem vergonha do homem."

M13.6C(1.4)08

"Mulher quando briga com homem é porque: frescura."

$\mathrm{F} 14.8 \mathrm{~B}(6.7) 16$

"Homem quando briga com mulher é porque: mulher não tem nada que brigar com homem, ela vai levar a pior."

$\mathrm{F} 12.6 \mathrm{~B}(8.8) 19$

\begin{tabular}{|c|c|}
\hline \multicolumn{2}{|c|}{ Outros } \\
\hline \multicolumn{2}{|c|}{8} \\
\hline F & M \\
\hline 2 & 6 \\
\hline
\end{tabular}

\section{Comentários sobre os dados obtidos}

\section{Questão 8:}

Os resultados obtidos a partir das respostas dadas à oitava questão que propunha a hipótese de um conflito também entre personagens do sexo oposto sendo o agressor do sexo feminino foi objeto dos gráficos de números 21 e 22. O primeiro apresenta a tendência generalizada de aplicação da lógica de cada submodelo, enquanto o segundo demonstra a mesma tendência detalhada por sexo do respondente. 
Gráfico 21

MODELOS APLICADOS

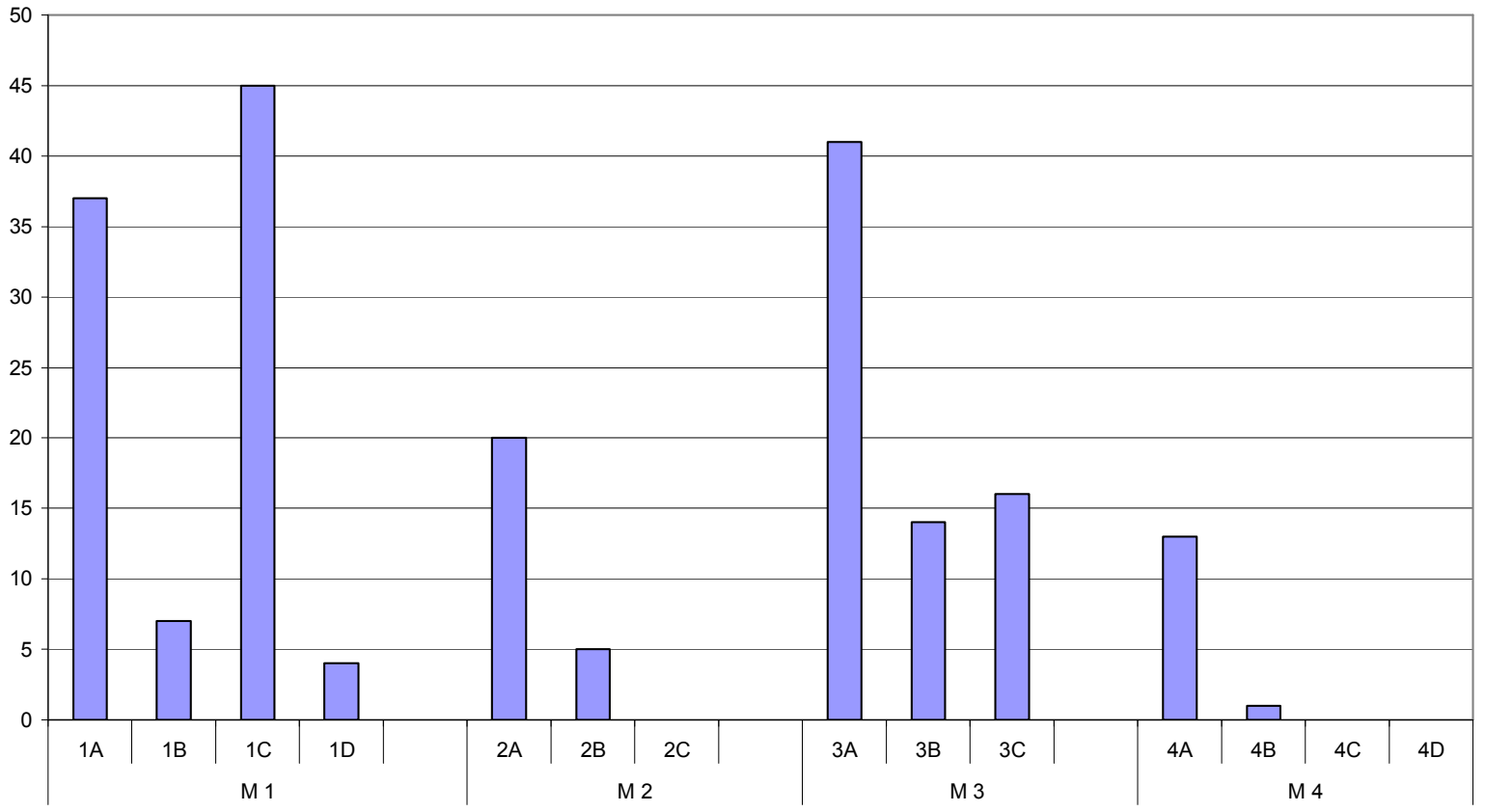

Gráfico 22

MODELOS APLICADOS POR SEXO

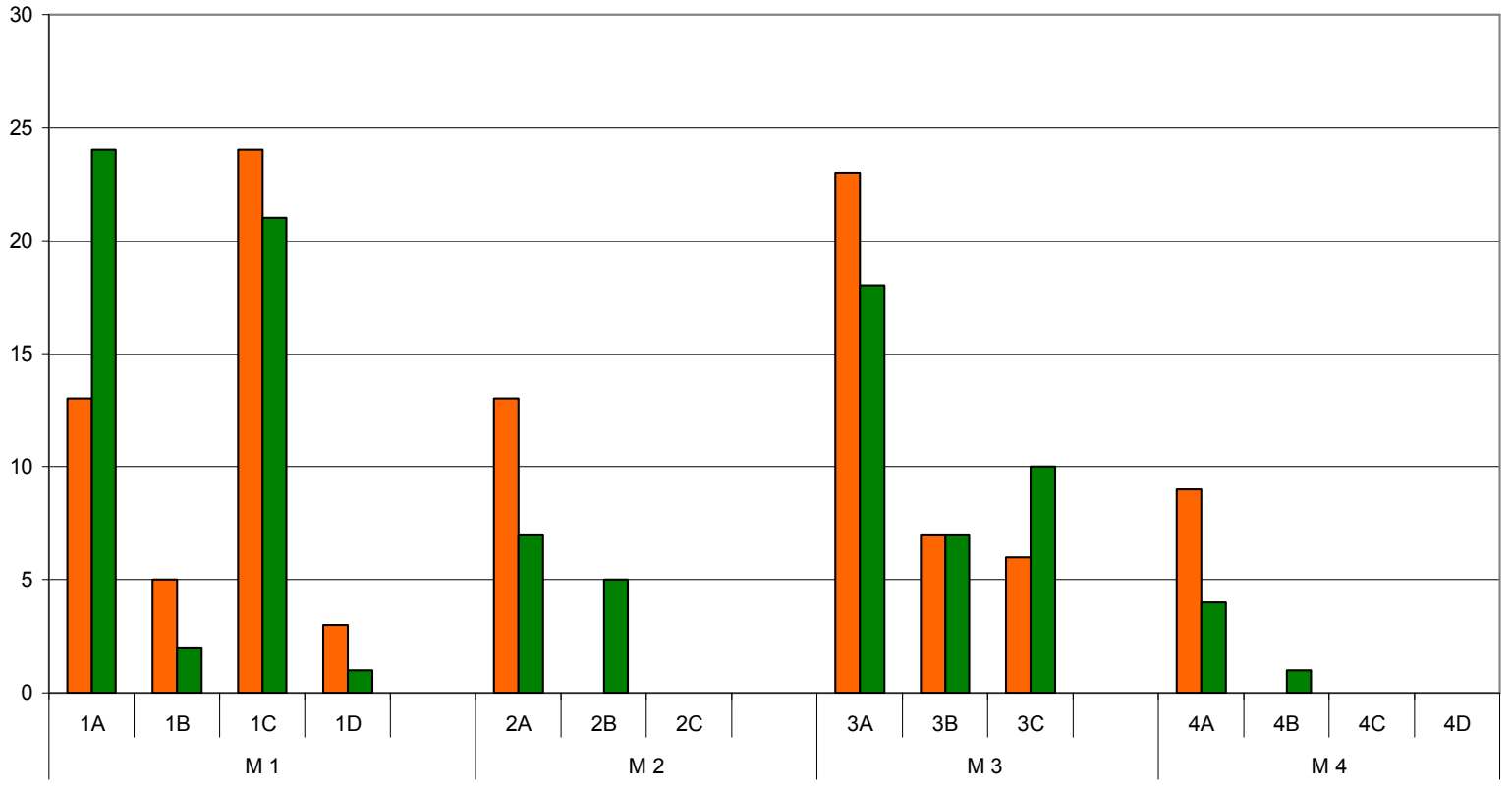

$\square$ Sexo feminino $\square$ Sexo masculino

Os dados obtidos apontam para a predominância do modelo 1, "Justifica a agressão" quando do embate mulher/homem, provocado pela primeira, pautado essencialmente em uma possível decepção amorosa (submodelo 1C). Seguem-se as hipóteses da desconfiança do parceiro (submodelo 3A) e da traição (submodelo 1A) com resultado praticamente equivalente, invertendo-se, no entanto, a tendência quanto ao sexo do respondente. 


\section{Comparação entre os dados}

\section{Questões 7 e 8}

Os gráficos 23 e 24 apresentam um comparativo entre os desempenhos obtidos por cada um dos modelos aplicados quando da hipótese de conflitos entre personagens do sexo oposto, sendo o primeiro aquele em que o agente promotor do conflito é o personagem do sexo masculino e o segundo do sexo feminino respectivamente.

\section{Gráfico 23}

QUESTÃO 7 - MODELOS APLICADOS

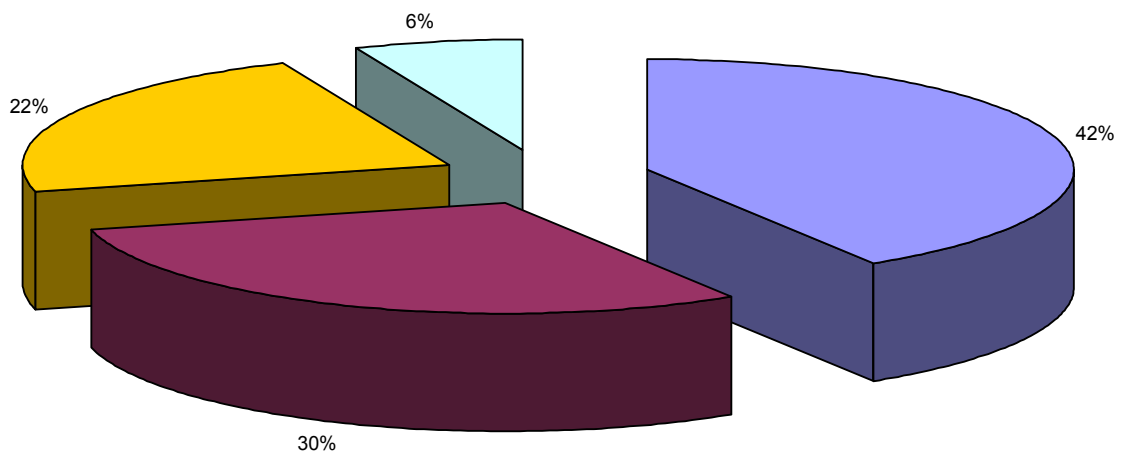

$\square \mathrm{M} 1 \square \mathrm{M} 2 \square \mathrm{M} 3 \mathrm{M} 4$

Gráfico 24

QUESTÃO 8 - MODELOS APLICADOS

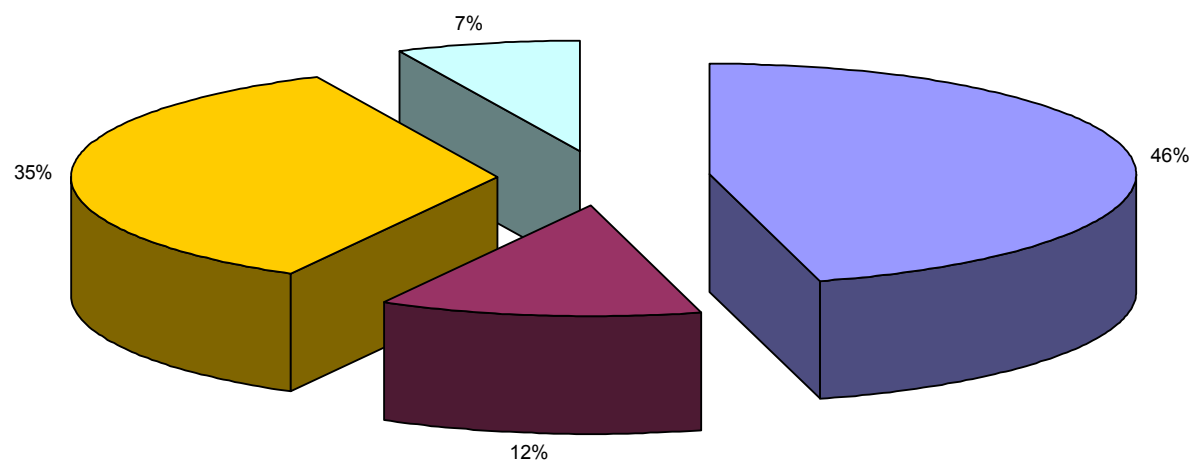

$\square \mathrm{M} 1 \square \mathrm{M} 2 \mathrm{MM} 3 \mathrm{M} 4$ 
A partir do comparativo da representatividade dos modelos aplicados é possível verificar que há uma inversão na tendência de representação do conflito priorizando o modelo 2 ("Recrimina a agressão", a partir do desmerecimento da agredida) aplicado à sétima questão frente ao modelo 3 (“Agressão motivada por sentimento”) na oitava questão, ou seja, quando o agressor era do sexo masculino houve uma tendência maior a justificar a agressão em relação à hipótese na qual a agressora seria do sexo feminino.

Pergunta 9:

"Homem quando briga com homem é porque: "

A questão de número nove pretendeu identificar a lógica que os jovens respondentes aplicariam a uma situação hipotética em que, diferentemente do proposto nas duas questões anteriores, agressor e agredido, desta feita, pertenceriam a um mesmo sexo, neste caso ambos do sexo masculino.

\section{Grupo A - Com Juízo de Valor}

\section{Modelo 1 - JUSTIFICA A AGRESSÃO}

Total geral de respostas para este modelo: 43

$20 \%$ do total

O modelo 1, aplicado à questão 9 , é resultado do agrupamento das respostas que os respondentes entenderam ser o agressor motivado por alguma questão suficientemente relevante para justificar a sua atitude.

O submodelo 1A, tal qual nas questões 7 e 8, foi resultado da inferência de uma traição à motivação do agressor. Este submodelo representou 54\% do total. O submodelo 1B, a desqualificação do agredido, não foi aplicado a esta questão. $\mathrm{O}$ submodelo $1 \mathrm{C}$, atribuindo a agressão a uma provável provocação do agredido, obteve $46 \%$ das respostas deste modelo.

Exemplos de respostas:

Submodelo 1A Traição

"Homem quando briga com homem é porque: roubou a sua namorada."

$\mathrm{M} 12.6 \mathrm{~B}(3.5) 13$

"Homem quando briga com homem é porque: ele traiu com a mulher dele." 
"Homem quando briga com homem é porque: estava namorando com a mulher dele." M11.6B(4.4)08

"Homem quando briga com homem é porque: o outro está namorando com a mulher dele."

$\mathrm{M} 15.8 \mathrm{~B}(3.3) 06$

"Homem quando briga com homem é porque: normalmente é porque descobriu que traiu com a mulher dele."

F14.8A(3.9)16

Submodelo 1B Desqualifica o agredido

OBS: Não houve incidência desta lógica nas afirmações para esta questão.

Submodelo 1C ..Decepção/Provocação

"Homem quando briga com homem é porque: quando está no trânsito faz alguma coisa errada. Ex: ultrapassar no sinal vermelho."

"Homem quando briga com homem é porque: o outro está falando mal dele sem motivo."

F13.6A(1.1)05

"Homem quando briga com homem é porque: ele xingou a mãe dele." M13.6C(4.4)08

"Homem quando briga com homem é porque: mexeram com o seu filho."

$\mathrm{F} 12.6 \mathrm{C}(5.7) 19$

"Homem quando briga com homem é porque: não gostou do que ele fez e eu acho que foi provocação dele."

M11.5D(1.6)20

Submodelo 1D Revide/Vingança

OBS: Não houve incidência desta lógica nas afirmações para esta questão.

\begin{tabular}{|c|c|c|c|c|c|c|c|}
\hline \multicolumn{2}{|c|}{ Submodelo 1A } & \multicolumn{2}{c|}{ Submodelo 1B } & \multicolumn{2}{c|}{ Submodelo 1C } & \multicolumn{2}{c|}{ Submodelo 1D } \\
\hline \multicolumn{2}{|c|}{23} & \multicolumn{2}{|c|}{0} & \multicolumn{2}{c|}{20} & \multicolumn{2}{c|}{0} \\
\hline F & M & F & M & F & M & F & M \\
\hline 11 & 12 & 0 & 0 & 9 & 11 & 0 & 0 \\
\hline
\end{tabular}

\section{Modelo 2 - RECRIMINA A AGRESSÃO}

Total geral de respostas deste modelo: 43 $20 \%$ do total

O modelo 2 é o agrupamento das respostas dos sujeitos que indicaram assumir a posição de serem contrários à situação conflituosa pautando a sua justificativa na responsabilidade do agressor.

$\mathrm{O}$ submodelo $2 \mathrm{~A}$ é aquele em que os respondentes desqualificaram o agressor representando $51 \%$ das respostas. O submodelo $2 \mathrm{~B}$, exclusivamente na questão 9 , remete-se a uma conduta tipicamente masculina, perfazendo $49 \%$ das respostas obtidas. 
Exemplos de respostas:

Submodelo 2A Desqualifica o agressor

"Homem quando briga com homem é porque: ele mexeu com ele e o ignorante foi pra cima do outro."

$\mathrm{F} 11.5 \mathrm{D}(4.5) 18$

"Homem quando briga com homem é porque: não sabe valorizar uma amizade, faz tudo na maldade."

F12.6B(6.8)19

"Homem quando briga com homem é porque: não tem vergonha na cara."

F12.6A(2.4)19

"Homem quando briga com homem é porque: é briguento, irresponsável."

F11.5A(3.5)18

"Homem quando briga com homem é porque: boiola."

M11.5D(4.6)20

Submodelo 2B Inabilidade emocional

"Homem quando briga com homem é porque: quer impressionar a mulher."

$\mathrm{M} 12.6 \mathrm{~A}(4.5) 13$

"Homem quando briga com homem é porque: quer aparecer para as mulheres."

F12.5B(4.4)08

"Homem quando briga com homem porque: pra se amostrar pra uma mulher, provar que é forte."

$\mathrm{F} 11.5 \mathrm{C}(3.3) 18$

"Homem quando briga com homem é porque: se estranhou com o outro, às vezes nem tem motivo, mas vocês sabem como é homem, né?

F13.7D(1.3)09

"Homem quando briga com homem é porque: quer provar a sua honra."

$\mathrm{M} 11.5 \mathrm{~B}(2.5) 20$

Submodelo 2C Recriminação "moral”

OBS: Não houve incidência desta lógica nas afirmações para esta questão.

\begin{tabular}{|c|c|c|c|c|c|}
\hline \multicolumn{2}{|c|}{ Submodelo 2A } & \multicolumn{2}{c|}{ Submodelo 2B } & \multicolumn{2}{c|}{ Submodelo 2C } \\
\hline \multicolumn{2}{|c|}{22} & \multicolumn{2}{|c|}{21} & $\mathrm{~F}$ & $\mathrm{M}$ \\
\hline $\mathrm{F}$ & $\mathrm{M}$ & $\mathrm{F}$ & $\mathrm{M}$ & 0 & 0 \\
\hline 13 & 9 & 13 & 8 & 0 \\
\hline
\end{tabular}


O terceiro modelo organizador de pensamento remete o conflito a algo relacionado a um sentimento, por sua presença, ausência ou ainda como sendo justamente a origem do desentendimento. Em função das respostas obtidas deu origem a três submodelos, 3A, 3B e 3C. O primeiro submodelo, 3A, com $78 \%$ das respostas associou o embate entre os envolvidos a uma questão de ciúme ou desconfiança de um dos parceiros. O submodelo $3 \mathrm{~B}$ remete-se ao final de um relacionamento em que um dos parceiros perde o interesse pelo outro e obteve apenas $4 \%$ das afirmações aplicadas. O submodelo $3 \mathrm{C}$, perfazendo $18 \%$ do total das respostas, associou o embate a algo inerente ao convívio entre pares do mesmo sexo.

Exemplos de respostas:

Submodelo 3A .Ciúme/Desconfiança

"Homem quando briga com homem é porque: o outro deu em cima da sua mulher."

F13.7A(1.3)09

"Homem quando briga com homem é porque: mexeu com a mulher dele."

M11.6C(1.1)08

"Homem quando briga com homem é porque: tem mulher no meio." $\quad \mathrm{M} 12.5 \mathrm{C}(1.5) 09$

"Homem quando briga com homem é porque: ele está com ciúmes da mulher dele."

$\mathrm{M} 12.6 \mathrm{~B}(4.5) 13$

"Homem quando briga com homem é porque: gostam da mesma mulher."

M12.7D(1.1)03

Submodelo 3B Final de relacionamento

"Homem quando briga com homem é porque: não gosta mais do seu companheiro."

$\mathrm{M} 13.5 \mathrm{~B}(1.1) 07$

"Homem quando briga com homem é porque: se interessou por outro homem."

$\mathrm{M} 15.8 \mathrm{~A}(2.3) 06$

Submodelo 3C Inerente a convivência

"Homem quando briga com homem é porque: tem algum motivo que os leva a agir dessa maneira, mas geralmente estão com a 'cabeça quente' e não pensam que ninguém ganha nada brigando."

F13.8A(1.3)03

"Homem quando briga com homem é porque: não conhecem a frase 'paz e amor' e se desentendem por coisas banais."

$\mathrm{M} 14.8 \mathrm{~B}(2.2) 04$

"Homem quando briga com homem é porque: não estão se entendendo porque quando um não quer dois não brigam."

$\mathrm{M} 14.6 \mathrm{~B}(1.1) 02$

"Homem quando briga com homem é porque: estão discutindo sobre algum assunto." 
"Homem quando briga com homem é porque: eles se desentenderam." M11.5C(1.5)20

\begin{tabular}{|c|c|c|c|c|c|}
\hline \multicolumn{2}{|c|}{ Submodelo 3A } & \multicolumn{2}{c|}{ Submodelo 3B } & \multicolumn{2}{c|}{ Submodelo 3C } \\
\hline \multicolumn{2}{|c|}{73} & \multicolumn{2}{|c|}{4} & F & M \\
\hline F & M & F & M & 4 & 13 \\
\hline 38 & 35 & 1 & 3 & 4 \\
\hline
\end{tabular}

Modelo 4 - CONDUTA

Total geral das respostas deste modelo: 27

$13 \%$ do total

$\mathrm{O}$ quarto modelo reuniu os questionários cujas respostas estiveram associadas a alguma postura entendida como inapropriada da parte dos personagens do conflito. Este modelo gerou os submodelos, $4 \mathrm{~A}$ e $4 \mathrm{~B}$, com 78 e $22 \%$ de representatividade respectivamente. O primeiro submodelo, 4A, teve respostas em associação direta ao vício enquanto o segundo, 4B, apresentou afirmações relacionadas a problemas financeiros.

Exemplos de respostas:

Submodelo 4A Vício

"Homem quando briga com homem é porque: fica bêbado e começa a bater no outro."

$\mathrm{M} 12.5 \mathrm{C}(5.5) 09$

"Homem quando briga com homem é porque: está bêbado ou drogado e começa a arrumar confusão."

F12.6B(1.8)19

"Homem quando briga com homem é porque: deve ter bebido muito."

$\mathrm{F} 11.6 \mathrm{C}(2.7) 11$

"Homem quando briga com homem é porque: por causa de bebida ou jogo."

F14.8A(8.9)16

"Homem quando briga com homem é porque: geralmente o que leva à briga de homem é bebida, droga e etc."

F14.8A(7.9)16

Submodelo 4B

Problemas financeiros

"Homem quando briga com homem é porque: por causa de dinheiro." M15.6C(1.1)01

"Homem quando briga com homem é porque: não pagar o que deve." M13.6C(3.4)08

"Homem quando briga com homem é porque: deve grana."

$\mathrm{M} 12.5 \mathrm{C}(2.5) 09$

"Homem quando briga com homem é porque: tem divida e não quer pagar."

F11.6A(1.1)11

Submodelo $4 \mathrm{C}$ Falta de respeito/postura

OBS: Não houve incidência desta lógica nas afirmações para esta questão. 
Submodelo 4D

Maledicência

OBS: Não houve incidência desta lógica nas afirmações para esta questão.

\begin{tabular}{|c|c|c|c|c|c|c|c|}
\hline \multicolumn{2}{|c|}{ Submodelo 4A } & \multicolumn{2}{c|}{ Submodelo 4B } & \multicolumn{2}{c|}{ Submodelo 4C } & \multicolumn{2}{c|}{ Submodelo 4D } \\
\hline \multicolumn{2}{|c|}{21} & \multicolumn{2}{|c|}{6} & \multicolumn{2}{c|}{0} & \multicolumn{2}{c|}{0} \\
\hline $\mathrm{F}$ & $\mathrm{M}$ & $\mathrm{F}$ & $\mathrm{M}$ & $\mathrm{F}$ & $\mathrm{M}$ & $\mathrm{F}$ & $\mathrm{M}$ \\
\hline 11 & 10 & 2 & 4 & 0 & 0 & 0 & 0 \\
\hline
\end{tabular}

\section{Outros}

Motivações diversas.

Total geral de respostas nesta condição: 4

$2 \%$ do total

Exemplos de respostas:

"Homem quando briga com homem é porque: quando homem quer brigar não tem o que fazer."

$\mathrm{F} 11.6 \mathrm{~B}(2.3) 11$

"Homem quando briga com homem é porque: eles não tem nada para fazer."

F12. 6B(7.8)19

\begin{tabular}{|c|c|}
\hline \multicolumn{2}{|c|}{ Outros } \\
\hline \multicolumn{2}{|c|}{4} \\
\hline $\mathrm{F}$ & $\mathrm{M}$ \\
\hline 3 & 1 \\
\hline
\end{tabular}

\section{ANÁLISE DOS DADOS OBTIDOS \\ Questão 9:}

Os gráficos 25 e 26 apresentam os resultados mais evidentes da lógica aplicada diante da hipótese de um conflito de interesses entre pares sendo ambos do mesmo sexo.

O gráfico 25 demonstra a tendência de aplicação dos modelos e submodelos inferidos de maneira geral enquanto o gráfico 26 aponta os modelos aplicados subdivididos por sexo do jovem respondente. 


\section{Gráfico 25}

MODELOS APLICADOS

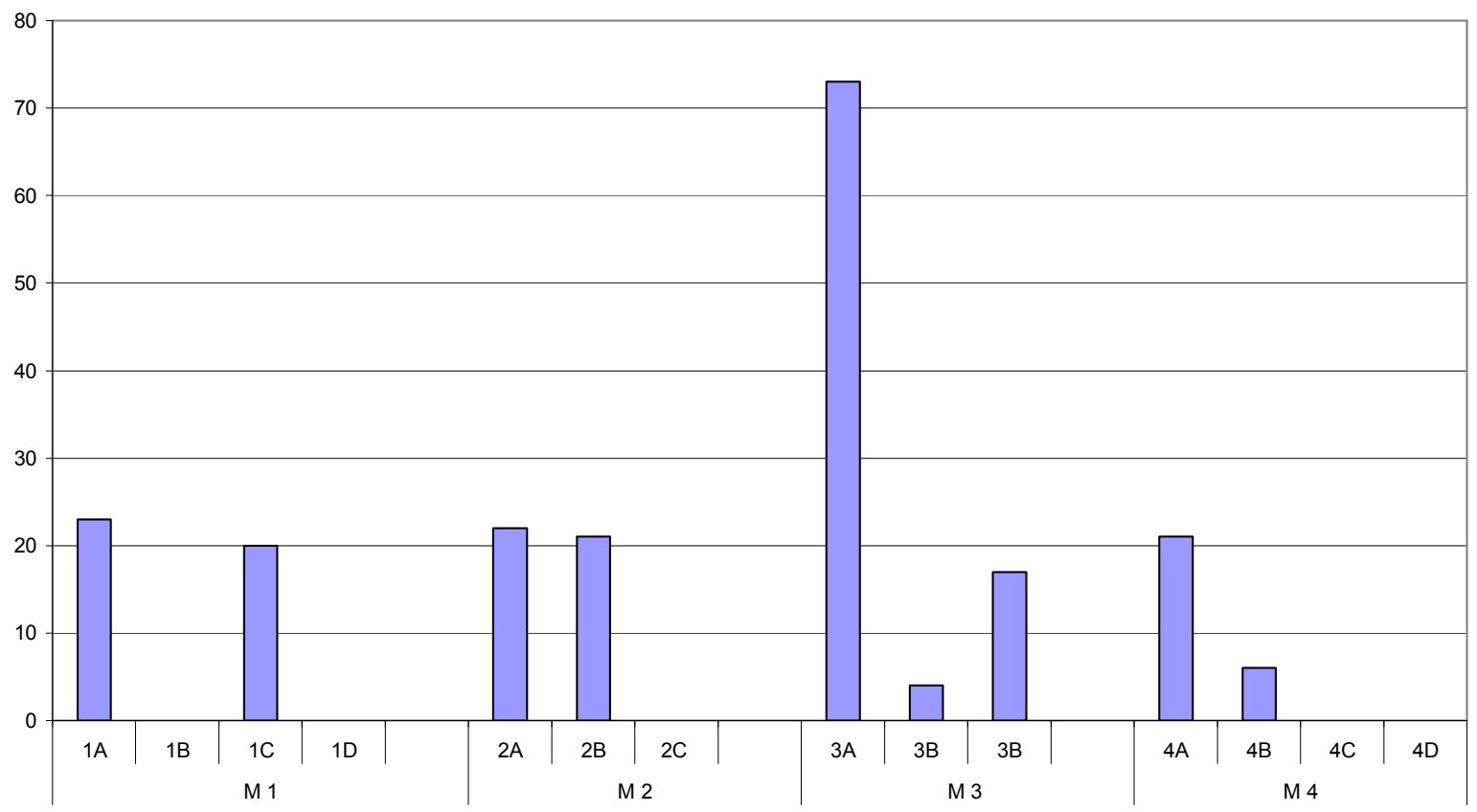

Gráfico 26

MODELOS APLICADOS POR SEXO

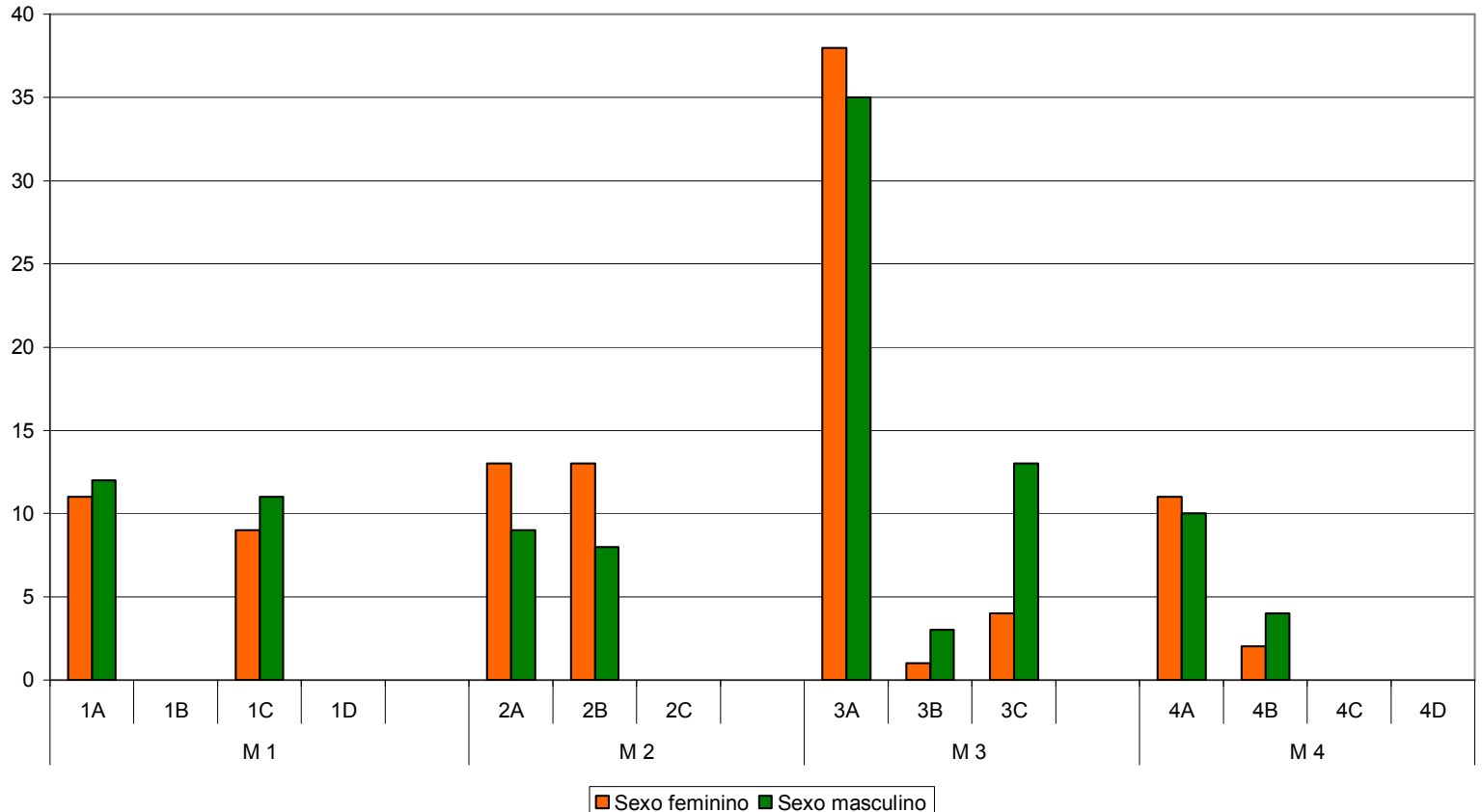

Os dados obtidos apontam para a predominância destacada de uma avaliação da situação sem juízo direto de valor (Grupo B) quando o conflito ocorre entre pares do sexo masculino com resultado evidentemente pautado na desconfiança do agressor (submodelo $3 \mathrm{~A}$ ) de maneira praticamente equivalente a partir das inferências tanto das jovens quanto dos jovens. 
Pergunta 10:

"Mulher quando briga com mulher é porque:

De maneira idêntica à metodologia empregada nas questões anteriores desta série de questões ficou evidenciada uma tendência distinta entre os jovens. Uma parte dos adolescentes assumia, claramente, a defesa de um dos envolvidos no conflito. Tais respostas, como anteriormente, foram objeto de análise do "Grupo A". Os jovens que não evidenciaram assumir partido ou que responsabilizavam a ambos os envolvidos no conflito, por sua vez, foram agrupados na análise do "Grupo B".

Com o objetivo de buscar as equivalências nos raciocínios aplicados às quatro questões da segunda etapa de análise, os modelos organizadores seguiram a mesma ordem das três questões anteriores.

O "Grupo A" propiciou a aplicação dos modelos organizadores de pensamento 1 e 2 enquanto o "Grupo B" permitiu que os modelos 3 e 4 fizessem parte também da análise da última questão do questionário aplicado.

\section{Grupo A - Com Juízo de Valor}

\section{Modelo 1 - JUSTIFICA A AGRESSÃO}

Total geral de respostas para este modelo: 51

$24 \%$ do total

O modelo 1 da questão 10 associou a contenda a algum tipo de problema gerado pelo personagem alvo do desentendimento. O grupo de respondentes do submodelo 1A também fez uma associação direta com um evento de traição (35\% das respostas); o submodelo 1B presente em modelos anteriores, desmerecendo o agredido e, neste caso, alguém também do sexo feminino, não apresentou respostas para a décima questão; o submodelo $1 \mathrm{C}$ que, anteriormente, fazia uma inferência direta a alguma decepção sofrida pela agente promotora da discussão, nesta questão, especificamente foi associada a alguma provocação do personagem alvo em relação à personagem (65\% de representatividade nas respostas).

Exemplos de respostas:

Submodelo 1A Traição

"Mulher quando briga com mulher é porque: ela pegou o namorado dela."

"Mulher quando briga com mulher é porque: a outra roubou o marido dela." 
$\mathrm{M} 12.6 \mathrm{~A}(2.5) 13$

"Mulher quando briga com mulher é porque: ela traiu a amiga com o marido dela e aí sai aquele barraco."

$\mathrm{F} 13.6 \mathrm{~B}(1.3) 05$

"Mulher quando briga com mulher é porque: uma é a fiel e a outra a amante."

F14.6A(1.3)03

"Mulher quando briga com mulher é porque: uma roubou o namorado da outra mulher."

M11.5A(4.4)20

Submodelo 1B

Desqualifica a agredida

OBS: não houve incidência desta lógica nas afirmações feitas para esta questão.

Submodelo 1C

.Decepção/Provocação

"Mulher quando briga com mulher é porque: a outra mulher ficou procurando encrenca."

F11.5D(1.5) 18

"Mulher quando briga com mulher é porque: a outra ficou xingando a mulher de palavrão."

M11.5B(3.5)20

"Mulher quando briga com mulher é porque: a outra ficou irritando ela bastante."

F12.7A(2.2)03

"Mulher quando briga com mulher é porque: ela mexeu com ela, ela implica com ela, por isso elas brigam."

$\mathrm{F} 11.5 \mathrm{D}(4.5) 18$

"Mulher quando briga com mulher é porque: ela tem seus motivos e está com razão."

$\mathrm{F} 14.7 \mathrm{~B}(1.1) 03$

Submodelo 1D Revide/Vingança

OBS: não houve incidências desta lógica nas afirmações feitas para esta questão.

\begin{tabular}{|c|c|c|c|c|c|c|c|}
\hline \multicolumn{2}{|c|}{ Submodelo 1A } & \multicolumn{2}{c|}{ Submodelo 1B } & \multicolumn{2}{c|}{ Submodelo 1C } & \multicolumn{2}{c|}{ Submodelo 1D } \\
\hline \multicolumn{2}{|c|}{18} & \multicolumn{2}{|c|}{0} & \multicolumn{2}{c|}{33} & \multicolumn{2}{c|}{0} \\
\hline F & $\mathrm{M}$ & $\mathrm{F}$ & $\mathrm{M}$ & $\mathrm{F}$ & $\mathrm{M}$ & $\mathrm{F}$ & $\mathrm{M}$ \\
\hline 5 & 13 & 0 & 0 & 15 & 18 & 0 & 0 \\
\hline
\end{tabular}

\section{Modelo 2 - RECRIMINA A AGRESSÃO}

Total geral de respostas para este modelo: 26

$12 \%$ do total

O modelo 2 é resultado do agrupamento das respostas em que os sujeitos entenderam que o conflito não se justifica. $\mathrm{O}$ submodelo $2 \mathrm{~A}$, recrimina a contenda desmerecendo a agressora e obteve $23 \%$ das respostas do modelo. O submodelo $2 \mathrm{~B}$, com um total de $65 \%$ 
deste modelo, associou a inabilidade emocional inerente à atitude da agressora a uma situação mal resolvida da parte da própria promotora do confronto. $\mathrm{O}$ submodelo $2 \mathrm{C}$, com $12 \%$ das respostas, introduz uma modalidade não aplicada às questões anteriores, uma recriminação pautada em motivos religiosos.

Exemplos de respostas:

Submodelo 2A Desqualifica a agressora

"Mulher quando briga com mulher é porque: é biruta, deve estar com falta de homem."

$\mathrm{F} 11.5 \mathrm{~B}(4.5) 18$

"Mulher quando briga com mulher é porque: tem mulher que é galinha, pega tudo o que vê pela frente, não respeita ninguém."

$\mathrm{F} 14.8 \mathrm{~B}(7.7) 16$

"Mulher quando briga com mulher é porque: por safadeza."

$\mathrm{F} 13.7 \mathrm{~A}(2.3) 09$

"Mulher quando briga com mulher é porque: é vagabunda e não presta."

F14.8A(4.9)16

Submodelo 2B Inabilidade emocional

"Mulher quando briga com mulher é porque: está com inveja da outra que está namorando um gato."

$\mathrm{M} 14.7 \mathrm{C}(1.1) 03$

"Mulher quando briga com mulher é porque: deve estar com inveja da outra."

$\mathrm{F} 12.5 \mathrm{~A}(1.2) 08$

"Mulher quando briga com mulher é porque: tem inveja da outra mulher."

F13.5A(1.1)03

"Mulher quando briga com mulher é porque: a outra está namorando um cara certinho."

$\mathrm{M} 14.8 \mathrm{~A}(1.2) 04$

Submodelo 2C Recriminação "moral”

"Mulher quando briga com mulher é porque: pensa que sabe o que está fazendo mas sinceramente não sabe ser amiga de verdade... não agrada a Deus fazendo coisas erradas e brigando."

$\mathrm{F} 12.6 \mathrm{~B}(6.8) 19$

"Mulher quando briga com mulher é porque: é folgada e também porque não ora."

F13.7A(3.3)09

"Mulher quando briga com mulher é porque: está seguindo pelo mau caminho, mas se continuar assim vai se dar mal."

M12.7D(1.1)03 


\begin{tabular}{|c|c|c|c|c|c|}
\hline \multicolumn{2}{|c|}{ Submodelo 2A } & \multicolumn{2}{c|}{ Submodelo 2B } & \multicolumn{2}{c|}{ Submodelo 2C } \\
\hline \multicolumn{2}{|c|}{6} & \multicolumn{2}{c|}{17} & $\mathrm{~F}$ & $\mathrm{M}$ \\
\hline $\mathrm{F}$ & $\mathrm{M}$ & $\mathrm{F}$ & $\mathrm{M}$ & 2 & 1 \\
\hline 4 & 2 & 8 & 9 & & 3 \\
\hline
\end{tabular}

\section{Grupo B - Sem Juízo de Valor}

\section{Modelo 3 - SENTIMENTO}

Total geral das respostas deste modelo: 102

$48 \%$ do total

A inferência mais freqüente dos sujeitos participantes de nossa pesquisa para a décima questão remeteu-se a um sentimento. No caso específico da décima questão, o ciúme, que foi o submodelo $3 \mathrm{~A}$ das respostas 7,8 e 9 , teve além do significado mais freqüente também uma certa conotação de disputa. O submodelo $3 \mathrm{~A}$ representou $92 \%$ do total das respostas obtidas neste modelo. $\mathrm{O}$ submodelo $3 \mathrm{~B}$ associado à ausência ou à superação de um sentimento também aqui remeteu-se ao final de um relacionamento perfazendo um total de $8 \%$ das respostas. No caso específico do submodelo $3 \mathrm{~A}$ da questão 10 encontramos três versões distintas, fazendo referência ao final de um relacionamento entre pares de sexo oposto, pares de mesmo sexo ou ainda ao final de uma amizade.

Exemplos de respostas:

Submodelo 3A Ciúme/Desconfiança

"Mulher quando briga com mulher é porque: pode ser por causa de homem porque uma mulher não pode ver um homem bonito que já se apaixona."

$\mathrm{M} 12.5 \mathrm{C}(5.5) 09$

"Mulher quando briga com mulher é porque: pelo seu namorado porque não quer perder o grande amor da sua vida."

$\mathrm{F} 11.5 \mathrm{C}(3.3) 18$

"Mulher quando briga com mulher é porque: estão brigando por causa de homem."

F12.6C(7.7)19

"Mulher quando briga com mulher é porque: gostam do mesmo homem e faz aquilo por ele."

$\mathrm{M} 12.6 \mathrm{~A}(4.5) 13$

"Mulher quando briga com mulher é porque: uma quer ficar com o namorado da outra."

$\mathrm{M} 14.6 \mathrm{C}(1.1) 02$

Submodelo 3B Final de relacionamento

"Mulher quando briga com mulher é porque: o homem a dispensou." M15.7A(1.1)03

"Mulher quando briga com mulher é porque: uma não quer mais ficar com a outra." 
"Mulher quando briga com mulher é porque: ela se interessou por outra mulher."

$\mathrm{M} 15.8 \mathrm{~A}(2.3) 06$

"Mulher quando briga com mulher é porque: não estão mais se dando bem uma com a outra."

M14.7D(1.2)03

"Mulher quando briga com mulher é porque: não são mais amigas e agora viraram inimigas.”

$\mathrm{F} 12.5 \mathrm{~B}(2.4) 08$

Submodelo 3C Inerente à convivência

OBS: Não houve incidência desta lógica nas afirmações feitas para esta questão.

\begin{tabular}{|c|c|c|c|c|c|}
\hline \multicolumn{2}{|c|}{ Submodelo 3A } & \multicolumn{2}{c|}{ Submodelo 3B } & \multicolumn{2}{c|}{ Submodelo 3C } \\
\hline \multicolumn{2}{|c|}{94} & \multicolumn{2}{|c|}{8} & $\mathrm{~F}$ & $\mathrm{M}$ \\
\hline $\mathrm{F}$ & $\mathrm{M}$ & $\mathrm{F}$ & $\mathrm{M}$ & 0 & 0 \\
\hline 50 & 44 & 2 & 6 & 0 \\
\hline
\end{tabular}

Modelo 4 - CONDUTA

Total geral das respostas deste modelo: 26

$12 \%$ do total

Os sujeitos cujas respostas foram agrupadas neste modelo de pensamento associaram o conflito entre pares do sexo feminino a um problema de conduta. Diferentemente das questões em que um dos envolvidos era do sexo masculino, a décima questão não registrou nenhuma incidência de afirmativas associadas ao vício ou a problemas financeiros. As respostas concentraram-se em lógicas predominantemente associadas à falta de postura ou à maledicência. O primeiro sub-modelo encontrado, $4 \mathrm{C}$ obteve $65 \%$ das respostas totais dos raciocínios que se remetiam à conduta, enquanto o sub-modelo $4 \mathrm{D}$ obteve os demais $35 \%$.

Exemplos de respostas:

Submodelo 4A Vício

OBS: Não houve incidência desta lógica nas afirmações feitas para esta questão.

Submodelo 4B Problemas financeiros

OBS: Não houve incidência desta lógica nas afirmações feitas para esta questão.

Submodelo 4C Falta de respeito/postura

"Mulher quando briga com mulher é porque: não tem vergonha na cara."

$\mathrm{F} 12.6 \mathrm{~B}(7.8) 19$

"Mulher quando briga com mulher é porque: não tem vergonha de brigar."

M13.6C(1.4)08

"Mulher quando briga com mulher é porque: são duas barraqueiras." F12.6B(4.8)19 
"Mulher quando briga com mulher é porque: as duas não tem respeito uma com a outra e não sabem conversar."

F15.6A(1.1)02

"Mulher quando briga com mulher é porque: não tem educação."

$\mathrm{F} 14.8 \mathrm{~B}(1.7) 16$

Submodelo 4D Maledicência

"Mulher quando briga com mulher é porque: fofoca."

$\mathrm{F} 11.5 \mathrm{~A}(3.5) 18$

"Mulher quando briga com mulher é porque: por causa de fofoquinha, que uma fala para uma, fala para outra e forma fofoca."

F11.6B(1.3)11

"Mulher quando briga com mulher é porque: porque uma está falando da outra."

F13.6A(1.1)05

"Mulher quando briga com mulher é porque: uma fala mal da outra." M13.7A(2.3)12

\begin{tabular}{|c|c|c|c|c|c|c|c|}
\hline \multicolumn{2}{|c|}{ Submodelo 4A } & \multicolumn{2}{|c|}{ Submodelo 4B } & \multicolumn{2}{c|}{ Submodelo 4C } & \multicolumn{2}{c|}{ Submodelo 4D } \\
\hline \multicolumn{2}{|c|}{0} & \multicolumn{2}{|c|}{0} & \multicolumn{2}{c|}{17} & \multicolumn{2}{c|}{9} \\
\hline $\mathrm{F}$ & $\mathrm{M}$ & $\mathrm{F}$ & $\mathrm{M}$ & $\mathrm{F}$ & $\mathrm{M}$ & $\mathrm{F}$ & $\mathrm{M}$ \\
\hline 0 & 0 & 0 & 0 & 9 & 8 & 7 & 2 \\
\hline
\end{tabular}

\section{Outros}

Motivações diversas.

Total geral de respostas nesta condição: 6 $.6 \%$ do total

As respostas agrupadas sob o título de "Outros" foram aquelas cuja lógica não apresentou uma linha de raciocínio em continuidade com as demais.

Exemplos de respostas:

"Mulher quando briga com mulher é porque: quando não toma banho e vai dormir fedendo."

M12.5C(4.5)09

"Mulher quando briga com mulher é porque: uma pega as roupas da outra."

$\mathrm{M} 14.5 \mathrm{D}(2.4) 08$

\begin{tabular}{|c|c|}
\hline \multicolumn{2}{|c|}{ Outros } \\
\hline \multicolumn{2}{|c|}{6} \\
\hline $\mathrm{F}$ & $\mathrm{M}$ \\
\hline 3 & 3 \\
\hline
\end{tabular}




\section{Comentários sobre os dados obtidos}

\section{Questão 10:}

A décima questão teve os resultados obtidos traduzidos nos gráficos 27 e 28, cabendo ao primeiro a demonstração dos modelos e submodelos, aplicados sem nenhum aprofundamento, enquanto o segundo, apresenta a distribuição das respostas de acordo com o sexo do respondente.

Gráfico 27

MODELOS APLICADOS

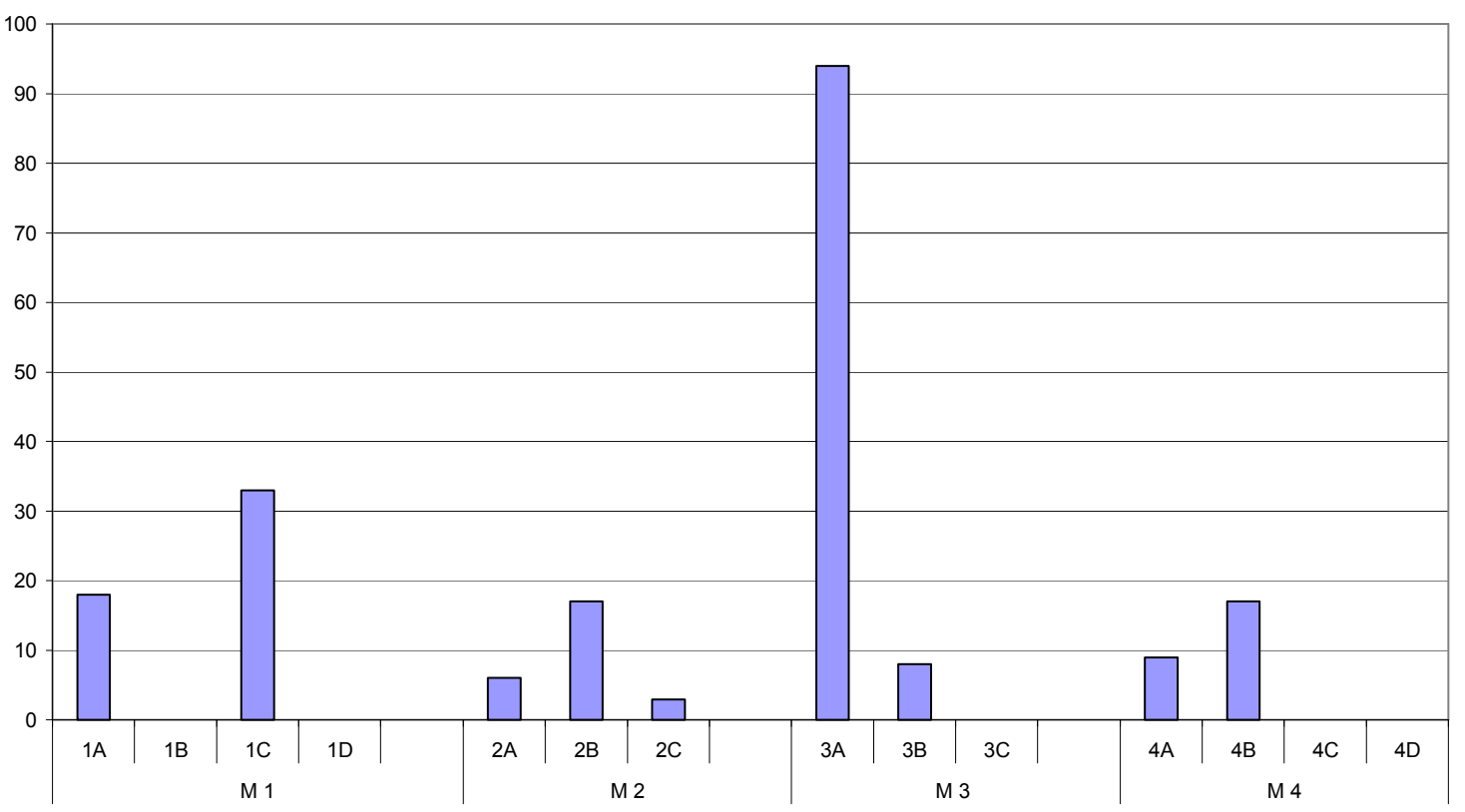

Gráfico 28

MODELOS APLICADOS POR SEXO

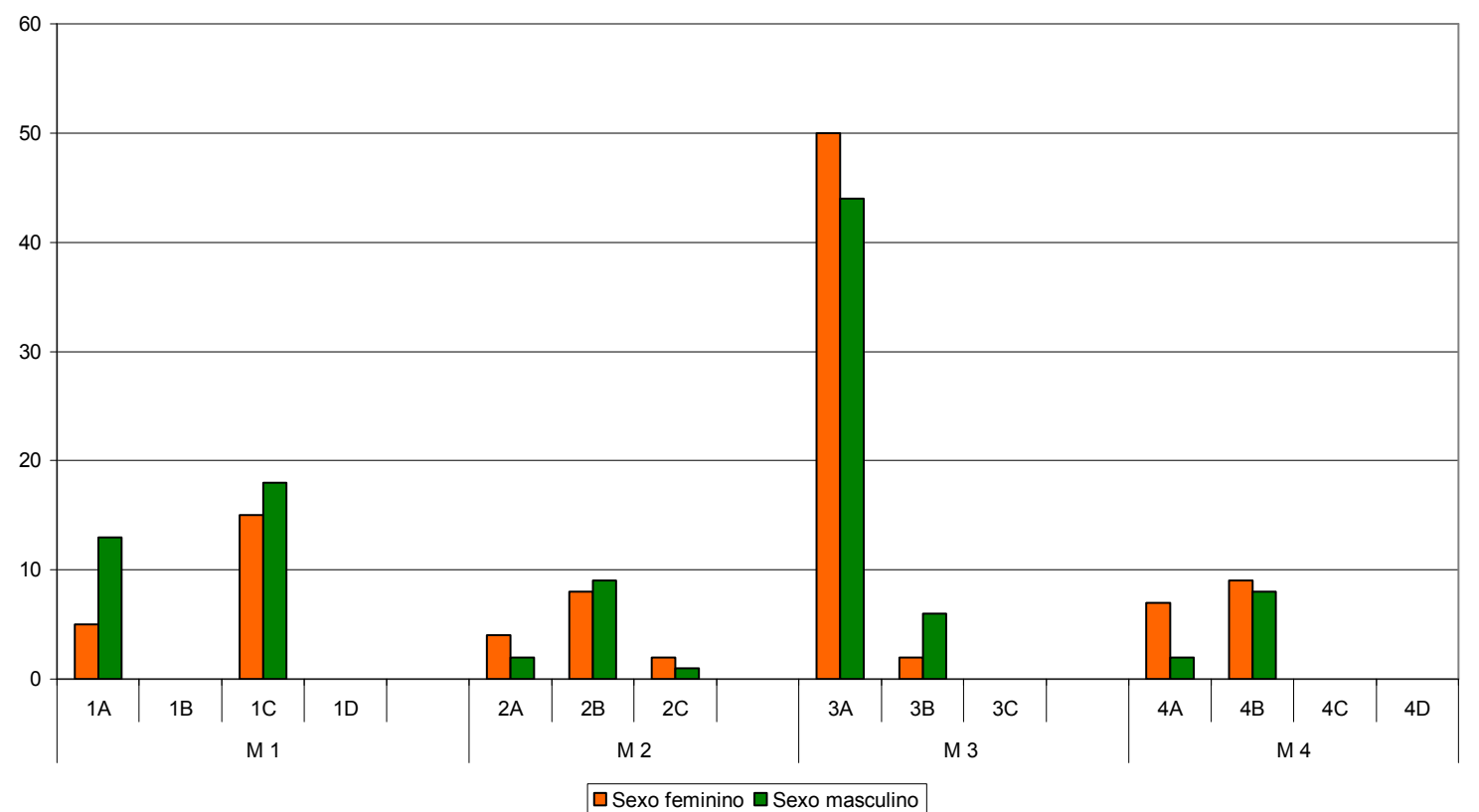


Também quando da hipótese de um conflito entre pares do sexo feminino a representação mais freqüente, de maneira idêntica ao obtido para a questão anterior, onde os pares eram ambos do sexo masculino, a representação mais freqüente esteve pautada na desconfiança em relação a um terceiro envolvido não apontado em nossa questão apresentada.

\section{Comparação entre os dados obtidos}

Questões 9 e 10

Os gráficos 29 e 30 apresentam um comparativo entre os desempenhos obtidos por cada um dos modelos aplicados quando da hipótese de conflitos entre personagens do mesmo sexo oposto, sendo o primeiro aquele em que ambos são do sexo masculino e o segundo do sexo feminino respectivamente.

\section{Gráfico 29}

QUESTÃO 9 - MODELOS APLICADOS

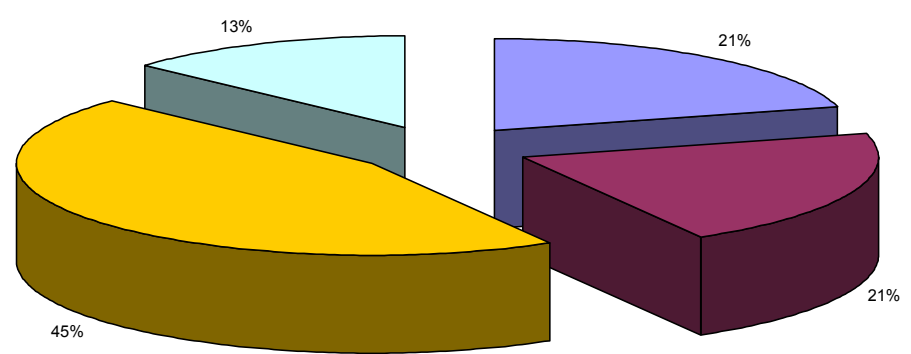

口M1 पM2 वM3 पM4

\section{Gráfico 30}

QUESTÃO 10 - MODELOS APLICADOS

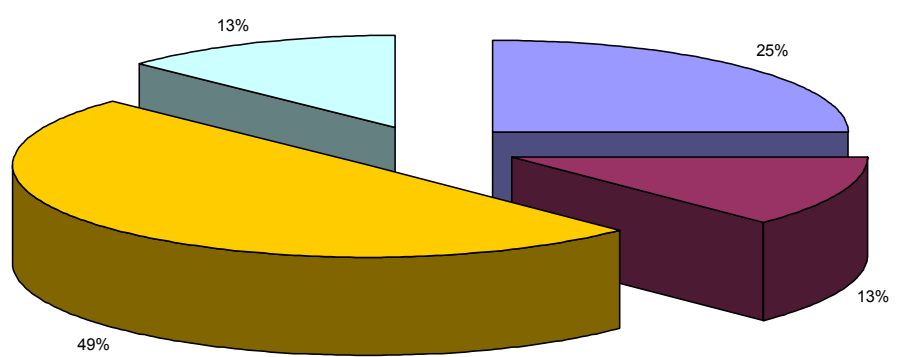


Na comparação entre os modelos aplicados à nona e décima questões, em que ambos os envolvidos pertencem ao mesmo sexo apresenta-se uma tendência muito próxima nas inferências aplicadas a ambas as questões com leve variação na representatividade do modelo 2 ("Recrimina a agressão) cujo índice ligeiramente superior na última questão havia sido distribuído entre os modelos 1 (“Justifica a agressão) e o modelo 3 ("Motivação pautada em sentimentos") da questão anterior. 


\section{ANÁLISE DOS DADOS}

Assumimos por eixo central de nossa pesquisa de campo, a hipótese de que representações sociais dos papéis gênero, entre jovens das camadas populares urbanas, estejam sendo referendadas por crenças, pautadas na distinção entre as feminilidades e as masculinidades, de forma valorativa tendendo a uma hierarquização que gera a subordinação das primeiras em relação às segundas.

Em função desta hipótese, o instrumento aplicado em nossa pesquisa de campo, teve por objetivo desvelar, gradativamente, por intermédio de questionamentos sucessivos, associações nas quais os jovens imputavam atributos qualificativos ao "ser homem" e "ser mulher". Posteriormente, incentivamos afirmativas que evidenciavam sua percepção quanto ao que significaria "ter uma atitude de homem" e "ter uma atitude de mulher". A esta primeira série de afirmações incompletas foram acrescentadas situações de conflitos de interesse, primeiramente entre parceiros do sexo oposto, complementados por outros em que o embate se dava entre pares de mesmo sexo.

Uma vez coletadas as afirmações, optamos por aplicar aos questionários a análise a partir dos pressupostos dos modelos organizadores de pensamento. Esta metodologia permite considerar as mais diferentes possibilidades que os sujeitos encontram para construir hipóteses próprias a partir de um mesmo fenômeno. A lógica que cada sujeito aplica às mais distintas circunstâncias do seu cotidiano resulta nos "modelos" que constrói sobre os fatos. Foram estes "modelos" que orientaram a análise que fizemos a partir das complementações aplicadas às afirmativas incompletas apresentadas.

\section{1. ANÁLISE DOS MODELOS DA PRIMEIRA FASE}

A primeira fase de nossa análise esteve centrada na leitura e tabulação das respostas obtidas das seis afirmativas iniciais, que, pretendiam evidenciar as representações dos jovens frente à legitimação dos papéis de gênero. Tendo em vista a complexidade das combinações possíveis, focadas na apreciação destas questões, voltadas à identificação dos atributos legitimadores de masculinidades e feminilidades, optamos por apontar a característica predominantemente assinalada na seqüência das afirmações subseqüentes. A variável que, efetivamente, nos interessou identificar era a aplicação de valorações, intrínsecas ou explícitas, que implicam em hierarquias ou subordinações de papéis nas associações evidenciadas pelas afirmativas dos jovens. 
Esta forma de avaliar os dados permitiu reconhecer dois eixos centrais que regem a lógica das inferências empregadas pelos respondentes.

Uma parte dos jovens interpretou a legitimação de mulheres e homens, a partir de valores epicenos, pautados exclusivamente na condição humana. Este recorte, entre os jovens participantes, teve as suas afirmativas reunidas naquilo que denominamos: "Associações indiretas". Apesar das repetidas indagações de nossa parte, quase oitenta jovens, mantiveram atributos para os papéis de gênero independentes das justificativas biológicas, daquelas pautadas na sexualidade, ou ainda, pelas variáveis do gênero, propriamente dito.

As respostas do "Grupo A", das associações indiretas, na primeira fase de análise tiveram, por sua vez, duas linhas centrais de raciocínio. A primeira delas associou ao “Trabalho" - "Modelo 1" - a possibilidade de se reconhecer "um homem" ou "uma mulher". Entenderam tais jovens que, o que os torna seres humanos, homens ou mulheres, é a condição de trabalhador(a). A segunda idéia, que sustentou esta maneira de reconhecer a legitimidade dos papéis, foi remetida às "Virtudes" - "Modelo 2", ou "qualidades" do ser humano, recorrendo principalmente ao respeito e à responsabilidade, com relativa conotação, esta última, de qualidade subseqüente à maturidade, ou seja, "ser homem" ("ter atitude de homem") ou "ser mulher" ("ter atitude de mulher") demanda do amadurecimento de uma característica conquistada pelo indivíduo.

Os Modelos 1 e 2, foram citados em proporções praticamente idênticas, entre adolescentes do sexo masculino e feminino (Gráfico 2, página 107). Por sua vez, a distribuição de tais respostas, quando distribuídas em função da faixa etária do participante, demonstrou haver uma tendência um pouco maior pela legitimação dos papéis sociais a partir do "Trabalho" (Modelo 1) até os 12 anos; a partir dos 13 anos há uma disposição maior em atribuir às "Virtudes" (Modelo 2) tal condição (Gráfico 9, página 111).

Ainda que a hierarquização aplicada às questões do "Grupo A", quando totalizada não apresente uma tendência representativa (Gráfico 3, página 108) - exceção feita aos submodelos 1B ("Trabalho" aplicado apenas ao papel masculino) e, 2C, ("Virtude" pautada no caráter e na lisura) - foi possível constatar que o resultado é decorrência, predominantemente, das respostas das jovens do sexo feminino. $\mathrm{Na}$ comparação direta das respostas obtidas, sem hierarquia, 25 destas afirmações foram feitas pelas meninas, contra apenas 14 pelos meninos. Ao observamos as respostas que apresentaram hierarquia em suas proposições, ainda neste mesmo grupo, a tendência demonstrada foi inversa; foram 15 respostas das garotas contra 25 dos garotos. Fica demonstrado, portanto, que, no que diz 
respeito às respostas do "Grupo A", houve uma tendência maior à hierarquização da parte dos respondentes do sexo masculino.

$\mathrm{Na}$ continuidade da análise das seis perguntas iniciais foi instituído o "Grupo B”, que reuniu as afirmativas que fizeram menções pertinentes àquilo que denominamos "Associações diretas", remetendo-se a referências pautadas na condição determinada biologicamente, na sexualidade, ou nas questões pertinentes ao gênero. Este grupo, por sua vez, foi subdivido em três tipos distintos de idéia central adotada.

O primeiro dos modelos organizadores, resultante desta lógica, foi aquele em que seus respondentes fizeram alusão a questões de ordem biológica ("Modelo 3", "Grupo B", primeira fase da análise); o segundo modelo, desta mesma série, foi aquele em que houve uma associação direta à sexualidade do personagem objeto da legitimação ("Modelo 4", "Grupo B”, primeira fase de análise); por último agrupamos as afirmativas que se ativeram a questões efetivamente relacionadas a atributos referendados no universo feminino ou no universo masculino (“Modelo 5”, “Grupo B”, primeira fase da análise).

Em uma comparação direta (Gráficos 1 e 9, páginas 107 e 111), é possível observar que houve uma predominância evidente nas associações diretas com o "sexo" - comum (Modelo 3), praticamente $40 \%$ das afirmações obtidas, relacionadas, especialmente, às determinações genéticas nas afirmativas dos respondentes de 11 a 14 anos. Deste total, a metade, aplicou o submodelo $3 \mathrm{C}$, ou seja, o sexo foi ratificado por questões da sexualidade. A distribuição das quantidades, entre as respostas das moças e dos rapazes, neste submodelo, é equivalente, e, ainda que no conjunto haja um equilíbrio entre a tendência à hierarquização e à não hierarquização dos atributos, apresenta-se uma predominância das respostas sem hierarquia entre as jovens, representando 1 vez e $1 / 2$ a quantidade obtida dos rapazes; em contrapartida naquilo que se refere às afirmativas com hierarquia, a quantidade total das afirmações valorativas obtidas dos jovens é o dobro daquelas advindas das jovens.

O Modelo 4, associado a questões da sexualidade, ou, o "Sexo" - tornado próprio -, sem nenhuma outra variável relacionada, teve baixa representatividade, com a incidência de apenas 2 respostas advindas de sujeitos do sexo masculino.

O Modelo 5, resultado das associações diretas ao gênero, inverteu a tendência dos dois modelos anteriores, dentro do mesmo grupo, apresentando uma predominância evidente de respostas dos participantes do sexo masculino - são 30 respostas, o dobro do obtido a partir das respostas das meninas - (Gráfico 2, página 107). Foi também este, o único modelo em que a não hierarquização de atributos prevaleceu sobre a subordinação nas respostas dadas pelo grupo dos alunos do sexo masculino. Lógica essa que, mostrou ter sido aplicada, 
preferencialmente, pelos sujeitos até os 13 anos de idade (Gráficos comparativos de número 10 a 14, páginas 103 a 105). Os dados obtidos indicam que houve menor tendência a hierarquizar os atributos quando associados à uma condição que, por si só, estabelece uma lógica própria, a noção relacional da interação entre o masculino e o feminino, e que pode incluir perspectivas valorativas próprias.

É possível identificar na apresentação, de forma mais abrangente, que cada um dos modelos adotados pelos adolescentes, isoladamente, apontou para um equilíbrio entre praticamente todas as repostas que aplicaram a hierarquização em relação àquelas que não a aplicaram (Gráfico 3, página 108). No entanto, a partir de um detalhamento das respostas que, efetivamente, subordinaram os atributos das feminilidades às masculinidades, fica demonstrado que houve uma incidência maior de tais pressupostos entre os meninos (Gráfico 4, página 108). Apontando, separadamente, as respostas das meninas (Gráfico 5, página 109), é possível observar que, ainda que, gradativamente, seja decrescente a incidência das respostas sem hierarquia, à medida que aumenta a sua idade, mesmo entre as garotas, tal tendência não chega a se inverter. Entretanto, quando da apreciação das afirmativas obtidas apenas a partir dos participantes do sexo masculino que aplicaram a valoração distinta aos papéis (Gráfico 6, página 109), fica evidenciada a inversão da "igualdade" entre os gêneros à medida que avançam em sua respectiva faixa etária. Se por um lado nos foi possível confirmar que há efetivamente uma inversão na tendência à "igualdade" entre os gêneros a partir dos 13 anos, (Gráfico 7, página 110), evidenciou-se, por outro lado, que é marcadamente por influência dos rapazes que tal tendência se acentua (Gráfico 8, página 110).

\section{2. ANÁLISE COMPLEMENTAR DA PRIMEIRA FASE}

Para além dos dados que foi possível obter na primeira fase de nossa análise, outra tendência cunhava-se marcante à medida que avançávamos na leitura das afirmativas dos jovens. Há, claramente, em suas respostas, uma forma subliminar de imputar hierarquia aos atributos inferidos aos papéis de gênero. A esta disposição, intrínseca, denominamos “Adjetivação hierarquizada".

Uma apuração, mais pormenorizada, dos termos empregados na qualificação de homens e mulheres, demonstrou que, se grande parte dos respondentes buscou conservar, em suas respostas, afirmações "politicamente corretas" ao designar atributos que legitimassem os papéis de gênero, denunciavam, de maneira sutil, que, os significados atribuídos a 
determinadas adjetivações da condição de "ser homem" ou de "ser mulher", eram sensivelmente distintos.

Entre as "qualidades" que nos pareceram merecer maior atenção, destacamos aquelas que tiveram maior incidência. A propriedade denominada "Coragem" teve uma maioria absoluta das menções, perfazendo o total de 113 citações a este predicado em 211 questionários validados. Das 113 menções, 77 foram direcionadas às masculinidades. Acrescente-se a isto, o fato da coragem atribuída aos homens ser claramente distinta da coragem atribuída às mulheres. A primeira está associada a uma condição de virilidade, de demonstração da força e da valentia masculinas. A coragem quando associada às feminilidades teve o caráter de força de vontade, determinação.

Outra característica considerada inerente à legitimação dos papéis de gênero encontrada com freqüência foi o "Respeito". Obtivemos 77 menções a esta propriedade, sendo que, 57 delas se direcionaram, especificamente, ao papel da mulher. Os resultados nos levam a afirmar que, no entender dos jovens participantes de nossa investigação, o "Respeito" é uma qualidade mais exigida das mulheres que dos homens. Além desta tendência parece-nos relevante apontar que também o "Respeito" teve significativas evidências de ser assumido com um sentido bastante distinto quando direcionado, a homens ou, a mulheres. O "Respeito" masculino foi um "Respeito" social, público, de gentileza, de deferência perante os outros; é quase sempre direcionado a alguém. O "Respeito" feminino, por sua vez, foi associado à instância do privado, do recato, do pudor; é um "Respeito" voltado para si mesmo.

A última referência qualificativa que apresentamos é a "Responsabilidade"; mencionada 43 vezes, apresentou equivalência em seu direcionamento em relação ao "ser" ou "ter atitude de homem" ou ao "ser" ou "ter atitude de mulher" com 22 menções para as mulheres. Este atributo apresentou uma raiz comum, associada ao cumprimento de algo acordado entre as partes. No entanto, também a "Responsabilidade" demonstrou, intrinsecamente, certo sentido distinto quando aplicado ao homem ou à mulher. Quando deste tipo de ocorrência, a "Responsabilidade" masculina apresentou a conotação do provedor, daquele que assume o compromisso de manter e sustentar alguém, muito próximo do caráter do trabalhador quando das associações indiretas propostas anteriormente. A "Responsabilidade" feminina, por sua vez, está indiretamente associada ao trabalho doméstico, ao cuidado com os mais próximos, os filhos, o marido, etc. 


\section{3. ANÁLISE DOS MODELOS DA SEGUNDA FASE}

A esta altura da análise dedicamo-nos ao aprofundamento das afirmativas feitas pelos jovens, nas questões de 7 a 10 do formulário entregue, em cujas proposições pretendíamos identificar as representações dos jovens quando de um conflito de interesses entre pares.

As questões 7 e 8 apresentaram um embate entre parceiros de sexo oposto, sendo em primeira instância, o promotor um homem, seguido da situação inversa. As afirmativas incompletas de número 9 e 10, por sua vez, supunham um confronto entre pares de mesmo sexo, mais uma vez, iniciada a série pelo agente masculino, complementado pela agente feminina.

A primeira definição para a análise destas questões foi buscar identificar algo comum às lógicas aplicadas aos modelos de cada uma das questões. Esta iniciativa nos permitiu, posteriormente, confrontar as similaridades e as disparidades das percepções dos jovens em cada situação específica. Comparar os elementos inferidos a cada uma das hipóteses de conflito evidenciou as hierarquias de interesses, imputadas pelos participantes, às afirmações.

Em função das respostas obtidas foi possível distinguir dois agrupamentos distintos. $\mathrm{O}$ primeiro, "Grupo A", reuniu as respostas dos jovens que assumiram o partido de um dos envolvidos no conflito, grupo este que denominamos: “Com juízo de valor”. A outra parte, por sua vez, foi composta por aquelas respostas cujos sujeitos não evidenciaram tomar para si a defesa, ou a condenação, de nenhuma das partes. A este perfil, denominamos: "Sem juízo de valor", objeto da análise do "Grupo B”.

O “Grupo A” - com juízo de valor - gerou, também, dois modelos.

O primeiro, "Modelo 1", justifica a agressão; o segundo, "Modelo 2", recrimina a agressão. A premissa que explica a defesa do agressor é uma suposta motivação pautada, predominantemente, na traição ou na decepção amorosa. O que sustenta a defesa do agredido, por sua vez, é a suposição de uma conduta recriminável ou a falta de habilidade do agressor em lidar com os próprios problemas. A tendência em assumir o partido do agressor é a marca do Modelo 1; a tendência a assumir a defesa do agredido, é o eixo do Modelo 2.

O “Grupo B”, dentro desta série, é aquele em que reunimos as afirmações dos jovens que não manifestaram, diretamente, um julgamento das hipóteses conflituosas propostas e foi denominado: "Sem juízo de valor", que também apresenta duas tendências centrais.

A lógica que sustentou o conflito motivado por sentimentos, por seu excesso ou pela falta, sem assumir diretamente a defesa de nenhum dos envolvidos, gerou o "Modelo 3". O raciocínio que pretendeu relacionar o embate a um problema de conduta de um dos 
envolvidos, enquanto argumento encontrado, sem justificá-lo ou recriminá-lo, é a origem do "Modelo 4".

Quando da aplicação dos modelos identificados a cada uma das questões desta segunda série de análise, é possível identificar algumas tendências gerais.

Especificamente em relação à "Sétima Questão", quando o agressor é do sexo masculino e a agredida do sexo feminino, predominam as justificativas pautadas na defesa do agressor, especialmente, aquelas associadas a uma possível decepção amorosa, com uma incidência maior entre os jovens do sexo masculino. Foi apenas nesta hipótese que surgiu a questão da "legítima defesa dos sentimentos" do agressor. Outra tendência marcante é a defesa da agredida pautada no questionamento moral do agredido, linha preferencialmente adotada pelas adolescentes do sexo feminino (Gráficos 19 e 20, página 128). As duas orientações somadas alcançam praticamente $70 \%$ das respostas obtidas. Evidencia-se, portanto que, na hipótese de um conflito de interesses envolvendo agressor/agredida é grande a tendência em assumir o partido de um dos personagens. Há pouco espaço para a imparcialidade.

A “Oitava Questão” apresentando um confronto, ainda, entre pares do sexo oposto, sendo, desta feita, o agente provocador do sexo feminino, evidenciou a tendência a ancorar as representações na defesa da agressora, novamente, mais pautada na traição, provocação ou decepção amorosa. No caso desta hipótese, agressora/agredido, há uma clara transferência da defesa do agredido para uma motivação assentada no sentimento de um dos envolvidos, pautada, especialmente, na hipótese da desconfiança em relação a um terceiro personagem inferido pelos adolescentes (Gráficos 21 e 22, página 135). A tendência à imparcialidade (Modelos 3 e 4 - 85 afirmações) se aproxima da tendência em assumir os interesses de um dos envolvidos como legítimos (Modelos 1 e 2 - 118 afirmações); são 42\% contra 58\%, respectivamente, com uma participação dos respondentes de ambos os sexos, de forma praticamente equivalente.

Evidencia-se na comparação entre as duas questões, 7 e 8, que ainda que com ligeira variação, é especialmente na defesa do(a) agressor(a) que os jovens pautaram as suas representações quando do conflito entre pares do sexo oposto (Gráficos 23 e 24, página 136), com ligeira variação ascendente quando o provocador era o personagem do sexo feminino. Alguns aspectos da comparação são relevantes, uma vez que há uma tendência crescente, de acordo com a idade, especialmente entre os jovens do sexo masculino, em justificar o conflito agressor/agredida a partir de uma inferência referendada na garantia da integridade emocional, ou moral, do agressor. Chama a atenção, ainda, o baixo índice de desmoralização 
do agredido em relação à agressora se comparado à condição inversa, agredida/agressor; foi encontrada apenas $1 / 4$ da representatividade da primeira hipótese em relação à segunda, ou seja, desqualifica-se quatro vezes mais a agredida frente ao agressor que o agredido frente à agressora.

A "Nona questão" apresentava um conflito entre dois homens. A inferência mais freqüente foi a de que houvesse um terceiro personagem gerando o confronto, Modelo 3. As posições de defesa (Modelo 1) ou acusação (Modelo 2) do agressor tiveram exatamente a mesma quantidade de afirmações (43 cada); as duas somadas (86) não chegaram ao total das afirmações obtidas para a primeira das inferências apontada, embate causado por convivência ou sentimento (94). É nesta questão que o Modelo 4, pautado na conduta inadequada de um dos envolvidos, especialmente relacionado ao vício (submodelo 4A) apresentou a maior quantidade de complementações obtidas. Não houve diferenças significativas na representatividade dos respondentes do sexo masculino ou feminino, exceção feita ao Modelo 2, a partir de uma percepção das jovens de ter sido motivado o conflito por uma conduta tipicamente masculina, relacionada ao abuso das prerrogativas do "macho" (Gráficos 25 e 26, página 143).

A "Décima questão" apresentou a iminência de um conflito entre mulheres. Prevaleceu a inferência da disputa, ou desconfiança, em relação à participação de um terceiro personagem (Modelo 3). A soma das demais alternativas (Modelos 1, 2 e 4) assume representatividade equivalente nas afirmações obtidas em relação à associação com os ciúmes de um dos envolvidos. Evidencia-se que as tendências a um modelo, ou outro, tem desempenho muito próximo frente às afirmativas obtidas das jovens ou dos jovens (Gráficos 27 e 28 , página 150$)$.

$\mathrm{Na}$ comparação entre os modelos aplicados pelos adolescentes às duas questões envolvendo personagens do mesmo sexo, é possível verificar que há pouca variação nas principais inferências (Gráficos 29 e 30, página 151). Fica claro que, as garotas e os garotos, optam mais pela imparcialidade (Modelos 3 e 4) em tais circunstâncias; assumem menos a inocência ou a culpa de um dos envolvidos (Modelos 1 e 2). Entretanto, aprofundando a análise apenas nos aspectos que apresentaram alguma variação, destaca-se o fato de que quando houve a responsabilização do agressor (submodelo 1C) em conflitos entre pares do mesmo sexo, houve uma tendência maior a justificar a mulher agressora, 33 afirmações obtidas defendendo a mulher contra apenas 20 defendendo o homem. Em sendo os pares a se desentenderem do mesmo sexo, o homem mereceu maior recriminação pela contenda; foram especialmente as adolescentes, notadamente as mais jovens, que marcaram tal inclinação. 


\section{PRIMEIRA FASE DA ANÁLISE DE DADOS}

\begin{tabular}{|c|c|c|c|c|c|c|c|c|c|c|c|c|c|c|c|c|c|c|c|c|}
\hline \multirow{3}{*}{ Questões } & \multicolumn{8}{|c|}{ Associação Indireta } & \multicolumn{12}{|c|}{ Associação Direta } \\
\hline & \multirow{2}{*}{\multicolumn{4}{|c|}{$\begin{array}{c}\text { Modelo 1 } \\
\text { Trabalho } \\
\end{array}$}} & \multicolumn{4}{|c|}{ Modelo 2} & \multicolumn{4}{|c|}{ Modelo 3} & \multicolumn{4}{|c|}{ Modelo 4} & \multicolumn{4}{|c|}{ Modelo 5} \\
\hline & & & & & \multicolumn{4}{|c|}{ Virtude } & \multicolumn{4}{|c|}{ Sexo } & \multicolumn{4}{|c|}{ Sexualidade } & \multicolumn{4}{|c|}{ Gênero } \\
\hline $\begin{array}{l}\mathbf{1}-\mathbf{2}-\mathbf{3}-\mathbf{4}-\mathbf{5}-\mathbf{6} \\
\text { 1) Homem que é homem }\end{array}$ & \multicolumn{4}{|c|}{36} & \multicolumn{4}{|c|}{43} & \multicolumn{4}{|c|}{81} & \multicolumn{4}{|c|}{2} & \multicolumn{4}{|c|}{45} \\
\hline 2) Mulher que é mulher é: & \multicolumn{2}{|c|}{$\mathrm{F}$} & \multicolumn{2}{|c|}{$\mathrm{M}$} & \multicolumn{2}{|c|}{$\mathrm{F}$} & \multicolumn{2}{|c|}{$\mathrm{M}$} & \multicolumn{2}{|c|}{$\mathrm{F}$} & \multicolumn{2}{|c|}{$\mathrm{M}$} & \multicolumn{2}{|c|}{$\mathrm{F}$} & \multicolumn{2}{|c|}{$\mathrm{M}$} & \multicolumn{2}{|c|}{$\mathrm{F}$} & \multicolumn{2}{|c|}{ M } \\
\hline 4) Mulher só é mulher se: & \multicolumn{2}{|c|}{18} & \multicolumn{2}{|c|}{18} & \multicolumn{2}{|c|}{22} & \multicolumn{2}{|c|}{21} & \multicolumn{2}{|c|}{41} & \multicolumn{2}{|c|}{40} & \multicolumn{2}{|c|}{0} & \multicolumn{2}{|c|}{2} & 1 & & & \\
\hline tem que: & $\mathrm{S}$ & $\mathrm{C}$ & $\mathrm{S}$ & $\mathrm{C}$ & $\mathrm{S}$ & $\mathrm{C}$ & $\mathrm{S}$ & $\mathrm{C}$ & $\mathrm{S}$ & $\mathrm{C}$ & $\mathrm{S}$ & $\mathrm{C}$ & $\mathrm{S}$ & $\mathrm{C}$ & $\mathrm{S}$ & $\mathrm{C}$ & $\mathrm{S}$ & $\mathrm{C}$ & $\mathrm{S}$ & $\mathrm{C}$ \\
\hline $\begin{array}{l}\text { 7) Toda mulher para ser mulher } \\
\text { tem que: }\end{array}$ & 11 & 7 & 9 & 9 & 14 & 8 & 5 & 14 & 29 & 12 & 17 & 23 & 0 & 0 & 0 & 2 & 11 & 4 & 17 & 13 \\
\hline
\end{tabular}

\begin{tabular}{|c|c|c|c|c|c|c|c|}
\hline \multicolumn{8}{|c|}{ ANÁLISE COMPLEMENTAR DA } \\
\hline & & \multicolumn{6}{|c|}{ Adjetivação Hierarquizada } \\
\hline & & \multicolumn{2}{|c|}{ Coragem } & \multicolumn{2}{|c|}{ Respeito } & \multicolumn{2}{|c|}{ Responsabilidade } \\
\hline \multirow{2}{*}{ Questão 1} & \multirow{2}{*}{$\begin{array}{l}\text { Homem que é } \\
\text { homem é: }\end{array}$} & \multicolumn{2}{|c|}{34} & \multicolumn{2}{|c|}{2} & \multicolumn{2}{|c|}{7} \\
\hline & & F: 16 & M: 18 & $\mathrm{~F}: 2$ & M: 0 & F: 4 & M: 3 \\
\hline \multirow{2}{*}{ Questão 2} & \multirow{2}{*}{$\begin{array}{l}\text { Mulher que é } \\
\text { mulher é: }\end{array}$} & \multicolumn{2}{|c|}{16} & \multicolumn{2}{|c|}{16} & \multicolumn{2}{|c|}{$\mathbf{0}$} \\
\hline & & F: 14 & M: 2 & F: 6 & M: 10 & $\mathrm{~F}: 0$ & M: 0 \\
\hline \multirow{2}{*}{ Questão 3} & \multirow{2}{*}{$\begin{array}{l}\text { Homem só é } \\
\text { homem se: }\end{array}$} & \multicolumn{2}{|c|}{22} & \multicolumn{2}{|c|}{7} & \multicolumn{2}{|c|}{10} \\
\hline & & $\mathrm{F}: 12$ & M: 10 & $\mathrm{~F}: 4$ & M: 3 & F: 8 & M: 2 \\
\hline \multirow{2}{*}{ Questão 4} & \multirow{2}{*}{$\begin{array}{l}\text { Mulher só é } \\
\text { mulher se: }\end{array}$} & \multicolumn{2}{|c|}{15} & \multicolumn{2}{|c|}{23} & \multicolumn{2}{|c|}{9} \\
\hline & & $\mathrm{F}: 11$ & M: 4 & F: 16 & M: 7 & $\mathrm{~F}: 4$ & M: 5 \\
\hline \multirow{2}{*}{ Questão 5} & \multirow{2}{*}{$\begin{array}{l}\text { Todo homem } \\
\text { p/ ser homem } \\
\text { tem que: }\end{array}$} & \multicolumn{2}{|c|}{21} & \multicolumn{2}{|c|}{11} & \multicolumn{2}{|c|}{4} \\
\hline & & F: 11 & M: 10 & $\mathrm{~F}: 6$ & M: 5 & $\mathrm{~F}: 3$ & M: 1 \\
\hline \multirow{2}{*}{ Questão 6} & \multirow{2}{*}{$\begin{array}{l}\text { Toda mulher p/ } \\
\text { ser mulher tem } \\
\text { que: }\end{array}$} & \multicolumn{2}{|c|}{5} & \multicolumn{2}{|c|}{18} & \multicolumn{2}{|c|}{13} \\
\hline & & $\mathrm{F}: 3$ & M: 2 & $\mathrm{~F}: 13$ & M: 5 & F: 10 & M: 3 \\
\hline
\end{tabular}

\begin{tabular}{|c|c|c|c|c|c|c|c|c|c|}
\hline \multicolumn{10}{|c|}{ SEGUNDA FASE DA ANÁLISE DE DADOS } \\
\hline & & \multicolumn{4}{|c|}{ Com juízo de valor } & \multicolumn{4}{|c|}{ Sem juízo de valor } \\
\hline & & \multirow{2}{*}{\multicolumn{2}{|c|}{$\begin{array}{c}\text { Modelo 1 } \\
\text { Assume o } \\
\text { partido do(a) } \\
\text { agressor(a) } \\
\end{array}$}} & \multicolumn{2}{|c|}{ Modelo 2} & \multicolumn{2}{|c|}{ Modelo 3} & \multicolumn{2}{|c|}{ Modelo 4} \\
\hline & & & & $\begin{array}{r}\text { Ass } \\
\text { partic } \\
\text { agre }\end{array}$ & $\begin{array}{l}\text { ne o } \\
\text { do(a) } \\
\text { do(a) }\end{array}$ & $\begin{array}{r}\text { Co } \\
\text { motiv } \\
\text { sent }\end{array}$ & $\begin{array}{l}\text { lito } \\
\text { lo por } \\
\text { tento }\end{array}$ & $\begin{array}{r}\text { Mot } \\
\mathrm{cc} \\
\mathrm{im}\end{array}$ & $\begin{array}{l}\text { lo por } \\
\text { uta } \\
\text { pria }\end{array}$ \\
\hline \multirow[t]{2}{*}{ Questão 7} & \multirow{2}{*}{$\begin{array}{l}\text { Homem quando } \\
\text { briga com mulher } \\
\text { é porque... }\end{array}$} & \multicolumn{2}{|c|}{84} & \multicolumn{2}{|c|}{62} & \multicolumn{2}{|c|}{46} & \multicolumn{2}{|c|}{13} \\
\hline & & F: 29 & M: 55 & F: 43 & M: 19 & F: 25 & M: 21 & F: 5 & M: 8 \\
\hline \multirow[t]{2}{*}{ Questão 8} & \multirow{2}{*}{$\begin{array}{l}\text { Mulher quando } \\
\text { briga com homem } \\
\text { é porque... }\end{array}$} & \multicolumn{2}{|c|}{93} & \multicolumn{2}{|c|}{25} & \multicolumn{2}{|c|}{71} & \multicolumn{2}{|c|}{14} \\
\hline & & F: 45 & M: 48 & F: 13 & M: 12 & F: 36 & M: 35 & F: 9 & M: 5 \\
\hline \multirow[t]{2}{*}{ Questão 9} & \multirow{2}{*}{$\begin{array}{l}\text { Homem quando } \\
\text { briga com homem } \\
\text { é porque... }\end{array}$} & \multicolumn{2}{|c|}{43} & \multicolumn{2}{|c|}{43} & \multicolumn{2}{|c|}{94} & \multicolumn{2}{|c|}{27} \\
\hline & & F: 20 & M: 23 & F: 26 & M: 17 & F: 43 & M: 51 & F: 13 & M: 14 \\
\hline \multirow[t]{2}{*}{ Questão 10} & \multirow{2}{*}{$\begin{array}{l}\text { Mulher quando } \\
\text { briga com mulher } \\
\text { é porque... }\end{array}$} & \multicolumn{2}{|c|}{51} & \multicolumn{2}{|c|}{26} & \multicolumn{2}{|c|}{102} & \multicolumn{2}{|c|}{26} \\
\hline & & F: 20 & M: 31 & F: 14 & M: 12 & F: 52 & M: 50 & F: 16 & M: 10 \\
\hline
\end{tabular}




\section{CONSIDERAÇÕES FINAIS}

O percurso que deu início ao presente trabalho foi, em parte, a minha convicção pessoal de que a Educação praticada nas instituições formadoras das novas gerações e, especialmente em nossas unidades escolares, deva tomar para si parte da responsabilidade de construirmos um projeto de mundo coletivo que seja coerente com aquele que, em nossos sonhos individuais mais ousados, almejamos e desejamos para nós mesmos.

Particularmente acredito que, por hora, sejamos, ainda, muito mais eficientes em nossos discursos que em nossas práticas e que continuemos, de algum modo, crendo firmemente que algum líder "iluminado" ou algum "evento sobrenatural" possa nos trazer "de graça" e "por graça" o mundo que queremos. Esquecemo-nos, com freqüência, daquele quinhão que compete a cada um de nós. De arregaçar as próprias mangas e contribuir, como possamos, para buscar a eqüidade e a igualdade entre os semelhantes. Se não nos é possível, ainda, fazê-lo indistintamente, que o façamos equilibradamente, como educadores, no microcosmo em que atuamos.

Um espaço para a manifestação das subjetividades sem distinções e sem discriminações; ambiente propício para a convivência harmoniosa e pacífica de sujeitos que se reconheçam reciprocamente considerando legítimos seus direitos, deveres, sentimentos, afetos e emoções independentemente de suas origens, raízes, categorias, tendências ou opções...

Como afirmamos anteriormente, este é um trabalho, cuja origem se remete, de algum modo, a um diálogo de mim para comigo mesma, e as reflexões que o geraram são uma forma de reconhecer o distanciamento criado pelos meus devaneios idealistas e as escolhas que tenho feito em meu cotidiano.

Aspira-se que a Ciência - e em nosso caso, mais especificamente a Educação, - deva estar, de algum modo, a serviço da humanidade. Em função disto, o percurso traçado, pretendeu apontar subsídios para com as possibilidades de intercâmbio entre as subjetividades e as coletividades, pautando-se em referenciais que possam sinalizar uma trajetória, dentre as infinitas possibilidades, por intermédio de interações e relações, suficientemente satisfatórias para gerar o bem-estar e o "bem viver" coletivos. Analisando, uma, entre as infinitas interações e relações que se estabelecem entre as "partes" e o "todo", acreditamos ter sido possível contribuir para apontar caminhos buscando promover uma convivência mais equilibrada e pacífica. 
Se é fato que queiramos mesmo alcançar, individual ou coletivamente, a "tal felicidade" - como penso - essa busca ontológica continua a promover verdadeiros prodígios.

Essa foi uma das perspectivas que direcionou o início de nossos trabalhos.

Como ponto de partida, buscamos respaldar nossas reflexões nas leituras de Aristótles e Kant que pretenderam construir uma fundamentação racional da busca da felicidade transcendendo a instância do individualismo. De diferentes maneiras defendem que uma ação individual, refletida, possa se transformar em uma ética universal pautada por princípios inalienáveis. Entendem que uma ação reflexiva gere a ética, que não é meramente prescritiva, mas fruto de uma conscientização dos valores do próprio indivíduo. No binômio felicidade/moralidade, defendem os autores, que os fins de todas as nossas ações devam ter por orientação a felicidade e o bem humanos.

A mesma orientação leva Kohlberg e Piaget a investigar as raízes da moralidade humana. Os teóricos almejavam descobrir uma trajetória que pudesse ser percorrida buscando garantir que todos os sujeitos viessem a agir eticamente. Em seus estudos pretenderam desvendar estágios de desenvolvimento moral que, semelhante a um processo, pudessem gerar um "percurso", cujas prescrições promovessem uma ética ao alcance de todos. De um estágio heterônomo, suscetível às influências dos outros, das circunstâncias e do meio, à autonomia, alçando a independência e emancipação moral de interesses imediatos ou individualistas. Suas premissas pautaram-se no princípio da justiça levando-os a defender que agir com justiça é agir eticamente.

No esteio de tais pesquisas abriram-se brechas para discussões que apontaram outros princípios, para além da justiça, como norteadores da moralidade humana. De um preceito primordialmente construído a partir da dimensão da vida pública, Gilligan introduz o "care", ou cuidado, instância preponderantemente da vida privada. Benhabib, por sua vez, aponta a necessidade de considerar, para além do "outro generalizado", sujeito objeto da justiça, dos direitos e dos deveres, um "outro concreto", legitimado em sua manifestação singular, da instância dos seus desejos, dos seus sentimentos e dos seus afetos. Lévinas afirma a urgência de um "outro assumindo um rosto" defendendo uma ética menos abstrata. Campbell \& Christopher enriquecem a discussão apontando para a dicotomia, tipicamente ocidental, dos estudos da moralidade humana. Defendem a necessidade de transpormos a discussão de uma instância alternativa para uma instância conjuntiva.

A discussão acima deflagra questionamentos sobre outros tantos temas que envolvem a invisibilidade, de parte do(a)s esquecido(a)s ou silenciado(a)s em nossa caminhada histórica. Uma das questões que se afirma na esteira destas discussões são as relações de 
gênero. Gilligan, Scott, Nicholson entre outra(o)s tanta(os)s digna(o)s de menção, são alguma(n)s da(o)s precursora(e)s que alertam para a necessidade de incluir a perspectiva feminista em nossas análises. Sabemos hoje que, apenas "dicotomizar", incluindo o feminino na perspectiva da humanidade, não é suficiente para dar conta da igualdade e de equidade. A questão é muito mais complexa e exige que estejamos atentos às sutilezas e nuances intrínsecas às relações "intra" e "inter" pessoais no contexto das subjetividades e da coletividade de forma mais abrangente.

Recuperando a promessa filogenética da felicidade para todos, mulheres e homens, indistintamente, procuramos encontrar referenciais que pudessem atentar para a diversidade, das manifestações dos sujeitos participantes de nossa investigação, sem estabelecer critérios e/ou categorias fixas anteriores aos resultados obtidos.

A partir, portanto, de nossas reflexões, buscamos nos pressupostos dos modelos organizadores de pensamento um percurso que pudesse nos orientar a encontrar algumas evidências sobre as formas como os jovens interpretam as variáveis de gênero a partir de sua leitura própria de mundo, permeada, de forma mais ou menos significativa, pelas crenças e valores construídos sócio-culturalmente, especialmente quando da legitimação de seus papéis sociais enquanto feminilidades e masculinidades em construção.

Subsidiados pelas análises feitas a partir das idéias centrais identificadas nas lógicas que nortearam o julgamento feito pelos adolescentes às afirmações/situações propostas - aqui denominados "modelos"-, entendemos que tenhamos encontrado evidências de que efetivamente há, em suas representações, uma forma hierárquica de legitimação, senão diretamente para os papéis, denunciada por atributos associados a eles.

Algumas de nossas constatações merecem atenção. A legitimação social associada ao trabalho, apontada especialmente pelos jovens do sexo masculino da faixa etária inicial de nosso recorte, demonstrou que tal atributo é referendado, majoritariamente, no homem, que, no entanto, não estabelece hierarquia nas interações de gênero. As qualidades da condição humana, acima das variáveis de gênero, ou "virtudes", foram a opção predominantemente apontada pelas jovens, que também não evidenciaram uma subordinação nos atributos. As mulheres, para serem legitimadas em seu papel social, demandaram em maior número de atributos múltiplos, ou seja, de mais de uma "qualidade" para o seu reconhecimento. Variáveis associadas diretamente à condição biológica, sua individualização, ou à sua leitura a partir de construções sócio-históricas, apontaram as mais significativas valorações distintas entre os papéis feminino e masculino, especialmente entre os jovens do sexo masculino a 
partir dos treze anos. "Qualificações" intrínsecas, associadas aos papéis, evidenciaram uma clara distinção de significado quando associado às masculinidades ou às feminilidades.

$\mathrm{Na}$ segunda série de questionamentos evidenciou-se que o sexo do agente agressor intervem significativamente nas inferências feitas pelos adolescentes. Os jovens entenderam que o desentendimento entre pares do mesmo sexo possa ser "natural" a uma relação interpessoal. Quando de sexo oposto, os respondentes tiveram uma tendência maior em assumir a defesa de uma das partes. Comparando as respostas obtidas nas duas hipóteses, em sendo o agente promotor do conflito, um agressor ou uma agressora, foi notável a discrepância na responsabilização do confronto. Na hipótese do agressor do sexo masculino, parece haver uma disposição relevantemente mais significativa, em interpretar a situação como sendo de responsabilidade da própria agredida, desqualificando-a moralmente. As afirmações obtidas parecem reforçar a hipótese de que haja, de fato, uma tendência maior a desmerecer a mulher quando do embate entre pares de sexo oposto.

A partir do que nos possível analisar, podemos inferir que um dos fatores que contribui para a manutenção de relações hierarquizadas, para muito além das de gênero, legitimando a subordinação de uns perante outros, tem de fato um viés na submissão dos interesses femininos aos masculinos, com uma de suas variáveis estreitamente vinculada a determinantes de ordem moral, que no cotidiano dessas subjetividades se transformam em recomendações e prescrições moralistas sustentando uma das possíveis formas de subjugação.

A uma de nossas questões iniciais, se, de fato, "A perspectiva androcêntrica que institui uma organização social bipolar, de extremos hierarquizados, estaria de fato presente nas representações sociais dos papéis de gênero, entre adolescentes, permitindo a desvalorização do elemento feminino?" respondemos que esta lógica ainda se sustenta na atualidade, de alguma forma, na maneira subliminar com que são feitas algumas das prescrições, pelos próprios jovens, a partir de suas inferências especialmente quando de suas adjetivações hierarquizadas, muito mais marcantes a partir dos treze anos, e, predominantemente, entre os garotos.

A pergunta subseqüente que nos fazíamos - "Uma vez identificada/respondida esta questão seria possível que as próprias meninas estivessem assumindo, como legítima, uma visão de mundo subordinada aos interesses masculinos? -, entendemos que os dados obtidos apontam para indícios de uma adaptação gradativa das feminilidades aos interesses das masculinidades, ao que inferimos que, ao assumir o papel de uma mulher, na coletividade muitas jovens ainda o façam ajustando-se às expectativas pautadas em uma valoração distinta daquilo que significa ser homem ou ser mulher. O fenômeno já identificado anteriormente, em 
outra pesquisa, demonstra-se crescente em função da faixa etária, o que equivale a dizer que, à medida que as jovens se reconhecem efetivamente como feminilidades, parecem adotar alguns dos pressupostos das relações de gênero tradicionalmente hierarquizadas. Tendem a assumir como legítima, prioritariamente, a defesa do elemento masculino ainda que à custa dos próprios interesses ou de sua própria desqualificação.

Propusemo-nos, ainda, a trilhar em nossa investigação um percurso que pudesse nos indicar "O que gera a ruptura da igualdade "natural" que existe entre meninos e meninas na infância?", fenômeno que se evidenciou a partir da comparação entre as respostas dadas, tanto por rapazes quanto por moças, nos dois extremos do recorte que adotamos para a nossa pesquisa de campo. Enquanto aos onze anos os jovens apontavam com maior freqüência valores indistintos, pautados na excelência humana, de forma independente e sem associações que priorizavam os atributos de um ou de outro papel, quanto mais se aproximavam dos quinze anos, maior a incidência de atributos valorativos, claramente hierarquizados. Vale ressaltar que tal fato foi identificado tanto na amostra feminina como na masculina, ainda que com uma incidência significativamente superior entre os adolescentes do sexo masculino. É possível admitir que haja, durante a puberdade, uma interação entre as transformações orgânicas que ocorrem e a significação cultural que lhes é atribuída.

Ao nos perguntarmos se: "Existem de fato modelos patriarcais ou outras formas hierárquicas de subordinação sendo naturalizados e banalizados?" assumimos que a partir da análise dos dados obtidos possamos afirmar que, ainda que muito já se tenha conquistado, ainda há milhares de subjetividades em constituição, vivenciando condições de vulnerabilidade social que a(o)s expõem a adversidades de toda ordem e que ameaçam a construção de sua subjetividade de forma saudável e equilibrada, garantindo-lhes a conscientização quanto aos fatores que os levam a banalizar as disparidades que os afetam.

Sem o caráter de privilégios para esta ou aquela forma de legitimar qualquer um dos papéis reafirmamos que a violência física, moral ou psíquica, continua sendo praticada ao expormos nossas crianças e nossos jovens a valores ultrapassados, para os quais nós mesmos não encontramos respostas, sem oferecer a contrapartida de uma educação pautada na reflexão e conscientização constantes das nossas possibilidades humanas.

Se de fato desejamos um mundo constituído por sujeitos morais, éticos e autônomos, cabe-nos tentar desvelar as variáveis que ainda sustentam lógicas de dominação e de subordinação.

Se esperamos que as futuras gerações estejam aptas a vivenciar relações mais equilibradas de si para consigo mesmos, para com os demais, a coletividade e o planeta urge 
que tenhamos em mente que qualquer fator que possa ameaçar tal construção deva ser denunciada.

Como esperar autonomia dos sujeitos se as premissas e perspectivas a partir das quais constroem a sua visão de mundo estão pautadas em princípios tão distantes? Se de fato, o respeito (mútuo) é condição inalienável, como defendia Piaget, para a constituição de sujeitos moralmente éticos, é lícito imaginar que esta autonomia possa ser distinta para homens e para mulheres?

Como vimos, por intermédio dos dados obtidos, as prescrições de valores para as feminilidades e as masculinidades têm direcionamento distinto. Coragem, responsabilidade e especialmente o respeito demonstraram conotações bem diversas quando associados aos homens e às mulheres.

Se homens e mulheres devam ter garantidas condições dignas a legitimá-los como sujeitos na coletividade esse é um desafio que se nos coloca... Respeito mútuo, reciprocidade, pactos e acordos demandam de autonomia de sujeitos que se reconheçam e se percebam como tal... 


\section{REFERÊNCIAS BIBLIOGRÁFICAS}

ADORNO, Sérgio. (1994). O social em uma era de incertezas. In: Dinâmicas multiculturais: novas faces, outros olhares. Actas das sessões plenárias do III Congresso Luso-Afro-Brasileiro de Ciências Sociais. Lisboa: Instituto de Ciências Sociais da Universidade de Lisboa.

ARANTES, Valéria Amorim. (2003) Afetividade, cognição e moralidade na perspectiva dos modelos organizadores de pensamento. In: ARANTES, Valéria Amorim (org). Afetividade na escola: alternativas teóricas e práticas. São Paulo: Summus, p 109-128.

ARANTES, Valéria Amorim. (2000) Cognição, afetividade e moralidade. In: Revista Educação e Pesquisa. São Paulo: FEUSP, v. 26, n. 2, jul/dez, p. 137-153.

ARANTES, Valéria Amorim. (2000) Estados de ânimo e os modelos organizadores de pensamento: um estudo exploratório sobre a resolução de conflitos morais. Tese de Doutorado. Barcelona: Facultat de Psicologia - Universitat de Barcelona.

ARANTES, Valéria Amorim. (2004) Gênero e sexualidade: a construção histórico-social dos sexos. In: PEC Formação Universitária. São Paulo: Imprensa Oficial, volume 6.

ARAÚJO, Ulisses Ferreira. (1996a). O ambiente escolar e o desenvolvimento do juízo moral infantil. In: PIAGET, Jean. MENIN, Maria Suzana de Stefano. ARAÚJO, Ulisses Ferreira. De LA TAILlE, Yves. MACEDO, Lino (org.). In: Cinco Estudos de Educação Moral. São Paulo: Casa do Psicólogo, p. 105-135.

ARAÚJO, Ulisses F. (1999). Conto de escola: a vergonha como regulador moral. São Paulo: Moderna.

ARAÚJO, Ulisses F. (2002). A construção de escolas democráticas: histórias sobre complexidade, mudanças e resistências. São Paulo: Moderna.

ARAÚJO, Ulisses F. (2007). A construção social e psicológica dos valores. In: ARANTES, Valéria Amorim (org). Educação e valores. São Paulo: Summus Editorial, p. 17-64.

ARAÚJO, Ulisses F. (2003a). A dimensão afetiva da psique humana e a educação em valores. In: ARANTES, Valeria Amorim (org). Afetividade na escola: alternativas teóricas e práticas. São Paulo: Summus Editorial, p. 153-170.

ARAÚJO, Ulisses Ferreira. (1996b). Moralidade e indisciplina: uma leitura possível a partir do referencial piagetiano. In: GROPPA AQUINO, Julio (org). Indisciplina na escola: alternativas teóricas e práticas. São Paulo: Summus Editorial, p. 103-115.

ARAÚJO, Ulisses Ferreira. (2003b). Temas transversais e a estratégia de projetos. São Paulo: Moderna.

ARENDT, Hannah. (2005a). A condição humana. Rio de Janeiro: Forense Universitária.

ARENDT, Hannah. (2005b). A crise na educação. In: ARENDT, Hannah. Entre o passado e o futuro. São Paulo: Perspectiva, p. 221-247. 
ARENDT, Hannah. (2004). Responsabilidade e Julgamento. São Paulo: Companhia das Letras.

ARISTÓTELES. (1973). Ética a Nicômaco. Tradução de Leonel Vallandro e Gerd Bornheim do original inglês de ROSÁ, W, D. São Paulo: Abril Cultural. Coleção: Os pensadores.

BANK, Barbara J. ed. (2007). Gender and education. An Encyclopedia. Volume one. Westport: PRAEGER, Sara Delament and Chaterine Marshall, Associate Editors.

BAUMAN, Zigmunt. (2001). A Modernidade Líquida. Rio de Janeiro: Jorge Zahar Editor.

BENHABIB, Seyla. (1992a). The generalized other and the concrete other: the KohlbergGilligan controversy and moral theory. In: BENHABIB, Seyla. Situating the self: gender, community and postmodernism in contemporary ethics. Cambridge: Polity Press, p. 148-171.

BENHABIB, Seyla. (1987). Outro generalizado e outro generalizado. In: BENHABIB, Seyla \& CORNELL, Drucilla (org). O feminismo como crítica da modernidade: releitura dos pensadores contemporâneos do ponto de vista da mulher. Rio de Janeiro: Rosa dos Tempos, p. 87-106.

BENHABIB, Seyla. (1992b). Una revisión del debate sobre las mujeres y la teoría moral. In: Isegória - Revista de Filosofia Moral y Política. Madrid: numero 6, p. 37-63.

BOVET, Magali. LEAL, Aurora. (2002) Conhecimento e mudança: os modelos organizadores na construção do conhecimento. São Paulo: Moderna.

BRANDÃO, Elaine Reis. HEILBORN, Maria Luiza. (2006) Sexualidade e gravidez na adolescência entre jovens de camadas médias do Rio de Janeiro, Brasil. In: Revista Cadernos de Saúde Pública. Rio de Janeiro: 22(7), julho 2006, p. 1421-1430.

BURNIER, Suzana Lana. (2006). O mundo do trabalho e a construção cultural de projetos de homem entre jovens favelados. In: DAYRELL, Juarez (org). Múltiplos olhares sobre educação e cultura. Belo Horizonte: UFMG, p. 137-165.

BUTLER, Judith. (2003). Tráfico sexual (entrevista). In: Cadernos Pagu. Campinas: Unicamp, n. 21, p. 157-209.

CAMPBELL, R. L. \& CHRISTOPHER, J. C. (1996). Moral development theory: a critique of this kantian pressupositions. In: Development Review, n.16, v.1, p. 1-47

CARVALHO, Marilia Pinto. (2008) Gênero na sala de aula: a questão do desempenho escolar. In: MOREIRA, Antonio Flavio. CANDAU, Vera Maria. Multiculturalismo: diferenças culturais e práticas pedagógicas. Petrópolis: Vozes, p. 90-124.

CASTELLS, Manuel. (2000). O fim do patriarcalismo: movimentos sociais, família e sexualidade na era da informação. In: O poder da Identidade - Volume II. Rio de Janeiro: Paz e Terra, p. 169-285. 
CHAKUR, Cilene Ribeiro de Sá Leite. (2005). Contributions from the psychogenetic research for the school education. In: Revista Psicologia Teoria e Pesquisa. Brasília: v. 21, n. 3. Disponível em:

http://www.scielo.br/scielo.php?script=sci arttext\&pid=S0102-37722005000300005\&lng=en\&nrm=iso

Acesso em: 01 de Agosto de 2007.

COMTE-SPONVILLE, André. (1996). Pequeno tratado das grandes virtudes. São Paulo: Martins Fontes.

CRAWFORD, Mary \& CHAFFIN, Roger. (1997). The meanings of difference: cognition in social and cultural context. In: CAPLAN, Paula. CRAWFORD, Mary. HYDE, Janet Shibley. RICHARDSON, John T. E. Gender differences in human cognition. New York, Oxford: Oxford University Press, p. 81-130.

CUNHA, Marcus Vinicius da. (1998). A psicologia na educação: dos paradigmas científicos às finalidades educacionais. Revista da Faculdade de Educação. São Paulo: USP, v. 24, n. 2. jul/dez. Disponível em:

http://www.scielo.br/scielo.php?script=sci_arttext\&pid=S0102-25551998000200004\&lng=en\&nrm=iso

Acesso em: 28 de Julho de 2007.

DAYRELL, Juarez (2003). O jovem como sujeito social. In: Revista Brasileira de Educação. Rio de Janeiro: n.24, dez., p. 40-52.

GOMES, Jerusa Vieira. (1996). Família, escola, trabalho: construindo desigualdades e identidades subalternas. Tese de Livre Docência. São Paulo: USP, Faculdade de Educação. Área de concentração: História e Filosofia da Educação. Defesa: 28 de Novembro de 1996.

GOMES, Jerusa Vieira. (1997). Jovens urbanos pobres. In: Revista Brasileira de Educação. Campinas: ANPED, n. 5/6, maio/dez, p. 53-62.

GOMES, Jerusa Vieira. (1998). Vida familiar e trabalho de crianças e de jovens pobres: considerações sobre o caso brasileiro. In: A criança e o adolescente no contexto das migrações São Paulo. São Paulo: Centro Scalabriano de estudos migratórios, p. 69-80.

GREGORI, Maria Filomena. (2003). Relações de violência e erotismo. In: Cadernos Pagu. Campinas: Unicamp, no. 20, p. 87-120.

Disponível em: http://www.scielo.br/pdf/cpa/n20/n20a03.pdf

Acesso em: 14 de Dezembro de 2007.

FROEMMING, Liliane Seide. (1999). De o eu é um outro a um outro eu: a amizade como laço social. In: Adolescência: entre o passado e o futuro. Porto Alegre: Artes \& Ofícios, p. 114-118.

GILLIGAN, Carol. (2003). Hearing the difference: Theorizing connection. In: Anuario de Psicología: Psicología y género. Barcelona: Paidós - Universidad de Barcelona/Facultat de Psicología. Vol 34, no. 2, junio, p. 155-161.

GILLIGAN, Carol. (1994). In a different voice. Cambridge, Massachussetts and London. England: Harvard University Press.

GILLIGAN, Carol. (1987). Moral orientation and moral development. In: KITTAY, E. F. \& MEYERS, D. T. Women and moral theory. New Jersey: Rowmand and Littlefield. 
GORDON, Tuula O. (2007). Social Constructionism. In: BANK, Barbara J. ed. (2007) Gender and education. An Encyclopedia. Volume one. Westport: PRAEGER, Sara Delament and Chaterine Marshall, Associate editors, p. 93-99.

GUBBA, Egon G. (1990). The alternative paradigm dialog. California: Sage Publications.

GUEDES, Simoni Lahud. (1997). Jogo de corpo. Niterói: Editora da Universidade Federal Fluminense.

HÉRITIER, Françoise. (1999). O eu, o outro e a tolerância. In: CHANGEAUX, Jean-Pierre (org). Uma ética para quantos? Bauru: EDUSC, p. 81-87.

INHELDER, Bärbel. (1996). Apresentação. In: INHELDER, Bärbel \& CELLÉRIER, Guy et al. $O$ desenrolar das descobertas da criança: um estudo sobre as microgêneses cognitivas. Porto Alegre: Artes Médicas, p.xi-xiv.

INHELDER, B. \& CAPRONA, D. (1996). Rumo ao construtivismo psicológico: estruturas? Procedimentos? Os dois indissociáveis. In: INHELDER, Bärbel \& CELLÉRIER, Guy et al. O desenrolar das descobertas da criança: um estudo sobre as microgêneses cognitivas. Porto Alegre: Artes Médicas, p. 7-37.

IZQUIERDO, Maria Jesús. (1994). Uso y abuso del concepto de gênero. In: VILANOVA, Mercedes (comp). Pensar las diferencias. Barcelona: Universitat de Barcelona/Institut Catalã de La Dona.

JERUSALINSKY, Alfredo et al. (1999). Apresentação. In: Adolescência: entre o passado e o futuro. Porto Alegre: Artes \& Ofícios, p. 7-9.

KANT, E. (1995). A paz perpétua e outros opúsculos. Lisboa: Edições.

KOYRÉ, Alexandre. (1991a). Galileu e Platão. In: Estudos de História do pensamento científico. Brasília: Forense, p. 152-179.

KOYRÉ, Alexandre. (1991b). O pensamento moderno. In: Estudos de História do pensamento científico. Brasília: Forense, p. 15-21.

De LA TAILlE, Yves. (2005a). Desenvolvimento do juízo moral. In: Revista Viver: mente \& cérebro. Coleção Memória da Pedagogia, no 1. São Paulo: Segmento - Duetto, p. 76-88.

De LA TAILlE, Yves. (1996). A educação moral: Kant e Piaget. In: PIAGET, Jean. MENIN, Maria Suzana de Stefano. ARAÚJO, Ulisses Ferreira. De LA TAILLE, Yves. MACEDO, Lino (org.). In: Cinco Estudos de Educação Moral. São Paulo: Casa do Psicólogo, p. $137-178$.

De LA TAILLE, Yves. (2005b). Moral e ética. Entrevista à equipe do centro de referências e documentação Mário Covas. Disponível em: www.crmaricovas.sp.gov.br Acesso em: 20 de Outubro de 2007.

De LA TAILlE, Yves. (2000). Para um estudo psicológico das virtudes morais. São Paulo: FEUSP, Revista Educação e Pesquisa, v.26, no. 2, p. 109-121. 
LEFFORT, Claude. (1999). Formação e autoridade: a educação humanista. In: Desafios da escrita política. São Paulo: Discurso Editorial

LEMOS de SOUZA, Leonardo. (2008a). Modelos organizadores, gênero e moral na resolução de conflitos entre jovens na escola. Tese de Doutorado. Campinas: Unicamp.

LEMOS de SOUZA, Leonardo. (2008b). Representações sobre os enfrentamentos à homofobia na escola por jovens de Mato Grosso e São Paulo. In (evento): Fazendo Gênero 8 - Simpósio temático: Corpo, violência e poder. Florianópolis: UFSC, 25 a 28 de agosto, p. $1-7$.

Disponível em:

www.fazendogenero8.ufsc.br/sts/ST20/Leonardo_Lemos_de_Souza20.pdf

Acesso em: 20 de Novembro de 2008.

LEMOS de SOUZA, Leonardo \& VASCONCELOS, Mário Sérgio. (2003). Modelos organizadores do pensamento: uma perspectiva de pesquisa sobre o raciocínio moral com adolescentes autores de infração. In: Revista Psicologia em Estudo. Maringá: v.8, no. 2, p. 47-59.

LEWIS, Michael. (1999). O progresso e a metáfora do desenvolvimento. In: Alterando o destino: por que o passado não prediz o futuro. Campinas: Unicamp \& Moderna, p. 05-118.

LOPES LOURO, Guacira. (1997a). A emergência do gênero. In: Gênero, sexualidade e educação. Petrópolis: Vozes, p. 14-36.

LOPES LOURO, Guacira. (1997c) Uma epistemologia feminista. In: LOPES LOURO, Guacira (org). Gênero, sexualidade e educação: uma perspectiva pós-estruturalista. Petrópolis: Vozes, p. 142-160.

LOPES LOURO, Guacira. (1997b). Gênero, sexualidade e poder. In: LOPES LOURO, Guacira (org). Gênero, sexualidade e educação: uma perspectiva pós-estruturalista.. Petrópolis: Vozes, p. 37-56.

LOPES LOURO, Guacira. (2004). Sexualidades contemporâneas: políticas de identidade e de pós-identidade. In: UZIEL, Anna Paula. RIOS, Luís Felipe. PARKER, Richard Guy. Construções da sexualidade: gênero, identidades e comportamento em tempos de aids. Rio de Janeiro: Pallas, p. 203-212.

MACHADO, Lia Zanotta. (2000). Perspectivas em confronto: relações de gênero ou patriarcado moderno? In (evento): Simpósio Relações de Gênero ou Patriarcado Contemporâneo, Sociedade Brasileira de Sociologia (Ed.), 52a . Reunião para o Progresso da Ciência (SBP). Brasília: UnB: Série Antropológica, n. 284, p. 1-20.

MADEIRA, Felícia Reicher. (1996a). Apresentação. In: MADEIRA, Felícia Reicher (org.). Quem mandou nascer mulher? Rio de Janeiro: Record, p. 7-10.

MADEIRA, Felícia Reicher. (1996b). Gênero, Cidadania e Adolescência. In: MADEIRA, Felícia Reicher. (org.). Quem mandou nascer mulher? Rio de Janeiro: Record, p. 15-43. 
MADEIRA, Felícia Reicher. (1996c). A trajetória das meninas dos setores popoulares: escola, trabalho... reclusão. In: MADEIRA, Felícia Reicher. (org.). Quem mandou nascer mulher? Rio de Janeiro: Record, p. 45-133.

MAYA, Beatriz Muñoz. (2005). Educar para a administração alternativa de conflitos como via de aprofundamento da Democracia. In: VINYAMATA, Eduard e col. Aprender a partir do conflito. Porto Alegre: Artmed, 75-83.

MENIN, Maria Suzana de Stefano. (1996). Desenvolvimento moral. In: PIAGET, Jean. MENIN, Maria Suzana de Stefano. ARAÚJO, Ulisses Ferreira. De LA TAILLE, Yves. MACEDO, Lino (org.). In: Cinco Estudos de Educação Moral. São Paulo: Casa do Psicólogo, p. 37-104.

MENIN, Maria Suzana de Stefano. (2002). Valores na escola. In: Revista Educação e Pesquisa. São Paulo: FEUSP, v. 28, n. 1, jan/jun, p. 91-100.

MILNITSKY-SAPIRO, Clary. (2006). A função da escola na construção de valores sócio morais: os temas transversais na cultura da descartabilidade. In (evento): Anais do I Congresso Internacional de Pedagogia Social. São Paulo: Faculdade de Educação, Universidade de São Paulo. Disponível em:

http://www.proceedings.scielo.br/scielo.php?script=sci arttext\&pid=MSC0000000092006000100008\&lng=en\&nrm=abn

Acesso em: 16 de Dezembro de 2007.

MONTENEGRO, Tereza. (2003). Diferenças de gênero e desenvolvimento moral das mulheres. In: Revista Estudos Feministas. Florianópolis: n. 11. Disponível em: http://www.scielo.br

Acesso em: 13 de Novembro de 2005.

MOORE, H. (1997). Compreendendo sexo e gênero. Tradução livre de Julio Assis Simões para uso didático do original Understanding sex and gender. In: Tim Ingold (ed) Companion Encyclopedia of Antropology. London: Routledge.

MOREIRA, Marco Antônio. (1997). Modelos mentais. Trabalho apresentado no: Encontro sobre teoria e pesquisa no ensino de Ciências: linguagem, cultura e cognição. Belo Horizonte: UFMG, Faculdade de Educação. 5 a 7 de março de 1997. Disponível em: www.if.ufrgs.br/ienci/artigos/Artigo_ID17/v1_n3 a1.pdf

Acesso em: 14 de Dezembro de 2008.

MORENO, Montserrat. (1999). Como se ensina a ser menina. São Paulo: Moderna.

MORENO MARIMÓN, Montserrat. (2002a). A psicologia cognitiva e os modelos mentais. In: MORENO, Montserrat. SASTRE, Genoveva. BOVET, Magali. LEAL, Aurora. Conhecimento e mudança: os modelos organizadores na construção do conhecimento. São Paulo: Moderna, p. 35-53.

MORENO MARIMÓN, Montserrat. (2002b). Uma teoria da mudança: os modelos organizadores. In: MORENO, Montserrat. SASTRE, Genoveva. BOVET, Magali. LEAL, Aurora. Conhecimento e mudança: os modelos organizadores na construção do conhecimento. São Paulo: Moderna, p. 73-102.

MORIN, Edgar. (1998). EI paradigma de complejidad. In: Introduccion al pensamiento complejo. Barcelona: Gedisa, p. 87-110. 
MORIN, Edgar. (1998). La inteligência ciega. In: Introduccion al pensamiento complejo. Barcelona: Gedisa, p. 27-35.

MOTT, Luiz. (1998). Teoria antropológica e sexualidade humana.

Disponível em: http://www.antropologia.ufba.br/artigos/teoria.pdf.

Acesso em: 14 de Dezembro de 2007.

NAJMANOVICH, Denise. (2001) A linguagem dos vínculos: da independência absoluta à autonomia relativa. In: $O$ sujeito encarnado: questões para pesquisa no/do cotidiano. Rio de Janeiro: DP\&A, p. 65-96.

NARVAZ, M. G. \& KOLLER, S. H. (2006). Famílias e patriarcado: da prescrição normativa à subversão criativa. In: Revista Psicologia \& Sociedade. Porto Alegre: UFRGS; volume 18(1) jan/abr, p. 49-55.

NEVES, Sofia; NOGUEIRA, Conceição. (2005). Feminist methodologies: reflexivity in social sciences research. In: Revista Psicologia, Reflexão e Crítica. Porto Alegre, v. 18, n. 3. Disponível em:

http://www.scielo.br/scielo.php?script=sci_arttext\&pid=S0102-79722005000300015\&lng=en\&nrm=iso.

Acesso em: 09 de Dezembro de 2007.

NEGUEIRA, Conceição. (2001). Contribuições do construcionismo social para uma nova psicologia de gênero. In: Cadernos de Pesquisa. São Paulo: n. 112, p. 137-153.

Disponível em:

http://www.scielo.br/scielo.php?script=sci_arttext\&pid=S0100-15742001000100007\&lng=en\&nrm=iso.

Acesso em: 09 de Dezembro de 2007.

NICHOLSON, Linda. (2000). Interpretando gênero. In: Revista Estudos Feministas. Florianópolis: CFH/CCE/UFSC, v.8, no. 2, p. 9-41.

OLIVER, Esther. \& VALLS, Rosa. (2004). Violencia de género. Barcelona: El Roure Editorial.

OLIVEIRA, João Manuel \& AMÂNCIO, Lígia. (2006). Teorias feministas e representações sociais: desafios dos conhecimentos situados para a psicologia social. In: Revista Estudos Feministas. Florianópolis: CFH/CCE/UFSC, v.14, no. 3, p. 597-615.

OLIVEIRA LIMA, Lauro. (1980). Piaget para principiantes. São Paulo: Summus Editorial.

PAIVA, Vera. (1999). Cenas sexuais, roteiros de gênero e sujeito sexual. In: BARBOSA \& PARKER. Sexualidades pelo avesso: direitos, identidades e poder. Rio: Relume-Dumará.

PARKER, Richard. (1999). Diversidade sexual, análise cultural e a Prevenção da AIDS. In: A construção da solidariedade: Aids, sexualidade e política no Brasil. Rio: RelumêDumará.

PARKER, Richard. (1991a). Homens e mulheres. In: PARKER, R. Corpos, prazeres e paixões: a cultura sexual no Brasil contemporâneo. São Paulo: Best Seller, p. 55-107.

PARKER, Richard. (1991b). Mitos de origem. In: PARKER, R. Corpos, prazeres e paixões: a cultura sexual no Brasil contemporâneo. São Paulo: Best Seller, p. 22-54. 
PIAGET, Jean. (2002). Epistemologia genética. São Paulo: Martins Fontes.

PIAGET, Jean. (1994). O juízo moral na criança. São Paulo: Summus Editorial.

PIAGET, Jean. (1996) Tradução: MENIN, Maria Suzana de Stefano. (1996). Os procedimentos da educação moral. In: PIAGET, Jean. MENIN, Maria Suzana de Stefano. ARAÚJO, Ulisses Ferreira. De LA TAILLE, Yves. MACEDO, Lino (org.). In: Cinco Estudos de Educação Moral. São Paulo: Casa do Psicólogo, p. 1-29.

PUIG, Josep Maria (1998). A construção da personalidade moral. São Paulo: Ática.

PUIG, Josep Maria (2004). Práticas morais: uma abordagem sociocultural da educação moral. São Paulo: Moderna.

QUELHAS , Ana Cristina. JUHOS, Csongor. SENOS, Jorge; et al. (1999). Desenvolvimento do raciocínio condicional e modelos mentais. In: Aná. Psicológica, dez, vol.17, no.4, p. 695-711.

RATTNER, Henrique. (2004). Sobre ética em tempos de barbárie. In: Revista Espaço Acadêmico. São Paulo: n. 39. Disponível em: www.espaçoacademico.com.br

Acesso em: 20 de outubro de 2005.

ROUANET, Sérgio Paulo. (1994). Iluminismo ou Barbárie. In: Mal-Estar na Modernidade. São Paulo: Companhia das Letras.

RUBIN, Gayle. (1999). Thinking sex: notes for a radical theory of politics of sexuality. In: PARKER \& AGGLETON. Culture, society and sexuality: a reader. London: Taylor \& Francis.

SAFFIOTI, Heleieth I. B. (2002). O poder do macho. São Paulo: Moderna.

SAFFIOTI, Heleieth I. B. (1992). Rearticulando gênero e classe social. In: COSTA, A. \& BRUSCHINI, C. (orgs.). Uma questão de gênero.Rio de Janeiro: Rosa dos Tempos.

SARTI, Cynthia Andersen. (1996). A família como espelho: um estudo sobre a moral dos pobres. Campinas: Autores associados.

SASTRE VILARRASA, Genoveva \& MORENO MARIMON, Montserrat. (2000). Nuevas perspectivas sobre el razionamento moral. Revista Educação e Pesquisa. São Paulo: FEUSP, v.26, no. 2, p. 123-135.

SASTRE, Genoveva \& MORENO, Montserrat. (2002). Resolução de conflitos e aprendizagem emocional. São Paulo: Moderna.

SCOTT, Joan Wallach. (2005). O enigma da igualdade. In: Revista Estudos Feministas. Florianópolis: CFH/CCE/UFSC, v.13, no. 1, p. 11-30.

SCOTT, Joan Wallach. (1995). Gênero: uma categoria útil de análise histórica. In: Revista Educação \& Realidade. v. 20, no. 2, jul./dez., 71-99. 
SILVA, Franklin Leopoldo e. (2001). O mundo vazio: sobre a ausência da política no contexto contemporâneo. In: SILVA, Doris Acioly \& MARRACH, Sonia Alem (orgs). Mauricio Tragtenberg. Uma vida para as Ciências Humanas. Araraquara: Unesp, p. 239-250.

SILVA, Maritza Maffei da. (1995). Mulher, identidade fragmentada. In: ROMERO, Elaine. (org.). Corpo, mulher e sociedade. Campinas: Papirus, p. 109-123.

STOCKARD, Jean. Sex Role Socialization. In: BANK, Barbara J. ed. (2007) Gender and education. An Encyclopedia. Volume one. Westport: PRAEGER, Sara Delament and Chaterine Marshall, Associate editors, p. 79-85.

TASSARA, Eda Terezinha de Oliveira. (2005). Environmental psychology and the future: geopolitical reflections on environmental policy. Revista Psicologia. São Paulo: USP, v. 16, n. 1-2. Disponível em:

http://www.scielo.br/scielo.php?script=sci arttext\&pid=S0103-65642005000100027\&lng=en\&nrm=iso

Acesso em: 31 de Julho de 2007.

TONATTO, Suzinara; SAPIRO, Clary Milnitsky. (2002). Os novos parâmetros curriculares das escolas brasileiras e educação sexual: uma proposta de intervenção em ciências. Revista Psicologia Social. Porto Alegre, v. 14, n. 2. Disponível em:

http://www.scielo.br/scielo.php?script=sci arttext\&pid=S0102-71822002000200009\&lng=pt\&nrm=iso.

Acesso em: 16 de Dezembro de 2007.

TOURAINE, Alain. (2006). Um novo paradigma: para compreender o mundo de hoje. Petrópolis: Vozes.

TRAVERSO-YÉPEZ, Martha A. PINHEIRO, Verônica de Souza. (2005) Socialização de gênero e adolescência. In: Revista Estudos Feministas. Florianópolis: CFH/CCE/UFSC, v.13, no. 1, p. 147-162.

VANCE, Carole. (1995). A antropologia redescobre a sexualidade: um comentário teórico. In: Physis - Revista de Saúde Coletiva. Rio de Janeiro: UERJ., v.5, n. 1, p. 7-31.

VIANNA, Claudia. (2003). Educação e gênero: parceria necessária para a qualidade do ensino. In: Gênero e educação: caderno para professores. São Paulo: Secretaria do Governo Municipal. Coordenadoria Especial da Mulher.

VÍCTORA, Ligia Gomes. (1999). Entre o céu e o inferno. In: Adolescência: entre o passado e o futuro. Porto Alegre: Artes \& Ofícios, p. 159-166.

WEEKS, Jefrey. (2001). O corpo e a sexualidade. In: LOURO, Guacira Lopes (org.). $O$ corpo educado: pedagogias das sexualidades. Belo Horizonte: Autêntica.

WELLER, Wivian. (2005). A presença feminina nas 9sub) culturas juvenis: a arte de se tornar visível. In: Revista de Estudos Feministas. Florianópolis: CFH/CCE/UFSC, v. 13, n. 1, abr, p. 107-126. Disponível em:

http://www.scielo.br/scielo.php?script=sci arttext\&pid=S0104-026X2005000100008\&lng=pt\&nrm=iso.

Acesso em: 03 de Novembro de 2008.

ZIZEK, Slavoj. (2003). A paixão pelo real. Folha de S. Paulo, Caderno Mais! 30 de novembro, p. 4-7. 